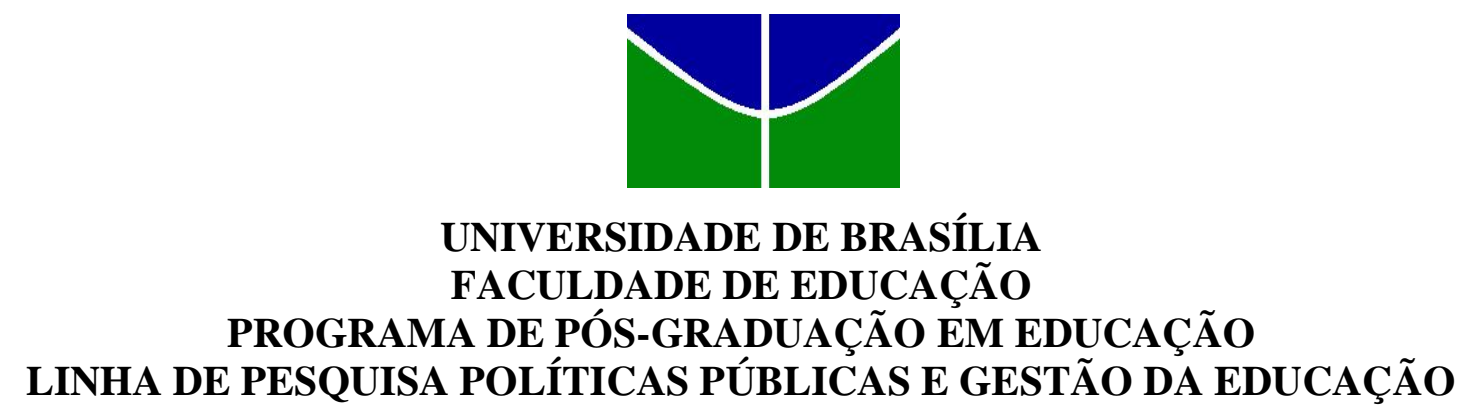

VALDINEI COSTA SOUZA

ENTRE O EXPLÍCITO E O LATENTE:

revelações do Parfor e do Sinaes sobre a qualidade dos cursos de pedagogia 



\section{VALDINEI COSTA SOUZA}

\section{ENTRE O EXPLÍCITO E O LATENTE:}

revelações do Parfor e do Sinaes sobre a qualidade dos cursos de pedagogia

Tese apresentada ao Programa de Pós-Graduação em Educação da Universidade de Brasília, vinculada à Linha de Pesquisa Políticas Públicas e Gestão da Educação, como requisito parcial para a obtenção do título de Doutora em Educação, sob a orientação do Prof. Dr. José Vieira de Sousa. 
Ficha catalográfica elaborada automaticamente, com os dados fornecidos pelo(a) autor(a)

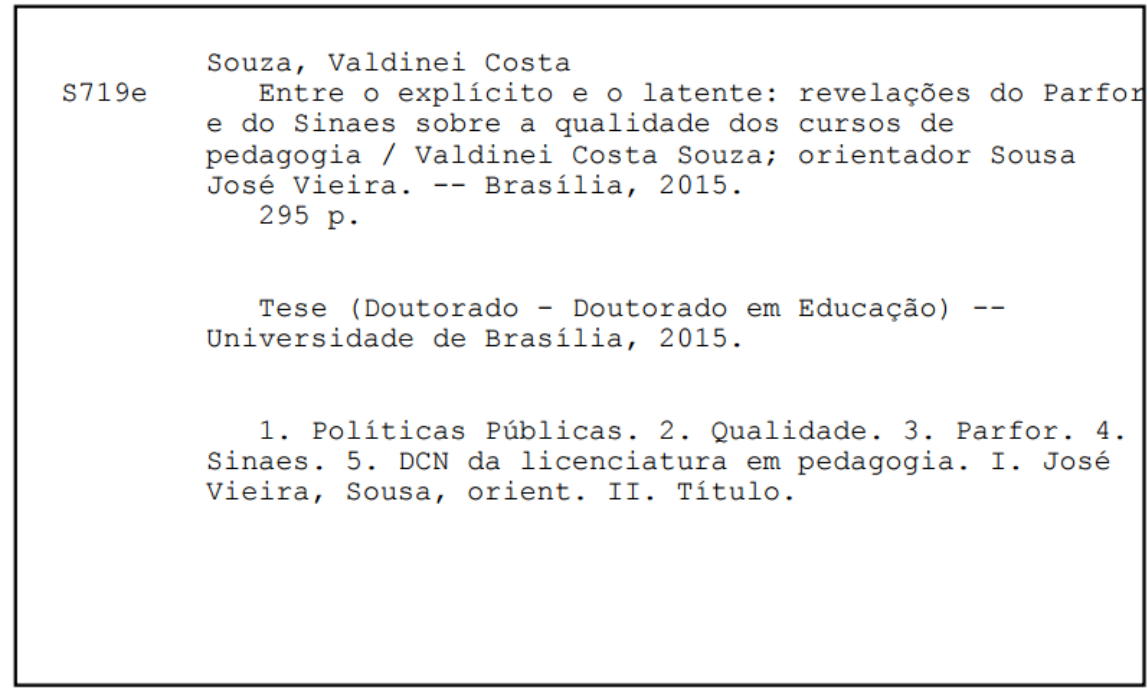




\title{
ENTRE O EXPLÍCITO E O LATENTE: \\ revelações do Parfor e do Sinaes sobre a qualidade dos cursos de pedagogia
}

\begin{abstract}
Tese apresentada ao Programa de Pós-Graduação em Educação da Universidade de Brasília, vinculada à Linha de Pesquisa Políticas Públicas e Gestão da Educação, como requisito parcial para a obtenção do título de Doutora em Educação, sob a orientação do Prof. Dr. José Vieira de Sousa.
\end{abstract}

Brasília, 17 de abril de 2015.

Banca Examinadora:

Prof. Dr. José Vieira de Sousa (Presidente)

Universidade de Brasília

Profa. Dra. Bernardete Angelina Gatti (Examinadora Externa)

Fundação Carlos Chagas

Profa. Dra. Katia Siqueira de Freitas (Examinadora Externa)

Universidade Católica de Salvador

Profa. Dra. Fernanda Antonia da Fonseca Sobral (Examinadora Externa)

Universidade de Brasília

Profa. Dra. Cleide Maria Quevedo Quixadá Viana (Examinadora)

Universidade de Brasília

Profa. Dra. Maria Abádia da Silva (Suplente)

Universidade de Brasília 

Aos meus filhos Davi e Vitor, razões da minha existência. 



\section{AGRADECIMENTOS}

A elaboração de uma tese pode ser comparada a uma jornada cheia de obstáculos, que somente foi possível ser cumprida graças ao apoio que recebi de pessoas muito solícitas e solidárias.

Assim, agradeço de todo coração:

Ao meu orientador, José Vieira de Sousa, incansável e comprometido em me ajudar a ampliar a consciência sobre os meus limites e, assim, ter oportunidade de tentar superá-los.

À professora Bernardete Gatti, pela inspiração que sempre encontrei em seus textos e pela gentileza que me oportunizou a honra de aproveitar presencialmente seus ensinamentos durante o estágio de doutorado (sanduíche).

Aos professores do PPGE, pelas conversas, ensinamentos e orientações. Destaco meu especial reconhecimento ao professor Bernardo Kipnis que me apresentou à obra de Georges Gurvitch e, de forma atenciosa e gentil, sempre se dispôs a conversar sobre pontos teóricos e operacionais da investigação todas as vezes que precisei.

Ao querido amigo Ricardo Lourenço, que me inspirou nas discussões sobre indicadores e parâmetros de qualidade, em meio às suas "tabelas coloridas" e análises "X9".

À Coordenação de Aperfeiçoamento de Pessoal de Nível Superior (Capes), pelo apoio à pesquisa por meio do Programa Institucional de Desenvolvimento de Recursos Humanos (PIDRH). Entre a solicitação de apoio e a sua concessão, foram fundamentais as participações de Geraldo Nunes Sobrinho, Celso Costa, Adi Balbinot, Alcir Souza, bem como as decisões da Comissão de Avaliação da Área de Educação, na pessoa da professora Elizabeth Macedo (UFRJ), que analisou o mérito do meu projeto de pesquisa, e, principalmente, da Diretoria Executiva da Capes, que aprovou o pleito.

Aos companheiros da Capes, que sempre estiveram presentes em cada uma das etapas desta Tese, a saber: no apoio ao longo do curso - Rômulo Barale, Gabriella Parisi, Izabel Siqueira, o Coordenador-Geral de Gestão de Pessoas, o Diretor de Gestão e o Diretor de Educação a Distância; no período de coleta de dados - Izabel Pessoa, Ninna Zamariolli, Sandra Cunha, Manoel Brod, Alexandre Martins e Gilmar Souza; nas 
conversas que me mantiveram conectada à instituição - Joana Abreu, Fernando Razuck, Pedro Roma, Fred Nepomuceno, Rose Cleide Monteiro e Auxiliadora Nicolato. Muitíssimo obrigada a todos pela cortesia e amizade.

Aos colegas do Grupo de Estudos sobre Políticas de Avaliação da Educação Superior - Gepaes, pelas dicas, trocas e aprendizagens coletivas, com especial agradecimento à Claudia Griboski e à Patrícia Ruas que foram imprescindíveis no processo de coleta de dados na base do Inep.

Às amigas do doutorado, pelas conversas e apoio: Kátia Rosa, Paola Mattos, Márcia Amâncio, Arlete Botelho, Maria Marta Couto, Ana Paula Matos, Kelli Queiroz e Ana Lúcia Duarte. Valeu!

À Controladoria Geral da União pelo sistema de acesso à informação que foi muito valioso no processo de coleta de dados, bem como pela atenção e comprometimento dos auditores quando precisei.

Aos coordenadores dos cursos presenciais de pedagogia do Plano Nacional de Formação de Professores da Educação Básica (Parfor) que me atenderam com cortesia e atenção, viabilizando a realização da etapa de entrevistas.

Ao meu marido e companheiro, Francisco Djalma de Oliveira, pela paciência e ajuda nos momentos em que mais precisei de apoio.

Por fim, mas não por último, aos meus pais, Antônio e Valdice, meus familiares e amigos queridos que sempre estiveram ao meu lado, tornando os desafios mais amenos. A todos vocês, cujos nomes estão gravados no meu coração, os meus sinceros agradecimentos. 


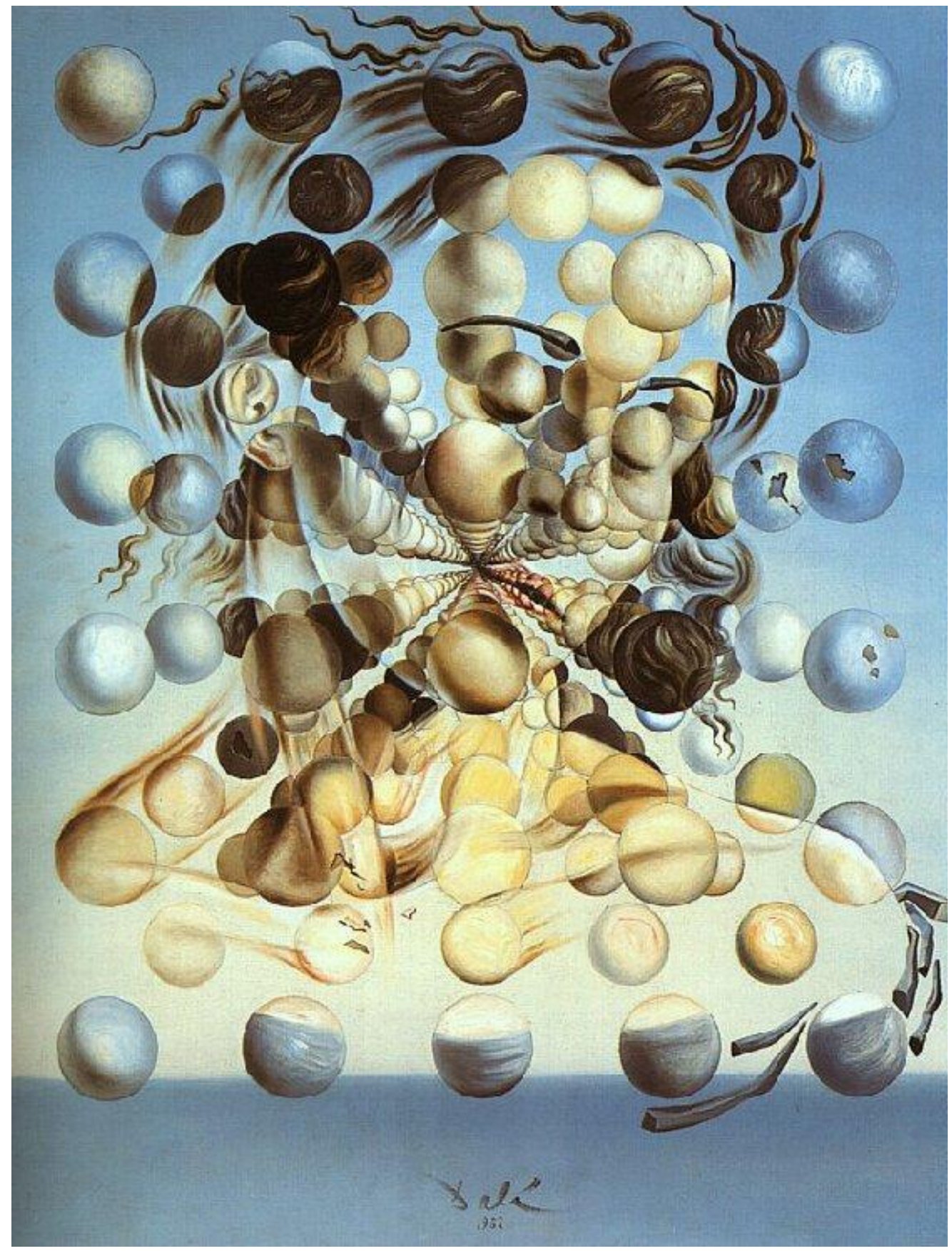

GALATEA DE LAS ESFERAS (1952)

SALVADOR DALÎ́ 



\section{RESUMO}

Esta pesquisa investigou a relação estabelecida entre os critérios de qualidade existentes na oferta das licenciaturas presenciais em pedagogia do Parfor (Plano Nacional de Formação de Professores da Educação Básica) e aqueles utilizados pelo Sinaes (Sistema Nacional de Avaliação da Educação Superior) para avaliar os cursos de pedagogia em geral. Sob a fundamentação epistemológica do hiperempirismo dialético (GURVITCH, 1987), a análise dessa relação permitiu identificar a Política de Qualidade para a Formação Inicial de Professores da Educação Infantil e dos Anos Iniciais do Ensino Fundamental (Política de Qualidade). A construção teórica do estudo assumiu que tal política emergiu da relação investigada, difundindo o padrão estabelecido (de fato) pelo governo brasileiro para orientar a qualidade dos cursos em foco. Três diretrizes sustentaram as discussões teórico-empíricas da pesquisa: (i) análise das ações e das não ações do governo brasileiro nas áreas de formação de professores e de qualidade da educação superior, bem como os embates em torno delas que relacionaram os critérios de qualidade do Sinaes e do Parfor como uma política pública específica; (ii) análise do conceito e do significado de qualidade tanto na educação superior quanto na formação inicial de professores, com destaque para as licenciaturas em pedagogia; e, (iii) análise dos critérios de qualidade identificados na oferta pelo Parfor e nas avaliações realizadas pelo Sinaes dos referidos cursos. Os dados, analisados por meio da hermenêutica, tiveram como fontes: a) entrevistas com coordenadores de cursos presenciais de pedagogia, primeira licenciatura, do Parfor; b) atas das reuniões do Conselho Técnico-Científico da Educação Básica da Coordenação de Aperfeiçoamento de Pessoal de Nível Superior (Capes) nas quais se discutiram as bases do desenvolvimento do Parfor; e c) relatórios divulgados pelo Sinaes sobre indicadores de qualidade das licenciaturas em pedagogia (2008 e 2011), acrescida de uma amostra de relatórios das avaliações in loco realizadas nesse tipo de curso, referentes ao ciclo avaliativo de 2008. Os resultados apontaram que: 1) o Sinaes possui pseudocritérios que não são capazes de revelar os perfis de qualidade dos cursos de pedagogia em relação aos cinco níveis previstos na sua escala de medida, tampouco o significado dos resultados aferidos por seus instrumentos para avaliar esses cursos (CPC e avaliações in loco); 2) há limites operacionais para que o Sinaes alcance os arranjos estabelecidos no âmbito do Parfor para a oferta dos cursos em questão e existe baixo uso dos resultados aferidos pelo sistema avaliativo; e 3) os critérios de qualidade emergidos da realidade do Parfor não foram capazes de parametrizar características básicas, compartilhadas por seus cursos de pedagogia. Os resultados confirmaram, ainda, a hipótese de desconexão ou, mais propriamente, ambiguidade na relação estabelecida entre os critérios de qualidade utilizados pelo Parfor e pelo Sinaes, respectivamente, na oferta e na avaliação de cursos de pedagogia, corroborando a tese de que o padrão de qualidade emanado pelo governo brasileiro para orientar a formação nessa área é impreciso.

Palavras-Chave: 1. Políticas Públicas. 2. Qualidade. 3. Parfor. 4. Sinaes. 5. DCN da licenciatura em pedagogia. 



\begin{abstract}
This research investigates the connection between the quality criteria established by PARFOR (Plano Nacional de Formação de Professores da Educação Básica) to offer face-to-face Pedagogy graduation courses and the ones used by SINAES (Sistema Nacional de Avaliação da Educação Superior) to evaluate the existing Pedagogy courses in Brazil. Based on the epistemological concepts of dialectical hyper-empiricism (GURVITCH, 1987), this relation was associated with Quality Policy for the Initial Training of Preschool and Early Years Primary School Teachers (Quality Policy). The theoretical basis of the study considered that the aforementioned policy was a result of the investigated connection, propagating the criteria established (indeed) by the Brazilian government to guide the quality of the Pedagogy courses. The theoretical-empirical discussions were based in three guidelines: (i) the analysis of the Brazilian government actions and non-actions towards teacher training and the quality of University education, as well as the discussions on the matter that resulted in the adoption of the quality criteria of SINAES and PARFOR as a specific public policy; (ii) analysis of the concept and meaning of quality concerning University education as well as initial teacher training, focusing on Pedagogy graduation courses; and, (iii) analysis of the quality criteria identified in the courses offered by PARFOR and the SINAES evaluations of the same courses. The information used was obtained from the following sources: a) interviews with coordinators of Pedagogy graduation courses, as a first graduation, from PARFOR; b) minutes of meetings of the Council of Scientific-Technical Education Basic of CAPES (Coordenação de Aperfeiçoamento de Pessoal de Nivel Superior) in which they discussed the basis for development of PARFOR; c) reports released by SINAES on quality indicators of the Pedagogy graduation courses (2008 and 2011) plus evaluations reports performed where the courses took place, for the 2008 evaluation cycle. These data were then analyzed through a hermeneutic method. The results showed that: 1) SINAES has false evaluation criteria that are not able to reveal the quality of the Pedagogy courses according to the five levels concerned by the measurement scale, nor reveal the meaning of the results obtained by the evaluation instruments (CPC and on-site evaluations); 2) there are operational limits for the SINAES to reach the arrangements established by the PARFOR for offering Pedagogy courses and there is low use of the results obtained by the evaluation system; and 3) the quality criteria that emerged from PARFOR were not able to parameterize basic characteristics shared by Pedagogy courses. The results confirmed also the possibility of disconnection or, more precisely, ambiguity in the relationship established between the quality criteria used by PARFOR and the ones used by SINAES, respectively, in the provision and in the evaluation of Pedagogy courses, supporting the thesis that the quality standard established by the Brazilian government to guide the Pedagogy formation is inaccurate.
\end{abstract}

Keywords: 1. Public Policy. 2. Quality. 3. PARFOR. 4. SINAES. 5. National Curriculum Guidelines for Pedagogy courses. 



\section{LISTA DE FIGURAS}

Figura 1 - Representação gráfica do conceito de qualidade na educação

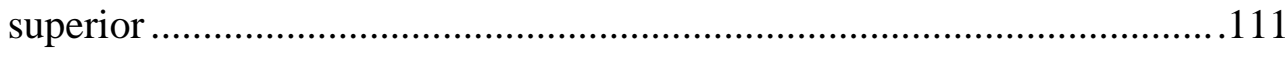

Figura 2 - Indicador 1.6: conteúdos curriculares.................................................... 116

Figura $3-\quad$ Transcrição dos arts. $7 .^{\circ}$ e $8 .^{\circ}$ das DCN da licenciatura em pedagogia ....... 185 



\section{LISTA DE GRÁFICOS}

Gráfico 1 - Oferta de turmas dos cursos do Parfor - janeiro/2012 (Brasil) .49

Gráfico 2 - Número de alunos matriculados no Parfor - janeiro/2012 (Brasil) .50

Gráfico 3 - Número de cursos presenciais de pedagogia por categoria administrativa e organização acadêmica - 1995 a 2013 (Brasil)

Gráfico 4 - Percentual de matrículas por UF no Parfor Presencial - janeiro/2012 2.......77

Gráfico 5 - Distribuição dos professores da educação básica sem formação superior por UF - 2009

Gráfico 6 - Percentual de docentes da educação básica sem formação superior no Brasil e por UF - 2009

Gráfico 7 - Estrutura da amostra de coordenadores do curso de pedagogia do Parfor Presencial, categoria administrativa e região - julho/2013 



\section{LISTA DE TABELAS}

Tabela 1 - Diretrizes de análise, categorias analíticas e fontes de informação para coleta de dados

Tabela 2 - Número de matrículas do Parfor Presencial em cursos de primeira licenciatura - janeiro/2012 (Brasil)

Tabela 3 - Distribuição dos professores da educação básica por nível de formação e níveis de ensino em que atuam - 2009 (Brasil)....

Tabela 4 - Universo e amostra de relatórios de avaliações in loco, por situação do curso.

Tabela 5 - Distribuição de frequência de enunciados referentes à dimensão organização didático-pedagógica, presentes nos relatórios de avaliação in loco.

Tabela 6 - Número de coordenadores de cursos de pedagogia, primeira licenciatura, do Parfor Presencial ativos no Sistema Geral de Bolsas (SGB) da Capes - julho/2013

Tabela 7 - Distribuição dos cursos da amostra de relatórios de avaliação in loco, em função da nota aferida em 2008 e da nota no CPC 2011

Tabela 8 - Distribuição dos alunos do Parfor Presencial matriculados em cursos de pedagogia primeira licenciatura, por CPC 2011 e categoria administrativa da IES - janeiro/2012 (Brasil) 



\section{LISTA DE ABREVIATURAS E SIGLAS}

ABNT Associação Brasileira de Normas Técnicas

Abruc Associação Brasileira de Universidades Comunitárias

ABT Associação Brasileira de Tecnologia Educacional

ACC Atividades [Curriculares] Complementares

AITSL Australian Institute for Teaching and School Leadership

AMN Associação Mercosul de Normalização

Anfope Associação Nacional pela Formação dos Profissionais da Educação

Anped Associação Nacional de Pós-Graduação e Pesquisa em Educação

Bird Banco Internacional para Reconstrução e Desenvolvimento

Capes Coordenação de Aperfeiçoamento de Pessoal de Nível Superior

Cedes Centro de Desenvolvimento e Educação Superior

CEESP Conselho Estadual de Educação de São Paulo

CGDOC Coordenação-Geral de Apoio à Formação e Capacitação Docente da Educação Básica

Clacso Conselho Latinoamericano de Ciências Sociais

$\mathrm{CNE}$ Conselho Nacional de Educação

Comung Consórcio das Universidades Comunitárias Gaúchas

Conaes Comissão Nacional de Avaliação da Educação Superior

COPANT Comissão Panamericana de Normas Técnicas

CPA Comissão Própria de Avaliação

CPC Conceito Preliminar de Cursos

CPF Cadastro de Pessoa Física

CS Conselho Superior

CTC-EB Conselho Técnico-Científico da Educação Básica

CTC-ES Conselho Técnico-Científico da Educação Superior

Daes Diretoria de Avaliação da Educação Superior

DCN Diretrizes Curriculares Nacionais

DEB Diretoria de Formação de Professores da Educação Básica

E-MEC Sistema eletrônico de fluxo de trabalho e gerenciamento de informações

Enade Exame Nacional de Desempenho dos Estudantes

ENC Exame Nacional de Cursos 
Enem Exame Nacional do Ensino Médio

Estrado Rede Latinoamericana de Estudos sobre o Trabalho Docente

Forgrad Fórum Nacional dos Pró-Reitores de Graduação

Fundeb Fundo de Desenvolvimento da Educação Básica

Gepaes Grupo de Estudos sobre Políticas de Avaliação da Educação Superior

Gestar Programa Gestão da Aprendizagem Escolar

IC Iniciação Científica

Ideb Índice de Desenvolvimento da Educação Básica

IEC International Eletrotechnical Comission

IES Instituição de Educação Superior

IGC Índice Geral de Cursos Avaliados da Instituição

Inep Instituto Nacional de Estudos e Pesquisas Educacionais Anísio Teixeira

Inmetro Instituto Nacional de Metrologia, Qualidade e Tecnologia

ISO International Organization for Standardization

Kipus Rede Docente da América Latina e do Caribe

LDB Lei de Diretrizes e Bases da Educação Nacional

MEC Ministério da Educação

NIDD Nota do Indicador de Diferença entre os Desempenhos Observado e

Esperado

OCDE Organização para a Cooperação e Desenvolvimento Econômico

OEA Organização dos Estados Americanos

PAR Planos de Ações Articuladas

Parfor Plano Nacional de Formação de Professores da Educação Básica

Pibid Programa Institucional de Bolsas de Iniciação à Docência

PIP Programa de Intervenção Pedagógica

PPC Projeto Pedagógico do Curso

Proex Programa de Excelência Acadêmica

Profmat Programa de Mestrado Profissional em Matemática em Rede Nacional

Pronatec Programa Nacional de Acesso ao Ensino Técnico e Emprego

RIED Rede Interamericana de Educação Docente

Saeb Sistema de Avaliação da Educação Básica

SBM Sociedade Brasileira de Matemática

SC Sem conceito 
SEB

Secretaria de Educação Básica

Seres

Secretaria de Regulação da Educação Superior

SGB

Sistema Geral de Bolsas

Sinaes

Sistema Nacional de Avaliação da Educação Superior

SNPG

Sistema Nacional de Pós-Graduação

TCC

Trabalho de Conclusão de Curso

TEQSA

Tertiary Education Quality and Standards Agency

TIC

tecnologias de informação e comunicação

TRI

Teoria de Resposta ao Item

$\mathrm{UAB}$

Sistema Universidade Aberta do Brasil

UF

Unidade da Federação

UnB

Universidade de Brasília

Unesco

Organização das Nações Unidas para a Educação, a Ciência e a Cultura 



\section{SUMÁRIO}

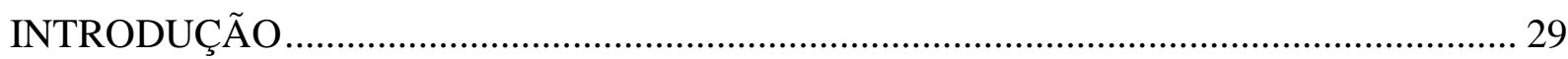

1 POLÍTICA DE QUALIDADE PARA A FORMAÇÃO INICIAL DE

PROFESSORES DA EDUCAÇÃO INFANTIL E DOS ANOS INICIAIS DO

ENSINO FUNDAMENTAL.

1.1 CONTEXTO HISTÓRICO DE EMERGÊNCIA DA POLÍTICA QUALIDADE ...... 47

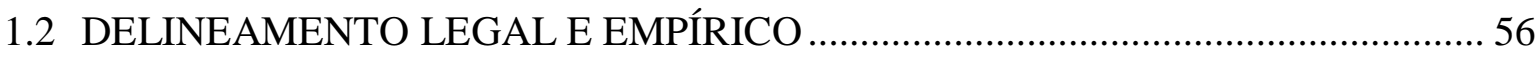

1.3 CONSTRUÇÃO TEÓRICA PARA UMA REALIDADE DE FATO ......................... 60

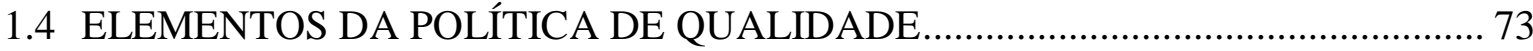

1.4.1 Plano Nacional de Formação de Professores da Educação básica: formatação e desenvolvimento ..................................................................... 73

1.4.2 DCN da licenciatura em pedagogia: embates conceituais ................................ 81

1.4.3 Sistema Nacional de Avaliação da Educação Superior: configuração e objetivos

2 QUALIDADE: DO CONCEITO AMORFO À DEFINIÇÃO DE CRITÉRIOS

PARA OFERTA E AVALIAÇÃO DA LICENCIATURA EM PEDAGOGIA................... 93

2.1 APROXIMAÇÕES AO CONCEITO DE QUALIDADE ...................................... 93

2.1.1 Critérios como aspecto central na definição de qualidade ............................... 101

2.2 BASES PARA IDENTIFICAÇÃO OPERACIONAL DE QUALIDADE NA FORMAÇÃO DE PEDAGOGOS

2.2.1 Concepções de formação de professores ..................................................... 120

2.2.2 Aspectos de qualidade destacados pela legislação brasileira ............................ 129

2.2.3 Experiências internacionais sobre qualidade na formação docente................... 137

3 CONCEPÇÃO DE QUALIDADE NA FORMAÇÃO DE PEDAGOGOS NO BRASIL

3.1 CAMINHOS PERCORRIDOS PARA A IDENTIFICAÇÃO DA QUALIDADE NA FORMAÇÃO DO PEDAGOGO.

3.2 CRITÉRIOS DE QUALIDADE USADOS PELO SINAES PARA AVALIAR AS LICENCIATURAS PRESENCIAIS EM PEDAGOGIA................................... 151

3.2.1 Indicadores e parâmetros das avaliações in loco ............................................. 151

3.2.1.1 Concepções de formação docente ...................................................... 154

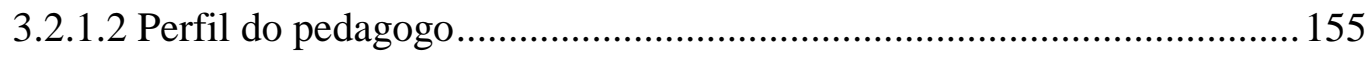


3.2.1.4 Outros aspectos: gestão, legalidade, repertório de conhecimentos dos estudantes, parcerias e autoavaliação.

3.2.2 Conceito Preliminar de Cursos e sua relação com a avaliação in loco ..... 164

3.2.2.1 O Enade como indicador de qualidade 170

3.3 O QUE REVELAM AS AVALIAÇÕES DE CURSOS DO SINAES SOBRE A QUALIDADE DA FORMAÇÃO DE PEDAGOGOS NO BRASIL?

3.4 CRITÉRIOS DE QUALIDADE PRESENTES NA OFERTA DA LICENCIATURA PRESENCIAL EM PEDAGOGIA DO PARFOR

4 QUALIDADE NA FORMAÇÃO DE PROFESSORES: DA PROPOSTA DE UM SISTEMA À REALIDADE DE UMA POLÍTICA.

4.1 EMBATES, (NÃO) AÇÕES E OMISSÕES QUE CONFIGURARAM A POLÍTICA DE QUALIDADE.

4.2 PADRÃO DE QUALIDADE SINALIZADO PELO GOVERNO BRASILEIRO

PARA A LICENCIATURA EM PEDAGOGIA …...................................................... 221

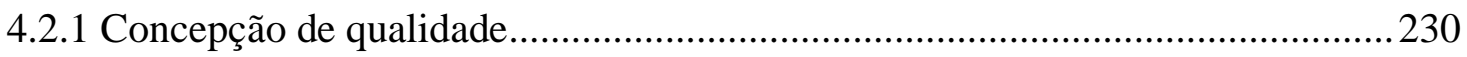

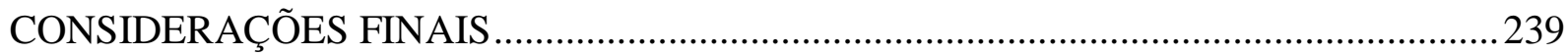

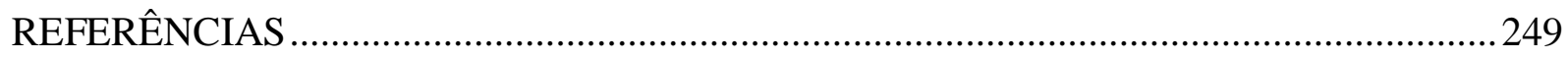

APÊNDICE A - Justificativa da escolha do método de pesquisa ....................................... 265

APÊNDICE B - Carta de apresentação aos Coordenadores(as) do Curso de pedagogia do Parfor Presencial (amostra definitiva de pesquisa) ...................................2273

APÊNDICE C - Termo de consentimento livre e esclarecido (Coordenador) .......................2275

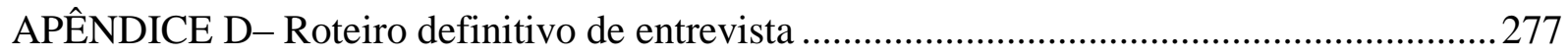

APÊNDICE E - Solicitação de dados ao Inep................................................................2. 279

APÊNDICE F - Pré-teste do roteiro piloto de entrevista ..................................................... 281

APÊNDICE G - Coleta piloto de dados: Carta de apresentação aos coordenadores

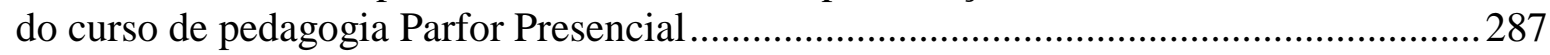

APÊNDICE H - Instrumentos piloto de coleta de dados .................................................289

APÊNCICE I - Plano de Trabalho (Doutorado Sanduíche) .................................................. 291

APÊNDICE J - Relatório de Atividades (Doutorado Sanduíche) ........................................ 295 


\section{INTRODUÇÃO}

Esta pesquisa de doutorado foi realizada no Programa de Pós-Graduação em Educação da Universidade de Brasília (UnB), no âmbito da linha de pesquisa Políticas Públicas e Gestão da Educação. Por meio dela, investigou-se a relação estabelecida entre os critérios de qualidade presentes na oferta de licenciaturas em pedagogia do Plano Nacional de Formação de Professores da Educação Básica (Parfor) e aqueles utilizados pelo Sistema Nacional de Avaliação da Educação Superior (Sinaes) para avaliar esses cursos em geral.

No contexto desta pesquisa, a análise dessa relação possibilitou a identificação do padrão de qualidade emanado das ações do governo brasileiro no campo da oferta e da avaliação dos cursos de pedagogia, delineando a Política de Qualidade para a Formação Inicial de Professores da Educação Infantil e dos Anos Iniciais do Ensino Fundamental. Assim, apesar da ausência de documento legal e de previsão orçamentária que definisse a referida política, assumiu-se o pressuposto de que ela existe (de fato) por meio da relação investigada. Tal pressuposto foi embasado pelos indícios empírico-legais e, principalmente, pelas ideias de Gramsci (1966, 1982), Lowi (1964, 1972), Jobert e Muller (1987); Skocpol (2002), Muller e Surel (2002), Muller (2002); Souza (2006) e Dye (2012). Com base nesses autores, foi possível considerar a existência de políticas públicas, independentemente da sua formalização, pelas ações e/ou não ações de governos, empreendidas, ou não, por instrumentos estruturados, lineares e coerentes, em prol dos interesses em disputa pelos diversos grupos e instituições afetados por elas.

No caso da política em foco, identificou-se a sua emergência a partir da publicação do Decreto n. ${ }^{\circ}$ 6.755, de 29 de janeiro de 2009 (BRASIL, 2009a), que institucionalizou a Política Nacional de Formação de Profissionais do Magistério da Educação Básica - também chamada neste trabalho de política de formação docente - e viabilizou a criação do Parfor por meio da Portaria Normativa n. ${ }^{\circ}$ 9, de 30 de junho de 2009 (BRASIL, 2009b). Em síntese, ${ }^{1}$ o Parfor voltou-se notadamente ao atendimento da demanda por diplomação em nível superior de professores das redes públicas de educação básica, com garantia de "padrão de qualidade dos cursos de formação de docentes ofertados pelas instituições formadoras nas modalidades presencial e a distância”, conforme definido no inciso IV do art. $2 .^{\circ}$ do referido decreto.

No entanto, esse padrão de qualidade não foi formalmente estabelecido pelo Parfor. Além disso, no caso dos cursos de iniciação à docência, o Sinaes - que avalia e estabelece a qualidade dos cursos de graduação brasileiros - não alterou seus objetivos para alcançar as

\footnotetext{
${ }^{1}$ A análise da implantação e do desenvolvimento do Parfor foi realizada no capítulo 1 desta tese.
} 
particularidades dessa formação dentro do plano de formação. As limitações operacionais do sistema avaliativo não o permitiram alcançar as turmas especiais do Parfor, oferecidas com base em projeto pedagógico distinto, corpo docente diverso e infraestrutura alternativa ao que existe nas demais turmas do curso. Além disso, legalmente, as avaliações do Sinaes não provocam, necessariamente, consequências regulatórias sobre cursos não pertencentes ao Sistema Federal de Ensino Superior. ${ }^{2}$ Assim, visualizou-se que o padrão de qualidade aludido como princípio pela política de formação docente poderia ser encontrado, no que tange à formação inicial, a partir da associação entre as características de qualidade assumidas na própria oferta desses cursos pelo Parfor e aquelas utilizadas pelo Sinaes na avaliação da formação superior no país.

Reforçou essa compreensão a submissão do Sinaes e do Parfor às Diretrizes Curriculares Nacionais (DCN), ${ }^{3}$ sugerindo a articulação deles em torno de um padrão de qualidade para cursos de iniciação à docência. Assumiu-se, então, que as orientações contidas nas DCN operacionalizariam critérios de qualidade apropriados pelo Sinaes, na avaliação de cursos de licenciatura, e pelo Parfor, na oferta de formação inicial para docentes da educação básica. No seu conjunto, tais critérios sintetizariam o padrão de qualidade assumido pelo governo brasileiro em prol dessa formação, refletindo-se em uma política pública de fato.

Dentro desse pressuposto, destacou-se ainda o entendimento de que apesar da centralidade das orientações emanadas das DCN para as ações do Parfor e do Sinaes, respectivamente, na oferta e avaliação de licenciaturas, a relação estabelecida entre o que essas políticas públicas assumem individualmente como critérios de qualidade para a formação adequada de docentes no Brasil precisaria ser esclarecida, tendo em vista: (i) as discussões sobre o termo qualidade ${ }^{4}$ que apontaram sua natureza polissêmica, colocando em evidência as dificuldades de um documento legal, como é o caso das DCN, precisar o que é formação docente adequada; (ii) as dificuldades dos instrumentos avaliativos do Sinaes para atender às especificidades das licenciaturas, uma vez que foram concebidos para atender isomorficamente $^{5}$ a todas as áreas de conhecimento; (iii) a inexistência de diretrizes

2 O art. 2. ${ }^{\circ}$ do Decreto $n^{\circ}$ 5.773, de 9 de maio de 2006, que dispõe sobre as funções de regulação, supervisão e avaliação de instituições e cursos superiores (BRASIL, 2006a) esclarece que o Sistema Federal de Ensino Superior compreende as instituições federais de educação superior, as instituições de educação superior criadas e mantidas pela iniciativa privada e os órgãos federais de educação superior. Desse modo, IES estaduais e municipais, embora possam oferecer cursos sob a chancela do Parfor, não são submetidas à regulação embasada no Sinaes, uma vez que não integram o sistema federal.

3 Essa submissão foi definida pela Lei de Diretrizes e Bases da Educação Nacional (LDB) (BRASIL, 1996).

4 As discussões sobre o conceito de qualidade foram aprofundadas no capítulo 2 desta tese.

5 Na acepção trazida por Morosini (2001), refere-se à padronização de dimensões que subsidiam o processo avaliativo, adequando a educação superior à competição. 
acadêmicas para a seleção e estruturação dos cursos oferecidos sob a chancela do Parfor; (iv) os embates sobre qualidade na educação superior brasileira decorrentes das discussões acadêmicas em torno dos princípios norteadores da avaliação do Sinaes se voltados à emancipação institucional ou à regulação de cursos/instituições de educação superior (IES); e (v) as diferenças regulatórias em torno dos cursos do Parfor que não integram o Sistema Federal de Ensino Superior, submetendo-se em caráter optativo ao Sinaes.

Considerando esse contexto problemático, localizou-se no padrão de qualidade resultante das ações do governo brasileiro para a oferta e a avaliação da formação inicial de professores um objeto de pesquisa relevante. Os argumentos para sustentar essa relevância foram encontrados em duas vertentes. A primeira, sob o domínio do campo da avaliação da educação superior, na medida em que o objeto de pesquisa ofereceu a possibilidade de analisar os dados disponibilizados pelo Sinaes na realidade concreta dos cursos de licenciatura, detalhando seus limites e potencialidades. Já a segunda vertente de relevância foi relacionada à formação de professores como política pública, cuja envergadura de investimentos nominais alocados pela União, diretamente ou por transferências voluntárias, segundo dados disponíveis no Portal da Transparência do Governo Federal, atingiu, em valores nominais, cerca de $\mathrm{R} \$ 1$ 100.000.000,00 (um bilhão e cem milhões de reais) entre os anos de 2009 e 2011 (PORTAL..., 2012). A título de comparação, o montante desses recursos no período imediatamente anterior à publicação da política de formação docente (BRASIL, 2009a) - 2006 a 2008 - foi de apenas R \$ 166.000.000,00 (cento e sessenta e seis milhões de reais), segundo a mesma fonte. Assim, teve-se como horizonte a possibilidade de que os resultados da presente pesquisa auxiliassem o aperfeiçoamento do Sinaes, bem como do fomento à formação inicial de docentes da educação básica.

Adicionalmente, constatou-se que a maioria dos alunos do Parfor estava matriculada em cursos destinados à formação em primeira licenciatura, notadamente na modalidade presencial. Conforme dados relativos ao ano de $2012^{6}$, do total de matrículas, $77 \%$ foram realizadas nos cursos presenciais de primeira licenciatura, distribuídas em pelo menos 20 áreas de formação.

Observou-se ainda que, entre as áreas de oferta dos cursos presenciais de primeira licenciatura, houve grande concentração dos alunos na área de pedagogia (cerca de $40 \%$ desse total). A título de comparação, a segunda área com maior percentual de alunos matriculados

\footnotetext{
${ }^{6}$ Esses dados foram disponibilizados pela Capes para esta pesquisa e estão sistematizados no Gráfico 2, seção 1.1 .
} 
em cursos presenciais de primeira licenciatura foi Letras, com apenas 10,7\% desse total de matriculados. $^{7}$

A partir das características das matrículas no Parfor, associadas ao contexto problematizado e aos argumentos em torno da relevância de se estudar o padrão de qualidade difundido pelo governo brasileiro por meio de suas ações de oferta e a avaliação da formação inicial de professores, emergiu a seguinte pergunta de pesquisa: qual a relação estabelecida entre os critérios de qualidade utilizados pelo Sinaes para subsidiar a regulação da licenciatura em pedagogia e aqueles existentes na oferta presencial dessas licenciaturas pelo Parfor?

Tal pergunta considerou o Parfor e o Sinaes como elementos integrantes das ações do governo brasileiro voltadas à adequada formação inicial de professores da educação infantil e dos anos iniciais do ensino fundamental no país. Além disso, de forma subjacente, a pergunta destacou, ainda, as DCN da licenciatura em pedagogia como mais um elemento dessas ações, balizando as relações entre os critérios de qualidade do Parfor e do Sinaes para a área em foco como uma política pública específica. Essa política foi aqui denominada de Política de Qualidade para a Formação Inicial de Professores da Educação Infantil e dos Anos Iniciais do Ensino Fundamental (Política de Qualidade), ${ }^{8}$ sendo considerada como responsável por estabelecer implicitamente o padrão orientador da qualidade dos cursos de licenciatura em pedagogia no País.

Além disso, a pergunta de pesquisa considerou a densidade de matrículas nos cursos presenciais do Parfor, tendo-se optado exclusivamente pela análise dessa modalidade, em detrimento de uma combinação com cursos oferecidos a distância. Contribuíram para essa opção: (i) as diferenças metodológicas e de requisitos legais entre as modalidades de oferta; (ii) a condução política do Ministério da Educação (MEC) que, desde a extinção da Secretaria de Educação a Distância em 2011, tem sido marcada pela perspectiva de reciprocidade entre a educação presencial e a educação a distância nas ações do Ministério, bem como pela utilização de um único instrumento de avaliação pelo Sinaes; e (iii) as orientações das DCN de cursos que não fazem distinção entre as modalidades. Nesse sentido, ao estabelecer o foco na modalidade presencial da oferta dos cursos do Parfor, entendeu-se que ao mesmo tempo que se obtinha simplificação do quadro de análise, a escolha não traria prejuízos à

${ }^{7}$ Esses dados foram fornecidos em janeiro de 2012 pela Coordenação de Aperfeiçoamento de Pessoal de Nível Superior (Capes) para essa pesquisa e estão detalhados no Gráfico 2 e na Tabela 2, disponíveis no capítulo 1 desta tese.

${ }^{8}$ Para maior conforto do leitor, na maior parte do texto, utilizou-se o termo Política de Qualidade como referência à Política de Qualidade para a Formação Inicial de Professores da Educação Infantil e dos Anos Iniciais do Ensino Fundamental. 
investigação ora proposta, ante a perspectiva de interação entre cursos presenciais e a distância.

No que diz respeito à definição da área de pedagogia como recorte para a investigação, embora tenha sido levada em conta a sua grande representatividade no Parfor, destacou-se notadamente a sua realidade problemática. As DCN da licenciatura em pedagogia foram aprovadas pela Resolução CNE/CP n. ${ }^{\circ}$ 1, de 15 de maio de 2006 (BRASIL, 2006b), em meio a discussões entre os educadores organizados por meio da Associação Nacional pela Formação de Profissionais da Educação (Anfope) na defesa da ideia da base docente ${ }^{9}$, em contraposição a outros educadores - com destaque para Franco, Libâneo e Pimenta (2007) que criticaram essa perspectiva por trazer embutida certa generalidade formativa para o pedagogo como profissional e limitação para a pedagogia como campo teórico-investigativo. Tais discussões evidenciaram um contexto instigante de investigação, reforçando o recorte que delimitou o estudo do padrão de qualidade para a formação inicial de professores, em torno daqueles docentes formados para atuar na educação infantil e anos iniciais do ensino fundamental (o pedagogo).

À medida que o estudo ia se definindo, emergiam também justificativas de ordem acadêmica, profissional e pessoal para o seu desenvolvimento. Do ponto de vista acadêmico, constatou-se carência de análises sobre o Parfor, notadamente em relação aos critérios de qualidade utilizados para a oferta de cursos de formação inicial. A recente implantação do Parfor fez dele um campo de investigação a ser desbravado, como demonstrou a busca realizada no Banco de Teses da Capes em 13/12/2012, que retornou com resultado "zero" para pesquisa de mestrado ou doutorado com registro do termo "Parfor". Já a busca realizada em 13/11/2014 retornou como resultado três dissertações de mestrado acadêmico. Contudo, em nenhuma delas a questão da qualidade na oferta dos cursos foi tratada.

Já no Google Scholar - que oferece um mecanismo de busca especializada em bases indexadas e demais sítios de conteúdo científico - também em 13/12/2012, a procura por documentos que continham o termo "Parfor" retornou como resultado 246 referências, todas elas sem aderência à perspectiva de qualidade dos cursos de formação. Quase dois anos depois (13/11/2014), essa mesma busca foi realizada. Dessa vez, foram retornados 1.110 documentos, dos quais, em pelo menos um, houve referências à aplicabilidade das avaliações do Sinaes no âmbito do Parfor. Porém, esse documento, por sua natureza (trabalho para

\footnotetext{
${ }^{9}$ Conceito explorado na seção 1.4.2, que resume a tese de que o pedagogo é um "profissional habilitado a atuar no ensino, na organização e na gestão de sistemas, unidades e projetos educacionais e na produção e difusão do conhecimento, em diversas áreas da educação, tendo a docência como base obrigatória de sua formação e identidade profissional" (SCHEIBE; AGUIAR, 1999, p. 232).
} 
cumprimento de créditos em disciplinas de curso de pós-graduação), apresentou uma análise superficial sobre seu objeto de análise, sem trazer referências sobre as relações entre Parfor e Sinaes em torno de critérios de qualidade para a formação de professores. Com isso, entendeu-se que a realização da presente pesquisa poderia contribuir para a geração de conhecimentos em torno da formação de docentes da educação básica com qualidade.

Além disso, emergiu como justificativa acadêmica para a realização do estudo o próprio processo de aprovação das $\mathrm{DCN}$ da licenciatura em pedagogia. Esse processo destacou a concepção da docência como elemento central na formação do pedagogo, visando superar a dicotomia entre a licenciatura e o bacharelado, então identificada. Em linhas gerais, a proposta da base docente ampliou o significado da docência na área de pedagogia, assumindo que esta, além do ato de ministrar aulas, compreenderia a participação do egresso do curso nas atividades de organização e gestão de sistemas e instituições de ensino. ${ }^{10}$

Nas discussões que se seguiram à aprovação da proposta da base docente, Libâneo (2006), por exemplo, questionou as condições de um único curso ser capaz de formar com qualidade e, ao mesmo tempo, um profissional para atuar: i) no magistério da educação infantil e dos anos iniciais do ensino fundamental; ii) nas atividades de planejamento, execução, coordenação, acompanhamento e avaliação de tarefas próprias do setor da educação e de experiências educativas não escolares; e iii) na produção e difusão do conhecimento científico-tecnológico do campo educacional, em contextos escolares e não escolares. O foco das discussões pareceu centrar-se no perfil de formação do aluno egresso do curso de pedagogia e sua possibilidade de contribuir, prioritariamente, para a qualidade da escola básica.

Alimentando essa discussão, os relatos de Gatti (2009, 2010) sobre a estrutura curricular dos cursos de licenciatura em pedagogia concluíram que estes enfatizavam pouco os conteúdos diretamente afetos à docência - associados às disciplinas a serem ministradas na educação básica, bem como as suas didáticas. Assim, tais resultados, aliados às contestações que permearam a aprovação das DCN da licenciatura em pedagogia, suscitaram ainda mais dúvidas sobre como a qualidade destacada pelo documento legal se materializou no contexto dos cursos do Parfor e das avaliações exaradas pelo Sinaes.

\footnotetext{
${ }^{10}$ Como definem Aguiar e Melo (2005, p. 126-127), a docência passou a ser entendida como "fulcro de articulação dos diversos conhecimentos - aportes teóricos da pedagogia e das ciências da educação e de outros conhecimentos especializados e daqueles produtos das práticas escolares e não escolares refletidas [...] Nesse sentido, a docência constitui uma das mediações para a construção do discurso de síntese da pedagogia, articulada intrinsecamente com a pesquisa”.
} 
No caso específico das avaliações do Sinaes, os resultados apresentados pelo estudo exploratório realizado no âmbito desta investigação e publicado na $36^{\mathrm{a}}$ Reunião Nacional da Associação Nacional de Pós-Graduação e Pesquisa em Educação (Anped) apontaram para dificuldades do sistema avaliativo na apropriação da orientação legal em torno da base docente (SOUZA, 2013). Esse estudo constatou que o Exame Nacional de Desempenho dos Estudantes (Enade) da licenciatura em pedagogia, referente aos anos de 2005, 2008 e 2011, focalizou conhecimentos classificados pelo próprio Enade como gerais, quando era esperado, em função da ideia de docência ampliada, um equilíbrio entre esses e aqueles conhecimentos classificados como específicos das áreas de docência e de gestão educacional. Nesse sentido, reforçaram-se os argumentos que justificaram a realização desta pesquisa, dentro da perspectiva de maior explicitação do significado da qualidade da licenciatura em pedagogia na prática do Parfor e do Sinaes.

Já na vertente de argumentos de ordem profissional, a investigação em tela se justificou pela experiência de trabalho de sua autora na Capes, principal órgão responsável tanto pela elaboração e execução da política de formação docente no Governo Federal quanto pela condução do mais consolidado processo de avaliação da educação superior em âmbito nacional, iniciado na década de 1970. Desde a sua criação em 1951, a Capes teve por missão incentivar a qualificação de docentes para a educação superior, assim como os demais profissionais de alto nível para atender à pesquisa, ao desenvolvimento e à inovação no País. Nesse processo, desenvolveu seu modelo de avaliação, aplicado no âmbito da pós-graduação para garantir a qualidade dos cursos responsáveis pela formação em foco. A partir de 2007, foi agregado à sua missão o desafio de também estimular a formação de docentes para a educação básica, com a diferença de que a avaliação da qualidade desses cursos não estaria sob a sua esfera de responsabilidade, mas sob a égide do Sinaes, gerenciado pelo Instituto Nacional de Estudos e Pesquisas Educacionais Anísio Teixeira (Inep). As convergências e distinções no desenvolvimento das velhas e novas ações para a formação docente na Capes ainda não foram consolidadas, justificando a realização de pesquisas que auxiliem seu entendimento para a superação de desafios. Assim, configurou-se também como um dos motivos para a realização deste estudo a explicitação da qualidade assumida pelo Parfor e pelo Sinaes, visando construir saberes que fortaleçam essas duas políticas públicas.

Em termos da justificativa de ordem pessoal para realizar essa investigação, destacouse o desafio de entender os principais conflitos históricos, teóricos e políticos do campo das políticas públicas de formação de professores, notadamente na área de pedagogia, reconhecendo-se sua importância estratégica para a educação básica brasileira. Além disso, a 
história profissional e acadêmica desta pesquisadora em torno do tema avaliação gerou interesse pelo tema em estudo, catalisada pela oportunidade desta pesquisa permitir a análise do sistema nacional de avaliação de forma contextualizada, tendo como referência os cursos de pedagogia sob a chancela do Parfor.

Assim, considerando-se como válidas a pergunta de pesquisa e as justificativas para respondê-la, iniciou-se a investigação por meio de uma reflexão dialética sobre o seu objeto. De forma explícita, tal objeto expressou-se na relação estabelecida entre os critérios de qualidade utilizados pelo Parfor e pelo Sinaes nas suas ações em torno do curso de pedagogia. De forma latente, contemplou a Política de Qualidade, na medida em que da relação investigada emanou o padrão de qualidade definido (de fato) pelo governo brasileiro em prol da adequada formação inicial de professores da educação infantil e dos anos iniciais do ensino fundamental. Esse objeto, apesar de refletir uma realidade empírica, não se originou exclusivamente dela. Emergiu do olhar sobre as ações e decisões do governo brasileiro por meio da lupa oferecida pelos quadros de referência teórica das áreas de políticas públicas, de qualidade e avaliação da educação superior, bem como de formação de professores.

Nesse sentido, considerou-se que foram as discussões teóricas em interação direta com a realidade empírica que permitiram problematizar as ações e repercussões do Parfor e do Sinaes, bem como as DCN da licenciatura em pedagogia na realidade concreta. Além disso, permitiram levantar como hipótese de investigação a existência de desconexão entre os critérios de qualidade assumidos por Parfor e Sinaes na oferta e avaliação de cursos de pedagogia em torno de temas como docência ampliada, organização curricular e até mesmo concepção de formação docente.

Dessa forma, os quadros de referência teórica puderam ser assumidos como verdadeiras fronteiras que, ao lançar luz sobre o problema investigado, terminaram por individualizá-lo como objeto de investigação. No caso desta pesquisa, tais fronteiras foram definidas a partir das seguintes diretrizes de análise:

(i) ações, não ações e omissões do governo brasileiro nas áreas de formação de professores e de qualidade da educação superior, bem como os embates em torno delas que relacionaram os critérios de qualidade do Sinaes e do Parfor, mediados pelas DCN da licenciatura em pedagogia, como uma política pública específica;

(ii) conceito e significado de qualidade na educação superior, em geral, e na formação inicial de professores, em particular, com destaque para os cursos presenciais de licenciatura em pedagogia; 
(iii) critérios de qualidade identificados na oferta pelo Parfor e nas avaliações realizadas pelo Sinaes dos cursos em foco.

Nesse sentido, tais diretrizes de análise viabilizaram a definição do objeto pesquisado, delimitando-o como proposta investigativa e indicando os caminhos pelos quais ele seria estudado. Além disso, esses balizadores teóricos terminaram por estabelecer uma ligação entre o objeto da investigação e o método hiperempirista dialético ou realista dialético, escolhido para orientar epistemologicamente a pesquisa.

Esse método, proposto por Gurvitch (1987), e cuja justificativa de escolha está presente no Apêndice A deste trabalho, foi integrado organicamente ao estudo uma vez que as diretrizes individualizaram o objeto como uma totalidade em si, destacada daquilo que estava no seu entorno. Dessa forma, imprimiu-se uma visão sistêmica à pesquisa, evidenciando o objeto de análise como uma totalidade que se insere, ela própria, em uma totalidade mais ampla. $^{11}$ Em síntese, o objeto de pesquisa - ao trazer consigo os limites impostos pelas construções teóricas materializadas pelas diretrizes de análise - terminou por delimitar a realidade empírica investigada por meio da totalidade sistêmica que caracteriza, conforme destacou Cánovas (1997), o hiperempirismo dialético.

Porém, não foi a simples individualização ou delimitação do objeto nessa totalidade que permitiu assumir as diretrizes de análise como ponte de aproximação da pesquisa às diretrizes epistemológicas do método escolhido. Conforme pontuou Gurvitch (1987), a dialética autêntica conta com o elemento especulativo, sendo um caminho para experiências sempre renovadas e que não se deixam "enclausurar em nenhum quadro operatório imóvel" (GURVITCH, 1987, p.18). Assim, no processo de delimitação do objeto por meio das diretrizes de análise, exercitou-se o hiperempirismo dialético, buscando "correr riscos [para] demolir conceitos mumificados" 12 (GURVITCH, 1987, p. 21) em torno da construção dos conceitos utilizados nesse trabalho.

Assim, analisaram-se os movimentos da relação entre os critérios de qualidade do Parfor e do Sinaes para cursos de pedagogia nas suas dimensões teórica e empírica, atentandose para as cinco possibilidades de procedimentos operatórios presentes no hiperempirismo

\footnotetext{
${ }^{11}$ A Política de Qualidade para a Formação Inicial de Professores da Educação Infantil e dos Anos Iniciais do Ensino fundamental é uma totalidade inserida em sistema mais amplo de formação de professores e da própria qualidade da educação básica, por exemplo.

12 No contexto da obra de Gurvitch (1987), conceitos mumificados puderam ser entendidos como referências à repetição de uma dada assertiva teórica, tomada inercialmente como válida, ainda que o dinamismo da vida social já a tenha ressignificado.
} 
dialético, ${ }^{13}$ a saber: i) implicação dialética múltipla, evidenciando-se interseções ou pontos de afinidade entre aspectos teóricos inerentes ao estudo da relação entre os critérios de qualidade do Parfor e do Sinaes para cursos de pedagogia que apontavam sentidos contrários ou excludentes entre si; ii) ambiguidade dialética, validando-se a relação estabelecida entre os referidos critérios, quando apresentaram mais de um sentido, tendo em vista a própria ambiguidade da natureza humana que pode produzir situações ou fatos que podem ser ambivalentes, e por isso mesmo resultar em imprecisões; iii) reciprocidade de perspectivas, considerando aspectos subjacentes à relação investigada que não admitem separação ou categorização por fazer parte de uma totalidade ${ }^{14}$; iv) complementaridade dialética, destacando-se a possibilidade de resolver a contrariedade entre elementos pela junção de aspectos diversos pela sua compensação, refletindo posições intermediárias de características opostas, o encaixe de elementos que se completam, ou o fortalecimento de posições, ora em uma direção, ora em direção contrária; e v) polarização dialética, considerando-se as direções opostas ou excludentes entre elementos contrários, mas que o método hiperempirista dialético tendeu a analisar por meio das demais relações dialéticas consideradas. Dessa forma, as diretrizes de análise permitiram que as bases do hiperempirismo dialético se expressassem na apropriação das referências advindas das áreas de políticas públicas, avaliação da educação superior e formação de professores, relacionando-as com a realidade estudada para evidenciar o objeto de pesquisa, sua problematização e um permanente abrir-se ao improvável durante o caminho em busca de resposta para a questão de pesquisa formulada.

Esse exercício de uso dos procedimentos operatórios do hiperempirismo dialético instigou um permanente questionamento teórico para a "demolição de todos os conceitos adquiridos e cristalizados, com vistas a impedir a mumificação destes" (GURVITCH, 1987, p. 22). Conforme orientação presente no método, os fenômenos sociais estão em permanente transformação e, portanto, devem ser observados de forma a contemplar as mudanças inerentes à natureza do seu criador. Segundo Gurvitch (1987), a análise dos fenômenos sociais precisa contemplar o fato de que estes são modificados pelos atos, ações, juízos, contexto e pelo aparato humano de uma forma dinâmica. Nesse sentido, a tentativa de aproximação desta análise às recomendações presentes no método escolhido provocou certa

\footnotetext{
${ }^{13}$ Esses conceitos compreendem as categorias do método escolhido e foram destacados em itálico ao longo do texto. Em alguns trechos, as definições das categorias do método serão relembradas em notas de rodapé para facilitar a aproximação do leitor ao seu significado.

${ }^{14}$ A título de ilustração, a reciprocidade de perspectiva foi visualizada neste trabalho como na figura taoista yinyang, que expõe forças opostas e complementares que não podem ser separadas.
} 
problematização em torno da definição de objetivos como estratégias para o desenvolvimento da pesquisa.

A definição de objetivos é uma estratégia largamente utilizada para organizar as investigações científicas, uma vez que estabelecem pontos que se pretendeu atingir ao responder o problema de pesquisa e, de forma regressiva, organiza os procedimentos operacionais de coleta e análise de dados. Porém, tal estratégia se mostrou pouco adequada neste estudo. O método hiperempirista dialético sinalizou fortemente que as pessoas e grupos diretamente envolvidos com as questões em torno da formação de professores interferem ativamente na realidade, fazendo com que o padrão de qualidade estabelecido pela síntese dos critérios usados por Parfor e do Sinaes, respectivamente, para a oferta e a avaliação dos cursos de pedagogia, como produto de suas ações, fosse entendido como uma experiência não acabada. Essa dinamicidade dificultou a fixação prévia de alvos para guiar a condução da investigação. As tentativas empreendidas ao longo do percurso de se fazer uma definição $a$ priori daquilo que seria alcançado se mostraram pouco efetivas. Os objetivos estabelecidos para orientar a análise dos dados foram ressignificados pelos procedimentos operatórios do hiperempirismo dialético, culminando com a redefinição constante desses objetivos para permitir que a realidade empírica fosse adequadamente evidenciada, não por alvos idealizados, mas por aquilo que representou de fato. O que se vivenciou no decorrer deste estudo foi a (re)construção permanentemente dos supostos alvos a serem alcançados na tentativa de evitar a sua descontextualização epistemológica pela parcialidade e/ou falta de criticidade.

Considerando, então, que a realidade empírica, à medida que se apresentava, requeria ajustes e rearranjos constantes dos objetivos de pesquisa, as diretrizes de análise se mostraram úteis, também, como estratégia efetivas de operacionalização do estudo. Elas tornaram transparentes as discussões teórica e empírica, coordenando-as em torno da construção do objeto de pesquisa, bem como das respostas provisórias que instrumentalizaram a coleta e a análise dos dados. Dessa forma, no exercício da pesquisa, enquanto as diretrizes exerceram o papel de subsídio às tentativas de construção teórico-empírica na busca da totalidade sistêmica inerente ao hiperempirismo dialético, os objetivos sintetizaram os principais resultados dessas construções. Por isso, arriscou-se reconhecer que o real alcance dos resultados da pesquisa só pôde ser delineado ao final do processo de análise teórico-empírica, conforme sinalizado a seguir: 
a) Objetivo geral: analisar a relação estabelecida entre os critérios de qualidade existentes na oferta de licenciaturas presenciais em pedagogia pelo Parfor e aqueles utilizados pelo Sinaes para avaliar esse tipo de curso.

b) Objetivos específicos:

b1) analisar os critérios de qualidade utilizados pelo Sinaes para avaliar os cursos presenciais de pedagogia oferecidos no Brasil.

b2) analisar os critérios de qualidade existentes nos cursos presenciais de pedagogia do Parfor, no contexto da regulação exercida pelo Sinaes sobre a qualidade desses cursos.

b3) identificar o padrão de qualidade assumido pelo governo brasileiro em prol da adequada formação inicial de professores da educação infantil e dos anos iniciais do ensino fundamental.

Para se chegar aos dados que viabilizaram a construção dos resultados sinalizados por esses objetivos, partiu-se das diretrizes de análise, visando identificar as categorias analíticas a elas associadas, bem como as fontes de informações empíricas capazes de oferecer os elementos necessários à discussão proposta, conforme Tabela 1.

Tabela 1 - Diretrizes de análise, categorias analíticas e fontes de informação para coleta de dados.

\begin{tabular}{|c|c|c|}
\hline Diretrizes de análise & Categorias analíticas $^{1}$ & Fontes de Informação \\
\hline \multirow{3}{*}{$\begin{array}{l}\text { (Não)ações, omissões e } \\
\text { embates da Política de } \\
\text { Qualidade. }\end{array}$} & Embates & \multirow{3}{*}{$\begin{array}{l}\text { Atas das reuniões do Conselho Técnico- } \\
\text { Científico da Educação Básica (CTC-EB). }\end{array}$} \\
\hline & (Não) ações & \\
\hline & Omissões & \\
\hline \multirow{2}{*}{$\begin{array}{l}\text { Conceito e concepções de } \\
\text { qualidade na educação } \\
\text { superior. }\end{array}$} & Conceito de qualidade & \multirow{2}{*}{$\begin{array}{l}\begin{array}{l}\text { Entrevistas com coordenadores de cursos } \\
\text { presenciais de pedagogia, primeira } \\
\text { licenciatura, do Parfor. }\end{array} \\
\text { Atas das reuniões do Conselho Técnico- } \\
\text { Científico da Educação Básica. }\end{array}$} \\
\hline & Uso dos resultados da avaliação & \\
\hline \multirow{3}{*}{$\begin{array}{l}\text { Critérios de qualidade para } \\
\text { oferta e regulação dos } \\
\text { cursos de pedagogia. }\end{array}$} & Organização didático-pedagógica & \multirow{3}{*}{$\begin{array}{l}\text { Entrevistas com coordenadores de cursos } \\
\text { presenciais de pedagogia, primeira } \\
\text { licenciatura, do Parfor. } \\
\text { Relatórios divulgados pelo Sinaes sobre o CPC } \\
\text { dos cursos de pedagogia e relatórios de } \\
\text { avaliações in loco realizadas nesses cursos. }\end{array}$} \\
\hline & Corpo Docente & \\
\hline & Infraestrutura & \\
\hline
\end{tabular}

Fonte: Elaborado pela autora com base no marco teórico da pesquisa e na configuração empírica do objeto.

${ }^{1}$ Denomoniação estabelecida com base em Minayo (2013).

Conforme explicou Minayo (2013, p.357), a construção do dado não pode ser considerada como produto exclusivo do campo empírico, uma vez que "traz em seu interior 
uma construção de indagações e respostas". Para a autora, o dado só existe como informação relevante quando são formuladas previamente perguntas de pesquisa e hipóteses investigativas. No caso desta pesquisa, foram as diretrizes de análise, e não os objetivos de pesquisa, que terminaram por organizar o desenvolvimento da investigação ao orientarem a construção dos instrumentos de coleta e análise de dados. Foi com base nas principais categorias analíticas, definidoras das diretrizes de análise, que se buscaram os indicativos de respostas à pergunta de pesquisa.

Nesse sentido, as fontes desses dados foram localizadas a partir de três tipos de populações: a primeira, formada pelos coordenadores de cursos presenciais de pedagogia do Parfor com bolsas ativas; a segunda, relativa às atas das reuniões do CTC-EB; e a terceira, formada pelos documentos gerados pelo Sinaes sobre a avaliação de cursos de pedagogia (visitas in loco e indicadores de qualidade). A partir delas, procedeu-se à coleta de dados por meio de amostras representativas de coordenadores de curso presenciais de pedagogia do Parfor e de relatórios das visitas in loco realizadas pelo Sinaes, mais bem detalhada na seção 3.1 deste trabalho.

Cabe esclarecer que os projetos pedagógicos não foram tomados como fonte de informação para a caracterização dos cursos, complementando as informações trazidas por seus coordenadores, pelo entendimento de que poderiam se constituir como uma "carta de intenções" sem representar a qualidade refletida na prática dos cursos, requerida pela pergunta de pesquisa. Inclusive, em alguns casos, as entrevistas terminaram por apontar para um projeto pedagógico em construção, sendo resolvido e ajustado conforme as necessidades do curso, notadamente em relação aos estágios e às dificuldades dos alunos com a produção e interpretação de textos ou mesmo à microinformática.

No que se referiam às demais possibilidades de fontes de informação, tais como entrevista com membros do CTC-EB, gestores do Inep - órgão responsável pelo Sinaes - e da Capes - responsável pelo Parfor - ou até mesmo com avaliadores participantes do sistema nacional de avaliação, entendeu-se que: i) os embates que ocorreram durante o processo de formulação e implementação da política de formação de professores em nível federal estariam mais bem retratados em registros históricos realizados enquanto o processo se desenvolvia, inclusive pelos próprios filtros decorrentes de tais embates, refletidos nas sínteses documentadas; e ii) os critérios de qualidade utilizados pelos avaliadores estariam contemplados de forma mais sistematizada nos relatórios de visitas avaliativas, entendendo-se ser mais rico considerar os registros contextualizados sobre tais critérios no âmbito do próprio Sinaes. 
Em relação às atas disponíveis (aprovadas), que registraram o conteúdo das reuniões do CTC-EB no período compreendido entre a instalação do conselho (fevereiro de 2008) e a fase de coleta de dados desta pesquisa (abril de 2013), todas elas foram consideradas. Essas atas foram solicitadas à Capes por meio do Serviço de Informação ao Cidadão, da Controladoria Geral da União, e foram recebidas por meio de arquivo anexado a uma mensagem de correio eletrônico. A mensagem recebida continha 25 arquivos em formato “.pdf”, já numerados cronologicamente de 1 a 25. Contudo, computaram-se apenas 24 documentos distintos, uma vez que a ata identificada como de número 10 tinha o mesmo conteúdo daquela de número 12 . No seu conjunto, essas atas foram integralmente analisadas por sintetizarem as discussões do Conselho, não se estabelecendo amostras desses documentos em função da sequência de raciocínio e por sua quantidade relativamente pequena.

O material coletado foi codificado da seguinte forma: i) atas, mantendo-se a numeração sequencial que receberam, conforme ordem de realização das reuniões do CTCEB; ii) entrevistas, identificando-se os coordenadores por meio de letras representativas de suas IES; e iii) relatórios das avaliações in loco, por números identificadores das IES, sem que fosse obedecida uma ordem específica. Na sequência, analisaram-se os dados coletados.

Buscando manter a consonância da pesquisa com os princípios epistemológicos que a sustentou, foi utilizada a hermenêutica como técnica para tratamento e análise dos dados qualitativos. Segundo Minayo (2013), a articulação entre a dialética e a hermenêutica se dá pela complementaridade. Enquanto a primeira critica e contesta, a segunda procura esclarecer e compreender. Para a autora (p. 168), a dialética precisa da hermenêutica para assimilar as contradições da linguagem, indicando que "a hermenêutica-dialética constitui um importante caminho do pensamento para fundamentar pesquisas qualitativas".

Dentro dessa perspectiva, procedeu-se, em linhas gerais, leitura flutuante para maior aproximação dos dados; preparação de planilha eletrônica com dados de contexto, ${ }^{15}$ com as categorias analíticas de cada conjunto dos dados e com as categorias empíricas previamente identificadas na leitura flutuante; classificação dos trechos mais relevantes de acordo com as categorias previamente levantadas, à medida que as próprias categorias iam sendo aperfeiçoadas; realização de leitura transversal em cada planilha de dados, na qual cada

15 Informações sobre localização geográfica das IES, características institucionais dos cursos e seus resultados obtidos nos indicadores de qualidade do Sinaes, formação acadêmica e experiência profissional dos coordenadores, etc. 
subconjunto de dados categorizados foi contrastado entre si e com os demais, seguida da análise final. Como resultado, os dados evidenciaram que:

a) no contexto da Política de Qualidade, as disputas em torno das competências da Capes/ CTC-EB e suas interações com as competências de outros órgãos do MEC na condução da política de formação de professores remeteram de forma incondicional e acrítica a garantia do padrão de qualidade do Parfor aos critérios de qualidade do Sinaes, apesar das limitações deste último no alcance dos arranjos envolvidos para oferta dos cursos de formação inicial de professores pelo primeiro;

b) a qualidade da formação do pedagogo no Brasil revelada pelo Sinaes tem padrões pouco claros, dificultando a identificação dos perfis de qualidade dos cursos em relação aos cinco níveis da escala do sistema avaliativo, bem como o entendimento sobre o que se espera de um bom curso de pedagogia no Brasil;

c) adicionalmente, as características de qualidade apresentadas pelos cursos do Parfor não refletiram um padrão de qualidade minimamente compartilhado, seja em função do tipo de balizamento oferecido pelas DCN do curso, seja em razão das imprecisões e da baixa afiliação aos critérios de qualidade do Sinaes como padrão de qualidade a ser seguido;

d) por fim, os critérios utilizados pelo Parfor, na oferta de licenciaturas presenciais de pedagogia, e pelo Sinaes, na avaliação desse tipo de curso, evidenciaram uma relação de ambiguidade, sem que fosse possível saber ao certo os parâmetros que balizam o padrão de qualidade da formação inicial de professores da educação infantil e dos anos iniciais do ensino fundamental.

Para demonstrar esses achados, este texto foi organizado em quatro capítulos, de forma a proporcionar acercamentos sucessivos à análise do objeto da pesquisa. Assim, nesta introdução, seguiu-se a lógica de aproximação mais geral ao tema e das definições metodológicas assumidas no decurso da pesquisa. Já nos demais capítulos, procurou-se aprofundar as ideias inicialmente trabalhadas.

No capítulo 1, discutiram-se o contexto histórico e o delineamento legal e empírico, que permitiram configurar como pressuposto a existência de uma Política de Qualidade, subjacente às ações do Parfor e do Sinaes, respectivamente, na oferta na avaliação de cursos de pedagogia. Também se destacou a fundamentação teórica advinda da área de políticas públicas que deram sustentação ao entendimento sobre a existência (de fato) dessa política. Adicionalmente, apresentaram-se de forma mais detalhada os elementos considerados basilares da Política de Qualidade: o Parfor, o Sinaes e as DCN da licenciatura em pedagogia. 
No capítulo 2, discutiu-se conceitualmente a qualidade como constructo de pesquisa, bem como os conceitos operacionais de critérios, indicadores e parâmetros que levaram a um aprofundamento de características consideradas como boas ou adequadas para a oferta e avaliação de cursos de formação de professores. Essas discussões forneceram as bases teóricas necessárias para a coleta e para a discussão dos principais achados empíricos da pesquisa.

No capítulo 3, detalhou-se o caminho percorrido para a identificação dos critérios de qualidade assumidos pelo Parfor e pelo Sinaes, respectivamente, na oferta e na de cursos de pedagogia. Esses critérios foram identificados na realidade empírica a partir das referências consideradas principalmente no capítulo 2 desta tese, contemplando aspectos vinculados às dimensões: organização didático-pedagógica, corpo docente e infraestrutura. Procurou-se, nessa análise, privilegiar a articulação teórico-empírica, bem como mecanismos que pudessem permitir a comparação entre os critérios de qualidade identificados.

No capítulo 4, evidenciaram-se os embates, (não)ações e omissões que caracterizaram a Política de Qualidade latente à relação investigada, bem como o padrão de qualidade dela decorrente. Os dados analisados confirmaram a hipótese de desconexão ou, mais precisamente, ambiguidade entre os critérios de qualidade utilizados pelo Parfor e pelo Sinaes, respectivamente, na sua dinâmica de oferta e avaliação de cursos de pedagogia. Em termos epistemológicos, a ambiguidade encontrada foi associada à possibilidade de os elementos de uma mesma totalidade se comportar de forma ambivalente, validando sentidos diferenciados. Com isso, no caso estudado, inferiu-se que tal ambivalência reforçou o caráter impreciso dos indicadores e parâmetros difundidos por Parfor e Sinaes nas suas ações em torno de cursos de licenciatura em pedagogia, fazendo com que o padrão de qualidade resultante pouco esclareça sobre o que é qualidade para esses cursos. No contexto dessas imprecisões, discutiu-se, ainda nesse capítulo, a concepção de qualidade que vem orientando a formação do pedagogo no Brasil e a sua repercussão prática.

Concluindo o trabalho, nas considerações finais, buscou-se ressaltar os principais argumentos abordados ao longo dos capítulos para sustentar a tese de que o padrão de qualidade emanado (de fato) pelo governo brasileiro para orientar a formação inicial de professores da educação infantil e dos anos iniciais do ensino fundamental, por meio de suas ações no Parfor e no Sinaes, é impreciso. A partir dessa tese, foram apresentadas, ainda, reflexões visando contribuir para a superação da imprecisão identificada. Em linhas gerais, argumentou-se que os embates de interesses em torno das ações de governo no campo da formação de professores e da qualidade da educação superior, bem como as (não)ações e 
omissões decorrentes desses embates, fizeram emergir, explicitamente, relações ambíguas entre os critérios de qualidade do Parfor e do Sinaes, respectivamente, para a oferta e a avaliação de cursos de pedagogia. Subjacente a essas relações, emergiu também a Política de Qualidade para a Formação Inicial de Professores da Educação Infantil e dos Anos Iniciais do Ensino Fundamental, configurada à revelia de documento legal, corpo burocrático ou dotação orçamentária, mas que vem orientando, de fato e imprecisamente, a qualidade de cursos de pedagogia no País. 



\section{POLÍTICA DE QUALIDADE PARA A FORMAÇÃO INICIAL DE PROFESSORES DA EDUCAÇÃO INFANTIL E DOS ANOS INICIAIS DO ENSINO FUNDAMENTAL}

Neste primeiro capítulo, discutiu-se o pressuposto da existência da Política de Qualidade para a Formação Inicial de Professores da Educação Infantil e dos Anos Iniciais do Ensino Fundamental. Para tanto, apresentou-se o contexto histórico a partir do qual ela se delineou, bem como os aspectos legais e empíricos da sua configuração. Analisou-se, ainda, a relação Estado-sociedade, buscando subsídios teóricos para justificar os pontos de articulação ente o Parfor, Sinaes e as DCN da licenciatura em pedagogia como política pública específica.

\subsection{CONTEXTO HISTÓRICO DE EMERGÊNCIA DA POLÍTICA QUALIDADE}

A década de 1990 representou para o Brasil, no campo econômico, a abertura de mercados e o fortalecimento da inserção do país no mundo interconectado. No campo das políticas públicas voltadas à educação, representou o despertar para a necessidade de ampliação/universalização do acesso da população à educação de qualidade, impulsionado por movimentos dos organismos internacionais e das organizações produtivas. Esses movimentos emergiram mais fortemente em meados dos anos 1970, quando os arranjos taylorista e fordista começaram a ceder lugar ao chamado modelo toyotista de produção, ${ }^{16}$ impulsionados pelo contexto de incerteza que passou a dominar o panorama produtivo mundial. Nesse ambiente, a globalização dos mercados, a flexibilização da produção, o acirramento da competição e a intensificação do uso de novas tecnologias para comunicação, produção e gestão formaram um ciclo de causa e consequência que vem provocando, ainda hoje, mudanças na estrutura de organizações, nações e no comportamento dos indivíduos (HARVEY, 1992; MELLO, 1991).

Tal ambiente de mudança vem exigindo dos trabalhadores comportamentos inovadores e agilidade na superação de desafios das instituições de que fazem parte. Nesse

\footnotetext{
${ }^{16}$ A partir das contribuições de Antunes (1995) e de Rago e Moreira (1984), entendeu-se taylorismo, fordismo e toyotismo como modelos de racionalização do trabalho que se diferenciam pela visão de homem e pelas práticas de gestão utilizadas. O homem taylorista, limitado, é incapaz de se responsabilizar por sua tarefa. Nesse sentido, o trabalho é simplificado, disciplinado e acompanhado por um inspetor que garante a sua realização, não sendo necessária uma maior qualificação do executor da tarefa. Já o homem fordista não precisa do acompanhamento ostensivo do inspetor, os métodos são mais sutis - a esteira rolante garante o fluxo da produção. Investe-se, então, na motivação (salários e benefícios). No toyotismo, a necessidade de customização de produtos e serviços, bem como de uma constante inovação, traz à cena a mobilização do saber operário. As tarefas não são tão simples quanto no taylorismo ou no fordismo. O trabalhador torna-se polivalente, parceiro, criativo, responsável pelo seu grupo de trabalho e preocupado com a excelência produtiva, exigindo-se dele, portanto, níveis maiores de qualificação para a realização de sua tarefa.
} 
contexto, estabeleceram-se as preocupações mais recentes com as questões educacionais no Brasil, visando à formação de quadros necessários à sustentação do novo paradigma do capitalismo mundial.

No relatório "Educação para todos: avaliação da década" (INEP, 2000), o governo brasileiro preferiu destacar, no entanto, a centralidade da educação dentro das políticas públicas nos termos propostos pela conferência promovida pela Organização das Nações Unidas para a Educação, a Ciência e a Cultura (Unesco) em Jomtien, Tailândia, no ano de 1990, que reforçou a educação como direito fundamental da pessoa humana, visando à inserção e sobrevivência em um mundo cada vez mais dependente de informação. Nessa conferência, o Brasil assumiu o compromisso previsto na "Declaração Mundial sobre Educação para Todos: satisfação das necessidades básicas de aprendizagem" de tornar universal a educação básica, ampliando oportunidades de aprendizagem para crianças, jovens e adultos (UNESCO, 1990). Esse compromisso foi reafirmado pelo País em 1993 pela "Declaração de Nova Delhi sobre Educação para Todos" (UNESCO, 1993).

Na sequência, o Fórum Mundial de Educação, realizado em abril de 2000, na cidade de Dakar, Senegal, trouxe à tona a questão da qualidade e, não tão somente, do acesso. No marco de ação "Educação para Todos - O Compromisso de Dakar" (UNESCO, 2000), também subscrito pelo Brasil como país-membro da Unesco, a qualidade da educação e a consequente aferição de resultados mensuráveis tornaram-se um dos objetivos a serem declaradamente perseguidos.

O Plano de Metas Compromisso Todos pela Educação (Compromisso), publicado por meio do Decreto n. ${ }^{\circ}$ 6.094, de 24 de abril de 2007 (BRASIL, 2007b), explicitou a aderência do governo brasileiro às orientações do fórum de Dakar. No âmbito desse documento legal, foram viabilizadas adesões voluntárias dos entes federados ao Compromisso por meio de Planos de Ações Articuladas (PAR), assegurando recursos financeiros para ações voltadas à melhoria da qualidade da educação. Adicionalmente, foram criados o Índice de Desenvolvimento da Educação Básica (Ideb) ${ }^{17}$ e a assistência técnica da União aos municípios e estados brasileiros para promoverem reflexões sobre necessidades, aspirações, demandas e prioridades educacionais a serem alcançadas.

O referido decreto estabeleceu, ainda, entre outros focos de atuação, a instituição de ações para formação inicial e continuada de profissionais da educação. Com isso, tais ações

\footnotetext{
${ }^{17}$ Indicador criado para medir a qualidade de cada escola e de cada rede de ensino. É calculado a partir do desempenho do estudante na Prova Brasil e em taxas de aprovação, servindo como medida da qualidade esperada para o ensino básico.
} 
foram destacadas do PAR para instituir um programa de formação de docentes em larga escala entre os entes federados, o Parfor.

A partir de julho de 2009, os cursos de formação sob a chancela do Parfor começaram a receber professores das redes municipais e estaduais de educação básica. Em janeiro de 2012, os dados apurados pelo sistema que gerencia o Plano (Plataforma Freire) revelaram a matrícula de 42.096 professores em formação, distribuídos em um total de 3.177 turmas, conforme Gráficos 1 e 2 a seguir.

Gráfico 1 - Oferta de turmas dos cursos do Parfor - janeiro/2012 (Brasil).

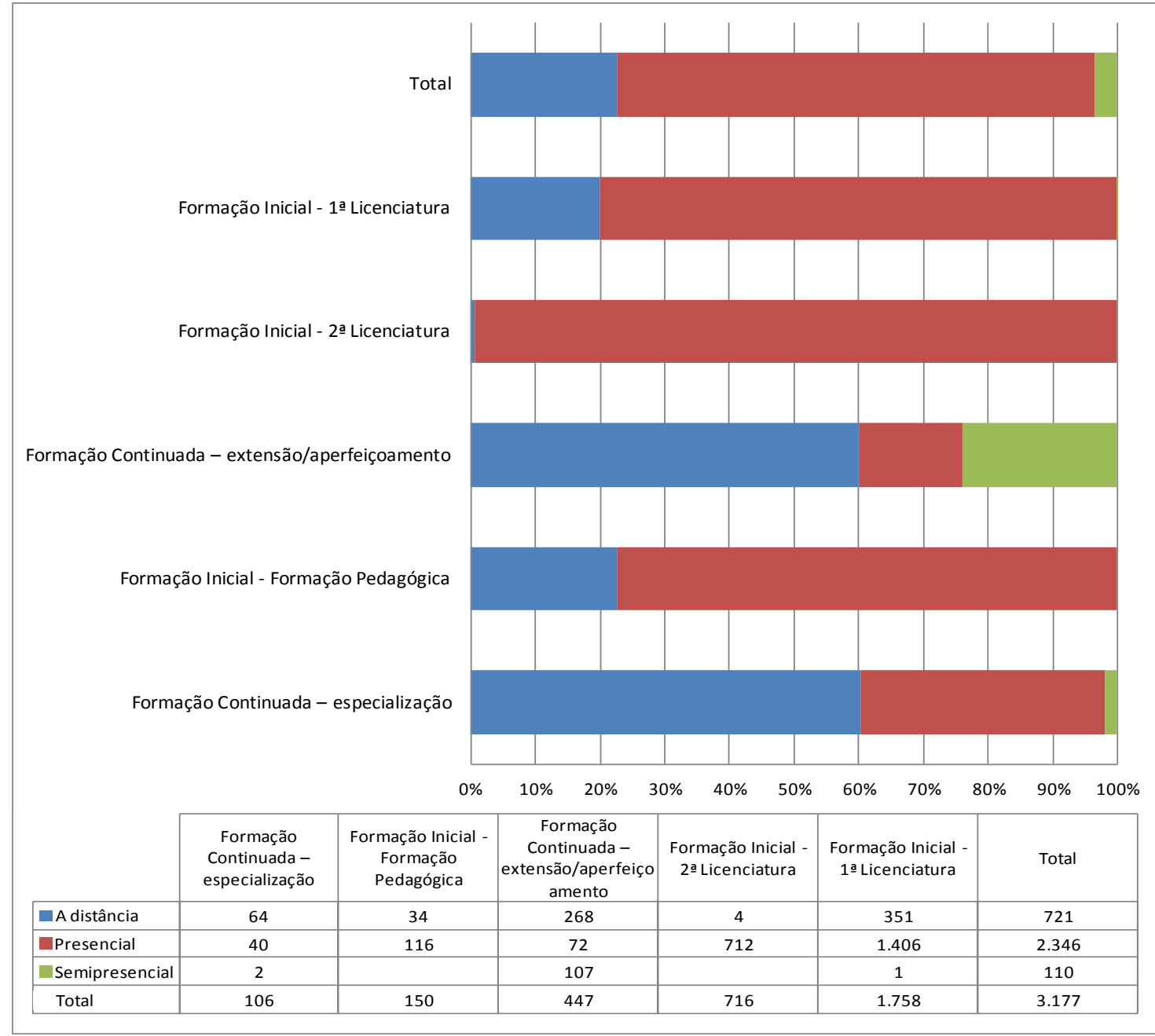

Fonte: Diretoria de Educação Básica/Capes (Plataforma Freire).

Especificamente sobre o Gráfico 1, os dados apontaram que quase $80 \%$ das turmas do Parfor foram oferecidas na modalidade presencial, seguindo as orientações legais contida na política de formação docente (BRASIL, 2009). No que se referiram às matrículas, as informações sistematizadas no Gráfico 2 sinalizaram o perfil do Parfor como voltado à 
presencial de docentes - cerca de $90 \%$ do total de 42.096 matrículas -, notadamente em cursos de primeira licenciatura $-85 \%$ do total de matrículas.

Gráfico 2 - Número de alunos matriculados no Parfor - janeiro/2012 (Brasil).

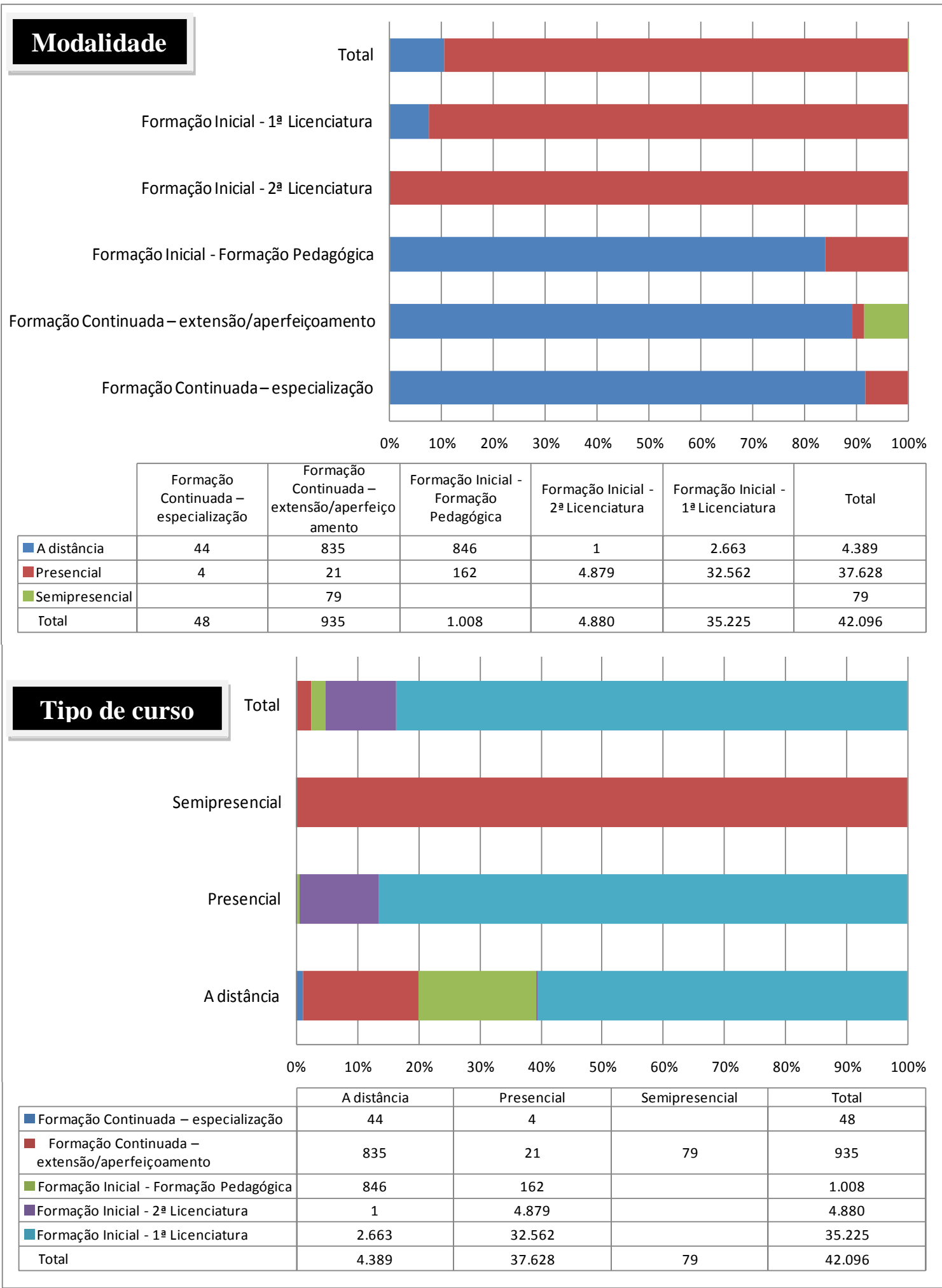

Fonte: Diretoria de Educação Básica/Capes (Plataforma Freire) 
Ainda segundo os dados presentes no Gráfico 2, os cursos a distância só superaram os presenciais na oferta da Formação Pedagógica e da formação continuada extensão/aperfeiçoamento. Porém, esses cursos responderam, apenas, por cerca de $5 \%$ das matriculas do Parfor. No que se referiu ao perfil dos cursos a distância, cerca de $60 \%$ das matrículas ocorreram na formação em primeira licenciatura, seguida das matrículas na formação pedagógica e nos cursos de extensão/aperfeiçoamento, com pouco menos de $20 \%$ cada uma.

Vale ressaltar que os dados sistematizados nos Gráficos 1 e 2 expuseram as limitações operacionais da Plataforma Freire. A título de ilustração, foi possível observar que o número de matriculados em cursos semipresenciais era menor que o de turmas cadastradas no sistema. Além disso, de acordo com os dados fornecidos pela Capes, existiria um único aluno matriculado em cursos de segunda licenciatura a distância, apesar de terem sido oferecidas, em tese, quatro turmas. De toda forma, ainda que pouco precisos, os dados permitiram mostrar a vocação do Parfor para atender à formação inicial em primeira licenciatura de professores da educação básica em nível superior, na modalidade presencial.

$\mathrm{Na}$ Tabela 2, detalharam-se as áreas nas quais os alunos de cursos de primeira licenciatura presencial foram matriculados. Conforme foi possível apurar, quase $40 \%$ dessas matrículas foram realizadas em cursos de pedagogia, demonstrando a importância dessa área, em particular, na oferta de cursos pelo Parfor.

Tabela 2 - Número de matrículas do Parfor Presencial em $\operatorname{cursos}^{1}{ }^{1}$ e primeira licenciatura - janeiro/2012.

(Brasil).

(continua)

\begin{tabular}{|c|c|c|c|}
\hline & & Matrículas & $\%$ \\
\hline & Total & 32.562 & $100,0 \%$ \\
\hline Pedagogia & & 12.716 & $39,1 \%$ \\
\hline Letras & & 3.507 & $10,7 \%$ \\
\hline Matemática & & 2.500 & $7,7 \%$ \\
\hline História & & 2.400 & $7,4 \%$ \\
\hline Biologia & & 2.171 & $6,7 \%$ \\
\hline Informática & & 1.753 & $5,4 \%$ \\
\hline Educação física & & 1.713 & $5,3 \%$ \\
\hline
\end{tabular}




\begin{tabular}{|c|c|c|}
\hline Curso & Matrículas & $\%$ \\
\hline Geografia & 1.634 & $5,0 \%$ \\
\hline Artes & 1.072 & $3,3 \%$ \\
\hline Ciências & 597 & $1,8 \%$ \\
\hline História e Geografia & 564 & $1,7 \%$ \\
\hline Ciências Sociais & 522 & $1,6 \%$ \\
\hline Física & 403 & $1,2 \%$ \\
\hline Educação Especial & 233 & $0,7 \%$ \\
\hline Ciências da Religião & 186 & $0,6 \%$ \\
\hline Química & 181 & $0,6 \%$ \\
\hline Filosofia & 178 & $0,5 \%$ \\
\hline Educação do Campo & 168 & $0,5 \%$ \\
\hline Educação Indígena & 34 & $0,1 \%$ \\
\hline Ciências Matemáticas e Linguagens & 29 & $0,1 \%$ \\
\hline
\end{tabular}

Fonte: Diretoria de Educação Básica/Capes (Plataforma Freire).

${ }^{1}$ Cursos agrupados por área pela autora, tendo como referência seus nomes originais.

Tal centralidade, por um lado, justificou a escolha da área de pedagogia como recorte para esta investigação e, por outro, instigou, no âmbito deste histórico, o questionamento do porque dela ocorrer. Na tentativa, então, de identificar possíveis motivos que levaram a uma concentração da oferta do Parfor em cursos de formação inicial, notadamente na pedagogia, recorreu-se a mais recente Sinopse Estatística do professor da educação básica disponível.

Os dados disponíveis foram sistematizados na Tabela 3 e apontaram que, em 2009, apenas 59\% dos professores dos anos iniciais do ensino fundamental e $47 \%$ da educação infantil eram licenciados. Em contrapartida, nos anos finais do ensino fundamental e no ensino médio esse índice girava em torno de $87 \%$. Nesse sentido, a concentração da oferta do Parfor em cursos de pedagogia pareceu uma tentativa de atenuar a carência mais expressiva de professores licenciados nos primeiros anos da educação básica, enquanto que, no seu conjunto, as ações de formação inicial do Parfor, procuraram atender ao exigido pela vigente Lei de Diretrizes e Bases da Educação Nacional (LDB) (BRASIL, 1996). 
Tabela 3 - Distribuição dos professores da educação básica por nível de formação e níveis de ensino em que atuam - 2009 (Brasil).

\begin{tabular}{|c|c|c|c|c|c|c|c|c|c|c|}
\hline \multirow{3}{*}{$\begin{array}{c}\text { NÍVEL DE } \\
\text { FORMAÇÃ̃O }\end{array}$} & \multicolumn{8}{|c|}{ NÍVEL ESCOLAR DE ATUAÇÃO } & \multirow{2}{*}{\multicolumn{2}{|c|}{ TOTAL $^{2}$}} \\
\hline & \multicolumn{2}{|c|}{ Infantil $^{1}$} & \multicolumn{2}{|c|}{$\begin{array}{l}\text { Fundamental - } \\
\text { Anos Iniciais }\end{array}$} & \multicolumn{2}{|c|}{$\begin{array}{c}\text { Fundamental - } \\
\text { Anos Finais }\end{array}$} & \multicolumn{2}{|c|}{ Ensino Médio } & & \\
\hline & $\%$ & $\mathbf{N}$ & $\%$ & $\mathbf{N}$ & $\%$ & $\mathbf{N}$ & $\%$ & $\mathbf{N}$ & $\%$ & $\mathbf{N}$ \\
\hline Licenciados & $47 \%$ & 353.014 & $59 \%$ & 427.795 & $76 \%$ & 596.614 & $87 \%$ & 403.283 & $64 \%$ & 1.264 .949 \\
\hline Total & $100 \%$ & 755.580 & $100 \%$ & 721.513 & $100 \%$ & 783.194 & $100 \%$ & 461.542 & $100 \%$ & 1.977 .978 \\
\hline Fundamental & $1 \%$ & 10.067 & $1 \%$ & 4.137 & $0 \%$ & 3.306 & $0 \%$ & 361 & $1 \%$ & 12.480 \\
\hline Médio & $50 \%$ & 379.892 & $38 \%$ & 275.293 & $22 \%$ & 165.193 & $9 \%$ & 39.703 & $29 \%$ & 624.320 \\
\hline Superior & $48 \%$ & 365.621 & $61 \%$ & 442.083 & $78 \%$ & 614.695 & $91 \%$ & 421.478 & $70 \%$ & 1.341 .178 \\
\hline
\end{tabular}

Fonte: Inep/Sinopse Estatística do Professor da Educação Básica, 2009 (INEP, [2009?b]).

Nota: $\mathrm{N}=$ número de professores

${ }^{1}$ Inclui a creche e a pré-escola

${ }^{2}$ Professores são contados uma única vez em cada etapa/modalidade de ensino e em cada Unidade da Federação, mas podem atuar em mais de uma etapa/modalidade de ensino e em mais de uma UF. Por isso, o número total de professores não corresponde à soma das totalizações por nível escolar de atuação. Nesse total, estão incluídos os professores da educação especial, educação profissional e de jovens e adultos, não detalhados nas colunas anteriores.

No quadro geral da oferta presencial dos cursos de pedagogia no Brasil, os dados do Gráfico 3 demonstraram a ampliação expressiva da oferta desses cursos. Entre os anos de 1995 e 2013, o total de cursos presenciais de pedagogia mais que triplicou, notadamente na esfera privada. A título de comparação, em 1995, o número desses cursos oferecidos por IES privadas era levemente superior aos oferecidos por IES públicas. Em 2013, essa diferença se acentuou, com a oferta privada representando quase o dobro da oferta pública. 
Gráfico 3 - Número de cursos presenciais de pedagogia por categoria administrativa e organização acadêmica - 1995 a 2013 (Brasil).

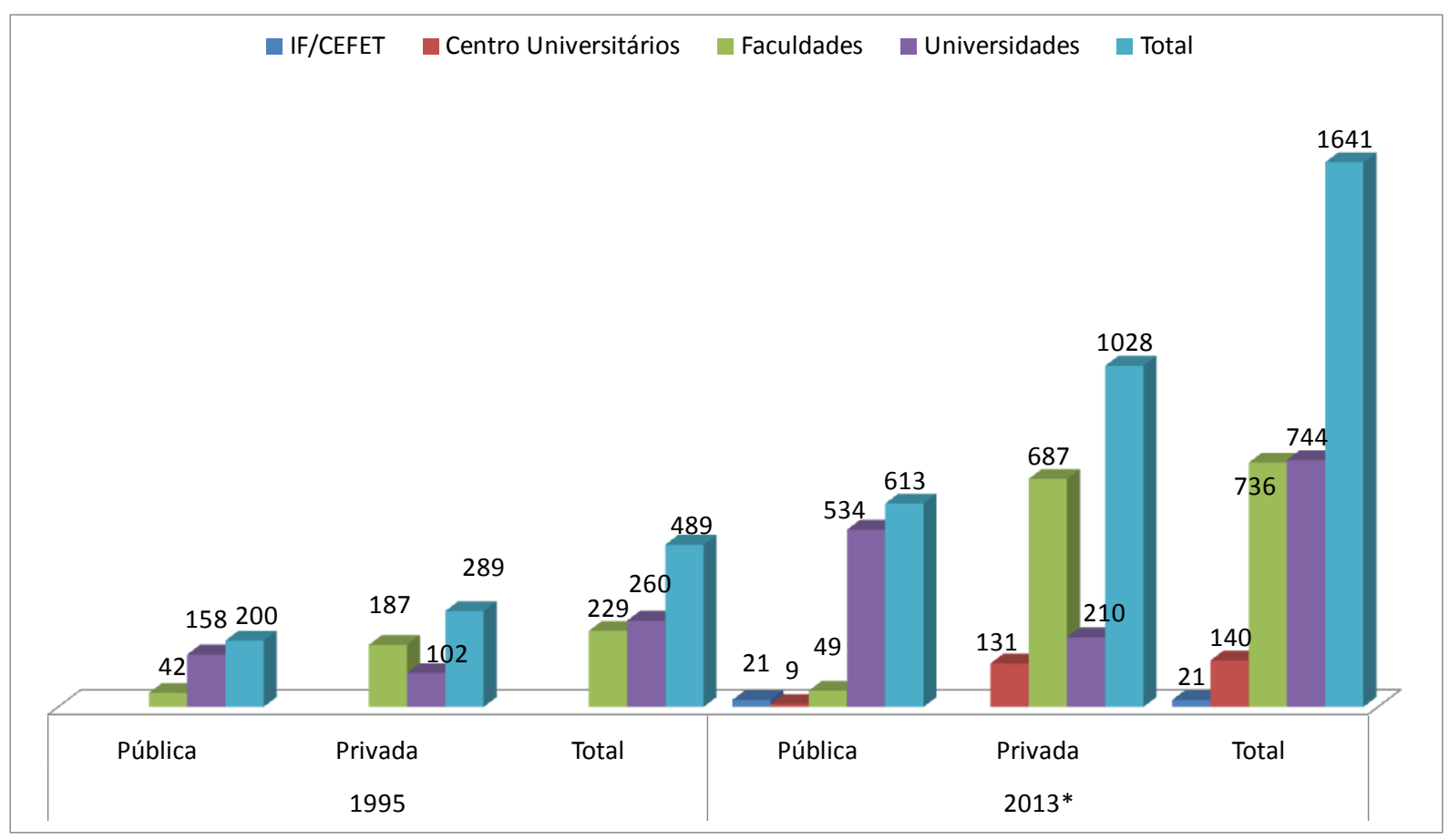

Fonte: Inep/Sinopse Estatística da Educação Superior 1995 (INEP, [1996?]); Inep/Sinopse Estatística da Educação Superior 2012 (INEP, [2014]).

* Dois cursos nomeados Administração educacional (IF/CEFET) e dois nomeados Educação Organizacional (universidade/privada).

Esse movimento de expansão da oferta dos cursos de pedagogia no país acompanhou tendência observada no total dos cursos presenciais de graduação, em geral. Dados das Sinopses Estatísticas da Educação Superior apontaram que em 1995 existiam 6.252 cursos superiores em funcionamento no Brasil, dos quais pouco mais da metade (3.470) eram oferecidos por IES privadas (INEP, [1996?]). Em 2013, esse número subiu para 30.791, dos quais cerca de 70\% (20.447) eram de categoria administrativa privada (INEP, [2014]).

Na visão de Sousa (2003, 2006, 2009, 2013), que analisou a educação superior brasileira do ponto de vista da relação público-privado, o movimento de expansão representado pelos dados apresentados decorreu de ações efetivas do governo brasileiro. Segundo o autor, a Reforma do Estado contribuiu decisivamente para a configuração desse quadro, incentivando o aumento da participação privada nesse nível de educação e, ao mesmo 
tempo, intensificando os processos avaliativos de sua qualidade, seguindo uma perspectiva da accountability. $^{18}$

Essa reforma, amparada pela perspectiva neoliberal exarada pelo Consenso de Washington $^{19}$, foi inspirada no documento Governance in transition: public management reforms in OECD countries (OCDE, 1995) e deu base à ideia de que os serviços educacionais, assim como os do setor de saúde, não são exclusivos do setor público (BRASIL, 1998). Conforme esclareceu Maués (2007), ao definir a educação como um serviço não exclusivo do Estado, a Reforma provocou o aumento no número de cursos de formação superior e imputou ao Estado a necessidade de fixar regras para garantir um padrão mínimo para a qualidade deles. Como consequência, processos avaliativos passaram a ser utilizados para conferir se cursos e IES estavam cumprindo o padrão de qualidade estabelecido para regular a educação superior no País.

Para viabilizar a execução dessa lógica, a Lei n. ${ }^{\circ}$ 9.131, de 24 de novembro de 1995, foi aprovada para garantir a realização de avaliações periódicas das instituições e dos cursos de nível superior (BRASIL, 1995). Essa lei definiu expressamente a necessidade da realização anual de exames nacionais, com base nos conteúdos mínimos então estabelecidos para cada curso, visando avaliar os conhecimentos e competências adquiridos pelos alunos de graduação em fase de conclusão de curso. Assim, por meio desse dispositivo legal criou-se o Exame Nacional de Cursos (ENC), mais conhecido como "Provão".

Durante o período de sua vigência, de 1996 a 2003, o ENC sofreu diversas críticas sobre suas fragilidades como sistema avaliativo, até ser substituído pelo Enade em 2004. Conforme destacou Fonseca (2010), a principal intenção da nova proposta de avaliação de desempenho dos alunos foi tentar neutralizar o efeito competitivo e classificatório do ENC. Adicionalmente, o Enade trouxe uma perspectiva de integração das avaliações de desempenho discentes, de curso e de instituições por meio da organização sistêmica do Sinaes.

Como síntese desse contexto histórico que orientou as discussões desenvolvidas nesta pesquisa, observou-se que tanto a criação do Parfor quanto a do Sinaes estiveram inseridas na esfera de soluções que responderam às preocupações com a qualidade da educação, presentes em documentos difundidos internacionalmente (UNESCO, 1990, 1993, 2000; OCDE, 1995;

18 Considerando a contribuição de Afonso (2013), esse conceito pode ser entendido como prestação de contas dos resultados alcançados pelas organizações. No caso das políticas públicas, pressupõe o acompanhamento dos seus resultados pela sociedade civil.

19 Conjunto de políticas econômicas voltadas ao enfrentamento de déficits fiscais que estavam sendo recomendadas aos países da América Latina pelas instituições financeiras baseadas em Washington D.C. na década de 1990. 
DELORS, 1997). O Parfor evidenciou a necessidade de "promover a melhoria da qualidade da educação básica pública" - conforme definido no inciso I do art. 3..$^{\circ}$ da política de formação docente (BRASIL, 2009a) - utilizando-se, entre outros princípios, da garantia de padrão de qualidade dos cursos oferecidos aos professores. O Sinaes, de acordo o art. $1 .^{\mathrm{o}}$ da Lei n. ${ }^{\circ} 10.861$, de 14 de abril de 2004, que o criou (BRASIL, 2004a), ancorou a busca por melhoria da qualidade da educação superior como um todo e daquela ofertada pelo Parfor, em particular.

Dessa forma, identificou-se que, subjacente às ações do Parfor e do Sinaes, materializaram-se arranjos em prol da qualidade na oferta dos cursos de formação inicial de professores. Tais arranjos, entretanto, não se configuraram formalmente como ações adotadas pelo governo a partir de um documento legal específico, corpo burocrático ou orçamento próprio. Eles emergiram de forma não planejada, definindo um padrão de qualidade para esses cursos. Assim, para uma maior aproximação a esses arranjos, analisou-se nas seções que seguem o ordenamento legal em torno deles, bem como seus desdobramentos empíricos como uma política pública específica.

\subsection{DELINEAMENTO LEGAL E EMPÍRICO}

Tendo como orientação o recorte investigativo desta pesquisa, analisou-se nesta seção o desdobramento das ações do Parfor e do Sinaes em torno da oferta com qualidade de cursos de formação de professores, sob a perspectiva daqueles que têm como campo de atuação a educação infantil e os anos iniciais do ensino fundamental. Nessa perspectiva, as DCN da licenciatura em pedagogia emergiram de forma central nesses desdobramentos, tendo em vista sua competência para orientar tanto a oferta, quanto a avaliação desses cursos.

Conforme definido pelo inciso II do art. 52 da LDB (BRASIL, 1996), as IES devem fixar os currículos dos seus cursos observando diretrizes gerais pertinentes a cada área de referência. Complementarmente, a lei que criou o Sinaes previu a aferição do desempenho dos estudantes em relação aos conteúdos programáticos previstos em tais diretrizes (BRASIL, 2004). Além disso, no desenvolvimento dos seus instrumentos de avaliação de cursos, o Sinaes baseou os seus critérios avaliativos nessas mesmas diretrizes. Com isso, ao ser criado, o Parfor já estava subordinado às DCN tanto sob a perspectiva da oferta dos cursos de formação inicial quanto em relação à avaliação da qualidade dessa oferta por meio do Sinaes.

Porém, embora todo curso de graduação se submeta às regras definidas pelas DCN de sua área formativa, apenas aqueles que fazem parte do Sistema Federal de Ensino Superior 
são regulados com base nos resultados aferidos pelo Sinaes. No caso das licenciaturas oferecidas no âmbito do Parfor por IES estaduais e municipais, os resultados avaliativos aferidos pelo Sinaes sobre elas deixam de ser pré-requisito para abertura de vagas no âmbito do Plano (CAPES, 2014). Adicionalmente, boa parte das vagas oferecidas pelo Parfor para formação dos docentes está vinculada a turmas especiais, as quais nem sempre são alcançadas pelo sistema avaliativo.

Considerando-se, então, que o Sinaes não demonstrou ser capaz de abarcar, sozinho, a responsabilidade sobre o padrão de qualidade definido como princípio pela política de formação docente e ante o pressuposto legal de sua existência (BRASIL, 2009a), propôs-se o entendimento que tal padrão emergira dos critérios de qualidade presentes nas ações do Sinaes, mas também naquelas do próprio Parfor, ao estruturarem, com base nas DCN, características consideradas como adequadas para esses cursos. Com isso, ao ser difundido pelas ações do Parfor e do Sinaes, esse padrão, no caso dos cursos de pedagogia, pareceu materializar (de fato) a Política de Qualidade para a Formação Inicial de Professores da Educação Infantil e dos Anos Iniciais do Ensino Fundamental.

A visão sobre a existência de tal política permitiu entendê-la em uma perspectiva sistêmica, na qual sua totalidade não se confundiu com a simples soma de partes menores, mas, sim, pelas relações estabelecidas entre seus elementos constituintes (Parfor, Sinaes e DCN) em torno da qualidade do curso de pedagogia. Nesse sentido, embora essa política não tenha sido formalmente institucionalizada, a própria natureza das DCN da licenciatura em pedagogia sustentou o entendimento de que ela existe e é distinta dos seus componentes.

A perspectiva desse documento legal de servir de orientação geral às iniciativas formativas das IES não lhe permitiu operacionalizar uma definição de qualidade que atendesse, ao mesmo tempo, a necessidade da política de formação docente estabelecer um padrão para os cursos fomentados nem a necessidade da política de avaliação construir seus instrumentos de medida. Em síntese, essas diretrizes não detalharam aspectos concretos que articulassem claramente o seu entendimento de qualidade às questões práticas da oferta dos cursos de pedagogia sob a chancela do Parfor e das avaliações realizadas pelo Sinaes nessa área de formação. ${ }^{20}$

Nesse sentido, para permitir espaço às iniciativas inovadoras das IES, as DCN balizaram as ações das instituições, sem definir, no entanto, as condições de oferta necessárias

${ }^{20}$ Como exemplo dessas questões práticas podem-se citar a organização de estágios, a definição de tópicos ou áreas de estudos para o desenvolvimento das atividades complementares, além da própria definição do perfil de atuação do egresso. 
à concretização de qualidade desejada. Consequentemente, não ofereceram parâmetros para a estruturação dos processos avaliativos que buscassem aferir, hierarquizar e subsidiar a regulação da qualidade dos cursos.

Além disso, os embates ocorridos no contexto da aprovação das DCN da licenciatura em pedagogia sugeriram a possibilidade de que sua apropriação no Parfor e no Sinaes terem seguido caminhos distintos. Discussões que ilustram essa perspectiva de entendimento foram encontradas em Libâneo (2006), Franco, Libâneo e Pimenta (2007) e Pimenta, Franco e Libâneo (2010) as quais apontaram que as DCN em foco estabeleceram limites pouco claros entre o enriquecimento e a dispersão da formação do professor, a partir da incorporação dos conteúdos a serem ensinados e suas didáticas com aqueles afetos à gestão escolar, não escolar e de sistemas educativos.

Conforme esclareceram Aguiar et al. (2006, p. 830) "[a docência, nas diretrizes da licenciatura em pedagogia] não é entendida no sentido restrito do ato de ministrar aulas. $\mathrm{O}$ sentido da docência é ampliado, uma vez que se articula à ideia de trabalho pedagógico, a ser desenvolvido em espaços escolares e não-escolares". Essa ponderação corroborou o entendimento de que um curso de pedagogia adequado, conforme discutido no âmbito da aprovação das DCN do curso, não deve estar circunscrito ao campo das metodologias de ensino e dos conteúdos relativos aos saberes específicos para o exercício da docência na educação infantil e nos anos iniciais do ensino fundamental. Durante o processo de elaboração do que mais tarde se tornariam essas diretrizes, Scheibe e Aguiar (1999) foram específicas ao afirmar que a proposta do documento legal assumiu a tese de que o curso visa à formação de profissional habilitado para atuar no ensino, na organização e na gestão de sistemas, unidades e projetos educacionais e na produção e difusão do conhecimento, em diversas áreas da educação, tendo como base a docência.

No entanto, decorridos quatro anos da aprovação do documento legal, Gatti (2010) apontou fragilidades nos currículos dos cursos destinados à preparação de docentes, em geral, mas que também se aplicam à licenciatura em pedagogia em particular, a saber:

a) o currículo proposto pelos cursos de formação de professores tem uma característica fragmentária, apresentando um conjunto disciplinar bastante disperso;

b) a análise das ementas revelou que, mesmo entre as disciplinas de formação específica, predominam as abordagens de caráter mais descritivo e que se preocupam menos em relacionar adequadamente as teorias com as práticas;

c) as disciplinas referentes à formação profissional específica apresentam ementas que registram preocupação com as justificativas sobre o porquê ensinar; entretanto, só de forma muito incipiente registram o que e como ensinar; 
d) a proporção de horas dedicadas às disciplinas referentes à formação profissional específica fica em torno de $30 \%$, ficando $70 \%$ para outro tipo de matérias oferecidas nas instituições formadoras; cabe a ressalva já feita na análise das ementas, segundo a qual, nas disciplinas de formação profissional, predominam os referenciais teóricos, seja de natureza sociológica, psicológica ou outros, com associação em poucos casos às práticas educacionais;

e) os conteúdos das disciplinas a serem ensinadas na educação básica (Alfabetização, Língua Portuguesa, Matemática, História, Geografia, Ciências, Educação Física) comparecem apenas esporadicamente nos cursos de formação e, na grande maioria dos cursos analisados, eles são abordados de forma genérica ou superficial, sugerindo frágil associação com as práticas docentes;

f) poucos cursos propõem disciplinas que permitam algum aprofundamento em relação à educação infantil (GATTI, 2010, p. 1371).

A autora constatou também que o número de disciplinas teóricas da área de educação (tais como didática) é reduzido e que há um desequilíbrio entre os eixos teórico e prático nas disciplinas de formação específica para a docência. Para ela, "as ementas registram preocupação com teorias de ensino e com justificativas sobre por que ensinar, mas só de forma muito incipiente registram o quê e como ensinar" (GATTI, 2009, p. 22).

Tais achados provocaram dúvidas de duas ordens principais sobre a apropriação do documento legal em foco pelo Parfor e pelo Sinaes: primeira, se os cursos presenciais de pedagogia chancelados pelo Parfor também apresentaram a frágil perspectiva de formação do docente apontada por Gatti (2009, 2010); segunda, se os critérios de qualidade utilizados pelo Sinaes para avaliar os cursos de licenciatura no Brasil, entre eles o de pedagogia, são capazes de captar os dados que demonstraram a frágil formação teórica e prática que os licenciandos vêm recebendo nas disciplinas com conteúdo específico para a regência de classe, de forma a subsidiar a sua regulação em torno da base docente, previstas nas DCN do curso.

Adicionalmente, o Sinaes vem considerando a avaliação de cursos de graduação de forma padronizada, sem especificação entre as áreas de conhecimento. Essa perspectiva isomórfica assumida pelo Sinaes permitiu considerar que aspectos particulares na definição de qualidade das licenciaturas - como o próprio conceito de docência ou o entendimento sobre a profissionalidade ${ }^{21}$ do egresso - podem não estar sendo adequadamente tratados pelo Sinaes, sugerindo a possibilidade de arranjos diferenciados entre o que plano de formação de professores e o sistema avaliativo assumem como qualidade no curso de pedagogia.

\footnotetext{
${ }^{21}$ O conceito de profissionalidade foi definido por Gatti (2010, p. 1360) como o "conjunto de características de uma profissão que enfeixam a racionalização dos conhecimentos e habilidades necessárias ao exercício profissional". Neste trabalho, o conceito em destaque foi apropriado de forma a especificar o conjunto de conhecimentos e habilidades capaz de individualizar o exercício de uma profissão, destacando-a das demais correlatas. Estaria, pois, na profissionalidade, o que, por exemplo, faz um auxiliar de enfermagem não exercer os mesmos encargos de um enfermeiro, assim como um neurologista em relação a um cardiologista, ou um professor de química em relação a um pedagogo.
} 
Assim, a despeito de formalizações, o delineamento legal e empírico observado, permitiu visualizar a Política de Qualidade por meio da relação entre aquilo que o Parfor e o Sinaes assumiram individualmente como um bom curso de pedagogia. A partir dessa relação, assumiu-se a existência de um padrão de qualidade para cursos de formação de professores da educação infantil e dos anos iniciais do ensino fundamental, que difunde orientações do governo brasileiro em torno da qualidade da formação em foco. Com base nesse entendimento, buscou-se adentrar nessa discussão, inserindo tal entendimento sobre a Política de Qualidade no campo teórico das políticas públicas, bem como no desdobramento empírico viabilizado por ela, conforme discussões presentes nas seções 1.3 e 1.4 .

\subsection{CONSTRUÇÃO TEÓRICA PARA UMA REALIDADE DE FATO}

A busca de subsídios teóricos para justificar os pontos de articulação ente o Parfor, Sinaes e as DCN da licenciatura em pedagogia como política pública específica permitiu encontrar em Souza (2006, p. 26) o esclarecimento que "definições de políticas públicas, mesmo as minimalistas, guiam o nosso olhar para o lócus onde os embates em torno de interesses, preferências e ideias se desenvolvem, isto é, os governos". Ainda segundo a autora, a expressão política pública é polissêmica, podendo estar associada a um campo dentro do estudo sobre o governo à luz de grandes questões públicas, ao entendimento de que se constitui em um conjunto de ações governamentais que impactam a vida dos cidadãos, e à concepção de que se trata das ações, mas também das não ações dos governos.

No âmbito da revisão realizada por Souza (2006) depreendeu-se que a participação estatal, seja ela direta, indireta, ativa ou passiva, ${ }^{22}$ mostrou-se como elemento-chave para identificar uma política pública, bem como os interesses que se organizam, se contrapõem ou colaboram em torno dela. Também, destacou-se o fato de não serem reportadas vinculações estritas de políticas públicas a documentos legais e ou vinculações orçamentárias, mas, sim, à sua repercussão efetiva na vida social.

Corroborando essa compreensão, encontrou-se em Jobert e Muller (1987) a perspectiva de que as políticas públicas se definem sob a égide de um programa de ação governamental. Posteriormente, Muller (2002) reforçou que esse programa governamental que definem uma política pública pode envolver tanto objetivos declarados quanto objetivos

\footnotetext{
${ }^{22}$ Assumiu-se a participação do governo de forma direta, quando ele executa diretamente as ações que envolvem a política. Indireta, quando tais ações são delegadas a organizações não estatais. Já a participação ativa ou passiva do governo foi compreendida a partir da ideia de que a máquina pública pode envolver-se ativamente no processo de formulação, estruturação, execução, avaliação e revisão de uma política pública, ou simplesmente não agir, sem, no entanto, deixar de gerar consequências relevantes para a sociedade.
} 
ocultos ou subjacentes. Como seguiu explicando, uma ação pública pode consistir em não fazer nada ou, ainda, apenas regular, sem gerar impacto financeiro no orçamento público.

Para Muller e Surel (2002), nem sempre a identificação ou o delineamento de uma política pública segue caminhos fáceis. Esses autores assumiram que ela reflete um sentido implícito ou explícito da ação do Estado, bem como a expressão, ou não, de uma decisão governamental. De acordo com essas referências, a despeito de formalizações, uma política pública se expressa a partir de medidas concretas (constituindo o quadro da ação/não ação do governo), as quais alteram a vida dos atores sociais (expressando o poder estatal) e regulam as relações entre esses atores (constituindo uma ordem local).

Adicionalmente, encontrou-se em Frey (2000) o entendimento que conceito de política pública pode ser associado a três dimensões: i) à ordem estabelecida pelas instituições que regulam a política; ii) aos processos políticos que, balizados pelo quadro institucional, se expressam por embates e disputas em torno das decisões do governo; e iii) aos conteúdos das decisões políticas que configuram materialmente a política pública. Essas dimensões foram deduzidas pelo autor com base nas diferenciações existentes na língua inglesa para o que em português possui uma única expressão: política pública. No entanto, o próprio Frey (2000) alertou que não caberia a separação entre elas, sob pena de que tal redução distanciasse o conceito da realidade que representa.

Tendo como referência essas considerações e o comportamento empírico do objeto desta pesquisa, entendeu-se, em síntese, que uma política pública não se restringe apenas aos conteúdos das decisões do Estado que provocam arranjos de ação/não-ação governamental, mas envolve, complementarmente, os processos políticos que determinaram tais decisões, bem como o quadro institucional legal-político-administrativo no qual elas estão inseridas. Dessa forma, assumindo-se que políticas públicas são delineadas por meio de disputas diversas que afetam a vida de pessoas, organizações, setores e campos de atuação humana, buscou-se no desenvolvimento desta pesquisa dialogar com o conhecimento construído em torno do tema. Nesse processo, as discussões teóricas visitadas destacaram uma relação dialética entre Estado e sociedade civil, remetendo a interesses que podem ser polarizados, mas também complementares e, até mesmo, ambíguos, recíprocos ou de implicação múltipla.

Aprofundando-se na discussão sobre as relações dialéticas entre sociedade e Estado, encontrou-se em Gramsci (1982) o entendimento de que a sociedade civil é distinta do Estado, mas termina por organizar as relações humanas de forma eminentemente política. Por isso, segundo o autor, a sociedade civil exerce importante influência nas decisões de governo na busca de garantir a hegemonia da classe dominante, por meio do consentimento espontâneo 
das classes dominadas. Para Gramsci (1982), a sociedade política - mais prontamente associada ao conceito de Estado - corresponde à dominação imposta pelo aparato de leis, quando o consentimento espontâneo, capitaneado pela sociedade civil, deixa de funcionar.

Em sua perspectiva de análise sobre a relação entre Estado e sociedade civil, Gramsci (1982) reforçou a ideia de que o Estado é um instrumento que representa interesses particulares, constituindo-se em uma entidade subjacente à sociedade, ao mesmo tempo que é condicionado por ela. Além disso, sugeriu que o Estado usa a cultura popular, a mídia, a educação e a religião para reforçar uma ideologia que apoia as classes dominantes, por meio de um processo sutil de imposição de hegemonia. Há que se ressaltar ainda que é na sociedade civil que Gramsci (1982) estabeleceu o espaço onde ocorre a disputa ideológica hegemônica, na qual os detentores do capital terminam por garantir os seus interesses. Para o autor, a sociedade civil difunde conteúdos e valores capitalistas (ideologia dominante) enquanto protege, e é protegida pelos mecanismos de coerção da sociedade política (hegemonia).

Apesar desse entendimento, é necessário pontuar que Gramsci (1982) não assumiu uma postura determinística sobre a relação Estado-sociedade civil em prol da ideologia da classe dominante. Mesmo destacando que a ideologia hegemônica garante a direção moral e política dos capitalistas, o autor colocou em relevo a importante função que os intelectuais exercem no processo da reprodução social. Para Gramsci (1966), todos os homens podem exercer o papel de intelectual (não só aqueles academicamente preparados), dentro dos seus limites de atuação e pensamento filosófico contido na religião, na linguagem, no senso comum (comportamento passivo, seguindo valores e normas correntes da sociedade capitalista) e no bom senso (questionamento do senso comum, visando transformar a realidade numa perspectiva menos competitiva e desigual). Nesse sentido, mesmo que a ideologia dominante, ou hegemônica, penetre o senso comum com seus valores, há sempre o componente do bom senso crítico, o qual pode ser exercido filosoficamente pelos homens (tomados como intelectuais orgânicos), de forma a fazê-los encontrar o caminho da contrahegemonia.

Considerando a perspectiva de Estado e do papel dos intelectuais trazidos por Gramsci (1966, 1982), quando se analisou o Estado brasileiro e, dentro dele, a Política de Qualidade, foi possível considerar que as ações estatais terminaram por refletir os pressupostos, valores e concepções que emanam da sociedade civil. Nesse processo, como formuladores de ideias e 
ideais, os intelectuais pareceram exercer um papel fundamental tanto na estruturação das políticas públicas quanto no seu questionamento. ${ }^{23}$

Apesar disso, há que se relembrar que o método escolhido para a busca de resposta à pergunta de pesquisa aqui definida foi o hiperempirismo dialético, enquanto Gramsci (1982) utilizou como base para sua análise o materialismo histórico dialético. Assim, embora seja possível considerar a concepção de Estado trazida pelo autor, bem como suas observações sobre o papel que os intelectuais podem exercer na relação Estado-sociedade, identificaram-se limites no seu poder explicativo das relações estudadas nesta pesquisa. No caso da Política de Qualidade, reconheceu-se a possibilidade de haver um vácuo entre a base epistemológica da teoria gramsciana - que possui uma perspectiva de ação para a transformação do capitalismo em socialismo - e aquela utilizada nesta pesquisa, que não escolhe caminhos previamente. A dialética de Gurvitch (1987) questiona o socialismo como apogeu da organização social, numa perspectiva de que não se deve limitar a priori a criatividade humana para encontrar soluções para resolver seus conflitos e problemas.

Nesse sentido, os procedimentos operacionais do hiperempirismo dialético associados à realidade da Política de Qualidade tenderam a redimensionar a possibilidade da participação de qualquer cidadão como um intelectual em potencial, capaz de influenciar as ações de governos. $\mathrm{O}$ espaço de influência dos intelectuais na política brasileira de qualidade para a formação de professores pareceu restringir-se aos especialistas em determinada área de conhecimento, no seu trabalho de reflexão e proposição de soluções, as quais têm sido incorporadas pela ação estatal na tentativa, ou não, de ampliar concessões da classe dominante aos menos favorecidos.

Adicionalmente, sem descartar a influência que as elites econômicas exercem nas ações, omissões e decisões estatais, para que estas reproduzam seus interesses - também pontuada por Marques (1997) - a visão polarizada entre burguesia e proletariado presente em Gramsci $(1966,1982)$ não foi suficiente para discutir os movimentos identificados na Política de Qualidade. A realidade analisada conduziu ao entendimento de que poderiam ocorrer aglutinações de pessoas em grupos, os quais compartilhariam objetivos, valores éticos, morais e políticos e que, por sua vez, influenciam as ações do Estado. Porém, a simples agregação desses grupos em classes sociais dicotômicas não ofereceu os subsídios necessários à análise do problema de pesquisa.

${ }^{23}$ Exemplos do papel exercido pelos intelectuais em torno da Política de Qualidade foram analisados nas subseções 1.4 .2 e 1.4.3 deste capítulo. 
Nesse sentido, encontrou-se em Lowi $(1964,1972)$ um arcabouço teórico que propôs a existência de grupos de interesse durante o processo de definição e implantação das políticas públicas. Segundo o autor, as ações do governo sempre envolvem algum tipo de coerção remota $^{24}$ ou imediata ${ }^{25}$ - que pode ser aplicada tanto em nível de sistema, desencadeando os interesses de segmentos sociais específicos, quanto em nível de conduta individual, afetando diretamente o interesse de pessoas, sejam elas físicas ou jurídicas.

Da possibilidade de cruzamento entre os tipos de coerção (remota ou imediata) e os níveis de aplicação (sistema ou conduta individual), Lowi (1972) identificou quatro tipos de políticas públicas, a saber: a) políticas distributivas, que implicam decisão de aplicação de recursos financeiros privilegiando determinados grupos, setores ou regiões; b) políticas regulatórias, que estabelecem regras, procedimentos ou formas de atuação, envolvendo políticos e grupos de interesse; c) políticas redistributivas, que preveem o atendimento a grupos sociais menos privilegiados, impondo perdas concretas a alguns (que são obrigados a contribuir para a ação, geralmente por meio de impostos), e ganhos incertos a outros (que podem se beneficiar da política); e d) políticas constitutivas, como aquelas voltadas à consolidação do próprio governo por meio de relatório, prestação de contas ou propaganda.

Com base nesse referencial, a Política de Qualidade aqui estudada pôde ser enquadrada como regulatória, na medida em que organizou e orientou a oferta dos cursos de formação inicial de docentes para a educação infantil e primeiros anos do ensino fundamental de forma descentralizada. Além disso, permitiu destacar grupos de interesses ao exercer uma linha de coerção imediata em relação a: i) alunos interessados em cursos que lhes ofereçam maior prestígio e qualidade de formação, no âmbito do Sinaes; ii) instituições formadoras em busca de reconhecimento social e sustentabilidade dos cursos oferecidos; iii) associações profissionais e acadêmicas desejosas por manter sua capacidade de influência sobre na definição daquilo que se considera qualidade no âmbito do Parfor quanto do Sinaes; iv) professores das redes estaduais e municipais de educação básica, beneficiados diretamente pelo Parfor; e v) instituições e grupos políticos baseados nas secretarias estaduais e municipais de educação, beneficiados indiretamente pela melhoria de indicadores de qualificação docente que tendem a impactar positivamente a percepção da população de eleitores sobre a qualidade da educação básica.

\footnotetext{
${ }^{24}$ A coerção remota ocorre quando inexistem sansões ou elas são indiretas, como é o caso da concessão de um subsídio, cujos ônus são diluídos entre todos os pagadores de impostos.

${ }^{25}$ A coerção imediata afeta diretamente grupos de interesse, uma vez que para beneficiar uns, outros oferecem contrapartida direta, como no caso do pagamento de auxílios da seguridade social, que impõe contribuições aos mais ricos para favorecer os não abastados.
} 
As ideias de Lowi $(1964,1972)$ permitiram assumir a predominância de interesses relacionados a grupos e a políticos no desenvolvimento da Política de Qualidade, tornando mais operacional a análise de políticas públicas como constructo de pesquisa. Porém, entendeu-se que a proposta do autor em destaque não foi capaz de superar as proposições gramscianas no que se referiu às relações Estado-sociedade civil anteriormente discutida. Com isso, pôde-se identificar uma relação de implicação dialética mútua ${ }^{26}$ entre elas, cujo ponto de contato se materializou na perspectiva de influência exercida pela sociedade civil sobre o Estado durante o processo de definição e implantação das políticas públicas: ambos os autores apontaram para a existência de permeabilidade dos interesses da sociedade nas ações do Estado. Já o ponto de afastamento foi encontrado nas condições de poder para se ter acesso a essa influência. Gramsci $(1966,1982)$ defendeu que não são todos os interesses que permeiam essa ação, mas notadamente aqueles vinculados à classe que detém a hegemonia social: os burgueses. Já Lowi $(1964,1972)$ absteve-se de discutir a ideia de hegemonia dos interesses de um grupo ante os demais, bem como o papel da burocracia estatal nesse contexto.

No entanto, nem nas ideias de Gramsci $(1966,1982)$ nem nas de Lowi $(1964,1972)$ foram encontrados todos os elementos necessários à análise dos interesses da burocracia estatal envolvida nas questões relativas à Política de Qualidade. Os interesses das instituições responsáveis pela condução do Parfor e do Sinaes, aliados ao seu poder decisório, não permitiram considerá-las como totalmente passivas, frente aos interesses da sociedade civil, nem detentoras do mesmo status que os demais grupos de interesse ou dos políticos em suas ambições corporativas e eleitorais. Conforme alertou Rocha (2005, p. 14), [...]

\begin{abstract}
[...] as ações do Estado, implementadas por seus funcionários, obedecem à lógica de buscar reproduzir o controle de suas instituições sobre a sociedade, reforçando sua autoridade, seu poder político e sua capacidade de ação e controle sobre o ambiente que o circunda. A burocracia estatal, especialmente a de carreira, estabelece políticas de longo prazo diversas das demandadas pelos atores sociais. Suas ações buscam propor visões abrangentes sobre os problemas com que se defrontam. A capacidade que a burocracia tem de elaborar e implementar políticas é, em parte, resultante do controle que ela exerce sobre um recurso de poder privilegiado, que é o acesso diferenciado à informação. Nessa perspectiva, as decisões públicas trazem, portanto, a marca dos interesses e das percepções que a burocracia tem da realidade.
\end{abstract}

Nesse sentido, entendeu-se que, além dos indivíduos organizados em grupos de interesse e dos políticos, houve ainda o importante papel das instituições burocráticas nas

${ }^{26}$ Conforme definido por Gurvitch (1987), a implicação dialética múltipla procura pontos de afinidades na relação entre contrários. 
ações em torno da Política de Qualidade. Tal importância emergiu dos interesses da própria burocracia estatal envolvida no estabelecimento das regras do Sinaes e na redistribuição de recursos promovidos pelo Parfor, que não se confundiram, necessariamente, com os interesses dos demais grupos.

O predomínio da burocracia estatal na condução de políticas públicas foi discutido por Scokpol (2002), que propôs a centralidade dos funcionários públicos na proposição e desenvolvimento das políticas públicas, viabilizada por certo insulamento de seus interesses frente aos demais interesses de grupos ou na sociedade civil. Essa autora afirmou que a autonomia das ações das agências estatais seria autorreferenciada na sua sobrevivência e exercício de poder, vinculando-se prioritariamente aos seus próprios interesses, sem a perspectiva explícita de submissão aos interesses da sociedade. Com isso, essa autora polarizou em torno dos princípios presentes nas discussões trazidas por Gramsci $(1966,1982)$ e Lowi $(1964,1972)$ de haver certa simbiose do Estado em ação aos interesses da sociedade civil.

Todavia, tal posição, longe de minimizar a importância dos grupos de interesse na formulação e desenvolvimento de políticas públicas, pareceu ter destacado o papel desempenhado pelas burocracias na condução desse processo, deixando de vê-las como passivas e submissas, para visualizá-las como ativas e dotadas de interesses próprios. Nesse sentido, a questão dos interesses das instituições estatais na condução de uma política pública poderia ser tomada como complementar às ideias de Lowi $(1964,1972)$ na medida em que pode ser entendida pela ascensão dos funcionários públicos como mais um grupo de interesse que, embora não sintetize o Estado, é o responsável, em última instância, por suas ações. Já em relação à perspectiva gramsciana em torno da proeminência dos interesses dos detentores dos meios de produção na ação do Estado, não foi possível contemplá-la na perspectiva de relativa independência da burocracia estatal, mantendo-se, portanto, uma relação de polarização entre a visão que coloca a burocracia como central na influência sobre a ação estatal e aquela que reserva esse papel aos burgueses detentores do capital.

Por outro lado, conforme lembrou Faria (2003), apesar da capacidade de interferência de políticos, burocratas e demais grupos de interesse na formulação e no desenvolvimento das políticas públicas, o atual estágio de desenvolvimento do capitalismo tem difundindo a perspectiva de que esses processos envolvem uma multiplicidade de atores, tendo em vista a complexidade das novas relações que se estabelecem em um mundo globalizado. Segundo o autor, recentemente tem emergido a perspectiva de que é preciso examinar o conhecimento como uma categoria que não pode ser considerada como simples insumo ao jogo de interesse 
ou como justificativa para a influência das ideias nas ações do Estado. Para ele, o conhecimento - entendido como a instrumentalização de dados, argumentos e ideias que influenciam a formação da agenda e o leque de soluções que configuram as ações governamentais - emergiu como um importante aspecto para a análise das políticas públicas, sendo necessário utilizar o poder inerente à sua ocorrência como complementar à análise da interação entre os grupos de interesse. Dessa forma, considerando o contexto da Política de Qualidade, buscou-se completar a análise das relações dialéticas envolvidas nessa ação do governo, notadamente no que se referiu a perspectivas teóricas que estruturam a sua implantação, abordando a questão do conhecimento, também aludida tangencialmente por Gramsci (1982) em sua discussão sobre a influência dos intelectuais nas ações do Estado.

Para discutir essa influência, encontrou-se em Haas (1992) o raciocínio de que quando os desafios do macroambiente econômico-social, e também ecológico, estão atrelados à necessidade de ação dos governos, os que apresentam soluções embasadas em conhecimentos científico e tecnológico participam igualmente do jogo de influência sobre a ação estatal. Dentro desta perspectiva, Haas (1992) sugeriu que os especialistas organizados em redes de conhecimento, ao articularem respostas para os diversos problemas, se apresentam como fonte de influência para a formulação e implementação de políticas públicas. O autor argumentou, ainda, que o controle sobre o conhecimento e a informação é uma importante dimensão do poder, permitindo a difusão de novas ideias e influenciando o comportamento de novos parceiros, constituindo-se como elemento-chave para explicar a influência de redes de especialistas sobre as ações de governo. Tais redes, também chamadas por Haas (1992) de comunidades epistêmicas, não contam com requisitos formais para existir, sendo reconhecidas pela expertise profissional de um grupo que partilha dados, ideias, valores comuns e iniciativas em determinada área de conhecimento.

A partir dessa ideia foi possível notar a organização de especialistas em associações e de grupos de pesquisa, não só nacionalmente, mas também internacionalmente. No caso da formulação de políticas educacionais, observou-se que, pelo menos, uma rede internacional foi especialmente criada para marcar a influência sobre as ações dos governos. É o caso da Comissão Internacional sobre Educação para o Século XXI, surgida a partir de encaminhamento da Conferência Geral da Unesco de 1991, em Jomtien (Tailândia), para atender ao objetivo de [...]

[...] efetuar um trabalho de estudo e reflexão sobre os desafios a enfrentar pela educação nos próximos anos e apresentar sugestões e recomendações em forma de relatório, que poderá servir de programa de renovação e ação para quem tiver de 
tomar decisões, e para os responsáveis oficiais no mais alto nível. [...] propor perspectivas, tanto políticas como relacionadas com a prática da educação, que sejam ao mesmo tempo inovadoras e realistas, tendo em vista a grande diversidade de situações, de necessidades, de meios e de aspirações, segundo os países e as regiões. Destinar-se-á, principalmente, aos governos, mas sendo um dos seus objetos tratar do papel da cooperação e da ajuda internacional em geral e, mais em particular, do papel que cabe à UNESCO, a Comissão deverá também esforçar-se por formular, nesse relatório, recomendações úteis aos organismos internacionais (DELORS, 1997, p. 272).

Nesse sentido, pode-se inferir que o relatório da Comissão Internacional foi encomendado pela Unesco para instrumentalizar as decisões de governos e de organismos internacionais. Para tanto, os membros da Comissão foram escolhidos de forma a contemplar pessoas com acesso ao poder governamental nos seus países de origem e com influência internacional, tais como Jacques Delors, que presidiu a Comissão Internacional, tendo sido presidente da Comissão Europeia, ${ }^{27}$ e Roberto Carneiro, ex-ministro da Educação de Portugal, entre outros.

Considerando, pois, as características dos membros da Comissão Internacional e dos diversos colaboradores que com ela contribuíram, supôs-se que a influência dos responsáveis pela elaboração do Relatório, ao lado da própria Unesco, ${ }^{28}$ configurou-se como chave para a difusão do conteúdo prescrito pelo relatório. Além disso, a predisposição de que o documento inspirasse outros organismos internacionais pareceu estruturar uma rede de influência para que as ideias nele presentes auxiliassem, por exemplo, o Banco Mundial, por meio do Banco Internacional para Reconstrução e Desenvolvimento (Bird), na exigência de contrapartidas relativas à área de educação quando do financiamento de ações de governos nacionais. ${ }^{29}$

Outras redes internacionais de especialistas também emergiram em torno de preocupações com a formação docente, como a Rede Docente da América Latina e do Caribe (Kipus) e a Rede Latinoamericana de Estudos sobre o Trabalho Docente (Estrado), entre

27 A Comissão Europeia é uma das instituições da União Europeia, responsável por preparar projetos de lei do bloco e por assegurar a execução das políticas e dos seus recursos financeiros.

28 Vale salientar que embora a Unesco tenha patrocinado a elaboração do Relatório, assumiu que o produto final não é seu, mas sim da Comissão Internacional. Essa Comissão, conforme seu relato, trabalhou de forma independente do organismo internacional, embora tenha se inspirado na história e nas ações da Unesco para a formulação das propostas contidas no "Relatório Educação um Tesouro a Descobrir” (DELORS, 1997).

${ }^{29}$ Considera-se que os principais conteúdos do Relatório Delors pertinentes à Política de Qualidade podem ser sintetizados como: orientação de que todos os professores da educação básica tenham formação superior; que os professores participem mais das decisões relacionadas à educação para que se sintam comprometidos e colaborativos com elas; e que se criem sistemas de avaliação e de controle em prol do ensino de qualidade. 
outras. ${ }^{30}$ Com base em informações disponibilizadas no sítio internet de cada uma delas, pode-se assumir que a Kipus, ligada à Unesco, foi criada em 2003 de forma alinhada a princípios e valores educacionais voltados aos ganhos de competitividade e produtividade dos países. Fomenta a troca de experiências entre instituições e docentes formadores dos futuros professores da educação básica, visando ao "desenvolvimento e protagonismo docente como chave para as transformações educativas”. Já a Estrado foi criada em 1999, no âmbito do Conselho Latinoamericano de Ciências Sociais (Clacso), para a consolidação do campo de estudos sobre o trabalho docente. É formada por pesquisadores que têm uma abordagem crítica à ideia da centralidade do docente como o responsável principal pela transformação da educação, discutindo os limites dessa centralidade, impostos pelos contextos institucional (salários, qualificação, incentivos e demais condições de trabalho) e escolar (estrutura física, participação familiar e dos alunos, violência, entre outros).

Assim, embora ambas as redes defendam a qualidade da educação, parecem divergir quanto aos meios para a busca desse objetivo. Para a rede Estrado, os valores de emancipação do sujeito e protagonismo social parecem centrais. Para a rede Kipus, a visão de educação como pilar para o desenvolvimento econômico e o alcance da vantagem competitiva do mercado globalizado aparentemente se mostraram mais relevantes. Essa dualidade levou inevitavelmente ao questionamento sobre se o que elas vêm buscando em termos de uma educação de qualidade é contraditório ou se faz parte de uma complementaridade dialética. ${ }^{31}$

A literatura polarizada do campo não ofereceu resposta fácil nem conclusiva sobre a pertinência e relevância de cada uma dessas perspectivas. Em termos de exercício da reflexão, no entanto, admitiu-se que a busca pelo aumento dos níveis de escolaridade com qualidade pela população pode garantir, ao mesmo tempo, emancipação do trabalhador e lucro para o capital, independentemente do conteúdo crítico ou não trabalhado em sala de aula. A educação de qualidade costuma ser apontada como um fator importante no desenvolvimento da capacidade do indivíduo pensar, ter novas ideias e promover o diferencial competitivo das empresas para aumentar o lucro do capital. Porém, não há instrumentos disponíveis que possam limitar tal capacidade exclusivamente à geração de benefícios econômicos

\footnotetext{
${ }^{30}$ Como exemplo de outra rede de especialistas na área de formação de professores, tem-se a RIED - Rede Interamericana de Educação Docente, ligada à Organização dos Estados Americanos que, diferentemente da Rede Kipus e da Rede Estrado, agrega o próprio professor da educação básica como membro. Em termos de concepção, suas ideias aproximam-se da Rede Kipus, inclusive na utilização de documentos produzidos pela Unesco para justificar a criação da rede. Para fins dos objetivos buscados nessa discussão, optou-se por analisar apenas duas redes que parecem representar cada uma um polo das discussões sobre a questão da formação de professores.

${ }^{31}$ Na perspectiva de Gurvitch (1987), significa considerar que a contrariedade entre elementos pode ser apenas aparente.
} 
direcionados à burguesia. Assumindo-se que o trabalhador é um ser livre, não se pode descartar a possibilidade de que este utilize a força do seu próprio raciocínio e criatividade para o exercício pleno de sua liberdade e bem-estar, segundo alertou Gramsci (1982) com a discussão acerca dos intelectuais orgânicos.

Nesse sentido, Sobral (2000) sinalizou que as dimensões social e econômica da educação não seriam necessariamente excludentes. Assumindo, pois, essa assertiva, não haveria, em tese, contradição, mas, sim, complementaridade entre os possíveis resultados advindos de uma educação com qualidade, seja para o trabalhador, seja para o sistema capitalista no qual está inserido. Tal entendimento poderia abrir novas perspectivas de análise e proposições do que caracterizaria a educação de qualidade dentro do processo formativo, em geral, e de professores, em particular.

Sobre divergências entre especialistas que formam a comunidade epistêmica, Haas (1992) sugeriu a existência de várias comunidades epistêmicas dentro de um mesmo campo do saber. Considerando, então, a possibilidade de uma alternativa de solução para o mesmo problema que demanda uma política pública, pareceu prudente questionar o que faz, então, uma determinada rede de profissionais e não outra influenciar a ação dos governos. Por que determinadas soluções se materializam como políticas públicas e outras não?

Uma possível resposta a esse questionamento pode estar localizada nos resultados da pesquisa de Marques (1999), que analisou as relações estabelecidas entre Estado e sociedade no processo de formulação e gestão de política pública urbana de saneamento básico no Rio de Janeiro e identificou uma rede que permeava a ação estatal. Tal rede se formou pela cristalização das relações entre indivíduos, grupos e organizações no exercício de suas atividades diárias, passando a atuar como estruturas que influenciam o desdobramento de processos políticos e a sua própria transformação. Segundo relato do autor, a rede da comunidade profissional se estabeleceu a partir de indivíduos que assumiram posições no campo em que o órgão estatal se encontrava inserido. Com isso, as posições dos atores nessas redes passaram a moldar suas ações e estratégias, ajudando a construir preferências, projetos, visões de mundo e dando acesso aos seus membros a recursos de poder como status e prestígio, além de outros mais facilmente mensuráveis, como dinheiro e informação.

A partir dos achados de Marques (1999), inferiu-se que as posições ocupadas por integrantes da rede de especialistas no governo justificariam a adoção de um direcionamento intelectual em detrimento de outro, assim como a discussão crítica, ou não, da decisão tomada. $\mathrm{O}$ autor denominou essa relação encontrada entre a rede da comunidade profissional e o Estado de "permeabilidade", conforme afirmou: 


\begin{abstract}
A permeabilidade é produzida a partir de uma teia de relações e cumplicidades construída ao longo da vida dos indivíduos, incorporando diferentes tipos de elos que se espalham por todas as dimensões do social. Relações pessoais e de amizade construídas no decorrer de anos, algumas familiares, outras oriundas da formação profissional, e outras ainda constituídas por vínculos de trabalho e afinidade política, constituem essa rede que abrange e integra diversos campos da vida social, tanto dentro quanto fora do Estado. Esse padrão não é baseado em um pequeno número de relações de caráter intencional, localizadas em setores específicos, que ligariam verticalmente os setores público e privado (e horizontalmente entre eles), mas, ao contrário, em incontáveis relações pulverizadas (MARQUES, 1999, p.49).
\end{abstract}

Nesse sentido, a permeabilidade pôde ser entendida como uma consequência da rede de relações estabelecidas na comunidade profissional, uma vez que essa comunidade estaria associada duplamente ao órgão provedor da ação política e às demais organizações que orbitam em torno dele e podem constituir, ou não, o objeto dessa ação. Caracterizou-se por ser um processo que ocorre de forma dispersa, canalizado por relações estabelecidas sem o propósito deliberado de maximização de interesses específicos, ou, até mesmo, com outras intenções, podendo, inclusive, não possuir finalidade alguma (MARQUES, 1999). Em síntese, permeabilidade foi definida como as ações do governo, baseadas em conhecimentos defendidos por redes de especialistas, as quais são estruturadas a partir de relações pessoais entre os agentes públicos e privados que têm interesse no tema da ação.

Assim, as discussões sobre as relações entre Estado, sociedade e políticas públicas ressaltaram os interesses de grupos na ação dos governos, incluindo os dos especialistas que contribuem para a formulação e implantação dessas ações. Adicionalmente, a tentativa de analisar os fenômenos numa perspectiva de sua totalidade sistêmica permitiu destacar que o fenômeno e o contexto modificam-se mutuamente. Com isso, foi possível considerar a probabilidade de a Política de Qualidade, como fenômeno formado a partir da interação de elementos menores - Parfor, Sinaes e DCN - estar inserida na relação Estado e sociedade, como contexto. No âmbito dessas relações, entendeu-se que interesses comuns poderiam associar pessoas em grupos, e que estes estariam embasados em posturas e visões de mundo não necessariamente iguais. Nesse sentido, essas possíveis divergências ofereceriam a oportunidade de relacionar esses grupos de forma ambígua, ao permitirem gerar tanto o conflito quanto o enriquecimento coletivo pela diversidade de ideias.

Há que se ressaltar, no entanto, que a visualização, neste estudo, da Política de Qualidade como um sistema não pressupôs que ela estivesse organizada de forma linear e ajustada. De acordo com Muller e Surel (2002), os limites que definem uma política pública podem ser sempre questionados por um processo constante de redefinição de sua estrutura. 
Para eles, é sempre mais proveitoso analisar o Estado em ação por meio dos seus mecanismos de construção, para que as análises possam "sobrevalorizar a racionalidade da própria ação, ou, ao contrário, colocar em causa a coerência, até a existência, da ação governamental" (p.13). Por isso, aos se considerar a totalidade das relações entre os elementos que compõem à política, não implicou necessariamente considerá-la como um sistema coerente e ajustado.

Tornou-se necessário reiterar, ainda, que esse entendimento da Política de Qualidade como um sistema foi construído a partir do método hiperempirista dialético - que na leitura de Cánovas (1997) promove a integração de elementos que são, em si mesmos, sistemas ou totalidades - e pela perspectiva gramsciana de que a sociedade civil interage permanentemente com a sociedade política (Estado), difundindo conteúdos e valores que repercutem nas ações estatais ou políticas públicas. Porém, reconheceu-se que essa formulação ampliada de Estado trazida por Gramsci (1982), articulando a sociedade política e a sociedade civil, pareceu trazer consigo a ideia de que por meio do bom senso - promovido pela participação ativa dos proletários e intelectuais orgânicos - seria possível transformar o conteúdo ideológico do Estado em prol da sociedade sem classes e sem a exploração burguesa.

Todavia, Gurvitch (1987, p.10) foi enfático na sua proposição de que "a causa da dialética está perdida de antemão, se começa por aliar-se a uma tomada de posição filosófica ou científica em particular”. Nesse sentido, mesmo considerando a contribuição de Gramsci (1982) para a análise das políticas públicas, não se tomaram suas ideias sem questionamento. Ponderou-se que, no caso da Política de Qualidade, foco desta pesquisa, os interesses da sociedade civil na sua relação com o Estado tende a organizar grupos de interesse, mas tais grupos não parecem trazer consigo a perspectiva de classe social ou objetivos aludidos pela perspectiva gramsciana.

Assumindo tal concepção teórica acerca do conceito de políticas públicas, o Parfor e o Sinaes, nas suas interações, ações e omissões, foram evidenciados como elementos da Política de Qualidade, quando delimitados pelas diretrizes curriculares definidas para o curso de pedagogia. Porém, tais relações não se confundiram com o conjunto das ações individuais de cada programa. A política delineada destacou a interface entre seus elementos na perspectiva de estabelecer a oferta adequada de cursos de pedagogia para a formação de professores da educação infantil e anos iniciais do ensino fundamental. Além disso, considerou, ainda, que tais interações tiveram como quadro de referência a arena de disputas que se estabeleceu a partir das relações entre o Estado e a sociedade, que orientam os movimentos que a define. 
Por isso, na seção que segue, tais interações entre os elementos da Política de Qualidade foram analisadas para maior aproximação sobre a sua dinâmica interna.

\subsection{ELEMENTOS DA POLÍTICA DE QUALIDADE}

Considerando as perspectivas histórica, legal e teórica discutidas, buscou-se nesta seção detalhar os desdobramentos empíricos dos elementos considerados neste trabalho para o delineamento da Política de Qualidade. Dessa forma, foram discutidos aspectos mais representativos do Parfor, do Sinaes e das DCN da licenciatura em pedagogia para a política em foco, procurando evidenciar suas principais características e contribuições em torno do objeto de pesquisa.

\subsubsection{Plano Nacional de Formação de Professores da Educação Básica: formatação e desenvolvimento}

A Política Nacional de Formação dos Profissionais do Magistério da Educação Básica - e, dentro dela, o Parfor - abarcou as iniciativas recentes do Estado brasileiro para superar os déficits de professores qualificados em atuação na educação infantil, no nível fundamental e no nível médio. A necessidade de enfrentamento dessa carência de professores adequadamente formados para atuação na educação básica permitiu à Capes oferecer soluções a um problema real e em evidência, ao mesmo tempo que consolidou o seu papel como agência promotora da formação docente. Nesse sentido, a partir da Lei $n .^{\circ} 11.502$, de 11 de julho de 2007 (BRASIL, 2007a), a Agência, cuja missão era organizar e incentivar a formação de professores da educação superior e pesquisadores, passou a atuar também em prol da formação dos professores da educação básica. Em consequência, conforme apontado por Souza (2014), a Capes praticamente triplicou de tamanho, tanto em número de servidores quanto em dotação orçamentária, diminuindo o risco da reedição de ações como aquelas presentes na Medida Provisória 150/1990, que a extinguiu ${ }^{32}$ (BRASIL, 1990).

O Estatuto da Capes, então aprovado pelo Decreto n. ${ }^{\circ}$ 6.316, de 20 de dezembro de 2007, estabeleceu que a Agência atuasse no fornecimento de subsídios ao MEC para a formulação de políticas e desenvolvimento de atividades de formação de profissionais de magistério para a educação básica e superior, bem como para o desenvolvimento científico tecnológico do País (BRASIL, 2007c). Nesse sentido, foi criado o Conselho Técnico-

\footnotetext{
32 Após intensa mobilização da comunidade acadêmica nacional, a Capes foi recriada por meio da Lei
} 8.405/1992 (BRASIL, 1992). 
Científico da Educação Básica (CTC-EB), órgão colegiado oficialmente designado para a missão de assistir a Capes na construção de um sistema nacional de formação de professores, configurando-se como importante fórum de discussão sobre a nova missão da Agência. Inclusive, foi a partir das discussões, sugestões e embates de ideias no Conselho que se formatou o decreto que definiu a Política Nacional de Formação de Profissionais do Magistério da Educação Básica.

Por outro lado, conforme chamou à atenção Souza (2014), a configuração de forças que contribuíram para as ações do governo brasileiro em prol da institucionalização da política de formação de professores da educação não foi linear: primeiro foram criados programas e ações de forma pulverizada na Capes e Secretarias do MEC e, posteriormente, tais atividades foram institucionalizadas como parte de uma única política pública. Na criação do Parfor, houve a agregação de ações voltadas à formação de docentes que já vinham sendo desenvolvidas no MEC, sem que, necessariamente, elas tivessem sido organicamente integradas. Por isso, mesmo fazendo parte do mesmo plano de formação, os cursos a distância de formação inicial e continuada de docentes continuaram a ser gerenciados pelo Sistema Universidade Aberta do Brasil (UAB), enquanto os cursos de formação continuada presenciais se mantiveram sob a responsabilidade direta da Secretaria de Educação Básica do MEC. Seguindo essa lógica, a oferta de licenciaturas presenciais foi individualizada como um programa específico, com gestão e financiamento independentes dos demais, criando-se, então, o Parfor Presencial. Dessa forma, a portaria que criou o Parfor (BRASIL, 2009b), ao contrário de organizar em um corpo único as ações de formação inicial e continuada de professores, permitiu a manutenção de sua segmentação. O citado documento legal garantiu apenas a referência ao conjunto dessas ações formativas como Parfor, sem que mecanismos efetivos de integração entre elas fossem estabelecidos.

Assim, corroborando as características de políticas públicas aludidas por Marques (1999), a falta de linearidade da política de formação docente permitiu caracterizar as ações recentemente empreendidas pelo governo brasileiro para o enfrentamento do problema de falta de qualificação dos docentes como pouco articuladas. Os movimentos em prol dessa articulação, como a criação pelo MEC, por meio da Portaria n. ${ }^{\circ}$ 1.087, de 10 de agosto de 2011, do Comitê Gestor da Política Nacional de Formação Inicial e Continuada de Profissionais da Educação Básica (BRASIL, 2011b), apresentaram resultados que foram classificados apenas como burocráticos por Souza (2014).

O primeiro ato desse Comitê foi determinar, por meio da Resolução n. ${ }^{\circ}$ 1, de 17 de agosto de 2011, que as IES participantes da política de formação de professores para a 
educação básica instituíssem comitês locais para gerenciar as ações do Parfor (BRASIL, 2011f). Contudo, concretamente, essa resolução versou sobre o pagamento de bolsa ao responsável pelo comitê local, sobrepondo-o aos coordenadores da UAB e do Parfor Presencial já nomeados localmente, sem que mecanismos de integração entre suas ações tivessem sido estabelecidos.

Nesse sentido, ante essa desarticulação, associada à centralidade que o Parfor Presencial assumiu nesta pesquisa, cumpre esclarecer que a finalidade desse programa, em específico, é oferecer cursos presenciais para que os professores da rede pública de educação básica alcancem a formação em nível superior exigida pela LDB vigente. A sua criação fundamentou-se nos incisos III do art. 11 e IV do art. $3 .^{\circ}$ da política de formação docente (BRASIL, 2009a), que induziu a oferta emergencial de cursos dirigidos aos docentes em exercício há pelo menos três anos na rede pública de educação básica que não tivessem formação em nível superior (primeira licenciatura), que atuassem em áreas distintas da sua formação inicial (segunda licenciatura) ou que não tivessem habilitação em licenciatura (formação pedagógica). Entre os benefícios previstos destacaram-se: a oferta gratuita de cursos aos professores da rede pública de educação básica, bolsas aos professores-formadores e fomento à oferta de cursos, por meio de verbas de custeio e capital às IES.

Tomando como referência Boschetti (2009), essa configuração pôde ser caracterizada pela perspectiva de continuidade, uma vez que foi instituída legalmente. Além disso, o Parfor Presencial caracterizou-se por ter sido implementado sob a ótica do direito, respeito às regras previamente definidas e por oferecer um benefício não contributivo, independentemente da participação financeira dos beneficiários. Por fim, apresentou caráter seletivo e focalizado, abrangendo um público determinado - professores das redes públicas de educação básica não diplomados em nível superior.

No que se referiu aos caminhos de acesso aos benefícios do programa, Souza (2014) identificou três dimensões: instituições de educação superior e entes da federação, por meio da adesão aos Fóruns Estaduais Permanentes de Apoio à Formação Docente; cursos (e quantidade de vagas disponibilizadas), via plano estratégico construído no âmbito dos Fóruns Estaduais para mapear as necessidades de formação de professores na unidade da federação em relação à capacidade de atendimento das IES envolvidas; professores-aprendizes selecionados pelas IES por sorteio ou processo seletivo desde que fossem docentes em exercício há, pelo menos, três anos na rede pública de educação básica, graduados não licenciados; licenciados em área diversa da atuação docente; ou de nível médio. 
A gestão do Parfor, e dentro dele o Parfor Presencial, foi definida pela política de formação docente (BRASIL, 2009a) para ocorrer por meio dos Fóruns Estaduais Permanentes de Apoio à Formação Docente. Assumindo o perfil de órgão colegiado, esses Fóruns foram regulamentados para organizar o Parfor em regime de colaboração entre a União, os Estados, o Distrito Federal e os Municípios. Conforme estabelecido pela Portaria n. ${ }^{\circ} 883$, de 16 de setembro de 2009, participam da composição dos Fóruns representantes dos Estados (Secretarias de Educação, que em geral os preside), do MEC, das IES e de várias entidades ligadas aos municípios, trabalhadores da educação e acadêmicos, bem como aquelas interessadas ou que estudam o tema educacional e queiram fazer adesão (BRASIL, 2009c).

Apesar de esse modelo de gestão valorizar a ampla participação da sociedade civil organizada, denotando compromisso com princípios democráticos e federativo na condução do plano de formação docente, seus resultados foram questionados. Com base na análise realizada a partir desta pesquisa e publicada na Revista Brasileira de Educação, foi possível considerar a pouca efetividade do trabalho dos Fóruns para garantir equidade do acesso de professores ao Parfor, notadamente no Parfor Presencial, tendo em vista: i) a baixa frequência de reuniões estabelecidas ordinariamente pela legislação quando confrontada com a complexa atividade de elaboração do plano estratégico de formação inicial e continuada dos docentes em cada Estado; ii) a inexistência de previsão legal que permitisse a articulação das ações dos Fóruns com o trabalho do Comitê Gestor do Parfor, instituído pelo MEC em 2010, ou com o CTC-EB da Capes; e iii) a má distribuição de vagas dos cursos do Parfor em relação às carências apresentadas pelas unidades da federação. (SOUZA, 2014).

Conforme demonstraram os dados sistematizados no Gráfico 4, em janeiro de 2012 , 65\% dos alunos matriculados no Parfor Presencial estavam concentrados em apenas quatro unidades da federação ( Pará, Bahia, Maranhão e Piauí). Em sete estados (Mato Grosso, Mato Grosso do Sul, Acre, Sergipe, Alagoas, Goiás e Espírito Santo) mais o Distrito Federal, o percentual de matrículas correspondeu a cerca de $1 \%$ do total. Com isso, constatou-se uma aparentemente hiperconcentração das atividades do programa, sem que tivesse sido possível identificar o real sentido de sua distribuição no território nacional para superar os déficits de professores com formação adequada. 
Gráfico 4 - Percentual de matrículas por UF no Parfor Presencial - janeiro/2012.

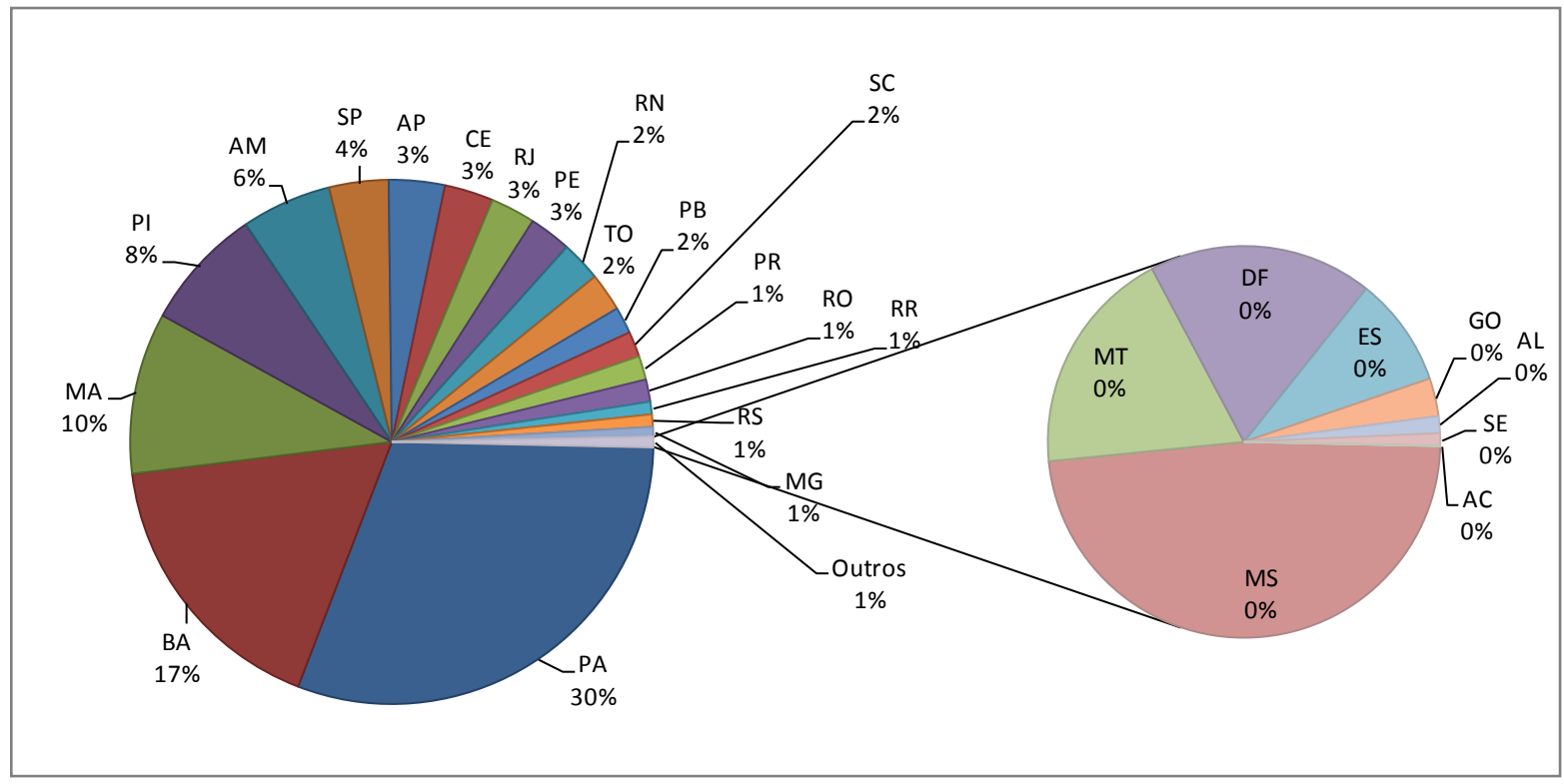

Fonte: Diretoria de Educação Básica/Capes (Plataforma Freire).

Ao se observar o Gráfico 4 em comparação com o Gráfico 5 (que traz o mapa da distribuição dos professores não licenciados entre as unidades da federação), constataram-se algumas disparidades entre os estados nos quais houve concentração de matrículas do Parfor e aqueles que concentravam o maior número de professores em suas redes de educação básica sem a formação exigida pela LDB.

Gráfico 5 - Distribuição dos professores da educação básica sem formação superior por UF - 2009.

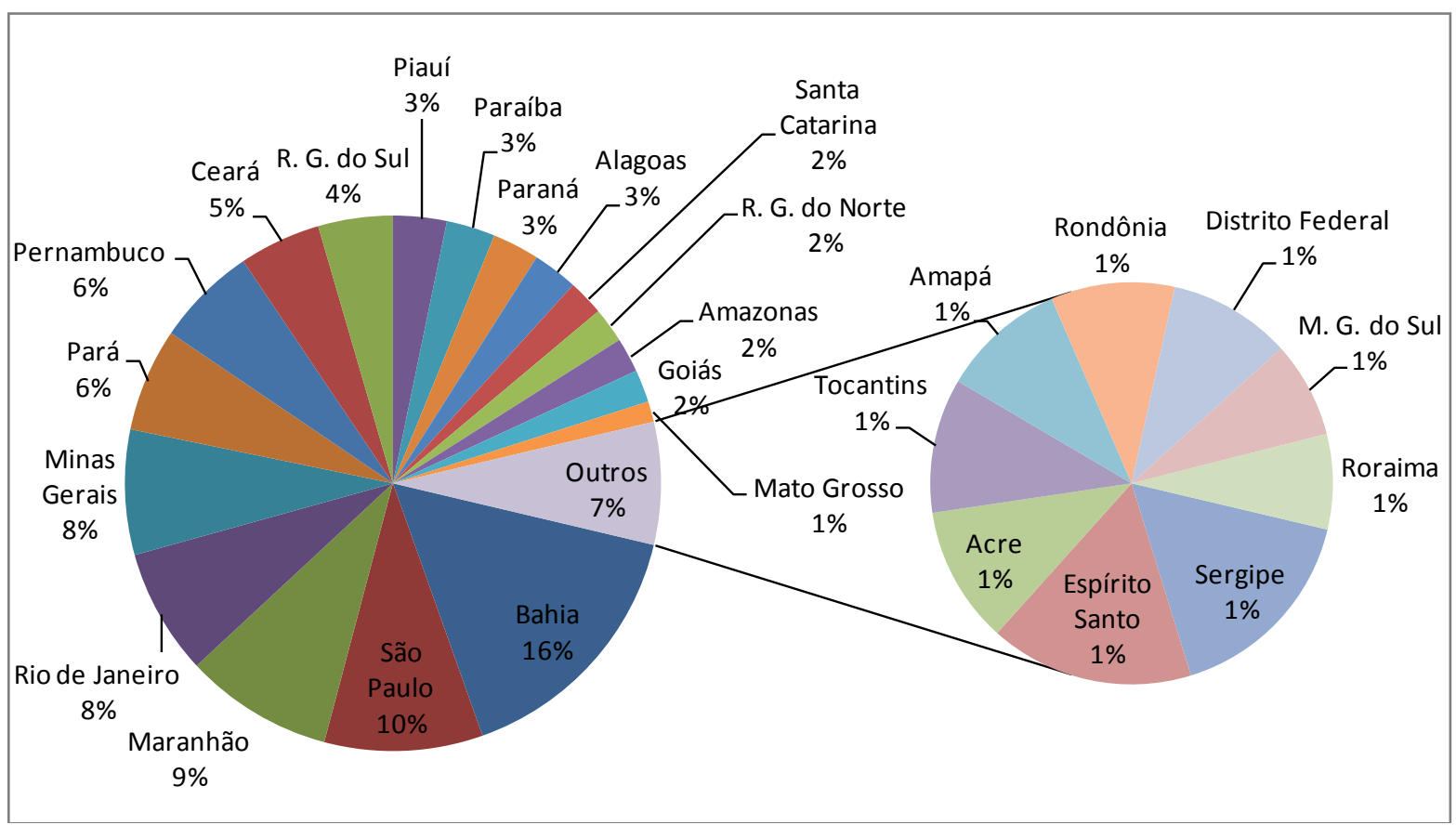

Fonte: Inep/Sinopse Estatística do Professor da Educação Básica, 2009 (INEP, [2009?b]). 
Pelos dados apresentados no Gráfico 5, seria esperado que São Paulo, Rio de Janeiro, Minas Gerais, Pernambuco e Ceará estivessem tão bem contemplados na distribuição de matrículas do Parfor quanto Bahia, Pará e Maranhão. No seu conjunto, esses oito estados contabilizavam 58\% dos quase 630 mil professores brasileiros sem formação em nível superior. Já o Piauí, que tem apenas 3\% do total nacional de professores não licenciados, ficou posicionado na quarta colocação entre os Estados com maior concentração de professores no Parfor, contabilizando $8 \%$ do número das matrículas (Gráfico 4). A título de comparação, o Rio Grande do Sul que tinha, em 2009, 4\% do total de professores brasileiros sem a formação mínima exigida pela $\mathrm{LDB}$, só participou com $1 \%$ do total de professores matriculados no Parfor.

Adicionalmente, a comparação entre os dados apresentados pelos Gráficos 4 e 5 não foi capaz de justificar a concentração de matrículas do Parfor Presencial no estado do Pará. Esse estado respondia sozinho, em janeiro de 2012, por cerca de 30\% dos alunos do Programa - quase o dobro das matrículas da Bahia, na segunda posição. No entanto, em 2009, o Pará possuía apenas $6 \%$ do total nacional de professores com déficit de formação, atrás da Bahia, São Paulo, Maranhão, Rio de Janeiro e Minas Gerais.

Supondo que talvez os critérios para a concentração das matrículas do Parfor Presencial em poucas unidades federativas fossem justificados pela comparação entre o número de professores sem qualificação dentro do próprio universo de docentes de cada uma delas, resolveu-se reorganizar os dados nesse sentido. Porém, ainda assim, não foi possível encontrar justificativas empíricas para a distribuição de matrículas apresentadas pelo Parfor, como é possível observar no Gráfico 6. 
Gráfico 6 - Percentual de docentes da educação básica sem formação superior no Brasil e por UF - 2009.

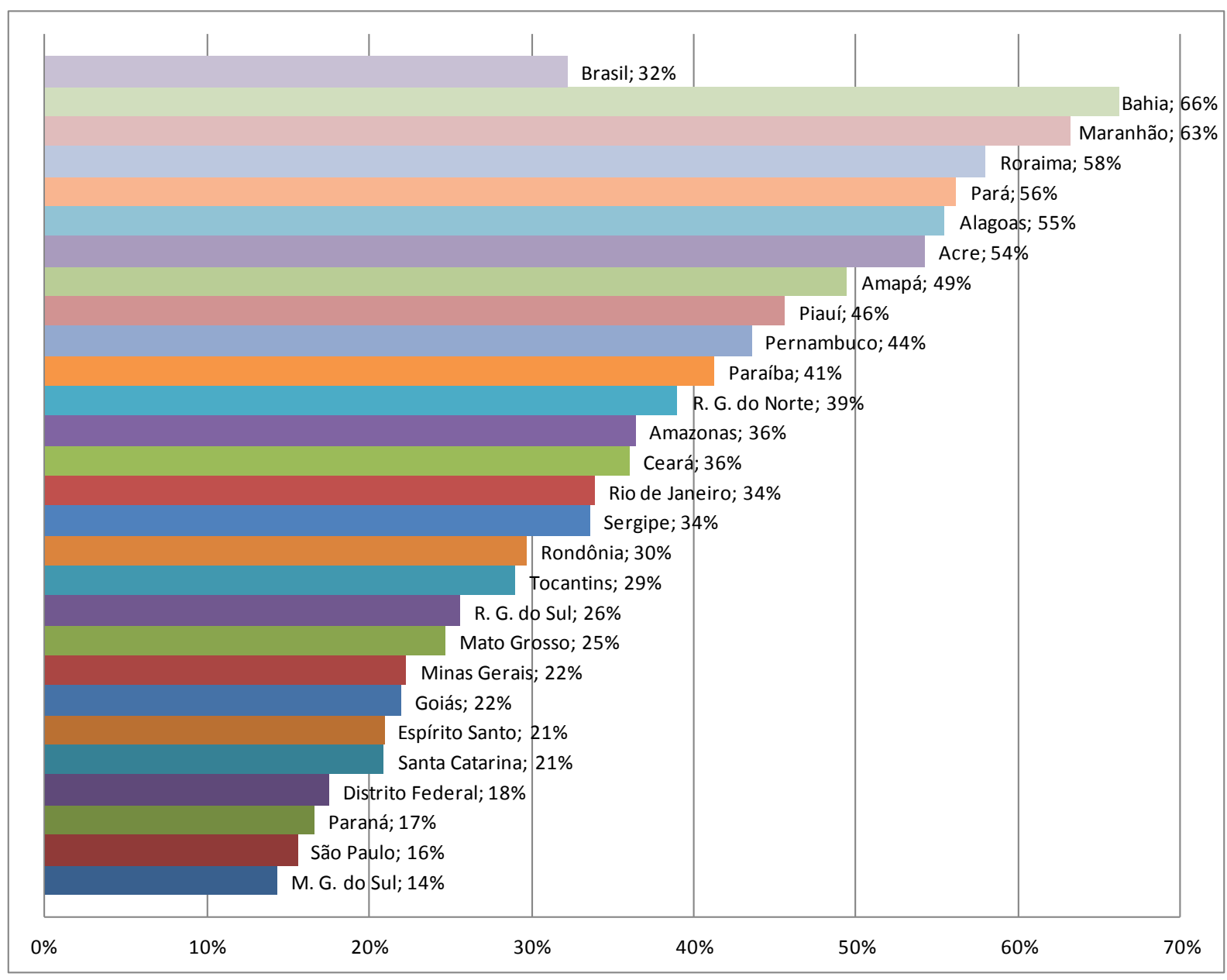

Fonte: Inep/Sinopse Estatística do Professor da Educação Básica, 2009. (INEP, [ 2009?b])

De acordo com esses dados, na média, o Brasil possuía, em 2009, um índice de $32 \%$ de professores sem formação superior. Essa medida é muito próxima à mediana de $34 \%$ que distribuiu igualmente os estados entre os grupos daqueles que possuem mais docentes atuando na educação básica sem formação superior e aqueles que possuem menos docentes atuando nessas condições, significando que a média não está sendo distorcida nem por um grupo, nem por outro. Tomando-se essa informação e considerando o índice médio como referência, identificou-se que os quatro estados mais bem contemplados com matrículas do Parfor Presencial estão no grupo daqueles com os maiores índice de docentes sem formação superior. Porém, eles não estão sós. Sendo assim, estados como Acre, Alagoas, Roraima, Rio Grande do Norte e Paraíba precisariam estar mais bem contemplados no número de matrículas do Parfor Presencial, algo que não ocorreu no período ao qual se referem os dados.Quando se observou a questão da qualidade da oferta dos cursos presenciais de licenciatura em pedagogia do Parfor, evidenciaram-se os pontos de contato com o Sinaes e com as DCN do curso, no que se denominou Política de Qualidade. No caso Sinaes, os resultados dos seus 
processos avaliativos têm sido utilizados no âmbito do Parfor Presencial como requisito a ser atendido pelo curso presencial de iniciação à docência para dele fazer parte. No caso das DCN da licenciatura em pedagogia, elas além de orientarem a oferta do Parfor, dão subsídios às avaliações do Sinaes.

De acordo com as regras do Parfor Presencial, no caso dos cursos pertencentes ao Sistema Federal de Ensino Superior, exige-se conformidade ao Sistema de Regulação do Ensino Superior (E-MEC), com nota da avaliação de curso ou, na sua ausência, nota da avaliação de instituição igual ou superior a três. No caso de IES do sistema estadual e municipal, se o curso não estiver cadastrado no E-MEC, admite-se a sua participação no plano de formação, mediante autorização do curso emitida pelo órgão responsável e aprovação pela Capes (CAPES, 2014). Com isso, identificou-se que a proposta de formação do programa não obedeceu a qualquer diretriz acadêmica, deixando a operacionalização das DCN da licenciatura em pedagogia sob o encargo das diversas IES participantes da formação de professores da educação infantil e anos iniciais do ensino fundamental de forma pulverizada.

Porém, assumir a simples regulação do Sinaes para esses cursos não pareceu ser capaz de substituir tal diretriz, tendo em vista que a regulação feita pelo sistema avaliativo não abrangeu toda a oferta. Além disso, tal opção não permitiu ao Parfor oportunidade de reflexão sobre problemas conceituais e práticos de um programa dessa natureza, entre os quais se destacaram: i) o perfil diferenciado do aluno (professor em serviço); ii) o projeto pedagógico e a abordagem metodológica para atender professores, no exercício da docência, mas sem a formação inicial; e iii) os tempos de formação - uma vez que os professores-alunos continuaram com suas atividades em sala de aula nas redes públicas de educação básica para participarem dos cursos.

Assim, a despeito da necessidade de um projeto de curso que pudesse refletir a especificidade da formação dos docentes da educação básica e a organicidade ao trabalho das diferentes IES que concorreram para essa formação, não foram encontradas diretrizes que pudessem orientar a oferta dos cursos do Parfor em geral, e em específico daqueles pertencentes à área de pedagogia, em análise nesta tese. Nesse sentido, as ações das IES na organização didático-pedagógica dos cursos do Parfor ficaram a cargo das orientações presentes nas DCN do curso, bem como na regulação promovida pelas avaliações Sinaes, quando pertinentes. 


\subsubsection{DCN da licenciatura em pedagogia: embates conceituais}

Nesta pesquisa, as DCN do curso de pedagogia foram entendidas como elemento chave para discutir a relação estabelecida entre Parfor e Sinaes no âmbito da Política de Qualidade, na medida em que estabeleceram orientações tanto para a oferta quanto para a avaliação dos cursos para a formação de professores da educação infantil e dos anos iniciais do ensino fundamental. Considerando esse argumento, a análise do processo de formulação e implantação desse documento legal ofereceu a oportunidade de destacá-lo como um dos elementos estruturantes da política em foco.

A idealização e a implantação das diretrizes curriculares do curso foram permeadas por um princípio básico: o da base docente. Esse princípio emergiu do movimento dos educadores organizados pela Anfope, a partir da concepção da docência como o foco principal da formação do pedagogo, com vistas à superação da dicotomia entre a licenciatura e o bacharelado, então identificada (LIBÂNEO, 2006). Em linhas gerais, a proposta da base docente ampliou o sentido da docência para o pedagogo, assumindo que esta, além do ato de ministrar aulas, compreenderia a participação do egresso da pedagogia nas atividades de organização e gestão de sistemas e instituições formais e não formais de educação (AGUIAR et al. 2006).

Segundo Libâneo (2006), o movimento em prol da formação do pedagogo fundada na base docente foi calcado no desenvolvimento de conhecimento mais abrangente e integrador sobre a escola e a organização do trabalho pedagógico. Nesse sentido, as disciplinas do curso deveriam estar voltadas notadamente à docência nos anos iniciais do ensino fundamental e da educação infantil, agregando os conteúdos mais afetos à formação do especialista, de modo a fazer com que o futuro professor tivesse condições de participar também das funções de direção e coordenação. Nesse sentido, apresentou a docência como formação prioritária do pedagogo e, a partir dela, o desenvolvimento dos demais conhecimentos necessários à gestão da educação. Assim, a tese da base docente propôs embasar o desenvolvimento profissional do pedagogo a partir da sua identidade como professor, passando a ser fortemente defendida quando da concepção das DCN para o curso de pedagogia.

O sentido ampliado da profissionalidade do pedagogo trazida pela ideia da base docente superou o simples desenvolvimento da competência de ministrar aulas pelo egresso do curso. Essa perspectiva transbordou o sentido comum da atividade de professor, na tentativa de incorporar perfis até então distintos: o licenciado e o especialista em educação. Com isso, prevaleceu a ideia de que a base docente promoveria a agregação de conteúdos até 
então concorrentes, de forma a contemplar tanto as disciplinas afetas ao que, como e por que ensinar quanto àquelas ligadas à gestão pedagógica e administrativa da escola, aos sistemas educacionais e aos espaços não escolares de aprendizagem, bem como à pesquisa e à difusão de conhecimentos pedagógicos.

Assim, tendo como referência a base docente, a organização curricular dos cursos de pedagogia foi operacionalizada por meio dos núcleos de estudos, assim definidos: a) núcleo de estudos básicos - centrado em conteúdos comuns ao docente da educação infantil e dos anos iniciais do ensino fundamental e ao especialista em educação, bem como naqueles específicos de cada um desses perfis; b) núcleo de aprofundamento e diversificação de estudos - seguindo as especificidades de cada instituição e dos interesses dos alunos em uma das áreas previstas para a atuação do pedagogo; e c) núcleo de estudos integradores - mais voltado à prática dos alunos.

Para Scheibe e Aguiar (1999), a concepção do núcleo de estudos básicos propôs a organização da estrutura curricular da pedagogia de forma a contemplar igualmente tanto os conteúdos relativos às ciências da educação quanto aqueles relacionados ao contexto da educação básica. Nesse sentido, os fundamentos filosóficos, históricos, políticos, econômicos, sociológicos, psicológicos e antropológicos necessários à reflexão crítica sobre a educação na sociedade contemporânea deveriam figurar ao lado das teorias pedagógicas e suas articulações com a didática e com as tecnologias de informação e comunicação (TIC). Também deveriam ser contemplados temas relativos ao trabalho pedagógico, à gestão e à coordenação educacional, bem como às relações entre educação e trabalho e ao contexto do exercício profissional em âmbitos escolares e não escolares.

Já o núcleo de estudo de aprofundamento deveria atender às necessidades de diversificação na formação do pedagogo, sendo aprofundada e verticalizada em duas perspectivas: a) conteúdos da educação básica - foco na atuação docente; e b) conteúdos voltados às outras áreas de atuação profissional priorizadas no projeto pedagógico da IES. Por fim, o núcleo de estudos integradores permitiria o desenvolvimento de atividades práticas (monitorias e estágios, programas de iniciação científica, etc.) com os conhecimentos construídos nos dois núcleos anteriores (SCHEIBE; AGUIAR, 1999).

No entanto, pôde-se observar que a perspectiva ampliada da atividade docente presente nas DCN da licenciatura em pedagogia não ofereceu um caminho fácil para as instituições formadoras fixarem o currículo dos seus cursos. Da forma como o núcleo de estudos básicos foi definido não houve uma perspectiva interdisciplinar de organização do 
conhecimento, no qual os eixos de conteúdos pudessem tratar de forma integrada o trabalho do professor e do especialista.

Conforme pontuou Libâneo (2006), ao mesmo tempo que o texto das DCN eliminou a possibilidade do aprofundamento disciplinar do conhecimento por meio das habilitações, estabeleceu que um mesmo curso de licenciatura fosse capaz de formar professores para atuação em várias modalidades de ensino (educação infantil, anos iniciais do ensino fundamental, cursos normais de nível médio, cursos de educação profissional na área de serviços e apoio escolar), além da atuação como especialistas nas funções de orientação, direção, etc. Para o autor, não existiram garantias de que a estrutura do curso pudesse atender uma formação tão ampla do profissional para atuar na docência, na gestão e na pesquisa educacional.

Evidenciou-se, pois, como ponto nevrálgico da base docente na organização curricular do curso de pedagogia, o tempo necessário à formação do egresso com esse perfil ampliado. A esse respeito, Libâneo (2006, p. 861) foi categórico em duvidar que o curso com um mínimo de 3.200 horas, conforme foi previsto, pudesse formar "professores para três funções que têm, cada uma, sua especificidade: a docência, a gestão, a pesquisa, ou formar, ao mesmo tempo, bons professores e bons especialistas, com tantas responsabilidades profissionais a esperar tanto do professor como do especialista".

Apesar desses contra-argumentos, a organização curricular a partir dos três núcleos de estudos anteriormente citados foi aprovada pelo Conselho Nacional de Educação (CNE) por meio da Resolução CNE/CP n. ${ }^{\circ}$ 1, de 15 de maio de 2006 (BRASIL, 2006b), concretizando, pelo menos em tese, a perspectiva da base docente para a estruturação e oferta dos cursos. Nesse processo, foram realizados diversos encontros, fóruns de discussão e apresentações para o amadurecimento da proposta delineada em 1999 pela Comissão de Especialistas de Ensino de Pedagogia, ${ }^{33}$ conforme relatado por Aguiar et al. (2006). Por outro lado, considerando que no campo da formação de professores não se tinha um consenso sobre a pertinência dessa proposta, pode-se supor que a base docente foi implantada, seguindo a dinâmica apontada por Marques (1999) sobre como ocorre a influência das redes de especialistas nas ações de governo.

\footnotetext{
${ }^{33}$ De acordo com Scheibe (2007), essa Comissão foi nomeada pela Portaria SESu/MEC n. ${ }^{\circ} 146$, de 10 de março de 1998, e teve como membros Celestino Alves da Silva (Universidade Estadual Paulista - Unesp/Marília); Leda Scheibe, presidenta (Universidade Federal de Santa Catarina - UFSC); Márcia Ângela Aguiar (Universidade Federal de Pernambuco - UFPE), Tizuko Morchida Kishimoto (Universidade de São Paulo USP) e Zélia Mileo Pavão (Pontifícia Universidade Católica - PUC/PR).
} 
A mudança de orientação política no governo federal brasileiro, ocorrida em 2003, realinhou a capacidade de influência do movimento dos educadores, contando com a permeabilidade necessária à implantação da perspectiva de base docente na estruturação dos cursos de pedagogia. Esse argumento se justificou tendo em vista a mudança do antigo partido político responsável pela condução da política educacional, que até então, vinha promovendo o curso normal superior, e não o de pedagogia, como o responsável pela formação de professores da educação infantil e dos anos iniciais do ensino fundamental. Com o novo governo, houve espaço para que os grupos que compartilhavam da ideia da base docente e do fortalecimento do curso de pedagogia ganhassem força em relação àqueles que preferiam o curso normal superior para essa missão formativa.

Nesse sentido, as diretrizes de formação de professores, aprovadas por meio da Resolução CNE/CP n. ${ }^{\circ}$ 1, de 18 de fevereiro de 2002, quase ao apagar das luzes do governo do Fernando Henrique Cardoso (BRASIL, 2002), teve sua implantação protelada por meio da Resolução CNE/CP n. ${ }^{\circ}$, de 27 de agosto de 2004 e da Resolução CNE/CP n. ${ }^{\circ}$, de 17 de novembro de 2005 (BRASIL, 2004b; 2005) até quando foi possível realinhar o ordenamento legal à proposta da base docente, aprovado para o curso de pedagogia pela Resolução CNE/CP n. ${ }^{\circ}$, de 15 de maio de 2006, e estendido ao curso normal superior (BRASIL, 2006b). Uma vez aprovadas, as diretrizes curriculares específicas para os cursos de pedagogia eliminaram de fato a possibilidade de organização do curso normal superior, mesmo estando vigentes as referências a esse tipo de curso no art. 63 da Lei n. ${ }^{\circ}$ 9.394, de 20 de dezembro de 1996 (BRASIL, 1996), na Resolução CNE/CP 1, de 30 de setembro de 1999 (BRASIL, 1999b), bem como no Decreto 3.554, de 7 de agosto de 2000 (BRASIL, 2000).

Pontua-se, no entanto, que a ideia de formar o pedagogo - entendido historicamente como especialista em educação - conforme alínea c do art. 51 do Decreto-Lei n. ${ }^{\circ} 1.190$, de 4 de abril de 1939 (BRASIL, 1939) - por meio dos conteúdos diretamente afetos à docência, trouxe também embutida a sua perspectiva inversa: a formação do docente considerando a necessidade de conhecimento de gestão da educação em espaços escolares e não escolares. No entanto, essa perspectiva inversa da base docente, apesar de trazer impactos para a concepção de docência no campo das demais licenciaturas, não foi objeto de análise ou discussões de especialistas.

Assim, por um lado, considerou-se como relevante a preocupação do movimento dos educadores em prol da base docente, na medida em que, do ponto de vista do curso de pedagogia, não traria prejuízos ao especialista em educação enriquecer sua formação ao vivenciar a experiência docente, apropriando-se das virtudes e vicissitudes do magistério 
como objeto do próprio trabalho de gestor. Por outro, do ponto de vista da formação dos docentes da educação infantil e dos anos iniciais do ensino fundamental, não ficou claro como a ocorrência de conteúdos afetos à gestão de espaços escolares e não escolares - nos termos da docência ampliada presente em Aguiar et al. (2006) e no art. 4. ${ }^{\circ}$ das DCN da pedagogia (BRASIL, 2006b) - contribuiriam com as atribuições do futuro professor em sala de aula.

A análise dessas DCN conduziu ao entendimento de que a formação do especialista se sobrepõe à formação do professor. Nessa perspectiva, poder-se-ia imaginar essa configuração pela agregação de todos os conteúdos teóricos do especialista e do professor de maneira superficial, numa perspectiva generalista, ou pelo aprofundamento de aspectos específicos da atuação do pedagogo (seja como professor, seja como especialista), conforme o interesse dos alunos e as propostas das instituições. Porém, tais possibilidades de desenvolvimento do currículo dos cursos de pedagogia suscitam dúvidas sobre os critérios de qualidade que devem ser assumidos pelas IES na oferta do Parfor e pelo Sinaes na avaliação dos cursos dessa área. As discussões travadas no âmbito do Conselho Nacional de Educação (CNE), assim como os votos em separado de alguns conselheiros, denotaram questionamentos sobre benefícios, limitações e a estruturação prática de um curso que pretende formar - ao mesmo tempo professores para os anos iniciais da educação básica e especialistas em administração, planejamento, inspeção, supervisão e orientação educacional.

Esses questionamentos foram ainda mais aguçados em função da possibilidade de se permitir uma formação pouco consistente do professor e do especialista em educação, tendo em vista a complexidade em se lidar com conteúdos específicos dessas duas áreas formativas. Os resultados apresentados por Gatti (2009, p.54) ilustraram em parte esse entendimento, pois destacaram, entre outros pontos, a reduzida capacidade de os cursos de pedagogia desenvolverem nos egressos "habilidades profissionais específicas para a atuação nas escolas e nas salas de aula [...]”, em função da grande quantidade de disciplinas variadas e gerais, bem como aquelas de caráter de formação genérica.

Esses resultados, além de corroborarem a preocupação em destaque, acenderam um sinal de alerta sobre a qualidade dos cursos de pedagogia, principalmente porque no âmbito da avaliação da qualidade do curso, não se encontraram garantias de correções das distorções apontadas por Gatti (2009, 2010). De acordo com Souza (2013, p. 11), a análise do conteúdo das provas do Enade nas edições de 2005, 2008 e 2011 apontou uma "frequência relativa menor dos conteúdos ligados à 'docência' [25\%] e à formação 'específica: gestão escolar e outros espaços educativos' [10\%], em relação àqueles de 'formação geral' [64\% das questões] 
quando se esperava, pelo menos, um equilíbrio desses três domínios de conteúdos [no Exame]".

Assim, as possibilidades de organização dos cursos de pedagogia e do processo avaliativo do curso permitiram reflexões sobre a convergência, ou não, dos critérios de qualidade do Parfor e do Sinaes. Tais reflexões apontam para o entendimento de que a ideia da base docente foi assumida pelo Estado brasileiro no âmbito das Diretrizes Curriculares do curso de pedagogia como princípio estruturante para a formação com qualidade do seu egresso. Porém, considerando os questionamentos de Franco, Libâneo e Pimenta (2007) e Libâneo (2006) em torno dessa ideia e dos resultados até agora encontrados por Gatti (2009, 2010) e por Souza (2013), não há garantias de que a permeabilidade que a base docente obteve no âmbito do CNE venha se reproduzindo concretamente em outras esferas, notadamente naquelas que envolvem o Parfor e o Sinaes.

\subsubsection{Sistema Nacional de Avaliação da Educação Superior: configuração e objetivos}

O Sinaes foi estruturado pela Lei n. ${ }^{\circ}$ 10.861, de 14 de abril de 2004 (BRASIL, 2004a), a partir de três componentes: Avaliação das Instituições de Educação Superior, Avaliação dos Cursos de Graduação e Avaliação do Desempenho dos Estudantes (Enade). Esse sistema avaliativo se configurou como o referencial básico para a tomada de decisão sobre o Sistema Federal de Ensino Superior, ${ }^{34}$ uma vez que foi por meio dele que o poder público se propôs a regular o referido nível educacional, orientando a expansão da sua oferta, o alcance dos objetivos pretendidos pelas instituições de educação superior, bem como a produção de efeitos acadêmicos e sociais. No parágrafo $1 .^{\circ}$ do art. $1 .^{\circ}$ da referida lei que criou o Sinaes, está previsto, ainda, que ele deve promover o aprofundamento do compromisso e da responsabilidade das IES no cumprimento da sua missão pública, dos valores democráticos e do respeito à diferença e à diversidade, bem como na afirmação da sua autonomia e identidade institucional.

Considerando essa perspectiva, pode-se inferir que esse sistema, simultaneamente, serviu de subsídio para a regulação da educação superior pelo Estado e representou, em certa medida, uma proposta de autorregulação institucional, por meio dos subsídios à gestão interna das IES proporcionados pelos resultados do processo avaliativo. Essa aparente ambiguidade sobre os usos da avaliação do Sinaes entre funções regulatórias e de cunho emancipador foi

\footnotetext{
${ }^{34}$ Relembrando informação já apresentada, o art. $2^{\circ}$ do Decreto n. ${ }^{\circ} 5.773$, de 9 de maio de 2006 (BRASIL, 2006a), não inclui IES estaduais e municipais nesse sistema.
} 
tratada por Barreyro e Rothen (2006) a partir da constatação de que tais funções da avaliação contrapõem modelos teóricos contraditórios:

[...] diferentes autores têm desenvolvido estudos e modelos teóricos para analisar esses usos da avaliação. Na América Latina: avaliação como controle versus avaliação como produção de sentidos/emancipatória (DIAS SOBRINHO, 2002), avaliação como garantia pública de qualidade versus avaliação para a melhoria da qualidade (STUBRIN, 2005), avaliação como regulação versus avaliação democrática (CONTERA, 2002), entre outros (p. 957).

A partir da polarização da avaliação entre as perspectivas emancipatórias e de regulação trazidas pelos autores, foi possível considerar que o processo de implantação do Sinaes tenha sido permeado pelo embate de ideias entre especialistas sobre seu modelo de avaliação. Com isso, tornou-se necessário evidenciar as discussões teóricas subjacentes ao processo de estruturação do Sinaes, de forma a explicitar as perspectivas de análise que concorreram e ainda concorrem para sua materialização como política pública.

Na discussão realizada por Barretto (2001) sobre avaliação no contexto da educação básica, o modelo emancipatório emergiu da análise crítica sobre a prática avaliativa e se estruturou pelo destaque à necessidade de variáveis de processo voltadas à formação e à transformação. Segundo a autora, esse modelo se contrapôs à perspectiva das variáveis de produto (presentes na realidade do sistema montado no Brasil em meados da década de 1990), cujo foco tinha uma perspectiva regulatória e de ranqueamento. Conforme afirmou, o modelo emancipatório propôs relações mais democráticas e menos hierarquizadas entre os envolvidos no processo avaliativo, além de deslocar o foco do desempenho dos alunos em exames nacionais - presente no modelo regulatório - para o as condições da oferta de cursos, sua organização didático-pedagógica e formação do seu corpo docente (BARRETTO, 2001).

Por outro lado, apesar de as análises sobre avaliação colocarem mais comumente a polarização das perspectivas de regulação x emancipação, bem como de indicadores quantitativos x qualitativos, há que se destacar que também foi possível visualizá-los teoricamente de forma complementar. Com isso, um mesmo processo avaliativo poderia ser considerado como responsável por gerar resultados úteis tanto à regulação estatal quanto ao processo de autorreflexão institucional na busca autônoma de sua qualidade. Paralelamente, os aspectos quantitativos e qualitativos dos indicadores de uma mesma realidade poderiam ser agregados, e não excluídos, para que pudessem descrevê-la de forma mais completa e próxima do que ocorre na prática. 
Nesse sentido, Barretto (2001), mesmo reconhecendo as matrizes ideológicas divergentes entre os modelos de avaliação para a regulação e de avaliação para a emancipação, sinalizou que ambos poderiam adotar procedimentos e recomendações comuns e complementares. A autora alertou, ainda, sobre a necessidade de se tomar as funções de regulação e emancipação do processo avaliativo a partir de uma ótica que superasse a visão parcial da avaliação. Segunda ela, tal visão tende a imputar o caráter "progressista" aos indicadores de processos, enquanto rotula de "conservadores" os indicadores centrados em resultados, quando, em essência, ambos seriam igualmente válidos e necessários aos processos avaliativos.

Contudo, foi a perspectiva de polarização entre os modelos emancipador e regulador que contextualizou o nascimento do Sinaes em 2004, apontando a seguinte contradição: se ele se contrapôs ao modelo regulatório, por que, então, os seus resultados seriam utilizados para a regulação, subsidiando o credenciamento e recredenciamento de instituições, a autorização, o reconhecimento e a renovação de reconhecimento de cursos? Como resposta a esse dilema, a edição do Decreto n. ${ }^{0}$ 5.773, de 9 de maio de 2006 (BRASIL, 2006a), também chamado de "decreto ponte", promoveu uma tentativa de solucionar a disputa entre as perspectivas de avaliação para emancipação e para regulação do Sistema, trazendo de forma confusa, contraditória e não aplicada, a ideia de duas avaliações: uma para a regulação e a outra, a do Sinaes propriamente dito.

Tal tentativa de separação dos dois modelos de avaliação (regulador x emancipador) se evidenciou nas competências estabelecidas pelo referido decreto para a atuação dos diversos atores no âmbito do MEC. Conforme redação dada ao art. 5. ${ }^{\circ}$ - incisos III e IV dos parágrafos $2 .^{\circ}, 3 .^{\circ}$ e $4 .^{\circ}$ e incisos IV e V do parágrafo $6 .^{\circ}$ do referido decreto - as Secretarias do MEC e o CNE seriam os responsáveis pela elaboração de diretrizes para a construção, pelo Inep, dos instrumentos de avaliação para credenciamento de instituições de educação superior e dos instrumentos de avaliação para autorização e reconhecimento de cursos. Já a Comissão Nacional de Avaliação da Educação Superior (Conaes) seria a responsável por estabelecer diretrizes para a elaboração pelo Inep dos instrumentos de avaliação de cursos de graduação e de avaliação interna e externa de instituições, conforme art. 8. (incisos II e IV) do "decreto ponte" (BRASIL, 2006a). Com isso, foi possível entrever nos termos do referido decreto que o Inep seria o responsável por construir dois instrumentos distintos de avaliação: (i) para a regulação, sob responsabilidade das Secretarias do MEC e do CNE, e (ii) para a avaliação [emancipadora] - que poderia ser entendida como o próprio Sinaes - sob responsabilidade da Conaes. 
Essa perspectiva de dois processos avaliativos trazida pelo decreto em análise também foi observada por Barreyro e Rothen (2006, p. 970), que destacaram:

\begin{abstract}
A opção adotada no decreto de prever, primeiro, que as Secretarias do MEC e o CNE determinarão as diretrizes para a elaboração de instrumentos de avaliação, tendo em vista o credenciamento, e, segundo, que é competência da Conaes estabelecer as diretrizes para a avaliação das IES e cursos, tem as seguintes dificuldades: a) as diretrizes podem ser contraditórias entre si; b) a diretrizes podem ter como pressuposto concepções distintas de educação superior; c) haverá duplicação de esforços governamentais para a realização de tarefas próximas.
\end{abstract}

Na prática, a tentativa de distinção da avaliação em dois processos, de fato, não se materializou. Entre os possíveis motivos para isso, pode-se sugerir a sobreposição de recursos financeiros e humanos para o desenvolvimento da avaliação do Sinaes para a emancipação em separado da avaliação para a regulação. Adicionalmente, ter-se-ia o risco de que dois processos separados entre si também pudessem oferecer resultados diferentes e, por isso mesmo, até divergentes, o que fragilizaria ambos.

Nesse ponto, cabe relembrar que os embates entre visões diferentes sobre o conhecimento organizado que dão sustentação às ações de governo interessam diretamente a este estudo, tendo em vista que tais embates podem materializar sentidos diferentes para a Política de Qualidade aqui referida. Assim, ao considerar a influência que os intelectuais exercem na formulação e na implementação de políticas públicas, procurou-se analisá-las considerando as noções de conhecimento e permeabilidade, numa tentativa de esclarecer as ideias que dão sustentação às ações públicas e seus desdobramentos.

Com base nessa perspectiva, analisou-se a publicação da Portaria Normativa MEC n. ${ }^{\circ}$ 40, de 12 de dezembro de 2007, que disciplinou a divisão de tarefas entre os atores responsáveis pelo Sinaes, redimensionando o "decreto ponte" (BRASIL, 2007d). Primeiramente, essa portaria reforçou em seu art. $1^{\circ}$, parágrafo $3^{\circ}$, o papel do Sinaes no subsídio à regulação, bem como ocupou o vácuo sobre a definição de quem seria a responsabilidade por realizar a regulação do sistema para fins de recredenciamento institucional e renovação de reconhecimento de cursos. Depois, detalhou as atividades a serem exercidas pelas Secretarias do MEC, CNE e Conaes, operacionalizando a distinção dos instrumentos e procedimentos avaliativos, em termos do ingresso em contraposição à permanência no sistema, mantendo-os unidos sob a perspectiva de subsídio à regulação. Ficou instituído que as Secretarias do MEC e o CNE estabeleceriam as diretrizes e aprovariam os instrumentos para os processos de avaliação do Sinaes com fins de credenciamento de instituições e autorizações e reconhecimentos de cursos, enquanto que a Conaes exerceria 
competência semelhante, mas para os casos de recredenciamento institucional e renovação de reconhecimento de cursos.

Com isso, a polarização de ideias em torno da função a que se destinam processos avaliativos de larga escala, como os do Enade, provocou um novo redirecionamento intelectual da sua proposta. A ponte que aparentemente distinguia o Sinaes do processo regulatório terminou por institucionalizar a ligação entre eles. A partir da portaria que organizou a operação do processo avaliativo do Sinaes (BRASIL, 2007d), houve uma "mudança de rumo" nos seus indicadores e procedimentos, que passaram a utilizar fortemente a vertente quantitativa e voltada para os resultados, com vistas a subsidiar o processo de regulação estatal.

O referido documento legal definiu três indicadores de qualidade, cada um representando um processo avaliativo pela agregação de um conjunto específico de variáveis para o seu cálculo: Conceito Preliminar de Curso (CPC) - para cursos, o Índice Geral de Cursos Avaliados da Instituição (IGC) - para instituições, e o Conceito Enade - para o desempenho discente, dividindo-se os alunos em ingressantes e concluintes. Com a adoção dos indicadores de qualidade pelo Sinaes, a aferição de indicadores, visualizada notadamente do ponto de vista qualitativo e organizada por meio de visitas a cursos e instituições, cedeu lugar à centralidade do desempenho dos estudantes, apurado por meio do Enade.

Aparentemente, a introdução dos indicadores de qualidade na estrutura do Sinaes distanciou o sistema avaliativo da sua proposta original, à medida que facilitou a promoção de rankings, a competitividade entre as instituições e o valor mercadológico proporcionado pela visibilidade dos resultados da avaliação da educação superior. Além disso, a forma como tais indicadores foram introduzidos dificultou a visualização do Sinaes como instrumento para o amadurecimento e a ampliação da autonomia das instituições de educação superior, tendo em vista que restringiu a realização das visitas para a avaliação de cursos. Com a substituição das visitas pelos indicadores de qualidade, houve uma redução na geração de relatórios detalhados sobre cursos e IES, os quais poderiam ser utilizados para análises qualitativas do desempenho de instituições e seus cursos. Sem esses relatórios, o Sinaes terminou por restringir informações detalhadas sobre cursos e IES que poderiam servir de bases para melhoria da qualidade da educação superior

Considerou-se, então, que as inovações trazidas pela referida portaria poderiam estar associadas à permeabilidade de uma visão que favorecia a libertação do Sinaes dos pilares da sua fundação - dissociação da regulação e do uso de indicadores quantitativos de resultado. Tal possibilidade foi sugerida por Dias Sobrinho (2008b, p. 820) quando asseverou que [...] 
[...] a primeira iniciativa [que interrompeu a construção do Sinaes como processo participativo e que promoveu o retorno a posturas, a axiomas e a enfoques próprios do paradigma técnico-burocrático] consistiu no desmonte da equipe que, com a experiência já demonstrada em mais de 15 anos de estudos e práticas no campo da avaliação da educação superior e com permanente apoio da comunidade universitária, vinha implantando o sistema de avaliação. Desmontada essa equipe, o Sinaes, ainda em processo de consolidar-se como cultura, pouco a pouco foi perdendo sua riqueza teórica e sua potencialidade ético-política e foi se reduzindo a ÍNDICES (não se trata de sigla para Índices Nacionais do Desempenho de Instituições e Cursos de Educação Superior).

Em uma espécie de síntese, Abreu Júnior (2009) destacou que, na perspectiva dos seus idealizadores, o Sinaes era considerado como integrador dos instrumentos de avaliação, articulando avaliação e regulação sem confundi-las, assumindo o compromisso de emancipar os agentes envolvidos. Entretanto, segundo esse autor, o que aconteceu após a portaria que regulamentou o "decreto ponte" (BRASIL, 2007d) foi a mesma priorização do desempenho discente que havia antes, em detrimento dos processos autoavaliativos que incorporassem as avaliações externas e favorecessem o processo de busca pela emancipação institucional com foco na qualidade.

Em meio aos embates travados no campo da avaliação da educação superior brasileira, depreendeu-se que as ideias e argumentos em um dado campo do saber, bem como as relações pessoais que se estabelecem entre aqueles interessados em sua implementação, influenciam as concepções e sentidos da ação do Estado no atendimento ao contexto político, social e econômico em que se encontra referenciado. Com isso, a discussão da questão da qualidade na formação de professores em nível superior evidenciou embates, seja do ponto de vista das diretrizes curriculares dos cursos de pedagogia - fundamentais ao Sinaes na estruturação de seus processos avaliativos -, seja do ponto de vista do próprio Sinaes, que pareceu não mais se encaixar na perspectiva emancipadora, que justificou a sua origem.

Concluída essa discussão sobre a existência (de fato) da Política de Qualidade, buscou-se no capítulo a seguir, analisar de forma mais apurada o próprio conceito de qualidade na educação superior, bem como suas interações com os conceitos de regulação e avaliação. Adicionalmente, procurou-se no desdobramento dos conceitos analisados, os indicadores e parâmetros que identificam um bom curso de formações de professores, em geral, e de pedagogia em particular. 



\section{QUALIDADE: DO CONCEITO AMORFO À DEFINIÇÃO DE CRITÉRIOS PARA OFERTA E AVALIAÇÃO DA LICENCIATURA EM PEDAGOGIA}

Neste capítulo, discutiu-se o conceito de qualidade a partir de construções teóricas realizadas no âmbito da produção e suas inserções no campo da educação superior. Em função da perspectiva de melhoria ou transformação positiva da realidade inerente a esse conceito, observou-se ainda sua relação com as concepções de avaliação e regulação da educação superior. Por fim, discutiram-se possíveis critérios de qualidade para avaliar e ofertar cursos de licenciatura em pedagogia, a partir de referências presentes em concepções acerca da formação de docentes, de orientações legais sobre a organização curricular do curso, bem como nas experiências internacionais sobre o tema.

\subsection{APROXIMAÇÕES AO CONCEITO DE QUALIDADE}

Em contexto de acumulação flexível, ${ }^{35}$ referências à qualidade para a produção de bens e serviços foram localizadas nos manuais voltados à gestão de organizações empresariais, sendo bastante estudadas nas áreas das ciências administrativa e econômica. Por isso, partiu-se do entendimento de que observar a noção de qualidade a partir dessas áreas possibilitaria o olhar mais amplo sobre a definição, o tratamento e a utilização desse conceito na educação superior, mesmo assumindo que o processo ensino-aprendizagem não pode ser classificado como uma mercadoria nem o aluno como um consumidor.

Essa reflexão sobre a transição do conceito de qualidade do campo da produção para o da educação foi proposta por Silva (2009), que argumentou ser tal análise possível tendo em vista o social estar imbricado com o econômico, além de ambos se configurarem como partes de um todo, inseridos em espaços e tempos históricos determinados. Porém, a autora alertou que essa transposição não poderia ser direta, como se a lógica da compra e escolha dos consumidores pudesse ser adotada no campo educativo, pois levaria a uma descaracterização da educação como um direito garantido socialmente pelas democracias. Assim, com base nesse alerta, analisou-se a questão da qualidade na educação superior brasileira, notadamente aquela relativa à oferta dos cursos de pedagogia do Parfor, fazendo-se a ligação entre o conceito utilizado na esfera da produção capitalista e suas repercussões e possibilidades de entendimento no campo educacional.

\footnotetext{
${ }^{35}$ De acordo com Harvey (1992), pode ser entendido como padrão capitalista de produção baseado em processos mais flexíveis (diversidade de produtos, de contratação de pessoal, inovação constante etc.), inserido em mercados globais e de competição acirrada.
} 
Numa rápida síntese teórico-histórica sobre a evolução das discussões sobre qualidade nas ciências sociais aplicadas, destacaram-se as contribuições de W. Edwards Deming, pioneiro no estudo da qualidade no campo da produção, que, na década de 1940, associou o termo a aspectos de uniformidade e confiabilidade de um produto às suas especificações técnicas, definidas previamente por engenheiros e gerentes responsáveis pela sua criação e fabricação. Na década seguinte, Joseph Juran ampliou essa definição de qualidade, deslocando-a da perspectiva meramente técnica para abranger também a adequação do produto à sua utilização pelo consumidor. Com isso, Juran abriu uma importante fronteira para o estudo da qualidade, que deixou de ser entendida apenas do ponto de vista estático (técnico), passando a incorporar a dinamicidade da sociedade trazida pelo consumidor, bem como fazendo emergir a necessidade de um processo para sua gestão em função das crescentes demandas por inovação. Finalmente, na década de 1980, David Garvin propôs como inovação ao léxico da qualidade a perspectiva de dimensões ou faces, evidenciando o caráter polissêmico do conceito (GOMES, 2004).

Dessa síntese histórica, destacou-se que a perspectiva de dinamicidade do conceito em foco, sugerida por Juran (1999), trouxe embutida a necessidade de racionalização do processo por meio do qual se procura atender às demandas do consumidor por novas adequações dos produtos e serviço. Como tais demandas são constantes, elas terminam por promover um permanente processo de mudança naquilo que se entende por qualidade. Nesse sentido, Juran (1999) propôs realizar os ajustes na definição do que é qualidade por meio da sua gestão, baseada na trilogia planejamento-controle-melhoria. Segundo o autor, o planejamento estabelece objetivos, metas da qualidade e os caminhos para alcançá-los; o controle compara a realidade com os objetivos definidos, permitindo corrigir as diferenças; e a melhoria evolui os objetivos da qualidade, garantindo uma constante revisão do planejamento para fechar o ciclo da renovação periódica e racionalizada daquilo que foi definido como qualidade. Essa perspectiva de gestão da qualidade, sugere uma permanente alteração da definição do conceito, podendo ainda ser visualizada por meio das dimensões propostas por Garvin (1987), que (re)definem aquilo considerado bom ou adequado na oferta de um produto ou serviço, conforme (re)arranjo das partes e do todo.

A partir desse entendimento multifacetado do conceito de qualidade trazido por Garvin (1987) e tomando-se como referência as contribuições de Juran (1999), sintetizou-se inicialmente o conceito em foco no campo da produção por meio de duas dimensões básicas, a saber: técnica, definindo-se a qualidade de produtos e serviços a partir de especificações objetivas como rentabilidade, características de funcionamento, tempos diversos, número de 
defeitos, etc.; e prática ou social, definindo-se essa qualidade a partir da satisfação das necessidades e expectativas dos indivíduos.

Apesar de as dimensões técnica e social parecerem opostas, elas se encaixaram de forma complementar: pode-se até fazer a opção por uma em detrimento da outra, mas não foram encontrados argumentos que indicassem que elas se anulam mutuamente ou não podem estar presentes em uma mesma realidade. Reforçou esse entendimento a contribuição de Werkema (1995) que definiu qualidade associando-a às características dos produtos ou serviços capazes de promover satisfação pela ausência de defeitos (técnica) e pela presença de elementos que agradem ao usuário (social).

A perspectiva de vários significados para o termo qualidade se mostrou bastante difundida nas análises e estudos sobre o termo no campo da produção. Para Gomes (2004, p. 7), "a qualidade é considerada universalmente como algo que afeta a vida das organizações e a vida de cada um de nós de forma positiva [...] No entanto, nem sempre partimos de uma definição clara do que é a qualidade”. Do ponto de vista dos consumidores, podem existir diversas concepções sobre o que faz um produto ou serviço possuir qualidade, ou, ainda, tais concepções podem ser difusas e não declaradas. No entanto, se reconheceu que em um contexto de competição capitalista, empresas e governos necessitam demonstrar transparência nas regras que sustentam a comparação de bens e serviços. Com isso passou a ser cada vez mais comum a exigência de definições expressas sobre qual é, entre várias configurações para os produtos comercializados, aquela que contempla características identificadas como técnica e socialmente adequadas. ${ }^{36}$

Tendo como referência esse entendimento, fez-se a distinção entre o termo "qualidade" daquilo que se denominou "critério de qualidade". A qualidade, nesse caso, foi associada a um sentido genérico e inespecífico, envolvido por uma áurea etérea, difusa, aparentemente compartilhada por todos sobre o que é adequado, mas que pode levar a caminhos e objetivos diferentes. Em contrapartida, os critérios foram apropriados como aquilo que especifica e referencia um objeto a determinado parâmetro, dando significado real à qualidade (operacionalizando o conceito).

\footnotetext{
${ }^{36} \mathrm{Na}$ área produtiva, existem diversas possibilidades de padrões de qualidade, como aqueles de certificação em nível internacional, como o International Organization for Standardization (ISO) e o International Eletrotechnical Comission (IEC); regionais, como a Comissão Panamericana de Normas Técnicas (COPANT) e a Associação Mercosul de Normalização (AMN); ou nacionais, como a Associação Brasileira de Normas Técnicas (ABNT) e o Instituto Nacional de Metrologia, Qualidade e Tecnologia (Inmetro). Cada uma dessas certificações de qualidade adota indicadores de mensuração e parâmetros de julgamentos diferenciados, aos quais as empresas se associam, ou não, conforme imposição legal ou adequação às suas estratégias e interesses corporativos.
} 
No campo da educação, admitindo a diversidade e mutabilidade da definição de qualidade, Sousa (2009) chamou a atenção para o fator transformação como essencial à compreensão contextualizada e crítica do percurso histórico e social da construção do conceito. Embora o autor tenha reconhecido que, etimologicamente, qualidade pode ser definida como um atributo capaz de distinguir, marcar, determinar a natureza de dado objeto, considerou que não se pode atribuir um valor absoluto à qualidade no campo educacional, tampouco à mera adequação de ideias, processos e práticas a padrões e normas estabelecidas previamente, tendo em vista o contexto histórico, econômico e social em que se desenvolve.

Dentro dessa perspectiva polissêmica e aparentemente inspirada nas dimensões de qualidade proposta por Garvin (1987), Harvey e Green (1993) apontaram cinco possibilidades ou faces para a definição do conceito na educação superior, a saber:

a) qualidade como fenômeno excepcional: associada às noções de exclusividade e elitismo; à noção de excelência, superando os padrões estabelecidos; e à satisfação ou conformidade a um conjunto de requisitos periodicamente apurados.

b) qualidade como perfeição ou coerência: associada à perspectiva que as especificações devem ser exatamente cumpridas, contrapondo-se à abordagem de qualidade como fenômeno excepcional.

c) qualidade como ajuste a um propósito: associada à noção de conformidade com o propósito ou finalidade para o qual o objeto foi criado.

d) qualidade como relação custo-benefício: associada à perspectiva de prestação de contas dos recursos públicos investidos ao público diretamente interessado no resultado apresentado.

e) qualidade como transformação: associada à noção de transformação e mudança para melhor, seja do aluno, seja do professor, seja do curso, seja da instituição.

A visão da qualidade por meio de dimensões também foi apropriada por Morosini (2001), que associou o conceito na educação superior às noções de isomorfismo, diversidade e equidade. Nessa abordagem, isomorfismo refere-se à adequação da educação superior a um dado nível de desempenho padronizado; diversidade, à perspectiva de respeito às diferenças regionais, culturais e econômicas das IES e seus cursos; e equidade, à incorporação de indicadores qualitativos e quantitativos referenciados na realidade institucional. Para a autora, tais aspectos se configuram como aproximações a uma noção de qualidade, alertando que, na prática, existe uma combinação entre eles. Adicionalmente, revisitando essas dimensões, Morosini (2009) reconheceu que o contexto sócio-histórico vem provocando uma minimização das suas fronteiras, sugerindo a possibilidade de tomar essas dimensões separadas como um todo concreto. 
Assumindo outras categorias para discutir o conceito de qualidade na educação superior, Dias Sobrinho (2008a) visualizou esse conceito com base em duas dimensões polarizadas. A primeira, da qualidade sob o ponto de vista social, que valoriza aspectos que permitem a formação ética e o desenvolvimento intelectual dos indivíduos, entendendo a educação como um bem público. A segunda, da qualidade associada ao mercado, considerando a educação como mercadoria pela valorização de aspectos que permitem o desenvolvimento de competências para o trabalho, credenciando os indivíduos ao emprego, e pela comparação ou ranqueamento em torno daquilo que foi aprendido particularmente. Apesar de essas dimensões terem sido colocadas de forma contrapostas, Dias Sobrinho (2008a) não negou que a separação ou purismo desses sentidos do termo qualidade seja apenas conceitual, deixando entrever a possibilidade de outros tipos de relação dialética entre as faces da qualidade na educação superior discutidas por ele.

No entendimento de Dourado e Oliveira (2009, p. 203), "qualidade é um conceito histórico, que se altera no tempo e no espaço, ou seja, o alcance do referido conceito vinculase às demandas e exigências sociais de um dado processo histórico". Essa assertiva reforçou o entendimento apresentado por Sousa (2009) de adaptação do significado de qualidade na educação superior às condições empíricas nas quais está inserido. Na mesma linha, Rios (2010, p. 64) afirmou que na educação [...]

[...] o conceito de qualidade é totalizante, abrangente, multidimensional. É social e historicamente determinado porque emerge de uma realidade específica e de um contexto concreto. Portanto, uma análise crítica da qualidade deverá considerar todos esses aspectos, articulando aqueles de ordem técnica e pedagógica aos de caráter político-ideológico.

Assim, considerando a perspectiva contextualizada da qualidade, há um quase consenso no campo educacional sobre a polissemia do termo, decorrente tanto da subjetividade na apropriação de critérios ou aspectos que o define (marcadamente condicionados a contextos históricos, econômicos, sociais e políticos específicos) quanto da infinidade de situações distintas nas quais ele pode ser aplicado, entre outros, a curso, instituição, docentes, processo ensino-aprendizagem, etc. (BERTOLIN, 2007; BURLAMAQUI, 2008; DIAS SOBRINHO, 2008b; DOURADO; OLIVEIRA, 2009; FONSECA, 2009; HORTALE; MOREIRA; KOIFMAN, 2004; MOROSINI, 2001; RIOS, 2010; SILVA, 2009; SOUSA, 2009).

Com isso, o conceito de qualidade na educação superior aparentemente vem assumindo diversas conotações a cada momento histórico, seguindo tendência também 
pontuada por Juran (1999) no campo da produção de bens e serviços. No que se referiu especificamente às possibilidades ou caminhos para se chegar à oferta de um curso de formação de professores com qualidade, considerou-se adicionalmente que a sua modificação ao longo do tempo dependeria dos embates dos grupos de interesse que colaboram em torno da definição de seus critérios, dando forma e sentido ao seu significado. Em síntese, diante das várias possibilidades para a definição da qualidade, entendeu-se que sua significação emergiria dos interesses daqueles diretamente afetados por ela, alterando-se ao longo do tempo, conforme a reconfiguração desses mesmos interesses.

A partir desse raciocínio, assumiu-se o conceito de qualidade no campo da educação superior brasileira não como polissêmico, mas, sim, amorfo, uma vez que não são todos os seus possíveis sentidos que são válidos ao mesmo tempo, mas apenas um deles. A revisão até aqui empreendida, associada ao contexto do Sistema Nacional de Ensino Superior, levou à proposição de que o conteúdo concreto do que é qualidade pode alterar-se em várias direções conforme o momento histórico, mas é passível de individualização. No contexto em questão, observou-se que o termo "qualidade" sintetizou apenas um dado conjunto das suas possíveis faces ou dimensões para a oferta de cursos, aferição de sua conformidade ou ação corretiva, sendo inclusive o objeto de questionamento visando a sua superação por outro padrão do que é bom ou adequado para cursos/IES.

Ilustrando esse entendimento, na década de 1990, a qualidade dos cursos de graduação no Brasil esteve associada à dimensão do desempenho de alunos egressos, aferido por meio de exames nacionais, de acordo com cada área de formação. Na década de 2000, ampliou-se essa concepção, incluindo-se dimensões como infraestrutura, corpo docente e organização didático-pedagógica. Já no caso da avaliação dos programas de pós-graduação, o conteúdo do que se considerou qualidade ao longo do tempo migrou de uma perspectiva centrada na titulação docente e no tempo médio de titulação dos alunos, passando por uma visão centrada na produção acadêmica dos cursos, até chegar, mais recentemente, à inserção internacional dessa produção. Nesses exemplos, observou-se que determinado conjunto de dimensões ou faces do conceito de qualidade imprimiu-lhe significado a cada momento. Então, preferiu-se considerar nesta pesquisa qualidade como conceito amorfo (que se altera conforme o recheio do seu significado), e não polissêmico, que remete à validade de todos os significados ao mesmo tempo.

A partir desse entendimento, buscou-se identificar as faces/dimensões específicas que imprimem significado para o que é a qualidade de curso formação de professores para a educação infantil e anos iniciais do ensino fundamental no contexto da Política de Qualidade 
delineada. Para tanto, optou-se por discutir o termo qualidade por meio de seu conteúdo específico, ainda que se tenha reconhecido a dificuldade em se lidar com um constructo que, por não ter forma previamente definida, pode ser preenchido por uma infinidade de recheios, um dos quais vão emprestar-lhe uma identidade dentro de um dado quadro histórico-social. Por isso mesmo, a dimensão política da construção dessa identidade ou significado precisou ser contemplada.

A ideia de que o significado do que se entende por qualidade na educação superior é construído politicamente foi assumida por Harvey e Williams (2010). Na mesma linha de argumentação, Bertolin (2007) asseverou que concepções de qualidade estão relacionadas a uma perspectiva subjetiva de quem as emite, dando sentido ao conceito a partir de um ponto de vista. Também Burlamaqui (2008) pontuou que diferentes grupos de interesses promovem percepções distintas sobre a qualidade nesse campo. Destacou, ainda, a multifuncionalidade e a complexidade do conceito, que pode contemplar na educação superior as atividades de ensino, pesquisa, extensão, estruturas físicas, ambiente acadêmico, etc., bem como dicotomias entre qualitativo/quantitativo, produtos/processos e eficácia/eficiência. Tendo como referência esses autores, apropriou-se, nesta pesquisa, da assertiva de que preferências, crenças, valores e até mesmo afinidades e interesses pessoais ou coletivos permeiam a definição de qualidade na educação superior.

Adicionalmente, encontrou-se em Fonseca (2009) a discussão de que os embates oriundos dos movimentos sociais e as ações dos diversos governos federais brasileiros, que se sucederam desde o início do período militar até o final dos anos 2000, produziram diferentes significados para a qualidade em educação no Brasil. Na perspectiva da autora, tais significados oscilaram entre parâmetros que privilegiaram a emancipação dos sujeitos e a formação do cidadão, e aqueles voltados à preparação dos indivíduos para a produção e o consumo.

Reforçando a dimensão política do conceito de qualidade, bem como a sua relação direta com os critérios que o sustenta, Cabrito (2009) entendeu que as discussões em torno da qualidade da educação têm levado em conta um padrão de referência definido sob a perspectiva do Estado neoliberal, fomentando a concorrência, a rivalidade e a discriminação, em claro processo de reprodução das exclusões e das desigualdades sociais. Nesse sentido, assumindo que tal padrão no campo educativo é subjetivo, o autor terminou por desconsiderar a validade dos critérios de qualidade escolhidos sob a perspectiva neoliberal/capitalista. Desconsiderou também os processos avaliativos decorrentes desses critérios, uma vez que permitiam comparar instituições entre si, reproduzindo "as diferenças e as assimetrias entre 
governantes e governados, entre ricos e pobres, entre burgueses e operários, de forma intencional"' (CABRITO, 2009, p. 197).

Por outro lado, Cabrito (2009) resgatou a validade da discussão sobre qualidade em educação, desde que fossem observados dois aspectos: a) indicadores de natureza quantitativa e qualitativa, que mesmo não sendo padronizados, representem necessariamente toda a realidade que se pretende avaliar; b) indicadores que resultem na impossibilidade de comparação entre as instituições, evitando que se promova a competição. Interessante também notar que, para o autor, a seleção de determinados critérios (voltados aos interesses capitalistas) tornaria a própria discussão de qualidade como não aceitável. Em contrapartida, se os critérios selecionados fossem outros (aqueles sugeridos pelo autor e fundados em uma postura mais socializante), então a discussão da qualidade na educação superior seria válida. Corroborando a perspectiva de embates em torno da definição de qualidade, aparentemente, na opinião de Cabrito (2009), o norte que faz o ponteiro de sua bússola girar entre um polo e outro da validade da discussão sobre qualidade na educação superior estaria na seleção dos critérios usados para medir tal qualidade: se favoráveis a interesses burgueses ou proletários, conforme explicitado por ele.

Essa discussão sobre qualidade na educação superior permitiu evidenciar, então, uma terceira dimensão do conceito de qualidade: a política, que complementou as duas primeiras já destacadas (dimensões técnica e social). As contribuições até aqui revisadas em torno dessa terceira dimensão sugeriram que ela legitima e promove a adesão ou filiação em torno do que é considerado bom ou adequado técnica e socialmente. Além disso, a face política do conceito de qualidade reforçou o entendimento de que o significado do termo só perde o seu sentido genérico, quando apropriado por meio de uma especificação clara do que representa.

Em termos operacionais, o conteúdo específico que dá forma/identidade ou significado ao conceito foi traduzido nesta pesquisa como critérios de qualidade. Esses critérios foram visualizados como produto de disputas permanentes entre diversos grupos de interesses afetados pelo significado e consequentes usos da qualidade na educação superior. Considerouse, ainda, que tal significado de qualidade não se esgotaria em si mesmo, uma vez que, como produto de disputa, seria passível de alteração sempre que perdesse legitimidade (entendida como a força de uma ideia em relação a outras e não a partir de um consenso em torno dela).

Por outro lado, mesmo assumindo a centralidade dos critérios para o significado daquilo que se entende por qualidade na educação superior, reconheceu-se que outros elementos, notadamente aqueles que envolvem os conceitos de avaliação e regulação, aparecerem na literatura como diretamente imbricados nesse significado. Dessa forma, 
buscou-se, na seção que segue, adentrar ainda mais nessa discussão, analisando de que forma os elementos citados organizam o conceito em foco no contexto da Política de Qualidade.

\subsubsection{Critérios como aspecto central na definição de qualidade}

A literatura consultada nesta pesquisa sobre qualidade na educação superior destacou esse conceito na realidade de cursos e IES por meio de processos avaliativos, regulatórios e, consequentemente, de indicadores e parâmetros utilizados na estruturação desses processos. Ilustrando essa tendência, Harvey e Williams (2010) identificaram que grande parte dos artigos publicados nos 15 anos de vida de um respeitado periódico internacional, ${ }^{37}$ especializado no tema da qualidade da educação superior, tratou majoritariamente de temas afetos aos processos avaliativos em universidades ou à regulação exercida por sistemas nacionais dos principais países dos cinco continentes. Com menor frequência, os autores também identificaram artigos que discutiram mais especificamente indicadores e parâmetros de qualidade, bem como abordaram qualidade de forma teórica, evidenciando dimensões que lhe dessem significado.

Considerando esse quadro, buscou-se entender melhor como avaliação, regulação, indicadores e parâmetros de qualidade se relacionam ao conceito de qualidade em si, no contexto da educação superior brasileira. Para tanto, assumiu-se a experiência da avaliação da pós-graduação como ponto de partida, uma vez que ela se configurou como o mais consolidado processo de garantia da qualidade do nível educacional em estudo, oferecendo alguns subsídios empíricos para a discussão teórica dos conceitos destacados no âmbito desta pesquisa.

A prática da Avaliação da Capes destacou um instrumento avaliativo isomórfico similar ao utilizado pelo Sinaes para as avaliações in loco - denominado Ficha de Avaliação. Esse instrumento é composto por itens avaliativos parametrizados em torno de uma escala de valores que vão de um a cinco (associados, respectivamente, aos conceitos fraco, deficiente, regular, bom, muito bom). ${ }^{38}$ Porém, diferentemente do que vem ocorrendo no Sinaes, o instrumento avaliativo da pós-graduação não é único, apesar de guardar uma estrutura semelhante em termos dos quesitos/dimensões avaliados. Ele é capaz de hierarquizar

\footnotetext{
37 Quality in Higher Education (London), classificado pela Comissão de Área de Educação no Sistema Qualis/Capes como A1.

38 A escala de medidas vai de um a sete. Os níveis seis e sete são indicativos de inserção internacional do Programa.
} 
programas de pós-graduação ${ }^{39}$ de determinada natureza e área de conhecimento. As fichas seguem itens específicos conforme as características dos programas, a saber: a) natureza acadêmica ou profissional; b) áreas de conhecimento; c) pertencimento, ou não, ao Sistema Nacional de Pós-Graduação (SNPG) - proposta de curso ou curso em funcionamento; e d) tempo de permanência no SNPG - curso novo ou curso consolidado. Consequentemente, o processo de preenchimento das fichas avaliativas seguem critérios de qualidade individualizados, conforme enquadramento do programa. Assim, mesmo possuindo uma função padronizadora da qualidade dos cursos de mestrado e doutorado no país, os critérios de qualidade utilizados nesse processo avaliativo tendem a respeitar diferenças nos propósito dos cursos de pós-graduação, sua maturidade, bem como as especificidades das áreas de conhecimento às quais pertencem. Tais critérios vêm sendo documentados e divulgados pelas diversas áreas de avaliação, ${ }^{40}$ e, apesar de mais recentemente os parâmetros de preenchimento das fichas avaliativas não estarem fazendo parte de forma explícita do documento, têm sido capazes de fornecer um significado do que se entende como bom e adequado para um programa de pós-graduação acadêmico e profissional, quando novo e quando consolidado em determinada área de conhecimento, operacionalizando uma concepção de qualidade. No entanto, os padrões de qualidade estabelecidos pela Capes não são assumidos acriticamente pelos atores envolvidos. Tais padrões costumam ser questionados no decurso e no final do processo avaliativo, transformando-se em elemento de disputa entre grupos e estando em permanente processo de adaptação.

Os interesses em torno do padrão de qualidade da pós-graduação costumam movimentar-se em função de ocorrências regulatórias viabilizadas pelos resultados avaliativos, a saber: i) ações de exclusão ou inclusão de cursos de mestrado ou doutorado no sistema; ii) processos de fomento aos programas por meio de ações construídas para atender às suas necessidades, conforme perfil identificado no processo avaliativo; iii) ações locais que confrontam interesses intrauniversidade, ao seguir orientações contidas nas Fichas de Avaliação; iv) sinalizações de inovações consideradas necessárias ao sistema, tanto em nível central quanto local; e v) demandas locais por ajustes nos próprios critérios avaliativos.

\footnotetext{
${ }^{39}$ Unidade avaliativa utilizada pela Capes, podendo corresponder a um curso de mestrado profissional, mestrado acadêmico ou doutorado, bem como ao conjunto formado pelos cursos de mestrado acadêmico e doutorado que compartilhem a mesma organização pedagógica, corpo docente e infraestrutura.

${ }^{40}$ Unidade operacional utilizada pela Capes para agregar áreas de conhecimento afins, permitindo aplicar um conjunto de regras próprias aos programas de pós-graduação que tratam de temas próximos ou semelhantes. Assim, nem toda área de conhecimento se constitui em uma área de avaliação. Além disso, algumas áreas de conhecimento podem se dividir em mais de uma área de avaliação, conforme os interesses envolvidos.
} 
Com isso, entendeu-se que, nesse contexto, o processo avaliativo emergiu como responsável por descrever e valorar a realidade da pós-graduação, com base em critérios documentados, fornecendo subsídios ao processo regulatório. Nesse sentido, pôde-se vislumbrar uma relação de complementaridade entre avaliação e regulação, justamente por meio dos desdobramentos viabilizados pelo uso de critérios de qualidade. Para fundamentar a construção desse entendimento, apoiou-se inicialmente em Bertolin (2007), que definiu a avaliação como $[\ldots]$

[...] um processo sistemático que envolve coleta de dados, análise de informações e juízo de valor e mérito acerca da qualidade do sistema de educação superior. Dessa forma, tal processo deve contemplar etapas de definição de sistemas de indicadores, a valoração e monitoração dos indicadores, a análise e estudo dos resultados e a emissão de juízo de valor e mérito (BERTOLIN, 2007, p. 258).

Nessa abordagem, os critérios puderam ser entendidos como parte do processo avaliativo, definindo e parametrizando indicadores. Esse autor esclareceu, ainda, que são os indicadores, ao traduzir a realidade de uma forma mensurável, que permitem aferi-la e julgála. Nesse sentido, os critérios de qualidade foram apropriados nesta análise como o conjunto de indicadores e parâmetros que instrumentalizam o processo de identificação e valoração da realidade, em termos de sua qualidade.

Ainda do ponto de vista da relação entre critérios de qualidade e avaliação, encontrouse em Neder (1996, p. 75) o entendimento de que "a avaliação, como prática educativa, deve ser compreendida sempre como uma atividade política, cuja principal função é a de propiciar subsídios para tomadas de decisões quanto ao direcionamento das ações em determinado contexto educacional”. Dessa definição de avaliação emergiram dois aspectos intimamente imbricados com a definição de qualidade que vem sendo delineada neste trabalho: o político e o de ação/decisão. Do ponto de vista político, depreendeu-se que o processo avaliativo contemplaria a mediação de interesses, dos valores e da visão de mundo daqueles afetados por seus resultados, sintetizando embates em torno da definição dos critérios de qualidade que lhes dão sustentação. No que se referiu ao binômio ação/decisão, considerou-se que os resultados avaliativos aferidos por meio dos critérios de qualidade ofereceriam os subsídios necessários à tomada de decisão e ao direcionamento de ações sobre a realidade avaliada.

Sem adentrar na questão política, Dutra (1984) corroborou a perspectiva de ação/decisão em torno do conceito de avaliação discutido por Neder (1996), ao ponderar que embora a determinação de um valor seja a conotação mais aceita para o referido conceito, a avaliação também se relaciona às atividades de conhecer, decidir e agir. Com isso, reforçou- 
se o entendimento de que o processo avaliativo não se limitaria apenas a um julgamento sobre a realidade com base em critérios de qualidade politicamente legitimados. Esse julgamento também precisaria estar vinculado a algum propósito ou objetivo.

Para sistematizar tal proposição, analisou-se o conceito de avaliação a partir das três dimensões delineadas pelas contribuições dos autores até aqui consultados: diagnóstico, julgamento e subsídio à ação. Com base neles, entendeu-se que na dimensão informação são medidos os atributos do objeto avaliado. No julgamento, emite-se um juízo de valor comparando-se a extensão do atributo medido ao padrão determinado politicamente entre aqueles interessados no seu resultado. Já na ação prepara-se o caminho tanto para corrigir como ratificar os aspectos medidos em relação ao padrão definido de julgamento, cabendo, inclusive, alterações ou ratificações dos próprios padrões (meta-avaliação).

Ressaltou-se, no entanto, que o subsídio à ação, associada ao conceito de avaliação, não pareceu confundir-se com a ação propriamente dita. O raciocínio desenvolvido nesta análise levou à compreensão de que a função da avaliação vincula-se à sustentação de decisões, e não diretamente a sua execução. Inclusive, no contexto da educação superior brasileira, os atores envolvidos no processo avaliativo não têm sido os mesmos responsáveis pelas ações/decisões apontadas por seus resultados. Adicionalmente, a avaliação e a regulação têm seguido uma tendência de tempos não conectados, a ponto de ser possível não existir qualquer ação como consequência de resultados avaliativos. Exemplos dessa separação entre a avaliação e a ação que ela pode subsidiar puderam ser encontrados nos seguintes fatos concretos: i) os procedimentos de inclusão/exclusão/manutenção de cursos de mestrado ou doutorado no SNPG, bem como a distribuição de recursos de fomento a eles, são realizados após o encerramento do processo avaliativo e ficam sob a responsabilidade de atores diferentes dos que se responsabilizam pela realização da avaliação; ii) não foram encontrados registro de cursos fechados em função de resultados insatisfatórios, aferidos pela experiência do "Provão"; e iii) o Sinaes separa a avaliação da ação tomada com base nela por meio do que o "decreto ponte" denomina de regulação.

Além disso, as fronteiras estabelecidas pelo Sinaes entre a avaliação e a regulação foram permeadas pela polarização entre duas visões do processo avaliativo: a que emancipa (avaliação) e a que controla (regulação), conforme discutido na subseção 1.4.3. Porém, tal polarização não explicou adequadamente a relação entre esses dois conceitos no âmbito desta pesquisa. As construções teórico-empíricas aqui desenvolvidas apontaram para a perspectiva de que avaliação e regulação se configuram como processos diferentes, e não dois polos distintos de um mesmo processo. Por outro lado, mesmo que fossem considerados como polos 
ou funções do processo avaliativo, considerou-se que esses dois conceitos funcionariam melhor juntos do que separados, seguindo movimento similar ao entendimento dos conceitos de avaliação somativa e formativa, apresentados por Scriven (1967).

$\mathrm{Na}$ avaliação somativa, emite-se um juízo de valor terminal sobre as informações que representam a realidade de um dado momento. Metaforicamente, pode ser visualizada como uma fotografia que permite comparações e ranqueamento entre instituições com base em indicadores que retratam uma realidade estática. Com isso, parece favorecer o controle, seja punindo pelo não alcance de determinada meta de qualidade (como redução de verbas ou perda de alunos), seja premiando (com a oferta de bônus e benefícios) se a meta for alcançada.

Quando se tem uma perspectiva de melhoria e adequação do sistema, ganha relevância a avaliação formativa, que tem por base a ideia de construção de uma nova realidade. Sob sua égide, seria possível ampliar as possibilidades e transformar "o ruim" em oportunidade de crescimento, e "o bom" em melhoria, ampliação e evolução. $\mathrm{O}$ foco aqui se deslocaria, então, de uma função terminal da avaliação, por meio de uma nota ou conceito, para o diagnóstico proporcionado pelo processo avaliativo, subsidiando a transformação da qualidade então apurada.

Apresentada dessa forma, a avaliação somativa ficou mais diretamente associada ao que Barretto (2001) e Meneghel, Robl e Silva (2006) chamaram de dimensão reguladora da avaliação, enquanto a avaliação formativa pôde ser mais prontamente relacionada à dimensão emancipatória, também discutida pelas autoras citadas. Considerando essa associação, entendeu-se que tanto a perspectiva formativa quanto a somativa poderiam ser necessárias ao Sistema Federal de Ensino Superior. Esse entendimento foi elaborado a partir da complementaridade dialética, procedimento operatório previsto no hiperempirismo dialético, que permitiu apropriar a avaliação formativa como articulada à somativa (e vice-versa) - e não separadas. Nessa perspectiva, entendeu-se que ambas partilham de utilidade igualmente importante, necessária e desejável ao processo de avaliação, inclusive no subsídio à punição/premiação tão criticada na literatura especializada.

O contraponto que se lançou nesse raciocínio foi o das motivações humanas para mudança. $\mathrm{Ou}$, numa perspectiva institucional, sobre os motivos que justificariam a busca por alterar sua realidade, considerando as forças de inércia e resistência inerentes a qualquer processo de modificação da realidade, conforme discutido por Strebel (1993). Seguindo esse raciocínio, o resultado somativo poderia servir como força impulsionadora de transformações necessárias, contrabalançando as resistências naturais a elas. A partir dessa visão, uma 
perspectiva de qualidade formativa necessitaria de um componente somativo para ser deslanchada; ou, na direção contrária, uma face somativa de qualidade pouco repercutiria na evolução do sistema se abandonasse o componente formativo na sua ação.

Adicionalmente, no contexto desta pesquisa, entendeu-se que processos avaliativos não precisariam ser visualizados apenas como formativos, tampouco os processo regulatórios deveriam ser visto apenas como somativos ou voltados ao controle. Assumindo a perspectiva de que os critérios de qualidade instrumentalizam a avaliação e, por consequência a regulação, esses dois processos poderiam assumir naturezas igualmente somativas e formativas, conforme sentido viabilizado pelos critérios.

Para justificar esse entendimento, recorreu-se a Barroso $(2005,2006)$, para quem o conceito regulação envolve mais do que a simples tentativa de reprodução de regras impostas. $\mathrm{O}$ autor ressaltou que regulação não se confunde com a perspectiva de regulamentação. Apesar de outros autores, como Dias Sobrinho (2003), associarem regulação ao controle exercido externamente pelo Estado sobre as IES, Barroso $(2005,2006)$ defendeu que é a regulamentação, e não a regulação, que parte de processos previamente definidos, tendo como parâmetro uma forma prevista/engessada de se fazer as coisas, independentemente da possibilidade de alcançar de resultados melhores por meio de processos alternativos. Por outro lado, o autor reconheceu a existência de uma diversidade de possíveis entendimentos sobre o que significa regulação, quais sejam:

a) regulação por meio de regras - que se aproxima da definição de regulamentação, na qual se estabelecem regras a partir das quais se operacionalizariam objetivos. Nessa perspectiva, são as regras que devem ser seguidas, assumindo-se que ao cumpri-las os objetivos também seriam alcançados;

b) regulação como controle de elementos autônomos - identificada como interferência de instâncias estatais, orientando e coordenando a ação dos diversos agentes;

c) regulação conservadora - com função de assegurar o equilíbrio e o partilhamento igualitário do sistema;

d) regulação transformadora - com a tripla função de compreender: como um sistema dá lugar a novas formas de organização; como um processo de regulação dá origem ao seu sucessor; e que interdependência se estabelece entre diferentes modos de regulação;

e) regulação institucional, normativa e de controle - entendida como o conjunto de ações decididas e executadas por uma instância central para orientar os demais atores e suas interações; 
f) regulação situacional, ativa e autônoma - definição de regras que orientam o funcionamento do sistema, como também o seu (re)ajustamento provocado pela diversidade de estratégias e ações dos vários atores; e

g) regulação conjunta - referindo-se à interação entre a regulação de controle e autônoma para ordenamento do sistema social.

A partir dessas concepções e adotando uma abordagem interpretativa - compartilhada nesta pesquisa - Barroso $(2005,2006)$ entendeu que regulação é um processo inerente a qualquer sistema, tendo como função assegurar-lhe equilíbrio, coerência e transformação, por meio de regras e adequação dos seus elementos nos níveis micro, meso e macro. Com isso, do ponto de vista dos cursos de formação de professores, associou-se a microrregulação às ações desenvolvidas no âmbito local (IES, município, escola, etc.). Tais ações resultariam da interação dos diversos atores locais (gestores, professores, alunos, comunidade, etc.), podendo ocorrer numa perspectiva vertical (hierarquizada) ou horizontal (participativa). Já o nível meso pôde ser vinculado à regulação nacional, configurada pelas ações exercidas por autoridades de âmbito nacional ou regional para coordenar, controlar e influenciar o sistema educativo de acordo com suas orientações. No que concerniu à regulação em nível macro, esta foi visualizada na perspectiva transnacional por meio de ideias contidas em discursos, documentos e orientações voltadas à educação que circulam entre as comunidades epistêmicas e organismos multilaterais. Tais ideias influenciariam direta ou inversamente as ações dos gestores e atores nacionais e locais, conforme afiliação deles a elas, seja no sentido de baixo para cima (regulação local), seja de cima para baixo (regulação nacional).

A partir desse raciocínio, a regulação do sistema educativo não se apresentaria, então, de forma linear, mas, sim, em vários sentidos entre os diversos atores. Com isso, terminaria por se configurar mais em uma espécie de regulação da regulação, do que na aplicação de regras do regulador em relação ao regulado. Nesse processo, conforme explicitou Barroso (2005, 2006), o termo multirregulação seria mais adequado, sendo importante entender e valorizar o papel dos indivíduos, estruturas formais, movimentos sociais, etc. na mediação e materialização dos fluxos reguladores. Isso posto, não caberia entender regulação como uma simples associação a regras fixas, imutáveis e emanadas do Estado de forma direcional no sentido topo-base. A regulação, conforme entendida, terminaria por associar não só o ajuste do sistema a regras, mas também a sua evolução e adaptação ao contexto histórico-social no qual está inserido, o que termina por inverter o fluxo regulatório para o sentido base-topo.

Adicionalmente, com base na definição de Barroso (2005, 2006), pôde-se assumir que, ao contrário do que a literatura polarizada do campo da avaliação da educação superior tende 
a sugerir, a regulação tanto pode implementar ações de cunho controlador (de cima para baixo), quando emancipador (de baixo para cima), numa espécie de regulação em duplo sentido, tanto do topo para a base quanto o inverso. Contextualizado essa perspectiva teórica no Sistema Nacional de Ensino Superior, pôde-se associar o movimento topo base à regulação nacional, cuja face somativa deslanchada pela ação do Governo Federal faz o sistema se mover, desenvolvendo-o e estabilizando-o, numa dinâmica permanente, cuja velocidade e direção seriam controladas pelas disputas entre os diversos públicos de interesse. Em sentido estrito, tal ação de nível meso se materializa nos processos de autorização, reconhecimento e renovação de reconhecimento de cursos, além daqueles relativos ao credenciamento/recredenciamento de instituições, baseados em processos avaliativos e justificados por critérios de qualidade que dão significado à qualidade esperada para o sistema.

Já o movimento base-topo pôde ser vinculado às ações em nível micro (microrregulação), ocorridas no âmbito das IES. Essas ações repercutiriam os resultados da regulação nacional, modificando a realidade institucional na direção sugerida pelo nível macro, mas também questionando o próprio significado de qualidade estabelecido nacionalmente. Nessa perspectiva, a microrregulação foi considerada como um processo crítico-construtivo e não meramente passivo, em função do seu potencial de influenciar a modificação dos critérios utilizados pelos processos avaliativos e, por consequência, os resultados por eles aferidos.

No caso concreto da pós-graduação, o processo (meso) regulatório vem gerando impacto direto na realidade dos cursos de mestrado e doutorado, ao mesmo tempo que tem permitido, no sentido inverso, o ajuste da regulação nacional por meio de alterações nos critérios de qualidade que subsidiam o processo avaliativo. A despeito de possíveis críticas à Avaliação da Capes, há que se reconhecer que os resultados avaliativos contribuem para a reflexão dos programas de pós-graduação sobre sua organização didático-pedagógica e científica. $^{41}$ Adicionalmente, puderam ser observadas contribuições dos programas, organizados pelas áreas de avaliação, para o ajuste desses próprios critérios, a saber: a) emergência da dimensão qualitativa no indicador de produção bibliográfica (Qualis); b) relativização da importância dos indicadores de titulação do corpo docente e de tempo de conclusão dos discentes; c) inovação da própria concepção de qualidade de mestrados e

\footnotetext{
41 A autorreflexão dos Programas se expressa no item "proposta de curso", que faz parte do relatório anual preenchido e enviado à Capes, também conhecido como "Coleta Capes". Mais recentemente tem sido utilizada a Plataforma Sucupira para esse registro.
} 
doutorados, como foi o caso dos mestrados profissionais, dos programas em associação e, até mesmo, em rede (apesar das forças de resistências e embates intra e entre áreas); e d) ascensão de indicadores de inserção internacional, inserção social e articulação com as atividades de graduação. Além disso, mesmo considerando que os resultados dos processos avaliativos vêm subsidiando a divisão elitizada dos recursos destinados à pesquisa e ao ensino de pósgraduação - como é o caso do Programa de Excelência Acadêmica (Proex) -, por outro lado, têm servido também para contemplar cursos e instituições localizados em regiões menos privilegiadas do País ou que precisam de apoio para se (re)estruturarem. ${ }^{42}$ Mesmo reconhecendo que poderia haver mais propostas ou mais recursos para reduzir tais desigualdades, as iniciativas ilustraram as possibilidades oferecidas pelos processos regulatórios, quando tomados de forma complementar aos processos avaliativos.

Contudo, no contexto dos cursos de graduação, a regulação tem se manifestado notadamente por meio do seu nível meso, destinando-se prioritariamente ao gerenciamento burocrático da entrada, permanência e saída de cursos de graduação e de IES. Sobre a desejável repercussão desses resultados nas decisões locais de gerenciamento da qualidade dos cursos ofertados, IES e dos próprios critérios de qualidade que dão base aos processos avaliativos e regulatórios, experiências como as relatadas por Rodrigues e Peixoto (2009) e Oliveira et al. (2013) sinalizaram o não uso de resultados gerados no âmbito do Sinaes. Também não foram observados movimentos sistematizados para ajustes nos critérios de qualidade que instrumentalizaram os processos avaliativos. As alterações de critérios observadas - como, por exemplo, a redução da importância dos docentes doutores e o aumento da importância dos docentes mestres - pareceram refletir mudança topo-base, impulsionadas mais por movimento esporádico de grupos de interesse, do que fruto de um processo de influência base-topo decorrente de um processo microrregulatório conforme aqui entendido.

Sobre semelhanças e diferenças observadas na pós-graduação e na graduação em relação aos processos regulatórios, pôde-se pontuar que a dinâmica de indicação direta dos Coordenadores de Áreas de Avaliação pelos programas e, consequentemente, de assentos no Conselho Técnico-Científico da Educação Superior (CTC-ES) e no Conselho Superior (CS) do órgão gestor do sistema nacional de pós-graduação - Capes - pareceu contribuir para a legitimação política dos critérios de qualidade, bem como dos resultados aferidos com base

\footnotetext{
${ }^{42}$ Programa Novas Fronteiras e Programa de Mestrado/Doutorado Interinstitucionais, ambos destinados à consolidação da pós-graduação em regiões carentes, estimulando a solidariedade entre cursos de pósgraduação.
} 
neles. Com isso, essa legitimação política (que por sua própria natureza não é isenta de críticas) pareceu se configurar como diferencial nas repercussões micro e meso regulatórias dos resultados avaliativos da pós-graduação, na forma do duplo sentido assinalado por Barroso (2005, 2006). Já no caso da graduação, a despeito de a proposta do Sinaes subsidiar processos regulatórios nos níveis meso e micro, o "decreto ponte" estabeleceu que a regulação se expressasse por meio de atos autorizativos do funcionamento de instituições de educação superior e de cursos, atrelando-a a atividades meramente burocráticas (BRASIL, 2006a), sem garantia da necessária repercussão ou uso dos resultados avaliativos na efetiva gestão da qualidade do sistema. ${ }^{43}$

Apesar desse quadro, o conceito de regulação foi assumido nessa discussão teórica como um processo capaz de gerenciar a qualidade da educação superior, por meio de decisões tomadas de forma a interferir na realidade dos níveis nacional e local, tanto no sentido ascendente quanto descendente. Considerou-se ainda que o processo regulatório está permeado por influências advindas das orientações e discussões capitaneadas por comunidades epistêmicas (nível macrorregulatório), materializando ações que podem ocorrer em níveis micro ou meso, conforme a capacidade de os sistemas avaliativos oferecerem subsídios aos processos decisórios. No centro, direcionando a regulação (de baixo para cima e de cima para baixo), estariam os critérios de qualidade que instrumentalizariam os processos avaliativos, gerando os resultados necessários para os fluxos regulatórios. Dessa forma, tomando-se Barroso $(2005,2006)$ como referência, propôs-se ressignificar a perspectiva trazida por Dias Sobrinho (2003) - e corroborada por Meneghel, Robl e Silva (2006) - de que a regulação ocorreria apenas em nível meso.

Resumindo as discussões em torno das relações entre critérios de qualidade, avaliação e regulação, foi possível considerar o primeiro conceito como detentor de um papel estruturante tanto para a materialização daquilo que inicialmente foi concebido por qualidade, condicionando o processo avaliativo responsável por sua aferição e, na sequência, as decisões/ações tomadas com base nos resultados exarados pela avaliação. Entendeu-se que é na estruturação dos critérios que se definem quais indicadores devem representar a realidade avaliada, bem como quais são os parâmetros para o seu julgamento. Uma vez que os critérios estabelecem os indicadores e parâmetros do processo avaliativo, terminam por estabelecer

\footnotetext{
${ }^{43}$ Apesar de o Sinaes ter incorporado no seu instrumento de avaliação de cursos de graduação presencial e a distância (fevereiro de 2012) as "ações decorrentes dos processos de avaliação do curso" (INEP, 2012a, p.6), essa medida não pareceu ser capaz de oferecer caminhos para que a regulação topo-base pudesse se configurar. Aparentemente a tentativa de abarcar o processo microrregulatório dentro do processo avaliativo não garantiu a possibilidade de se questionar o processo avaliativo, inerente ao próprio processo microrregulatório.
} 
também o juízo de valor advindo dos seus resultados. Além disso, é com base nos resultados apresentados pelo processo avaliativos, e por consequência, pelos próprios critérios de qualidade, que as ações regulatórias costumam ser empreendidas.

Considerando essa relação identificada entre avaliação, regulação e critérios de qualidade, foi possível sistematizar o próprio conceito de qualidade assumido nesta pesquisa, conforme indicado pela Figura 1, a seguir:

Figura 1 - Representação gráfica do conceito de qualidade na educação superior.

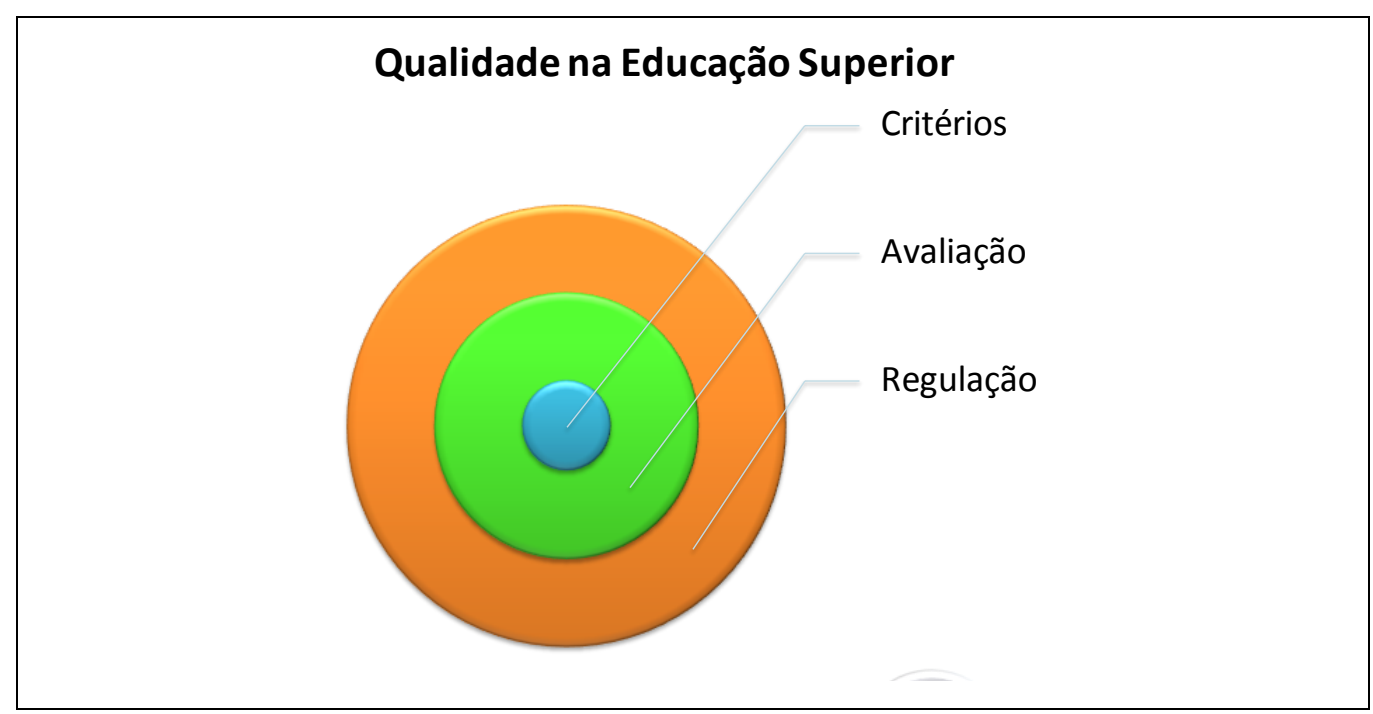

Fonte: Elaboração da autora.

Nessa figura, a qualidade na educação superior foi representada por meio de três elementos racionalmente sequenciados para facilitar o seu entendimento. Como ponto de partida, têm-se os critérios de qualidade - formados por indicadores e parâmetros que sintetizam o significado de qualidade construído a cada contexto histórico pelos interesses dos atores envolvidos. A partir dos critérios, seria possível organizar a avaliação - processo por meio do qual se diagnostica e valora o desempenho de cursos, instituições e programas, gerando resultados úteis à ação. Por fim, a regulação - processo por meio do qual se usam os resultados avaliativos para realizar ações nos níveis micro, meso ou macro, que visam aproximar a realidade à qualidade operacionalizada pelos critérios.

Considerando o dinamismo da realidade empírica, não seria de surpreender se tal sequência não se materializasse de fato. Porém, ela se presta ao propósito de evidenciar a centralidade dos critérios de qualidade para os processos de avaliação e de regulação conforme discutidos nesta pesquisa. A partir dessa discussão, propôs-se que nem a avaliação 
nem a regulação, como conceitos abstratos e descolados dos critérios de qualidade, poderiam ser colocadas, por si só, de um lado ou do outro em um contínuo de visões polarizadas.

Tal perspectiva remeteu ao entendimento da qualidade a partir do tripé: critérios, avaliação, regulação, localizando e especificando críticas, elogios e ajustes em cada um dos elementos. Nela, a avaliação foi apropriada como um elemento de ligação entre critérios de qualidade e regulação, cujos resultados podem se reverter em instrumentos de emancipação, controle, algo entre eles ou diferente deles, conforme os resultados aferidos com base nos critérios e aplicados por meio de processos regulatórios. Além disso, a noção de qualidade aqui assumida trouxe embutida uma perspectiva de mudança tanto da realidade (ao se alcançar aquilo que definiu o seu significado concreto de qualidade) quanto do conteúdo desse próprio significado, em função da dinâmica técnico-político-social que o contextualiza.

Assim, ante a centralidade dos critérios para a definição e gestão da qualidade na educação superior, procurou-se, na próxima seção, inseri-los no contexto da Política de Qualidade, evidenciando os possíveis significados para esse conceito. Para tanto, adentrou-se nas discussões sobre indicadores e parâmetros que vêm permeando o significado de qualidade da formação de professores, em geral, e da educação infantil e dos anos iniciais do ensino fundamental, em específico, permitindo a análise da política em foco.

\subsection{BASES PARA IDENTIFICAÇÃO OPERACIONAL DE QUALIDADE NA FORMAÇÃO DE PEDAGOGOS}

A discussão teórica até aqui desenvolvida permitiu entender os critérios, no contexto da Política de Qualidade, como um conjunto de indicadores e parâmetros que formalizam aquilo que se entende por um bom curso de formação de professores. Porém, a busca por esses indicadores e parâmetros que formam um critério de qualidade dos cursos de pedagogia foi uma tarefa árdua e sujeita a lacunas, não só em função das discussões polarizadas e divergências explícitas em torno das características de qualidade dos cursos em estudo, mas também pelas dificuldades oferecidas pelo isomorfismo do Sinaes. Ao contrário do que se imaginou inicialmente, esse sistema, ao estabelecer critérios padronizados para a avaliação de cursos de diversas áreas, terminou por oferecer muitos desafios à identificação de aspectos próprios da qualidade de um curso de graduação em determinada área de conhecimento, conforme relatado a seguir.

Nos termos do art. $4 .^{\circ}$ da lei que criou o Sinaes (BRASIL, 2004a), “a avaliação dos cursos de graduação tem por objetivo identificar as condições de ensino oferecidas aos 
estudantes, em especial as relativas ao perfil do corpo docente, às instalações físicas e à organização didático-pedagógica". Para cumprir esse propósito, o Sinaes mantém dois procedimentos paralelos - CPC e avaliações in loco - sem explicitar, no entanto, a interação e o alcance da qualidade medida por eles. Observou-se que o CPC foi definido como indicador de qualidade utilizado pelo Sinaes para fazer uma espécie de triagem dos cursos em processo de renovação de reconhecimento, os quais se submetem ao segundo procedimento avaliativo. Nos termos da Portaria Normativa n. ${ }^{\circ} 4$, de 5 de agosto de 2008, se o curso obtiver nota menor que três no CPC, recebe a avaliação in loco; no caso de a nota ser igual ou superior a três, o curso tem confirmado o CPC como resultado do processo avaliativo, sem necessidade de receber a visita avaliativa (BRASIL, 2008). ${ }^{44}$ Ocorre que essas medidas de qualidade podem gerar conceitos diferentes para um mesmo curso, sem que se tenham esclarecidos limites, divergências, convergências ou características que justifiquem objetivamente a substituição de uma nota pela outra.

No que se referiu especificamente ao instrumento utilizado pelo Sinaes para realizar as avaliações in loco, não se encontrou clareza sobre os parâmetros aplicados pelos avaliadores para aferir a qualidade do curso, notadamente na sua dimensão de organização didáticopedagógica. Além disso, os indicadores qualitativos utilizados pelo Sinaes para as visitas avaliativas suscitaram indagações sobre a validade e confiabilidade dos dados por eles gerados, tendo em vista lacunas teóricas do próprio conceito de indicador e de como ele se apresentou no sistema avaliativo em foco.

A análise das contribuições de Jannuzzi (2004, 2005), Rua (2004) e Soligo (2012) sobre o conceito de indicador no campo das políticas públicas, permitiu observar certo consenso em considerá-lo como uma medida que representa a realidade de forma aproximada, traduzindo, em geral, conceitos abstratos por meio de números. Corroborando essa conceituação, Bonnefoy e Armijo (2005) apresentaram, ainda, a ideia que medidas simples, que não relacionam dois ou mais dados quantitativos e que, portanto, não trazem embutida uma dimensão valorativa da realidade, poderiam ser identificadas como variáveis, mas não como indicadores.

Ilustrando sua afirmação, Bonnefoy e Armijo (2005) exemplificaram que medidas como as que identificam o número de desempregados se transformariam em indicadores apenas quando relacionadas à quantidade de membros de uma população específica (quando

\footnotetext{
${ }^{44}$ Apesar de essa regra geral encontrar-se prevista legalmente, há condicionantes em torno da operacionalização das visitas e da geração do Conceito do Curso que não permite adotá-la de forma linear, sem observar diversas particularidades, como por exemplo: a regulação específica de cursos oferecidos por instituições estaduais ou a possibilidade de que um curso com CPC maior que três, ainda assim, requisitasse uma visita avaliativa.
} 
passariam a indicar a sua taxa de desempregados), uma vez que sintetizariam uma expectativa de valor (positivo/negativo; bom/ruim) em torno da medida apurada. Porém, não esclareceram como tal juízo de valor se estabeleceria em torno de taxas e índices, nem como indicadores conseguiriam formar referenciais de qualidade compartilhados por todos, sem que valores e experiências pessoais trouxessem sentidos diferentes para uma mesma medida apurada.

Sem destacar elementos novos que esclarecessem essa discussão, Rua (2004) também afirmou ser preferível a utilização de taxas e índices como indicadores. Já Soligo (2012) e Jannuzzi (2004, 2005) não diferenciaram a relevância ou pertinência dos indicadores em função do tipo de medida apresentada por sua escala, mas nos exemplos apresentados por eles não foram encontrados indicadores medidos por categorias ou mesmo por números absolutos. Além disso, para Jannuzzi (2005), a questão da escala quantitativa na apuração dos indicadores pode ser entendida do ponto de vista da dicotomia entre o objetivo e o subjetivo. Segundo o autor, $[\ldots]$

[...] indicadores objetivos referem-se a ocorrências concretas ou a entes empíricos da realidade social, construídos a partir das estatísticas públicas disponíveis, como o percentual de domicílios com acesso à rede de água, a taxa de desemprego, a taxa de evasão escolar ou o risco de acidentes de trabalho. Os indicadores subjetivos, por outro lado, correspondem a medidas construídas a partir da avaliação dos indivíduos ou especialistas com relação a diferentes aspectos da realidade, levantados em pesquisas de opinião pública ou grupos de discussão, como a avaliação da qualidade de vida, o nível de confiança nas instituições, a percepção da corrupção, a performance dos governantes (JANNUZZI, 2005, p. 143).

Em síntese, o autor apresentou o entendimento de que para serem objetivos explícitos ou tangíveis - os indicadores devem: (a) representar ocorrências concretas; e (b) ser definido a partir de estatísticas. Contudo, na discussão sobre critérios de qualidade para a oferta de cursos de pedagogia, os indicadores trazidos pelo Sinaes impuseram a necessidade de considerar alternativas a esse entendimento. A realidade observada no âmbito da qualidade da educação superior evidenciou que muitas ocorrências concretas são mais bem representadas por meio de categorias do que números, sem invalidar a sua objetividade.

Assim, a partir da priorização do concreto no processo de análise de indicadores como constructo de pesquisa, foi possível questionar a sua definição até aqui revisada, sobretudo aquelas que polarizam os indicadores em torno do quantitativo/qualitativo ou do subjetivo/objetivo. As contribuições de Minayo (2009) corroboraram esses questionamentos ao permitirem depreender que, ao contrário do que o senso comum costuma indicar, os números estão presentes não só na escala de medida de indicadores quantitativos - geralmente associados a aspectos tangíveis, computáveis, ou diretamente observáveis da realidade -, 
como também nos indicadores qualitativos - geralmente associados à representação de aspectos intangíveis, não computáveis ou observáveis por meio da subjetividade humana.

Conforme esclareceu a autora, desde a década de 1920, muitas escalas têm sido desenvolvidas para utilizar a métrica quantitativa para objetivar aspectos da realidade inerentes aos sujeitos, tais como aqueles relacionados a opiniões, relações, vivências intersubjetivas e outros ligados à percepção dos indivíduos. ${ }^{45}$ Tais escalas se apresentaram, então, como uma possibilidade metodologicamente válida para explicitar a subjetividade por meio de números. Sendo assim, as escalas psicométricas puderam ser visualizadas como um contraponto em torno da separação dos indicadores entre qualitativos e quantitativos (MINAYO, 2009).

Em certa medida, a psicometria quebrou a lógica dicotômica entre o quantitativo (visto até então como ocorrências tangíveis, explicitadas pelos números) e o qualitativo (ocorrências intangíveis, subjetivamente representadas) ao introduzirem um terceiro elemento que misturou os elementos dessa polarização (ocorrências intangíveis, mas explicitadas pelos números). Porém, mesmo apresentando elementos novos à relação entre indicadores qualitativos e quantitativos, as escalas psicométricas não invalidaram a perspectiva assumida por Jannuzzi (2005), que polarizou os indicadores entre aqueles que representam ocorrências tangíveis, medidas por uma escala numérica (chamados de indicadores objetivos), e aqueles (chamados de indicadores subjetivos), que representam ocorrências intangíveis, sejam elas medidas por escalas numéricas ou não. Porém, no caso específico dos cursos de pedagogia, a dicotomia oferecida por esse quadro conceitual não conseguiu explicar aqueles indicadores que, apesar de representarem ocorrências concretas da realidade, não se adequavam a uma escala numérica.

Nesse contexto, encontrou-se em Minayo (2009) o alerta de que os números podem não ser a única saída para a representação objetiva da realidade. Para a autora, a fundamentação hermenêutica permite traduzir fatos concretos, possibilitando que indicadores não numéricos afiram tanto ocorrências intangíveis da realidade (ideias, percepções, etc. algumas vezes objetivadas por escalas psicométricas), quanto ocorrências tangíveis (em geral, associadas à representação por números).

Seguindo essa perspectiva, foi possível considerar, a partir do caso concreto dos indicadores utilizados pelo Sinaes para avaliar cursos de graduação, que quando não se podem gerar estatísticas para representar um aspecto tangível da realidade, ainda assim ele pode ser

\footnotetext{
${ }^{45}$ Exemplo são as escalas de Thurstone (concordo... discordo) e Likert (concordo totalmente; concordo;
} indiferente; discordo; discordo totalmente), entre outras. 
objetivamente representado por meio de conceitos. Ilustrando essa possibilidade, encontrou-se o exemplo das atividades práticas desenvolvidas ao longo do curso de pedagogia, que podem ser representadas por meio das características inerentes a esse constructo, tais como: utilização de laboratórios pedagógicos, de brinquedotecas e/ou execução de projetos sistematizados de interação teoria-prática que poderiam representar, entre outros aspectos, o quanto o curso proporciona aos alunos oportunidades de desenvolver as abordagens teóricas trabalhadas no curso de forma contextualizada, independentemente dos estágios. Há que se destacar, ainda, que as oportunidades de articulação entre teoria e prática desenvolvidas ao longo de um determinado curso constituem-se em ocorrências concretas, sendo aparentemente simplório tratá-las como produto da subjetividade humana em função de uma possível dificuldade em ser medida por meio de uma escala numérica. Assim, construir indicadores objetivos exclusivamente a partir de uma medida estatística, conforme sugeriu Jannuzzi (2005), pode levar ao entendimento de que, fora da base numérica, as ocorrências, ainda que passíveis de observação direta, são medidas apenas por meio de indicadores subjetivos (percepções referenciadas pela visão de mundo e experiências individuais).

Para demonstrar o incômodo gerado por essa perspectiva conceitual, destacou-se, na Figura 2, o indicador 1.6: conteúdos curriculares. Esse indicador está presente no instrumento do Sinaes para avaliar cursos de graduação em geral e de pedagogia em particular e serve como exemplo para essa análise.

Figura 2 - Indicador 1.6: conteúdos curriculares.

\begin{tabular}{|l|c|l|}
\hline Indicador & Conceito & Critério de Análise \\
\hline $\begin{array}{l}\text { 1.6. Conteúdos } \\
\text { curriculares }\end{array}$ & 1 & $\begin{array}{l}\text { Quando os conteúdos curriculares previstos/implantados não possibilitam o } \\
\text { desenvolvimento do perfil profissional do egresso, considerando, em uma análise } \\
\text { sistêmica e global, os aspectos: atualização, adequação das cargas horárias (em horas) } \\
\text { e adequação da bibliografia. }\end{array}$ \\
\cline { 2 - 4 } & 2 & $\begin{array}{l}\text { Quando os conteúdos curriculares previstos/implantados possibilitam, de maneira } \\
\text { insuficiente, o desenvolvimento do perfil profissional do egresso, considerando, em uma } \\
\text { análise sistêmica e global, os aspectos: atualização, adequação das cargas horárias (em } \\
\text { horas) e adequação da bibliografia. }\end{array}$ \\
\cline { 2 - 4 } & \multirow{2}{*}{3} & $\begin{array}{l}\text { Quando os conteúdos curriculares previstos/implantados possibilitam, de maneira } \\
\text { suficiente, o desenvolvimento do perfil profissional do egresso, considerando, em uma } \\
\text { análise sistêmica e global, os aspectos: atualização, adequação das cargas horárias (em } \\
\text { horas) e adequação da bibliografia. }\end{array}$ \\
\cline { 2 - 4 } & \multirow{2}{*}{5} & $\begin{array}{l}\text { Quando os conteúdos curriculares previstos/implantados possibilitam, muito bem, o } \\
\text { desenvolvimento do perfil profissional do egresso, considerando, em uma análise } \\
\text { sistêmica e global, os aspectos: atualização, adequação das cargas horárias (em horas) } \\
\text { e adequação da bibliografia. }\end{array}$ \\
\cline { 2 - 4 } & $\begin{array}{l}\text { Quando os conteúdos curriculares previstos/implantados possibilitam, de maneira } \\
\text { excelente, o desenvolvimento do perfil profissional do egresso, considerando, em uma } \\
\text { análise sistêmica e global, os aspectos: atualização, adequação das cargas horárias (em } \\
\text { horas) e adequação da bibliografia. }\end{array}$ \\
\hline
\end{tabular}

Fonte: MEC/Inep/Daes. Instrumento de avaliação de cursos de graduação presencial e a distância (fevereiro de 2012) (INEP, 2012a). 
O indicador em questão, para o qual não se dispõe de estatísticas públicas, vem sendo apurado pelo Sinaes por meio da avaliação de especialistas e assumiu a forma subjetiva, conforme a teorização de Jannuzzi (2005), ao medir o quanto os conteúdos curriculares possibilitam o desenvolvimento do perfil profissional do egresso, a partir de aspectos como atualização, adequação das cargas horárias e das bibliografias. Porém, esse caso concreto permitiu questionar a validade e confiabilidade da medida gerada, tendo em vista que os aspectos citados são tangíveis, presentes na realidade do curso, mas que não foram objetivados pelo indicador.

Em consequência, o indicador no exemplo em análise não foi capaz de representar, mesmo que de forma aproximada, os conteúdos trazidos por um curso, suscitando dúvidas sobre o que são conteúdos atualizados e como eles podem ser identificados na realidade de um curso de pedagogia. Outras dúvidas também emergiram: o que configura a adequação de cargas horárias e como diferenciá-la entre os componentes curriculares? Quais são os aspectos que indicam a adequação de uma bibliografia? Como a diversidade no tratamento dos diversos conjuntos de conteúdos disciplinares foi medida em relação à atualização, à carga horária e/ou à bibliografia de forma a representar uma unidade? Como os aspectos atualização, carga horária e bibliografia devem ser considerados para atender, ou não, a um determinado perfil profissional do egresso?

Essas perguntas ilustraram a possibilidade de várias ocorrências concretas e tangíveis da realidade que poderiam ser objetivadas a partir de categorias. Sem essas respostas, entre outras que poderiam ser destacadas, dificilmente uma mesma realidade de curso seria medida de forma confiável: é muito provável que especialistas diferentes avaliassem de forma diferente um mesmo curso sem que as bases dessas diferenças ficassem explicitadas. A partir desse entendimento, foi possível considerar que a ausência de estatísticas em uma dada realidade não pareceu implicar, necessariamente, que tal realidade devesse ser medida à revelia de categorias conceituais sistematizadas, explícitas, e porque não dizer, objetivas. Assim, vislumbrou-se que, se por um lado, as escalas psicométricas quebram a lógica entre o quantitativo (numérico) e o qualitativo (não numérico) na classificação dos indicadores, por outro, a fundamentação hermenêutica permitiu ressignificar a discussão entre indicadores subjetivos e objetivos neste trabalho.

Adicionalmente, no exemplo trazido anteriormente, observou-se que a utilização dos chamados indicadores subjetivos favoreceu certa mistura entre a função descritiva e valorativa do indicador. Por exemplo, não foi possível estabelecer a diferença entre os conteúdos curriculares que atendem de forma "muito bem" em relação àqueles que atendem de forma 
"excelente" ou "suficiente" o desenvolvimento do perfil profissional do egresso, uma vez que a descrição da realidade foi estabelecida por meio do próprio juízo de valor, sem que os parâmetros envolvidos nessa avaliação tivessem sido explicitados. Nesse sentido, o exemplo serviu ainda para questionar as contribuições de Bonnefoy e Armijo (2005) em torno da perspectiva do indicador ter de trazer de forma inerente uma dimensão de valor. Tal concepção dos autores, quando aplicada no exemplo analisado, terminou por fragilizar o próprio indicador. A descrição da realidade cedeu lugar ao seu julgamento, sem que, no entanto, a base desse julgamento, advindo da própria medida apurada pelo indicador estivesse presente. Em consequência, o julgamento realizado pareceu pouco capaz de expressar um significado concreto.

Nessa perspectiva, o conjunto teórico e empírico analisado neste trabalho sobre o conceito de indicadores permitiu observar que, independentemente de se referirem a aspectos internos ou externos ao indivíduo, os indicadores se beneficiam de metodologias explícitas, que permitam maior confiabilidade na sua replicação, seja por meio de estatísticas públicas, escalas psicométricas ou fundamentação hermenêutica. No exemplo analisado, a construção de indicadores, sem que a metodologia envolvida na sua apuração fosse explicitada por meio de uma escala objetiva de medida (numérica ou não numérica), repercutiu em dúvidas sobre a confiabilidade dos resultados e sobre a possibilidade de pouca confiabilidade do retrato apresentado da realidade. Nesse sentido, pôde-se considerar que: (i) a objetividade na mensuração de aspectos tangíveis da realidade não precisa configurar-se em arena exclusiva da métrica quantitativa; e (ii) a representação de aspectos não computáveis ou intangíveis da realidade por meio de indicadores não deve dispensar a objetividade das escalas de medida, sob pena de representar coisa nenhuma.

Além disso, considerando o contexto deste trabalho, reforçou-se o entendimento de que, conceitualmente, um indicador não se confunde com o processo avaliativo. $\mathrm{O}$ indicador especifica características de uma dada realidade, representando-a de forma aproximada por meio de uma escala de medidas. Por sua vez, tais características podem ser utilizadas para parametrizar sentidos de qualidades úteis ao desenvolvimento de processos avaliativos. Em termos conceituais, tal posição permitiu considerar o indicador como um constructo em separado dos parâmetros construídos, com base na sua escala, para avaliar a realidade medida. Mesmo partilhando da mesma escala, enquanto o indicador a utiliza para apurar uma realidade, o parâmetro classifica as diversas possibilidades de medidas previstas na escala em termos de valor ou adequação. Nesse sentido, o indicador e o parâmetro de julgamento não se confundem. Como consequência, os parâmetros servem ao papel de valoração do indicador, 
podendo ser agregado a ele, ou não. Tal separação entre a escala de medida do indicador e o parâmetro de valorização da realidade apresentou-se como necessária neste trabalho uma vez que pareceu dar transparência e confiabilidade ao processo avaliativo.

Enfatizou-se ainda que a realidade considerada neste trabalho apontou para a necessidade de a escala de medida de um indicador ser construída a partir da possibilidade de ocorrências concretas e observáveis, seja por meio de números ou não. Em termos das possibilidades para a construção dessas escalas, Babbie (1995) discutiu quatro tipos: (i) nominal (categorizando a realidade a partir de nomes, ideias ou conceitos); (ii) ordinal (hierarquizando categorias dentro de um contínuo); (iii) intervalar (estabelecendo faixas, nas quais a realidade observada de forma quantitativa pode ser encaixada); ou (iv) de razão (estatísticas ou dados quantitativos).

Adicionalmente, dentro dessa perspectiva de se definir critério de qualidade por meio do conceito de indicador, considerou-se que nem mesmo o indicador medido por uma escala de razão pode ser tomado, por si só, como objetivo. Entendeu-se que, como todas as construções humanas, o processo de elaboração de indicadores é condicionado por algum tipo de interesse que, por si só, é capaz de definir sua subjetividade, independentemente da escala utilizada. Porém, num movimento dialético, assumiu-se igualmente que o indicador tende a ser objetivo na mesma proporção em que explicita a base da escolha de sua construção, em detrimento de outras possíveis. Decorrente dessa ideia, propôs-se o entendimento de que todo indicador é subjetivo e que se aproxima da objetividade não pela tradução da realidade em estatísticas, mas, sim, pela sua capacidade de permitir, de forma clara, possíveis revisões na sua definição e forma de apuração, sempre que se necessitar.

Sintetizando essa discussão em torno de indicadores como base para a construção de critérios e, portanto, da operacionalização do conceito de qualidade, destacaram-se os seguintes pontos: (i) compartilhou-se do entendimento de Bertolin (2007) de que um indicador é um elemento representativo da realidade, o qual serve como base para elaboração de um juízo de valor sobre aquilo que ele representa; (ii) dessa forma, estabeleceu-se a diferenciação entre indicadores, parâmetros e critérios de qualidade: enquanto um indicador permite aproximações a uma determinada ocorrência, caracterizando-a por meio de números ou de categorias, o parâmetro estabelece as regras para valorização ou avaliação da qualidade daquilo que foi apurado; (iii) juntos, indicadores e parâmetros, formam um critério de qualidade que se altera conforme o contexto histórico em que está inserido; (iv) quando se aplica um critério de qualidade a uma realidade concreta, entra em curso um processo avaliativo, cujo resultado pode subsidiar processos regulatórios. 
Por fim, entendeu-se que a discussão conceitual sobre indicadores foi necessária não só para poder analisar as bases daquilo que foi considerado pelo Sinaes como critérios de qualidade para avaliar os cursos de pedagogia, como também, na outra ponta, para permitir identificar aqueles critérios efetivamente seguidos pelos cursos do Parfor. Ademais, permitiu evidenciar a necessidade de uma discussão teórico-legal-empírica em torno de características da qualidade de cursos de pedagogia que pudessem ser utilizadas como medidas tanto para retratar a realidade como para parametrizá-la em torno do que é bom ou adequado no processo formativo de professores da educação infantil e dos anos iniciais do ensino fundamental. Para alcançar tais características, foram analisados os principais elementos e discussões nas quais estão inseridas, agregando-os em três dimensões: (i) das concepções de formação de professores; (ii) da legislação; e (iii) das experiências internacionais sobre a qualidade da formação docente, a seguir explicitadas.

\subsubsection{Concepções de formação de professores}

Como ponto de partida para a discussão sobre características de cursos que podem subsidiar a identificação de indicadores e parâmetros de qualidade na formação de professores, em geral, e pedagogos, em específico, analisaram-se as principais tendências teóricas no campo que refletiram, em alguma medida, a estrutura e a organização dos cursos em análise. Segundo Araújo (2009), tais tendências orbitam em torno de três abordagens teóricas, a saber: racionalidade técnica (centrada no conhecimento teórico para a solução instrumental de problemas), racionalidade prática (focada no conhecimento decorrente da prática, por meio da reflexão sobre a ação e voltada à realidade concreta) e racionalidade crítica (baseada no conhecimento voltado a reflexões para a compreensão e a transformação social).

Colocadas em uma perspectiva de evolução pela autora citada, tais abordagens assumiram, no pensamento dela, uma linha evolucionista de concepções teóricas, mesmo tendo sido admitida a possibilidade da igual presença de todas no universo que congrega os cursos de formação docente. Por outro lado, encontrou-se em Andrade (2011), Pereira (1999), Libâneo (2008) e Rios (2010) argumentos que relacionaram essas abordagens sem a perspectiva de superação, adequação ou maior pertinência de uma ante a outra, relatada anteriormente. A partir da contribuição desses autores, foi possível dialetizar a relação entre as abordagens, considerando que a perspectiva técnica de formação de professores procura valorizar a apropriação do conhecimento teórico disponível para a sua aplicação na realidade 
de sala de aula, trazendo como contraponto crítico a possibilidade de essa abordagem favorecer a apreensão da teoria de forma abstrata, sem dar ênfase à complexidade das relações humanas, às condições de trabalho do professor no seu dia a dia escolar e à realidade social que o circunda. Já a abordagem prática foi apropriada por meio de uma centralidade na reflexão da atividade docente como geradora de conhecimento e significados, buscando transformar conhecimentos teóricos em técnicas específicas para resolver problemas singulares, derivados da dinâmica da realidade. Como reação a ela, foi possível observar alguns argumentos de que essa abordagem favorece uma dimensão instrumental do conhecimento, desvalorizando, de certa forma, a teoria no processo de formação do docente. Por fim, na crítica, observou-se sua caracterização a partir da sua ênfase à formação do professor por meio da análise do contexto histórico e social e do seu papel na formação dos alunos, questionando não só a escola, mas a própria sociedade. Entre os argumentos que a tencionaram, destacaram-se aqueles que apontaram a tendência de essa abordagem valorizar pouco os conteúdos teóricos no processo de formação, deixando-os vazios de conteúdos, mas plenos de uma perspectiva engajada para a construção de uma nova realidade social.

Para discutir melhor essa configuração polarizada entre concepções de formação de professores, decidiu-se analisar mais detalhadamente o pensamento de Schön (2000), em função da repercussão de suas ideias sobre a categorização das abordagens de formação de professores, permitindo estabelecer pontes entre elas. Esse autor propôs uma formação prático-reflexiva para que os profissionais em geral, inclusive professores, pudessem ser capazes de lidar com situações imprevistas no ambiente de trabalho. Para ele, o contexto contemporâneo tornou insuficiente a simples aplicação da teoria e da técnica derivadas de um conhecimento estático para atender aos desafios de um ambiente produtivo dinâmico e imprevisível. Então, haveria a necessidade de despertar os profissionais em formação para o uso de estratégias inovadoras, visando atender mais adequadamente às situações inusitadas com as quais eles se defrontariam no cotidiano laboral (SCHÖN, 2000).

Considerando, então, que incertezas, singularidade e conflitos formariam zonas indeterminadas da prática (que não estariam sistematizadas na teoria), Schön (2000) pontuou a necessidade de se desenvolver nos profissionais um talento que se assemelhasse a uma arte para lidar com elas. Para tanto, propôs o desenvolvimento da reflexão-na-ação (competência que sintetiza a capacidade de análise da zona indeterminada da prática, não prevista na teoria) para permitir uma ação inovadora. Como meio para desenvolver essa competência, sugeriu que o processo formativo do profissional se aproximasse das situações de trabalho, 
favorecendo a identificação e a reflexão sobre ocorrências fora do script da técnica descrita pela teoria, e, portanto, a inovação.

Ancorando sua proposta na perspectiva reflexiva, o autor aparentemente inaugurou a perspectiva de polarização entre as suas ideias de formação profissional e aquelas denominadas por ele de racionalidade técnica. Para Schön (2000), a racionalidade técnica prepararia os profissionais apenas para resolver problemas comuns, com base na aplicação da teoria e da técnica derivadas do conhecimento sistemático, de preferência científico, sem incorporar a dinamicidade e os desafios inerentes ao exercício do labor. Como resultado, assumiu que a abordagem técnica materializaria o conhecer-na-ação - também definido por ele como o exercício da prática profissional de forma automática, com a utilização do conhecimento do campo de forma abstrata, sem reflexão e ação inovadora sobre as ocorrências inusitadas. Mesmo valendo-se do conhecimento sistematizado ou teórico como ponto de partida para a reflexão-na-ação, Schön (2000) inexplicavelmente desvalorizou as construções teóricas sistematizadas na sua proposta formativa, passando a considerá-las como esfera de preocupações focadas na racionalidade técnica. Com isso, aparentemente, pavimentou o caminho para a polarização de ideias sobre concepções de formação profissional.

Porém, assumindo o hiperempirismo dialético como método de análise nesse trabalho, as diferenças estabelecidas pelo autor entre o conhecer-na-ação e o refletir-na-ação parecem gozar de uma relação de implicação múltipla ${ }^{46}$ e não uma simples polarização. Conhecer-naação e refletir-na-ação, longe de se oporem, apresentaram uma mesma base de referência, que em vez de separá-los, os une: o conhecimento profissional.

Conhecimento profissional foi assumido por Schön (2000) como um conjunto de valores, procedimentos e normas em torno dos quais se formulam objetivos e diretrizes para a ação, determinando o que constitui uma conduta profissional aceitável. Se esse corpo teórico de conhecimento (sistematizado por uma perspectiva de racionalidade técnica para oferecer soluções "prontas" para as ocorrências mais comuns da realidade) fosse dispensável à racionalidade prática, como poderia o profissional identificar zonas indeterminadas da prática, para as quais o exercício do talento artístico profissional seria necessário? Além disso, tomando-se literalmente a "contradição" existente entre a racionalidade técnica e a prática, ter-se-ia a necessidade de se refletir-na-ação sobre tudo, inclusive sobre a (re)invenção da roda. Assim, a suposta contradição entre o refletir-na-ação e o conhecer-na-ação poderia levar

\footnotetext{
${ }^{46}$ Interseções e pontos de afinidade que podem ser encontrados entre elementos que aparentemente se anulam mutuamente.
} 
a uma interpretação da realidade não como ela é, mas, sim, por meio de extremos idealizados. De um lado, tudo seria tratado como imprevisível (no qual a falta de um corpo teórico mais geral, aplicável a situações comuns, levaria à necessidade de criar tudo, a todo o momento, dispensando o conhecimento sistematizado pela teoria, como os críticos da proposta práticareflexiva sugerem); e do outro, tudo seria tratado como previsível (no qual a falta de reflexão levaria a um engessamento teórico e à aplicação de técnicas descontextualizadas e ineficientes para situações sempre singulares, numa visão ortodoxa da prática-reflexiva).

Apesar de literalmente contrapor sua proposta à racionalidade técnica, Schön (2000) partiu da reflexão - de cunho mais abstrato e, portanto, associado a aspectos teóricos - para chegar à ação. Aparentemente, suas ideias levaram a uma ressignificação do conhecimento sistematizado de forma a torná-lo conectado com as mudanças cada vez mais velozes da realidade, incentivando uma permanente inovação no repertório das técnicas disponíveis. Nesse sentido, pode-se entender que seu ponto de divergência em relação à racionalidade técnica não está em função do binômio teoria/prática, mas, sim, em relação ao binômio ação/inovação. Talvez por isso, o autor tenha assumido ser necessário ao ensino profissional não só incentivar o estudante à aplicação de técnicas previamente elaboradas, decorrentes do arcabouço teórico sistematizado (conhecer-na-ação), mas também instigá-lo a criar possibilidades inovadoras de ação, sempre que identificado como necessário no exercício da prática (reflexão-na-ação). Em linhas gerais, Schön (2000) propôs a transição da formação do especialista, que tem um comportamento modelado por teorias e sua forma de aplicação, para a formação do pesquisador, que pode ter até a atuação de um especialista, mas que é capaz de modelar um novo sistema, aperfeiçoando ou criando alternativas às soluções já existentes. Em ambos os casos, o conhecimento sistematizado pareceu ser fundamental, seja para aplicá-lo em situações comuns, seja para transformá-lo, seja para adaptá-lo à realidade quando ela exigir inovação.

Vale enfatizar, ainda, que embora no pensamento de Schön (2000) a prática seja valorizada como meio para a formação do talento artístico profissional, os exemplos e propostas de formação reflexiva por ele abordados não deslocam o espaço de aprendizagem dos bancos acadêmicos para o mundo real do trabalho. Segundo o autor, [...]

[...] a maioria dos escritórios, fábricas, firmas e clínicas não está organizada para as tarefas exigentes da iniciação e da educação [...] Uma aula prática é um ambiente projetado para a tarefa de aprender uma prática. Em um contexto que se aproxima de um mundo prático, os estudantes aprendem fazendo, ainda que sua atividade fique longe do mundo real do trabalho. Eles aprendem assumindo projetos que estimulam e simplificam a prática ou projetos reais sob uma supervisão minuciosa, Uma aula 
prática é um mundo virtual, relativamente livre de pressões, distrações e riscos do mundo ao qual, no entanto, ele diz respeito. Fica no espaço intermediário entre o mundo prático, a camada leiga da vida ordinária e o mundo esotérico da academia. (SCHÖN, 2000, p.40).

Assim, o eixo de argumentação do autor em foco pareceu ser o de aproximar a academia da prática, e não de trocar o ambiente acadêmico pelo laboral como espaço privilegiado de formação profissional. Para o autor, o profissional ao chegar ao ambiente de trabalho nas organizações precisa já estar preparado para identificar incertezas e utilizar a reflexão-na-ação para elaborar um problema coerente, bem como agir de forma consistente para resolvê-lo. Nessa perspectiva, se o ambiente organizacional fosse utilizado como espaço da prática reflexiva, precisaria estar aberto à mudança para incentivar e favorecer o desenvolvimento do processo criativo individual, além de permitir o erro em prol do aprendizado e de oferecer um tempo de aprendizagem desconectado com os prazos negociais. Porém, as organizações nem sempre são espaços receptivos às aprendizagens, à inovação e à adaptação às incertezas ambientais, o que vale considerar que nem toda prática conduz, necessariamente, à reflexão-na-ação (inovação) (SCHÖN, 2000).

Nesse ponto, cabe esclarecer a ideia de aprendizagem organizacional, trazida por Argyris e Schön (1978), pioneiros nos estudos sobre organizações de aprendizagem. ${ }^{47}$ Para os autores a aprendizagem organizacional divide-se em dois tipos: i) circuito único, no qual os indivíduos que compõem a organização agem de forma a modificar seus comportamentos considerando os resultados obtidos ante aqueles esperados (correção); e ii) circuito duplo, quando os indivíduos questionam as premissas e modo de atuação que levaram a determinado resultado, agindo não apenas para corrigi-lo, mas também para modificar os valores e os comportamentos em prol de resultados mais efetivos (inovação). As ideias de aprendizagem organizacional de circuito único e de circuito duplo são muito próximas às que Schön (2000) denominou, respectivamente, de conhecimento-na-ação (competência que permite executar tarefas de forma automática, atendendo a situações previsíveis) e reflexão-na-ação (competência que permite executar tarefas quando a situação foge ao "padrão normal"). Porém, há diferenças importantes entre os conceitos de formação reflexiva e aprendizagem organizacional, as quais acrescentam a atitude ou vontade de fazer, no primeiro caso, e a oportunidade de fazer, no segundo, como importantes aspectos a serem considerados.

\footnotetext{
${ }^{47}$ Termo que define uma área de conhecimento dentro da teoria das organizações, que estuda modelos e teorias de como as organizações aprendem, adaptando-se aos ambientes competitivos.
} 
Conforme discutido, a formação reflexiva preconiza que o profissional aprenda a encarar a realidade de forma a identificar situações que exijam a formulação dos problemas específicos para os quais se possa oferecer como resposta a inovação. Essa proposta, embora pareça se confundir com a aprendizagem de circuito duplo, difere-se dela porque no ambiente organizacional o profissional não só precisará saber agir de forma reflexiva; precisará, ainda, querer agir assim. No contraponto ao saber agir e ao querer agir de forma reflexiva, há ainda, no ambiente de trabalho, a questão da oportunidade de ser inovador: o profissional terá de superar as chamadas forças de resistências às mudanças - discutidas por Strebel (1993) e já citadas - para materializar inovações advindas de sua reflexão.

Nesse sentido, não surpreende que Schön (2000) tenha considerado o próprio ambiente acadêmico - conservatórios de música ou laboratórios da faculdade de arquitetura como espaços privilegiados de formação reflexiva. Não se conseguiu localizar na obra desse autor a defesa pela utilização direta dos próprios espaços de exercício profissional como ambiente de formação do talento artístico profissional (competência de agir de forma criativa/inovadora), mesmo porque sua proposta era que o profissional já chegasse apto para refletir-na-ação ao realizar seu trabalho. Além disso, a utilização do ambiente de trabalho como espaço de formação do profissional reflexivo exigiria que as organizações estivessem preparadas para as mudanças inerentes à reflexão-na-ação, caso contrário inibiriam o processo criativo quando os indivíduos ainda estivessem sendo despertados para o talento artístico profissional.

No âmbito da docência, a perspectiva de formação profissional voltada a uma reflexão-na-ação pareceu ter sinalizado para o professor não só uma nova forma de desenvolver as competências de seus alunos por meio da prática como processo formativo, como também uma nova abordagem de formação do próprio professor. Nesse sentido, o conhecimento sobre o talento artístico profissional, sistematizado por Schön (2000), instigou o campo a refletir-na-ação sobre o próprio processo formativo de modo a torná-lo inovador. Porém, contraditoriamente, o caminho seguido pareceu ter sinalizado para o desenvolvimento de habilidades ou práticas decorrentes do conhecimento teórico já sistematizado, sem que, necessariamente, tais habilidades estivessem associadas à inovação. 
Relatórios e textos de discussões difundidos por organismos internacionais ${ }^{48}$ que discutem ou incentivam experiências reflexivas, aparentemente, assumiram como racionalidade prática o simples uso de conhecimento e habilidades sistematizadas teoricamente. Nesse sentido, tais textos pareceram ressignificar a racionalidade técnica - que para Schön (2000) se referia aos conhecimentos e práticas estáveis, descoladas das turbulências do contexto econômico-social - para assumi-las como simples campo do domínio teórico, sem vinculação com o exercício da prática. Além disso, nesses documentos pareceu inexistir uma distinção clara entre a proposta original de Schön (2000), que inseriu a vivência laboral no processo de formação do talento profissional, daquele decorrente da ideia de fazer da escola, como organização de atuação profissional do professor, por si só, um espaço de aprendizagem, mesmo antes que o talento profissional (formação para ser inovador) tivesse sido desenvolvido. Além disso, nesses documentos também não foi possível identificar referência ao constructo organização de aprendizagem, seja na perspectiva de Argyris e Schön (1978) seja na de outros teóricos da área.

Assim, na perspectiva deste trabalho, quando se observou a difusão da ideia de que a escola, como espaço da formação do docente em serviço, poderia desenvolver a reflexão-naação (processo de formação do talento profissional), considerou-se ter havido certa confusão em torno das ideias originais de Donald Schön, seja pela falta de referência à inovação como objetivo do processo de reflexão, seja pelo fato de vários documentos de circulação internacional proporem o espaço profissional (escola) como ambiente de formação, quando o autor destacou que o processo formativo deve ocorrer na academia para que o talento profissional já chegue pronto para o trabalho. Ou ainda, seja pelo fato de a escola não ter sido tratada como organização de aprendizagem (capaz de realizar aprendizagem em circuito duplo, ao mobilizar seus colaboradores a agir de forma inovadora), o que exigiria, nesse caso, o deslocamento do debate sobre o pensamento do autor em foco do campo de formação de professores para o de comportamento organizacional, estabelecendo-se os limites e possibilidades para que tal formação ocorresse.

Assumiu-se, pois, que, para Schön (2000), não é qualquer prática que leva à construção de um talento profissional, mas, sim, aquela exercitada no âmbito acadêmico, capaz de promover processo de reflexão quando o profissional se encontra diante de zonas indeterminadas da prática. Seguindo o raciocínio do autor, nesses casos específicos, o

48 São exemplos desses documentos: “Educação um Tesouro a Descobrir”, Relatório para a Unesco da Comissão Internacional sobre Educação para o século XXI; "Desafíos y posibilidades en la formación de maestros: na perspectiva desde América del Norte”, produzido pela Universidade Pedagógica Nacional do México e difundida pela Organização dos Estados Americanos (OEA), entre outros. 
conhecimento sistematizado não faria sentido, pois inexistiriam respostas prontas para uma situação que ainda não foi prevista ou identificada. Assim, o profissional precisaria desenvolver, a partir de sua experiência e inventividade, uma ação criativa, não presente na teoria. Reitera-se, porém, que, embora o autor não tenha assumido isso, aparentemente, a criação/inovação só pareceu ser possível porque estava fortemente inspirada/alicerçada nos conhecimentos sistematizados, os quais permitiram o início do processo de reflexão para identificação das zonas indeterminadas da prática.

Por outro lado, reconheceu-se que, no âmbito do que Araújo (2009) chamou de racionalidade prática, não houve distinção clara entre ação e inovação, tampouco ponderações sobre os seus desdobramentos em torno da centralidade/relativização do conhecimento teórico. Ilustrou essa situação o Relatório da Conferência Internacional sobre a profissão docente, Building a High-Quality Teaching Profession: Lessons from around the world (OCDE, 2011), que trouxe a própria escola, lócus do trabalho docente, como o espaço de formação do professor reflexivo, sem que o compromisso com a inovação tivesse sido assumido ou questões relativas ao processo de aprendizagem organizacional e seus desdobramentos como ambiente propício ou não à inovação tivessem sido consideradas. Talvez por isso, Rodrigues e Kuenzer (2007) fizeram críticas e alertas às ideias de Schön (2000), assumindo-as dentro do campo da epistemologia da prática, a qual enfatizaria uma dimensão instrumental do conhecimento, desvalorizando, de certa forma, a concepção teórica. Entre outras ponderações feitas pelas autoras, encontrou-se o argumento de que a visão excessivamente instrumentalizada da teoria poderia conduzir os futuros professores à inserção em situações concretas de trabalho antes mesmo da apropriação de categorias teóricas e metodológicas que lhes permitissem intervir com competência na realidade escolar.

Além desses, há outro conjunto de argumentos que se propõe a contestar a racionalidade prática, denominado por Araújo (2009) como racionalidade crítica. Esta última abordagem procurou polarizar em relação à primeira, enfatizando a reflexão na formação do professor a partir de questões mais amplas, referentes ao desenvolvimento econômico-social, bem como aos princípios de equidade a ele relacionados. Essa perspectiva tem como uma das fontes de argumentação o trabalho de Giroux (1997), que propôs uma superação das racionalidades técnica e prática da formação de professores em prol da criticidade e do questionamento do docente sobre as concepções de sociedade e do processo ensinoaprendizagem, visando analisar os aspectos históricos e sociais nos quais a escola está inserida, transformando-os proativamente para a construção de uma sociedade mais justa. Para tanto, a racionalidade crítica pressupôs o envolvimento ativo dos professores na seleção 
de conteúdo e produção de material cultural socialmente adaptado, respeitando, entre outras, as diferenças de aprendizagem e a história de vida dos alunos.

Assim, analisando as argumentações teóricas sobre a formação de professores, pôde-se entender uma tendência na sua segmentação em categorias contraditórias, porém levando a uma dicotomização forçada de caráter abstrato. Aparentemente, a simples categorização provocou antagonismos e divergências, relacionando as diversas características teóricas por meio da contestação. Dessa forma, tal categorização tendeu a provocar o afastamento, inclusive, de aspectos do ideário compartilhado por todos, como se apenas uma das abordagens pudesse proporcionar ao professor em formação condições de atuar com qualidade no processo de construção do conhecimento pelo aluno.

Em uma perspectiva de qualidade de formação de professores denominada plural, Rios (2010) propôs uma nova perspectiva para a análise dessas categorias. Para ela, deve-se associar a noção de competências à qualidade da formação docente, destacando as dimensões técnica (capacidade de lidar com o conteúdo e [re]construí-lo com o aluno), estética (sensibilidade para criar e inovar), ética (orientação da ação fundada em princípios coletivos) e de solidariedade política (construção coletiva de sociedade e participação cidadã). Segundo a autora, tais dimensões são indissociáveis, não cabendo falar de um aspecto sem considerar a existência do outro. Com isso, as preocupações do "o que" e do "como" ensinar, presentes mais prontamente nas abordagens tecnicistas, devem estar associadas à dimensão política/crítica da educação do cidadão e da sua função na sociedade, em prol de uma formação docente com qualidade.

Essa posição também foi compartilhada por Libâneo (2008), na medida em que considerou que o melhor programa de formação de professores é aquele que contempla o currículo e a metodologia a serem empregados com os alunos dentro de uma perspectiva abrangente de pensar a formação de professores, evitando o reducionismo teórico do processo de formação. Para o autor "uma postura política não descarta a atividade instrumental" (LIBÂNEO, 2008, p. 74). Dessa forma, considerou que a prática de formação deve envolver pelo menos quatro requisitos: cultura científica, conteúdos instrumentais, espaços de aprendizagem, além de convicções éticas e políticas.

Do ponto de vista epistemológico, Gurvitch (1987) permitiu situar essa quarta perspectiva de concepção de formação de professores - plural, segundo Rios (2010) - por meio da reciprocidade de perspectivas, que leva em conta a possibilidade de a polarização entre elementos de um fenômeno ser só aparente por tratar-se de um todo. As relações dialéticas teoricamente observadas entre as racionalidades técnica, prática e crítica sugeriram 
que elas fazem parte de uma mesma totalidade no processo de formação docente, não admitindo separação por contribuírem de forma igualmente necessária ao processo formativo.

Apesar desse entendimento, admitiu-se que no caso da Política de Qualidade, as quatro perspectivas de concepção de formação de professores discutidas, podem ter sido apropriadas em um sentido de qualidade diferente daquele que se discutiu aqui. Dessa forma, esse tema será mais adequadamente retomado quando da discussão empírica em torno da concepção de formação de professores presentes nos critérios de qualidade do Parfor e do Sinaes na seção 4.2.1.

\subsubsection{Aspectos de qualidade destacados pela legislação brasileira}

No que se referiu aos critérios de qualidade legalmente estabelecidos para a oferta e avaliação de cursos de formação inicial de professores, em geral, e de pedagogia, em particular, localizaram-se nas diretrizes curriculares nacionais os principais balizamentos para a sua definição. A centralidade das DCN na orientação da qualidade dessa formação foi amparada pelo Decreto n. ${ }^{\circ}$ 3.276, de 6 de dezembro de 1999, que dispôs sobre a formação em nível superior de professores para atuar na educação básica (BRASIL, 1999a), ${ }^{49}$ pela Lei 9.131, de 24 de novembro de 1995, que estabeleceu as avaliações periódicas de instituições e cursos de nível superior (BRASIL, 1995), bem como, posteriormente, pelas definições presentes na lei que criou o Sinaes (BRASIL, 2004a).

Mesmo considerando que o curso de pedagogia, foco deste trabalho, possui diretrizes curriculares nacionais específicas (BRASIL, 2006b), conforme discutida na subseção 1.4.2, entendeu-se que as orientações emanadas do CNE para a formação de professores em geral, por meio da Resolução CNE/CP n. ${ }^{\circ}$ 1/2002, de 18 de fevereiro de 2002 (BRASIL, 2002), deveriam ser aqui analisadas. Sustentou essa opção a perspectiva de que aspectos particulares da qualidade do curso em foco poderiam ser beneficiados pelo contexto das discussões e regras estabelecidas para os demais cursos de formação de professores. Além disso, o CNE não se pronunciou oficialmente sobre os limites da aplicabilidade das duas diretrizes,

\footnotetext{
${ }^{49}$ Esse decreto regula o art. 62 da LDB (BRASIL, 1996).
} 
permitindo considerá-las como igualmente válidas aos cursos de pedagogia, apesar de apresentarem algumas divergências. ${ }^{50}$

Nesse sentido, analisou-se o diagnóstico contido no Parecer CNE/CP n. ${ }^{\circ}$ 9, de 09 de maio de 2001 (BRASIL, 2001), que subsidiou a elaboração das DCN voltadas à formação de professores, destacando dele os principais problemas dos cursos de formação. A partir desses problemas, foi possível fazer o movimento contrário, identificando, por meio das críticas, aquelas características entendidas no âmbito do documento como necessárias à qualidade da formação do professor. Nesse processo, foram considerados os aspectos diretamente observáveis na estrutura de um curso, de modo a subsidiar a prospecção de critérios associados à sua qualidade. Como resultado, emergiram do referido documento legal as seguintes características que denotaram qualidade para um curso de formação inicial de professor, a saber:

a) consideração do repertório de conhecimento dos professores em formação, o que inclui, por um lado, a possibilidade de os professores-aprendizes disporem de conhecimentos adquiridos em função de sua vivência da escola de educação básica e, por outro, terem deficiência em conhecimentos básicos de português e matemática, por exemplo, decorrentes das próprias deficiências da educação básica no País;

b) tratamento adequado dos conteúdos, tornando claro quais são aqueles que o professor em formação deve aprender, distinguindo-os entre o objeto de ensino (conteúdo) e sua transposição didática (estratégias e procedimentos de ensino);

c) oportunidades para desenvolvimento cultural, entendidas como acesso a livros, revistas, vídeos, filmes, produções culturais de naturezas diversas, por meio de espaços sistematicamente planejados para favorecer leituras, discussões informais, troca de opiniões, participação em movimentos sociais, debates sobre temas atuais, exposições, espetáculos e outras formas de manifestação cultural e profissional;

d) amplo tratamento da atuação profissional do professor da educação, incluindo, além da regência, a atuação nos projetos da escola relacionados aos alunos, à comunidade, ao sistema educacional e à atuação dos professores;

e) concepção ampla de prática, exigindo que planejamento, execução e avaliação das práticas durante estágio estejam apoiados nas reflexões desenvolvidas nos cursos de

\footnotetext{
${ }^{50}$ Aparentemente as DCN para a formação de professores não se propuseram a alcançar todas as especificidades curriculares dos cursos de licenciatura, dividindo parte desse papel com as diretrizes curriculares específicas de bacharelados. No caso da pedagogia, ambas as diretrizes curriculares restringiram o curso sob a perspectiva da licenciatura, sem que, no entanto, aspectos como carga horária diferenciada, organização das disciplinas entre diferentes eixos articuladores e núcleos de estudo e a própria concepção de docência fossem claramente tratados pelo CNE.
} 
formação, permitindo uma visão crítica da teoria e da estrutura curricular do curso. Deve configurar-se numa tarefa para toda a equipe de formadores, e não apenas para o "supervisor de estágio". O tempo dos estágios deve estar diluído durante o curso, além de permitir acompanhar a rotina do trabalho pedagógico durante um período contínuo, em que se pode ver o desenvolvimento das propostas, a dinâmica do grupo e da própria escola e outros aspectos não observáveis em estágios pontuais;

f) tratamento adequado da pesquisa, por meio da valorização da participação do aluno na construção de um projeto pedagógico institucional, na elaboração de um programa de curso e de planos de aula que envolvam pesquisa bibliográfica, seleção de material pedagógico, etc., implicando uma atividade investigativa;

g) presença de conteúdos relativos às tecnologias da informação e da comunicação, garantindo que o futuro professor aprenda a usar, no exercício da docência, computador, rádio, vídeo, gravador, calculadora, internet e a lidar com programas e softwares educativos, além de desenvolver, no cotidiano do curso, os conteúdos curriculares das diferentes áreas e disciplinas, por meio das diferentes tecnologias;

h) consideração às especificidades próprias dos níveis e/ou modalidades em que são atendidos os alunos da educação básica, relativa à questão da educação de jovens e adultos, aos alunos com necessidades educacionais especiais nas classes comuns dos sistemas de ensino e aos indígenas.

Essas características permitiram a análise da estrutura do curso de pedagogia, oferecendo bases para traduzir a oferta realizada pelo Parfor, bem como as avaliações do curso realizadas pelo Sinaes, presentes no capítulo 3 deste trabalho. Por outro lado, no que se refere à formulação das Diretrizes Curriculares Nacionais para a Formação de Professores da Educação Básica em nível superior, curso de licenciatura de graduação plena, aprovadas por meio da Resolução CNE/CP n. ${ }^{\circ}$ 1/2002, de 18 de fevereiro de 2002 (BRASIL, 2002), considerou-se que grande parte das possíveis soluções oferecidas pelo diagnóstico pareceram se perder quando da fixação das diretrizes.

O documento legal mostrou-se mais comprometido em permitir a flexibilização da estrutura dos cursos do que em estabelecer conteúdos significativos e necessários à formação docente, bem como a sua organização. Além disso, a simples qualificação dos desenhos curriculares como flexíveis e inovadores não pareceu orientar adequadamente a organização didático-pedagógica da formação docente, notadamente em torno de como tratar a questão da especificidade de grupos como os indígenas, os alunos com deficiência e aqueles com distorção idade/série. Conforme explicitado nos arts. 10 e 14 das referidas diretrizes, o 
desenho curricular do curso foi deixado a cargo da própria IES. No entanto, poucos foram os esclarecimentos encontrados para a realização deste trabalho.

A própria estrutura curricular, concebida por meio de seis eixos articuladores, previstos no art. 11, caracterizou-se pela generalidade. A ideia de eixos articuladores não permitiu identificar, ao certo, as características que deveriam ser perseguidas quando da oferta desses cursos. Dessa forma, não foi possível ter clareza do que, por exemplo, diferenciaria o "eixo articulador da disciplinaridade e da interdisciplinaridade", do "eixo articulador da formação comum com a formação específica" ou do "eixo articulador dos diferentes âmbitos de conhecimento profissional".

Além disso, a própria definição dos conteúdos, na tentativa de flexibilizar ao máximo o desenho curricular, terminou prescindindo de detalhamento. Desse modo, de acordo com o parágrafo $3 .^{\circ}$ do art. 6..$^{\circ}$ das DCN de formação de professores, "aspectos da cultura geral e profissional" concorrem igualmente com os "conhecimentos sobre crianças, adolescentes, jovens e adultos, aí incluídas as especificidades dos alunos com necessidades educacionais especiais e as das comunidades indígenas". Adicionalmente, o "conhecimento sobre dimensão cultural, social, política e econômica da educação" deveria ser articulado com os "conteúdos das áreas de conhecimento que serão objeto de ensino" e com o "conhecimento pedagógico". No entanto, todos esses conteúdos foram tratados isoladamente pelas diretrizes, sem que fossem oferecidas pistas de como articulá-los. Por fim, essas DCN estabeleceram que o curso deveria contemplar "conhecimento advindo da experiência" na constituição de competências profissionais dos egressos, mas também sem oferecer referências sobre o que buscar nessa experiência, uma vez que ela poderia reproduzir tanto virtudes como deficiências presentes no repertório de conhecimento trazido pelos professores em formação.

No contraponto a esses aspectos, outros aparecem de forma muito clara no texto das diretrizes de formação de professores, a saber: a ênfase teórico-prática; a pesquisa como geradora de reflexão e construção do conhecimento; e o desenvolvimento de competência para a ação. Conforme foi possível observar, o art. 3. ${ }^{\circ}$ das referidas diretrizes, ao estabelecer a formação por competências, a interação entre teoria e prática e a pesquisa com foco no processo de ensino-aprendizagem como aspectos fundamentais para nortear a organização curricular desses cursos, reportou-se a ideias presentes no pensamento de Schön (2000).

No entanto, tornou-se necessário destacar algumas sutilezas no tratamento desses conceitos no âmbito das DCN de formação de professores, os quais se diferenciam daqueles presentes no autor citado. A pesquisa foi visualizada no texto do documento legal como uma possibilidade de reforçar a aplicação da teoria na prática, sem trazer necessariamente a 
perspectiva de inovar, promovendo uma ação que não vinha sendo desenvolvida ou era feita de forma pouco eficiente. O inciso III do art. 3. ${ }^{\circ}$ dessas diretrizes (BRASIL, 2002) declarou explicitamente a visão da pesquisa como mobilizadora da ação, e não necessariamente da inovação. Nesse sentido, depreendeu-se que não era o conhecimento novo, desbravado por meio da reflexão-na-ação que estava sendo buscado, mas, sim, a habilidade em se aplicar aquele conhecimento já sistematizado teoricamente.

Reforçando esse entendimento, apesar de essa diretriz orientar os projetos pedagógicos dos cursos de formação docente para o princípio metodológico da ação-reflexão-ação, em nenhum dos seus artigos foi encontrada referência à palavra inovação entre as competências listadas. Nesse ponto, é importante reforçar que o refletir-na-ação, proposto por Schön (2000) como uma competência a ser desenvolvida entre os alunos, não se limitava apenas à ação. $\mathrm{O}$ autor propôs, principalmente, desenvolver o talento artístico profissional em prol da criatividade para lidar com casos fora de padrões esperados de normalidade, de modo a promover uma atuação profissional mais concatenada com as turbulências e imprevistos característicos de um ambiente social cada vez mais dinâmico e complexo.

No entanto, independentemente das diferenças entre a perspectiva de competência discutida por Schön (2000) e aquela que permeou as diretrizes de formação de professores, foi preciso reforçar que em ambos prevaleceu a formação profissional voltada à intervenção, quando do enfrentamento das situações de trabalho. Essa necessidade de ação/inovação constitui-se numa das principais preocupações quando se discute a formação baseada em competências. Conforme esclareceu Brígido (2001), o conceito de competência passa pela necessidade de articulação dos conhecimentos teóricos presentes nos cursos de formação profissional, com as habilidades necessárias para aplicar tal conhecimento, bem como com a atitude de querer aplicá-los em situações concretas de trabalho.

Polarizando com essa perspectiva, autores como Dias e López (2003) criticaram a abordagem de competência nos cursos de formação de professores, alegando a sua estreita ligação com a lógica produtiva e sua vinculação com a expansão do capital sobre o trabalho. Por outro lado, pôde-se considerar neste trabalho que o conceito de competência não exclui a possibilidade de que essa mobilização do conhecimento para a ação transforme a realidade no sentido crítico e emancipatório sugerido pelas próprias autoras, muito menos que uma postura crítica ou socialmente engajada seja deixada de lado em função apenas da prática. A análise das DCN de formação de professores sugeriu que as competências referidas pelo documento englobaria o conteúdo teórico do que fazer (conhecimento), a utilização das técnicas de como fazer (habilidade) e a conscientização para o querer fazer do professor (atitude). Dessa forma, 
a ênfase do curso formativo estaria no conteúdo estudado, na habilidade do como fazer, e também na mobilização de vontades para a ação efetiva do professor formado, posteriormente, quando em atuação na escola.

De acordo com Gadotti (2003), a educação não é neutra, constituindo-se, também em um ato político. Freire (2001) destacou ainda o conhecimento como fundamental para a capacidade da organização política em prol da transformação social. Nesse sentido, o cerne dessa questão levantada por Dias e López (2003) não estaria, pois, na formação por competência, em si, mas no conteúdo abordado no curso. Assumindo o modelo de competência como um modelo para a organização da formação, aparentemente qualquer propósito político previsto para o processo educativo poderia beneficiar-se dele.

Dentro dessa perspectiva, ao contrário do que sugeriram Dias e López (2003), o conceito de competência nas DCN da formação de professores não pareceu estar restrito a uma visão de educação voltada à produtividade capitalista, à maximização de lucros e à descontextualização das reais carências sociais da população. Ela abarcaria os propósitos educativos na sua totalidade, comportando a sólida discussão teórica, bem como a análise das repercussões econômicas, políticas e sociais do processo educacional, em todas as suas extensões. Corroborando essa ideia, as DCN de formação de professores (BRASIL, 2002), no seu art. $6 .^{\circ}$, definiram como uma das competências esperadas do egresso formado, o seu comprometimento com os valores democráticos, bem como a compreensão do papel social da escola.

Nesse sentido, considerou-se simplista entender que a organização curricular, com foco no desenvolvimento de competência determinaria, por si só, a atuação mais ou menos engajada do professor em formação ou de uma forma mais ou menos crítica da realidade que o cerca. Além disso, de acordo com Fleury e Fleury (2001), os conhecimentos e know how só adquirem status de competência quando são comunicados e utilizados: "[...] a noção de competência aparece, assim, associada a verbos como: saber, agir, mobilizar recursos, integrar saberes múltiplos e complexos, saber aprender, saber engajar-se, assumir responsabilidades, ter visão estratégica" (FLEURY; FLEURY, 2001, p. 187).

Depreendeu-se, portanto, que o modelo de competência, também analisado por autores como Hirata (1994) e Zarifian (1996), implicaria agregar ao conhecimento adquirido ou construído as noções de habilidade e atitudes em prol da ação, não restringindo, a priori, o sentido dessa atuação. Nessa lógica, possuir um título ou diploma não significa, necessariamente, habilidade ou vontade para mobilizar esses conhecimentos para desenvolver uma atividade. O que ganhou centralidade nesse modelo de competência foi a tentativa de 
garantir, por meio do desenvolvimento de atitudes engajadas, o uso efetivo de conhecimentos e habilidades, adquiridos via cursos regulares, ou via a aprendizagem autônoma, ${ }^{51}$ em prol da solução de problemas.

Dessa forma, entendeu-se que o modelo de competência trazido pelas DCN de formação de professores sintetizou a aprendizagem voltada para intervenções na realidade, e não o simples acúmulo de conhecimento, certificado pelo diploma ou a ação desprovida de conteúdo positivamente transformador. Tal modelo não pareceu oferecer limitações ao processo de formação docente, notadamente no que pode ser considerado como conteúdo político, mais ou menos adequado do processo formativo. Por outro lado, reflexões sobre as atitudes dos professores - também entendidas como motivação para agir - apresentaram-se como uma importante fronteira no discurso da competência para a formação de professores.

As reflexões de Sacristán (2008) e Libâneo (2008) dão pistas sobre alguns desses limites. Numa síntese do pensamento dos autores, foi possível destacar que as condições de trabalho oferecidas na escola e as próprias motivações do professor, como pessoa guiada por interesses e condicionantes histórico-culturais e econômicos se apresentariam como limitadores à sua ação, independentemente do curso de formação por ele frequentado. Além disso, no âmbito da Rede Estrado, Oliveira et al. [200-?] alertou que a discussão teórica sobre a formação do professor reflexivo ocorreu de forma restrita, uma vez que pouco abordou as condições a partir das quais o trabalho docente é realizado, centrando fortemente no professor a responsabilidade de apresentar respostas aos problemas surgidos da realidade prática

O modelo de competência na formação de professores trouxe, como perspectiva de sucesso, a mobilização efetiva de conhecimentos e habilidades construídos durante o curso para resolver problemas, como, por exemplo, os que envolvem aprendizagem/comportamento dos alunos da educação básica. Porém, visto dessa forma, entendeu-se que tal modelo não poderia limitar-se apenas aos bancos escolares, precisaria estender-se também ao ambiente de trabalho no qual o professor atuaria. Assim, para ser efetivo, a perspectiva de competência para a formação de docentes com qualidade não poderia restringir-se apenas ao curso de formação, como as orientações legais fazem supor.

Pesquisas nacionais que tratam do efeito do conhecimento adquirido em curso na realização das tarefas laborais demonstram que as condições psicossociais do ambiente interno de trabalho interferem diretamente no desempenho dos trabalhadores no cargo ocupado por eles após o curso (ALVES; TAMAYO, 1993; LEITÃO, 1996; LIMA; BORGES-

51 O inciso $\mathrm{V}$ do art. 5. $^{\circ}$ das DCN de formação de professores (BRASIL, 2002) permite a certificação de competências adquiridas fora do curso, igualando-a àquelas nele construídas. 
ANDRADE; VIEIRA, 1989; PANTOJA; LIMA; BORGES-ANDRADE, 2001; VARGAS, 1999).

Em uma ampla análise da literatura sobre o tema, Oliveira-Castro (1999) observou que a aprendizagem e/ou reações favoráveis ao curso não garante melhoria duradoura nos níveis individuais de desempenho, motivação no trabalho e comprometimento. Segundo ela, isso pareceu indicar que variáveis presentes no ambiente de trabalho interagem com variáveis individuais e do próprio curso para influenciar o impacto deste na tarefa desenvolvida pelo trabalhador. Se fosse possível transpor diretamente as conclusões às quais chegou essa autora para os cursos de formação docente, afirmar-se-ia que nem mesmo um curso preocupado em gerar atitudes competentes e engajadas dos professores seria capaz, por si só, de garantir o impacto positivo na escola, uma vez que seria necessário contar com o suporte dentro do ambiente escolar para praticar aquilo que fora aprendido.

Evidentemente os resultados dessas pesquisas, embora bastante sugestivos, não podem ser tomados como verdade absoluta sobre os impactos dos cursos de formação de professores para a educação básica, mesmo considerando a unidade escolar como uma organização e a licenciatura um curso mais alargado do que aqueles que deram origem às conclusões acima. Generalizar para outro contexto os resultados das pesquisas relatadas seria temerário. Porém, elas ilustram uma hipótese que precisa ser empiricamente testada no campo de formação de professores. O fato é que há evidências de meandros a serem explorados entre a concepção de um curso para formar um professor competente e os seus efeitos reais na sala de aula.

Disputando espaço com as DCN de formação de professores, as diretrizes da licenciatura em pedagogia não aderiram ao modelo de competência: pareceram propor uma articulação entre teoria e prática, dentro de uma perspectiva de racionalidade crítica, conforme estabelecido em seu art. 2. ${ }^{\circ}$, parágrafo $2 .^{\circ}$ e reiterado no inciso I do art. 6..$^{\circ}$ (BRASIL, 2006b). Adicionalmente, na definição do perfil do pedagogo formado, o inciso I do art. $5 .^{\circ}$ reforçou a atuação do egresso do curso em prol de uma sociedade igualitária e justa, no entanto, sem superar as orientações no mesmo sentido, contidas nas DCN de formação de professores.

Além disso, do ponto de vista da docência, enquanto para as DCN da licenciatura em pedagogia a atuação do egresso se estabelece tanto em sala de aula quanto na gestão educacional de uma forma mais ampla, seja em espaços escolares, seja em espaços não escolares, a concepção de docência trazida pelas DCN de formação de professores se reverteu na atuação do egresso em salas de aula. Considerando, então, essa diferença, ponderou-se que a relação entre uma e outra norma, no que tange à definição de docência, dificilmente poderia ser resolvida fora do procedimento dialético da polarização. De um lado, as DCN da 
licenciatura em pedagogia trouxeram uma perspectiva ampliada da docência; do outro, a de formação de professores entende a docência a partir do trabalho em sala de aula.

Com isso, a discussão sobre características de um curso de formação de professores da educação infantil e dos anos iniciais do ensino fundamental, ressaltadas pelas orientações legais, ofereceu alguns balizamentos em torno de sua qualidade. Entretanto, trouxe também desafios para a organização da oferta e avaliação dos cursos de formação de professores, notadamente os de pedagogia, diante de polarizações, limites e pouca especificidade da legislação em torno da operacionalização de critérios de qualidade para essa formação.

\subsubsection{Experiências internacionais sobre qualidade na formação docente}

Em âmbito internacional, a questão da qualidade da formação de professores está centrada na abordagem de que o docente, por meio da sua ação em sala de aula, seria capaz de fazer a diferença na educação básica. A proposição inerente a essa abordagem é a de que os professores se bem formados poderiam liderar as reformas necessárias da base para o topo, tendo como perspectiva a provisão dos trabalhadores aptos à condução de processos produtivos cada vez mais sofisticados, como também, em certa medida, cidadãos que cobram seus direitos e cumprem seus deveres na convivência social. Embora tal perspectiva não restrinja o trabalho do professor à sala de aula, foi com base nessa atuação para o desenvolvimento do aluno que se desenvolveram as experiências internacionais em torno da qualidade da formação docente.

De acordo com a Organização para a Cooperação e Desenvolvimento (OCDE, 2011), a educação inicial de professores varia entre os países, sendo possível, no entanto, identificar alguns princípios partilhados por eles:

a) os sistemas educacionais se beneficiam de perfis claros e concisos sobre as competências que os professores precisam possuir para ministrar suas aulas, servindo de guia para a formação inicial e continuada, os processos de avaliação e desenvolvimento profissional, além do avanço na carreira;

b) os programas de formação inicial de professores estão baseados em modelos que privilegiam a preparação profissional por meio da experiência direta em escolas, diminuindo a preparação notadamente acadêmica, em busca de um equilíbrio entre teoria e prática; 
c) há perspectiva de aprendizagem continuada, fazendo com que os esforços no processo de qualificação não estejam concentrados na formação inicial e permitindo que se abram novas rotas ao longo de tempo em prol do efetivo preparo profissional.

No Brasil, observou-se que certos princípios difundidos internacionalmente estão presentes na proposta de formação de professores para educação básica. Por um lado, as DCN para formação de professores procuram associar o processo de formação docente aos conteúdos oferecidos na educação básica. Por outro, preocupam-se em formar professores por meio do desenvolvimento de competências, com ênfase em estágios e práticas. Todavia, embora as orientações curriculares brasileiras destaquem a importância das atividades práticas, há pouca especificidade de como tais atividades poderiam se desenvolver, seja nas relações entre as instituições formadoras e as escolas de educação básica, seja no planejamento das atividades e no tempo em que os futuros professores devem conviver no espaço escolar para exercitar suas habilidades como docentes.

No que se refere especificamente ao perfil profissional do docente formado, não se observou a definição, no modelo brasileiro, de perfis claros para a atuação do professor, marcando uma disparidade concreta entre o que aqui ocorre e a experiência internacional. Em Freitas, Chacon e Girling (2012) encontrou-se, inclusive, uma lista de competências ${ }^{52}$ a serem desenvolvidas entre os professores em formação, orientando aspectos de qualidade a serem buscado na atuação profissional desses egressos. Porém, as preocupações trazidas pelos autores não pareceram guardar ressonância na realidade nacional.

Talvez por isso, a análise da dinâmica existente nos cursos de formação brasileiros tenha indicado uma situação de descompasso entre o que se espera de um curso de licenciatura e a realidade encontrada no Brasil. Gatti (2010) relatou que as licenciaturas em matemática, ciências biológicas e letras possuem certa tensão entre a concentração de conteúdos disciplinares, mais voltados ao bacharelado, em detrimento das preocupações didático-metodológicas, centrais na licenciatura. Nos cursos de licenciatura em ciências biológicas, apenas $10 \%$ da carga horária estão voltados à formação para docência. No curso de letras, esse percentual sobe para $11 \%$. Apenas o caso da matemática, que atinge o percentual de $30 \%$, é considerado como equilibrado pela autora. Sobre a questão das práticas

52 Em síntese, as competências citadas pelos autores referem-se: à habilidade de ouvir, ser ouvido e manter o diálogo; ao respeito às opiniões divergentes; ao trabalho em equipe; à habilidade política para a execução de projetos; à atitude de colocar ideias em prática; ao uso da voz como proteção de doenças ligadas às cordas vocais; à habilidade de lidar com o conflito e o estresse excessivo; ao respeito às singularidades de todos; ao uso das TIC na dinâmica do trabalho; à elaboração de planos de intervenção com base em resultados de pesquisa, avaliações de larga escala e indicadores educacionais públicos; à ação pautada em princípios éticos, respeito ao meio ambiente e à diversidade sexual, física/mental, social, étnica, cultural e religiosa das pessoas (FREITAS; CHACON; GIRLING, 2012). 
exigidas pelas diretrizes curriculares para a formação desses professores, Gatti (2010, p. 1373) as classifica como "problemática, pois ora se coloca que estão embutidas em diversas disciplinas, sem especificação clara, ora aparecem em separado, mas com ementas muito vagas". A autora destacou, ainda, a quase ausência de conteúdos relacionados às tecnologias de ensino, à política de educação nacional e aos sistemas educacionais, como também a fluidez e pouca especificidade das atividades complementares (seminários, atividades culturais, etc.).

No que tange especificamente às diretrizes curriculares da licenciatura em pedagogia, foi possível observar que sua ênfase na ampliação dos conteúdos necessários ao processo de formação inicial está em contraposição à tendência internacional relatada pela OCDE. Ao estruturar o currículo em prol da concentração de todas as certificações necessárias ao conhecimento mais especializado do pedagogo em nível de graduação, de certa forma, as DCN do curso parecem contribuir para fragilizar o processo de educação continuada.

Já na experiência específica dos cursos de formação de professores para os anos iniciais da educação básica, promovidos pela Universidade do Novo México, Estados Unidos e relatada por Sánchez e Gutierrez-Gomez (2009), observou-se a tendência de simplificação da formação inicial, na licenciatura, com a perspectiva de complementação de estudos em nível de pós-graduação, focando na atividade desenvolvida em sala de aula. Segundo o relato, para obter o título de licenciado para a docência nos anos iniciais do ensino fundamental, os professores-aprendizes precisam cumprir, durante os dois primeiros anos, créditos em disciplinas relacionadas às ciências sociais, humanidades e ciências, além de disciplinas relacionadas à psicologia da educação, diversidade cultural e linguística (para atender à especificidade local de alfabetizar crianças que falam outros idiomas que não só o inglês e provêm de diversas origens de nacionalidade familiar), além de tecnologias educacionais. É obrigatório que os estudantes de licenciatura participem de um programa de ensino para a educação básica, atuando em sala de aula, para avançar no curso de licenciatura e poder concluí-lo, cumprindo os créditos em estudos específicos para a docência, como as disciplinas relacionadas à metodologia e à didática.

No México, Carvajal e Villarreal (2009) destacaram que a proposta atual de formação de professores pretende que eles desenvolvam competências em cinco campos, a saber: a) habilidades intelectuais específicas; b) domínio dos conteúdos a serem ensinados; c) competências didáticas; d) identidade profissional e ética; e e) capacidade de analisar as condições dos alunos e das escolas, para oferecer respostas a possíveis problemas. As autoras observaram e destacaram o enfoque das competências para formação de docentes, com base 
na perspectiva da ação-reflexão-ação, mas sem pontuar a questão da inovação enfatizada por Schön (2000).

A experiência mexicana adota períodos de observação e prática docente em situações reais das escolas de nível fundamental (anos iniciais) e em contextos diversos, desde o primeiro ano dos cursos de formação inicial. Esse período de trabalho de campo vai se ampliando cada vez mais ao longo do curso, até que os estudantes fiquem nas escolas por todo um ciclo de atividades. A proposta é a de que os alunos vivenciem os diversos aspetos do exercício docente, desde o ensino até o desenho e aplicação de propostas didáticas sobre conteúdos específicos para que eles exercitem a análise das formas de se proceder, identificando práticas adequadas e a sua própria prática, tendo como referência a especificidade da escola em que se dá o processo de formação.

Na experiência da Austrália, a questão da qualidade da formação de professores ganhou uma repercussão nacional, uma vez que está institucionalizada como política pública. Nela destacou-se o papel desempenhado pelo Australian Institute for Teaching and School Leadership (AITSL), uma agência pública, criada em 1997 para promover a excelência na atuação de professores e diretores de escolas da educação básica.

Inicialmente o trabalho da agência esteve voltado à definição e ao acompanhamento de padrões de desempenho de professores e diretores escolares. Em 2011, a AITSL passou a atuar também na elaboração de regras para o processo de credenciamento de instituições responsáveis pela formação de docentes, com o objetivo de assegurar, de forma mais ampla, que os candidatos ao cargo de professor desenvolvessem os conhecimentos e as habilidades necessárias para a excelência no exercício de sua profissão.

A proposta da agência teve a colaboração do ministério da educação, governos locais, organizações não governamentais, associações profissionais, sindicatos de professores, sindicatos dos formadores de professores, comunidades escolares e dirigentes de escolas. Depois de aprovado pelo governo central, o programa australiano de credenciamento de instituições formadoras passou a ser conduzido de forma descentralizada pelas autoridades estaduais e territoriais do país. ${ }^{53}$ Esse programa fez uso de um conjunto comum de padrões, integrados por meio de três elementos: a) perfil do professor licenciado, composto pelo padrão descrito para o desempenho dos professores australianos no início da carreira ${ }^{54}$ e que

\footnotetext{
${ }^{53}$ A Austrália é formada por seis estados e dois territórios.

${ }^{54}$ De acordo com os padrões australianos de desempenho docente, um professor no nível de licenciado deve ser capaz de elaborar atividades didáticas e avaliativas que atendam aos requisitos de currículo. Além disso, esses profissionais devem demonstrar capacidade de interpretar os dados da avaliação dos alunos para analisar o seu aprendizado, modificando sua prática docente. Sabem também como dar retornos aos alunos, visando
} 
explicitam conhecimentos, habilidades e atributos esperados dos egressos dos cursos de formação inicial; b) padrões de qualidade do curso, ${ }^{55}$ que descrevem características esperadas de formação inicial de professores, de forma a garantir que os padrões de desempenho esperados para os professores sejam alcançados; e c) processo de acreditação, estabelecido nacionalmente para certificar a qualidade dos cursos, incluindo a criação e composição de comissões para avaliar os cursos com base nos critérios estabelecidos para avaliar os cursos e o perfil dos egressos (AUSTRÁLIA, 2011).

O Guia para o Processo de Credenciamento de Cursos de Formação Inicial de Professores da Austrália (AUSTRÁLIA, 2013) tratou de forma bastante específica cada um dos padrões de qualidade considerados e sua forma de comprovação pelas instituições. A análise dessa experiência permitiu a comparação das regras estabelecidas pelo governo australiano para o credenciamento em relação à realidade brasileira, destacando-se: a) a especificação clara do que é um curso de qualidade, assim como o perfil esperado de um professor qualificado, prevendo-se a possibilidade de atualizações dessas especificações sempre que necessário; e b) a necessidade de relatar as evidências ou provas de que os professores licenciados apresentam o perfil estabelecido.

Ainda foi possível observar que o modelo australiano quando comparado ao brasileiro aparentemente não pode ser classificado como ranqueador. Apesar de o primeiro oferecer uma lista de expectativas que exprimem um sentido de qualidade, não foi possível identificar entre os documentos consultados uma hierarquização de características que pudessem exprimir uma realidade como melhor ou pior que a outra, embora fosse possível identificar em quais aspectos, ou não, elas atingiriam a qualidade esperada. $\mathrm{O}$ foco foi o perfil de qualidade traçado a partir de objetivo acordado entre os envolvidos no processo. O trajeto para alcançálos, no entanto, dependeria da criatividade e autonomia de cada instituição.

Por fim, identificou-se que o processo de acreditação australiano pareceu equivaler a um selo de qualidade, garantindo o registro profissional dos egressos dos cursos. Nesse sentido, o processo em foco até permite que cursos não credenciados sejam oferecidos, mas, nesses casos, os professores formados precisam se submeter a um rito específico para auferir

\footnotetext{
melhorar a sua aprendizagem. Além disso, demonstram conhecimento de estratégias práticas para se relacionar com os alunos para garantir um comportamento adequado deles. Sabem como promover o bem-estar e a segurança dos estudantes na escola e garantir o atendimento das exigências legais sobre o currículo. Por fim, entendem a importância de se trabalhar de forma ética, colaborando com colegas, profissionais externos e representantes da comunidade e estão atentos ao incentivo aos pais em prol da aprendizagem de seus filhos.

55 Padrão 1: resultados do curso (alcance do perfil do professor licenciado e de aspectos legais); Padrão 2: desenvolvimento do curso (aspectos gerais da dinâmica do curso); Padrão 3: Participantes do Programa (conhecimentos trazidos pelos alunos); Padrão 4: estrutura do programa e conteúdos; Padrão 5: parcerias escolares (estágios); Padrão 6: infraestrutura do curso; Padrão 7: (auto)avaliação do curso.
} 
seu registro profissional. Adicionalmente, a proposta do programa de credenciamento de cursos de licenciatura visou complementar outros processos de certificação, inclusive o desenvolvido pela agência responsável pela regulação da qualidade da educação superior australiana. $^{56}$

Assim, nas experiências relatadas, observaram-se aspectos que permitiram identificar características que denotam qualidade para o funcionamento desses cursos de formação, as quais estão focadas na profissionalização do egresso e na sua atuação como docente em sala de aula. Considerando essa experiência, aliada à discussão teórica sobre concepção de formação de professores e sobre os documentos legais que orientam a estruturação dos cursos de licenciaturas no Brasil, procurou-se, então, identificar os critérios presentes na avaliação das licenciaturas em pedagogia pelo Sinaes e na oferta desses cursos pelo Parfor, a fim de observar a relação estabelecida entre eles.

\footnotetext{
${ }^{56}$ Tertiary Education Quality and Standards Agency (TEQSA).
} 


\section{CONCEPÇÃO DE QUALIDADE NA FORMAÇÃO DE PEDAGOGOS NO BRASIL}

Neste capítulo, destacaram-se os critérios de qualidade presentes nas avaliações do Sinaes para cursos presenciais de pedagogia, bem como aqueles assumidos pela prática dos cursos dessa mesma natureza sob a chancela do Parfor. Para tanto, consideraram-se as reflexões sobre qualidade como constructo de pesquisa, além das discussões sobre aspectos específicos de qualidade no campo da educação superior e sobre as características apontadas como adequadas para os cursos em questão, realizadas anteriormente no capítulo 2. Essas discussões nortearam os procedimentos metodológicos seguidos, cujos achados permitiram indicar a existência de dois sentidos principais de qualidade na formação de pedagogos - o do Sinaes estruturado e complexo; e o do Parfor não planejado e pulverizado - que, no seu conjunto, pareceram apontar para um significado impreciso, conforme demonstrado a seguir.

\subsection{CAMINHOS PERCORRIDOS PARA A IDENTIFICAÇÃO DA QUALIDADE NA FORMAÇÃO DO PEDAGOGO}

O processo de construção do corpus de pesquisa, a partir do qual se estruturaram as análises apresentadas neste capítulo, originou-se de duas fontes principais de dados: uma ligada ao Sinaes e a outra sob o domínio do Parfor. No caso do Sinaes, destacaram-se do universo de resultados produzidos pelo sistema avaliativo, aqueles referentes aos relatórios de avaliação in loco, ano-base 2008, bem como aos indicadores de qualidade dos cursos de pedagogia presenciais, ano-base 2011. No âmbito do Parfor, delimitou-se a população estudada aos coordenadores de cursos de pedagogia presenciais em atividade no momento da realização do processo de coleta de dados.

Especificamente sobre o Sinaes, a justificativa para a delimitação da população de cursos analisados nesta pesquisa foi posta pela regra definida pela Portaria $n$. $^{\circ} 4$, de 5 de agosto de 2008 (BRASIL, 2008) aliada à necessidade de este estudo comparar os resultados obtidos pelos cursos em visitas avaliativas com aqueles apurados pelo CPC no ciclo avaliativo seguinte. De acordo com a referida portaria, apenas os cursos que não alcançam conceito três (suficiente) no CPC recebem as visitas do Sinaes. Como resultado, encontrou-se uma população de 197 cursos presenciais de pedagogia com CPC 2008 menor que três (representando, potencialmente, o mesmo número de relatórios de avaliação in loco), cujos resultados aferidos nas visitas avaliativas poderiam ser contrastados com aqueles apurados pelos indicadores de qualidade do Sinaes, referentes ao ano-base 2011. 
Uma vez identificados os cursos, foi mapeada a sua evolução em relação ao CPC 2011, bem como outras informações como região geográfica, organização acadêmica e categoria administrativa. O objetivo foi caracterizá-los, de forma a estabelecer critérios para a escolha de uma amostra representativa de relatórios e demais informações documentais a eles relacionadas.

Assim, por meio de ofício disponível no Apêndice E, foi solicitada uma amostra de 40 relatórios de avaliação in loco pertencentes à população de cursos, selecionados a partir de procedimento sistemático com início aleatório (visando manter características da população na amostra). Porém, a realidade empírica terminou por oferecer algumas limitações a essas pretensões: ao se retirar pessoalmente os relatórios na sede do Inep, constatou-se que foram entregues apenas 12 dos 40 relatórios solicitados como amostra, todos eles de IES privadas, conforme dados sistematizados na Tabela 4.

Tabela 4 - Universo e amostra de relatórios de avaliações in loco, por situação do curso.

\begin{tabular}{|c|c|c|c|c|}
\hline Situação do curso $^{1}$ & \multicolumn{2}{|c|}{ Universo } & \multicolumn{2}{|c|}{ Amostra $^{2}$} \\
\hline Total & 197 & $100 \%$ & 12 & $100 \%$ \\
\hline Empenhados & 98 & $50 \%$ & 8 & $66 \%$ \\
\hline Excluídos & 56 & $28 \%$ & 2 & $17 \%$ \\
\hline Recorrentes & 43 & $22 \%$ & 2 & $17 \%$ \\
\hline
\end{tabular}

Fonte: Elaboração da autora com base em dados divulgados pelo Inep (INEP, [2009?a]; [2013]).

${ }^{1}$ Indica a evolução, exclusão ou manutenção da qualidade dos cursos em função dos resultados obtidos no CPC 2008 em comparação ao CPC 2011: empenhado - cursos que melhoraram de nota; excluídos - cursos com CPC < 3 em 2008 e que ficaram sem conceito (s/c) ou saíram do sistema em 2011; recorrentes - cursos que mantiveram CPC $<3$ em 2011.

${ }^{2}$ O Inep enviou um total de 17 (dezessete) relatórios de visitas avaliativas. Porém, cinco desses relatórios precisaram ser descartados, pois se referiam a cursos localizados em cidades diferentes às dos cursos da amostra ou não se referiam a uma avaliação de renovação de reconhecimento de curso. Os relatórios foram codificados em função da amostra de 40 casos inicialmente escolhidos, tendo sido numerados de 1 a 40 . Nesse sentido, na análise dos dados puderam-se encontrar cursos codificados com numeração superior a 12, número de casos total da amostra.

Segundo o Inep, dos 197 cursos com CPC menor que três em 2008, parte não foi visitada em razão de IES estaduais e municipais não serem reguladas com base nas avaliações do Sinaes, submetendo-se apenas em caráter voluntário ao sistema. ${ }^{57}$ Além disso, mesmo entre as instituições federais e privadas, muitas não foram avaliadas in loco, em função de procedimentos fixados pelo MEC, que definiu ser de responsabilidade das IES a solicitação

57 Esse procedimento permitiu considerar que a participação voluntária de IES estaduais e municipais no Sinaes está restrita ao Enade e, por consequência, ao CPC. As visitas, mesmo estando previstas como complementação desse processo avaliativo, na prática, estão sendo usadas como regulatórias. 
da visita, sem prever a possibilidade de que elas ocorressem ex-officio, para os casos de inobservância dessa responsabilidade.

Ante a realidade empírica e considerando que a quantidade limitada de casos disponíveis poderia fragilizar a análise dos dados, utilizou-se a saturação teórica (FONTANELLA; RICAS; TURATO, 2008; FONTANELLA ET AL, 2011) para validar o fechamento da amostra de relatórios das avaliações in loco disponíveis. O resultado encontrado foi sistematizado na Tabela 5.

Tabela 5 - Distribuição de frequência de enunciados referentes à dimensão organização didáticopedagógica, presentes nos relatórios de avaliação in loco.

\begin{tabular}{|c|c|c|c|c|c|c|c|c|c|c|c|c|c|}
\hline \multirow{2}{*}{ Aspectos analisados } & \multicolumn{12}{|c|}{ Relatório de Avaliação in loco $^{I}$} & \multirow{2}{*}{$\begin{array}{c}\text { Total de } \\
\text { recorrências }\end{array}$} \\
\hline & 3 & 5 & 10 & 6 & 8 & 11 & 12 & 13 & 14 & 15 & 16 & 35 & \\
\hline Tratamento do conteúdos & $\mathrm{X}$ & $\mathrm{x}$ & $\mathrm{x}$ & $\mathrm{x}$ & $\mathrm{x}$ & $\mathrm{x}$ & $\mathrm{x}$ & $\mathrm{x}$ & $\mathrm{x}$ & $\mathrm{x}$ & $\mathrm{x}$ & $\mathrm{x}$ & 12 \\
\hline Legalidade & $\mathrm{X}$ & $\mathrm{x}$ & $\mathrm{x}$ & $\mathrm{x}$ & $\mathrm{x}$ & $\mathrm{x}$ & $\mathrm{x}$ & $\mathrm{x}$ & $\mathrm{x}$ & $\mathrm{x}$ & $\mathrm{x}$ & $\mathrm{x}$ & 12 \\
\hline Autoavaliação & $\mathrm{X}$ & $\mathrm{x}$ & $\mathrm{x}$ & $\mathrm{x}$ & $\mathrm{x}$ & $\mathrm{x}$ & $\mathrm{x}$ & $\mathrm{x}$ & $\mathrm{x}$ & $\mathrm{x}$ & $\mathrm{x}$ & & 11 \\
\hline Gestão do curso & $\mathrm{X}$ & $\mathrm{x}$ & & $\mathrm{x}$ & $\mathrm{x}$ & & $\mathrm{x}$ & $\mathrm{x}$ & $\mathrm{x}$ & $\mathrm{x}$ & $\mathrm{x}$ & $\mathrm{x}$ & 10 \\
\hline Estágio curricular & $\mathrm{X}$ & & $\mathrm{x}$ & $\mathrm{x}$ & $\mathrm{x}$ & $\mathrm{x}$ & $\mathrm{x}$ & $\mathrm{x}$ & $\mathrm{x}$ & $\mathrm{x}$ & $\mathrm{x}$ & $\mathrm{x}$ & 11 \\
\hline $\begin{array}{l}\text { Prática de docência e gestão } \\
\text { educacional }\end{array}$ & $\mathrm{X}$ & & $\mathrm{x}$ & $\mathrm{x}$ & $\mathrm{x}$ & $\mathrm{x}$ & $\mathrm{x}$ & $\mathrm{x}$ & $\mathrm{x}$ & $\mathrm{x}$ & $\mathrm{x}$ & $\mathrm{x}$ & 11 \\
\hline Atividades complementares & $\mathrm{X}$ & & $\mathrm{x}$ & $\mathrm{x}$ & $\mathrm{x}$ & $\mathrm{x}$ & $\mathrm{x}$ & $\mathrm{x}$ & $\mathrm{x}$ & $\mathrm{x}$ & $\mathrm{x}$ & $\mathrm{x}$ & 11 \\
\hline Perfil do egresso & $\mathrm{X}$ & & $\mathrm{x}$ & $\mathrm{x}$ & $\mathrm{x}$ & $\mathrm{x}$ & $\mathrm{x}$ & $\mathrm{x}$ & & & $\mathrm{x}$ & & 8 \\
\hline Tratamento da pesquisa & $\mathrm{X}$ & & $\mathrm{x}$ & $\mathrm{x}$ & & & $\mathrm{x}$ & $\mathrm{x}$ & & & $\mathrm{x}$ & $\mathrm{x}$ & 7 \\
\hline Concepção de curso & $\mathrm{X}$ & & & & $\mathrm{x}$ & & $\mathrm{x}$ & & $\mathrm{x}$ & $\mathrm{x}$ & $\mathrm{x}$ & & 6 \\
\hline Desenvolvimento cultural do aluno & $\mathrm{X}$ & & & & & & & & & & & $\mathrm{x}$ & 2 \\
\hline Modalidades de ensino & $\mathrm{X}$ & & & & & & & & & & & & 1 \\
\hline Cuidados com os alunos & $\mathrm{X}$ & & & & & & & & & & & $\mathrm{x}$ & 2 \\
\hline $\begin{array}{l}\text { Tecnologias de Informação e } \\
\text { Comunicação }\end{array}$ & & $X$ & & & & $\mathrm{x}$ & $\mathrm{x}$ & $\mathrm{x}$ & & & & & 4 \\
\hline Parcerias para estágio & & & $\mathrm{X}$ & & & & & & & & $\mathrm{x}$ & & 2 \\
\hline Total de novos aspectos & 13 & 1 & 1 & $\mathbf{0}$ & $\mathbf{0}$ & $\mathbf{0}$ & $\mathbf{0}$ & $\mathbf{0}$ & $\mathbf{0}$ & $\mathbf{0}$ & $\mathbf{0}$ & $\mathbf{0}$ & - \\
\hline
\end{tabular}

Fonte: Elaborado pela autora com base nos dados da pesquisa

Nota: X: novo tipo de aspecto; $x$ : recorrências.

1 Numeração recebida no processo de organização do rol de casos da amostra, sem compromisso com a sequencialidade numérica dos casos que efetivamente participaram da amostra.

Conforme demonstrado, a saturação teórica indicou que os dados analisados eram suficientes para o desenvolvimento das reflexões teóricas previstas para a pesquisa. A 
sistematização dos dados permitiu identificar que já a partir da terceira entrevista analisada não houve ocorrência de novos temas ou aspectos de avaliação da dimensão organização didático-pedagógica, que indicassem a necessidade de novas coletas de relatórios. Portanto, optou-se por fechar a amostra com os casos disponíveis.

No caso do Parfor, que congregou os casos de uma segunda fonte de informações para os dados analisados neste capítulo, identificou-se como população o conjunto dos coordenadores de cursos presenciais de pedagogia oferecidos no âmbito do Programa, que estivessem ativos no Sistema Geral de Bolsas (SGB) da Capes em julho/2013 - momento em que se iniciou o processo de coleta de dados da pesquisa. Nessa população, sistematizada na Tabela 6, identificaram-se 59 coordenadores aptos a participar desta pesquisa.

Tabela 6 - Número de coordenadores de cursos de pedagogia, primeira licenciatura, do Parfor Presencial ativos no Sistema Geral de Bolsas (SGB) da Capes - julho/2013.

\begin{tabular}{|c|c|c|c|c|c|c|c|c|c|c|}
\hline \multirow[t]{2}{*}{ Região } & \multicolumn{2}{|c|}{ Municipal } & \multicolumn{2}{|c|}{ Estadual } & \multicolumn{2}{|c|}{ Federal } & \multicolumn{2}{|c|}{ Privada } & \multicolumn{2}{|c|}{ Total } \\
\hline & $\mathrm{N}$ & $\%$ & $\mathrm{~N}$ & $\%$ & $\mathrm{~N}$ & $\%$ & $\mathrm{~N}$ & $\%$ & $\mathrm{~N}$ & $\%$ \\
\hline Total & 1 & $100 \%$ & 19 & $100 \%$ & 17 & $100 \%$ & 22 & $100 \%$ & 59 & $100 \%$ \\
\hline Centro-Oeste & - & - & - & - & 1 & $6 \%$ & - & - & 1 & $2 \%$ \\
\hline Nordeste & - & - & 11 & $58 \%$ & 5 & $29 \%$ & - & - & 16 & $27 \%$ \\
\hline Norte & - & - & 3 & $16 \%$ & 7 & $41 \%$ & - & - & 10 & $17 \%$ \\
\hline Sudeste & 1 & $100 \%$ & 2 & $11 \%$ & 1 & $6 \%$ & 16 & $73 \%$ & 20 & $34 \%$ \\
\hline Sul & - & - & 3 & $16 \%$ & 3 & $18 \%$ & 6 & $27 \%$ & 12 & $20 \%$ \\
\hline
\end{tabular}

Fonte: Diretoria de Educação Básica/Capes (SGB).

Nesses dados, chamou a atenção a pequena participação da Região Centro-Oeste, que congregou apenas $2 \%$ desses indivíduos. Além disso, destacou-se o fato que mais de um terço desses coordenadores apresentaram-se vinculados a IES privadas sem fins lucrativos, bem como sua concentração na Região Sudeste (73\%).

No âmbito dessa população de coordenadores de curso, foram selecionados dois tipos de amostras. A primeira foi escolhida para a realização de pré-teste do instrumento piloto de coleta de dados (Apêndice $\mathrm{H}$ ), a fim de se observar de forma contextualizada tanto o formato de aplicação previsto - entrevistas via telefone ou via conferência web - quanto a pertinência dos dados levantados pelas questões. Já o segundo tipo de amostra se propôs à realização da 
pesquisa propriamente dita, na qual foi aplicado o roteiro definitivo de entrevistas (Apêndice D).

A amostra piloto foi selecionada tendo por base os seguintes critérios intencionais: representação de cada uma das dependências administrativas consideradas (estadual, federal e privada); presença das duas regiões onde estão mais concentrados os cursos (Nordeste e Sudeste); presença de diferentes unidades da federação; e concordância do coordenador em participar da entrevista. De acordo com Babbie (1995), escolher intencionalmente uma amostra é popular, fácil e oferece baixo custo, adequando-se ao proposto no piloto. Por isso, com base nesses critérios foram entrevistados três coordenadores de cursos de pedagogia, sendo dois da Região Nordeste - um de IES federal e outro de IES estadual - e um coordenador da Região Sudeste de IES privada.

Já na escolha da segunda amostra de coordenadores de curso - utilizada para as análises previstas na pesquisa -, observou-se prioritariamente a sua aproximação da realidade concreta. Para tanto, procurou-se preservar as variações presentes na população de coordenadores para manter a amostra representativa e permitir descrições úteis sobre ela, conforme recomendou Babbie (1995).

Considerando a abordagem qualitativa da pesquisa, não se encontrou nos manuais de metodologia que tratam do tema uma orientação sobre o tamanho ideal de uma amostra. Assim, estipulou-se em 18 o número de coordenadores a ser entrevistados, representando cerca de $30 \%$ dessa população. Esse número de casos considerou, ainda, o respeito às características institucionais e regionais dos cursos presenciais de pedagogia do Parfor, bem como a necessidade de utilização desses estratos para a escolha dos coordenadores entrevistados. No processo de escolha dessa amostra, utilizou-se procedimento sistemático de início aleatório, realizando-se ordenamento alfabético da moldura amostral a partir da região geográfica, da unidade da federação e da categoria administrativa (estadual, federal e privada) da IES de sua atuação. Então, após serem excluídos os participantes da primeira amostra (piloto), os coordenadores foram numerados em ordem crescente, tendo sido sorteado um número inicial, a partir do qual se retirou o primeiro sujeito da amostra. Na sequência, utilizou-se o intervalo de amostragem igual a três para escolher os demais sujeitos. Esse intervalo foi estabelecido aproximando-se o resultado da divisão do número total de cursos da população (59) pelo número total de cursos definidos para a amostra (18). Entre esses selecionados, houve a necessidade de substituição de quatro sujeitos que não concordaram em dar a entrevista, sendo substituídos por aqueles que o sucediam pela ordem da moldura amostral. Após a coleta, na fase de tratamento e análise, uma das entrevistas precisou ser 
eliminada por representar um curso de segunda licenciatura, apesar de os registros informados pela Capes apontarem-no como um curso de primeira licenciatura. Como se constatou que a diminuição de um sujeito da amostra não comprometeu a consistência dos resultados encontrados, optou-se por não substituí-lo.

A amostra definitiva de coordenadores entrevistados foi fechada em 17 sujeitos, os quais mantiveram características institucionais e geográficas muito próximas às da população, Conforme pôde ser observado no Gráfico 7. Ressaltou-se, ainda, que para permitir a representatividade da amostra, o processo de escolha aleatória levou à seleção de um mesmo número de coordenadores de pedagogia entre as regiões Nordeste e Sul, embora a primeira conte com um número maior de coordenadores na população pesquisada.

Gráfico 7 - Estrutura da amostra de coordenadores do curso de pedagogia do Parfor Presencial, categoria administrativa e região - julho/2013.

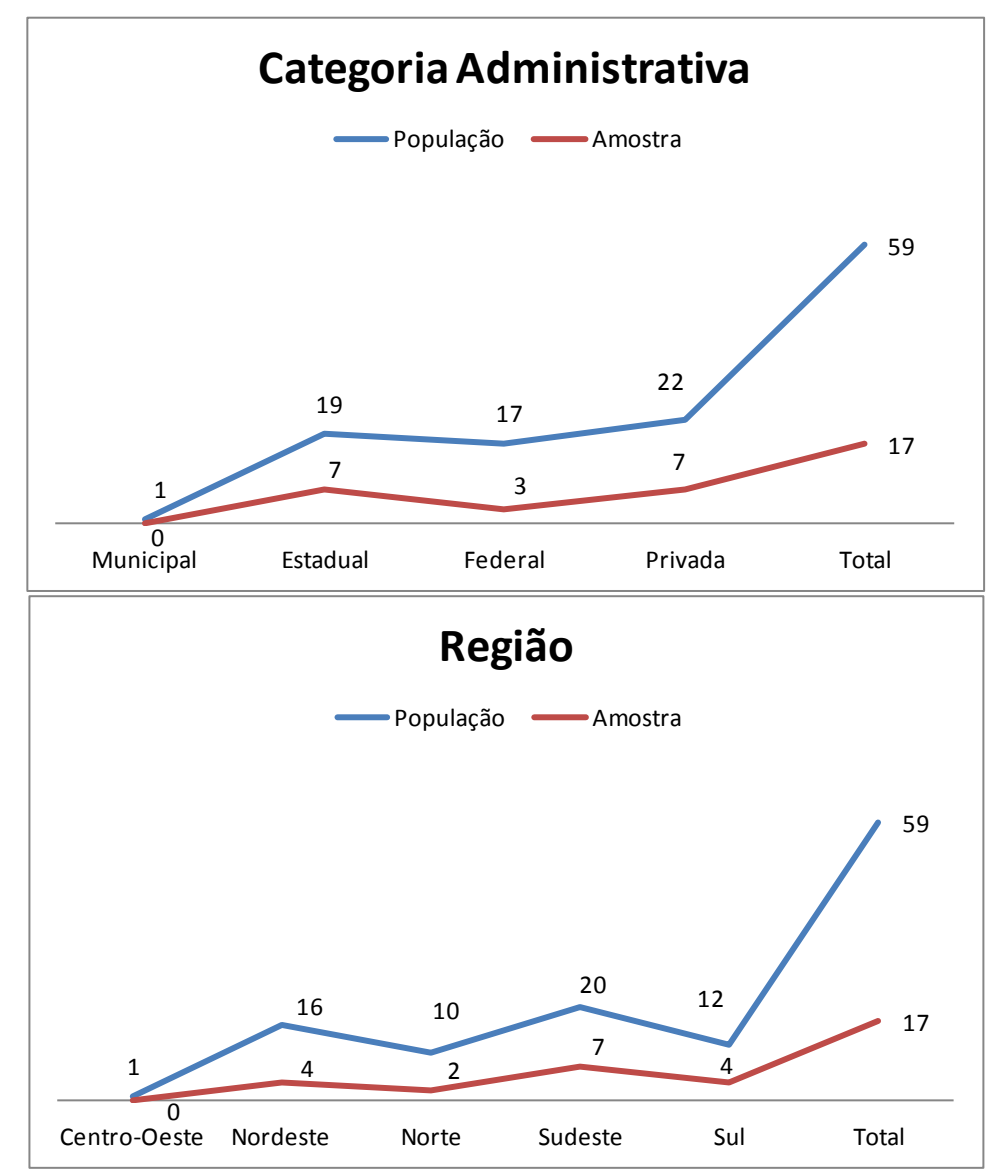

Fonte: Elaborado pela autora com base em dados fornecidos pela Diretoria de Educação Básica da Capes.

Em relação à representatividade da amostra em termos dos CPCs apresentados pelos cursos dos coordenadores selecionados, os dados disponíveis para essa análise se mostraram pouco confiáveis. Na base de dados disponibilizada pela Capes inexistiam informações sobre 
o cadastro do curso no Inep. Com isso, as tentativas de identificação das turmas do Parfor nos indicadores de resultados exarados pelo Sinaes foram inviabilizadas pela inexistência de campos-chave que permitissem esse cruzamento. As diversas tentativas realizadas nesse intento foram frustradas pela perspectiva de a Capes registrar apenas os municípios beneficiados pelas turmas do Parfor, atrelando-as à instituição de educação superior responsável, sem anotar, no entanto, o campus responsável pela oferta.

Assim, considerando o processo de coleta de dados para classificar pesquisas nos termos definidos por Gil (1999), pôde-se considerar o presente relato como: i) estudo de campo, com base nas informações fornecidas, por meio de entrevistas, pelos coordenadores acadêmicos dos cursos presenciais de pedagogia e por membros do CTC-EB; e ii) pesquisa documental, ao buscar dados nos relatórios e documentos gerados pelo Sinaes sobre a qualidade dos cursos de pedagogia

No que se refere à opção de utilizar a entrevista como instrumento de coleta da pesquisa de campo foi justificada pela necessidade de identificação das características consideradas pelos coordenadores dos cursos de pedagogia do Parfor Presencial como necessárias à oferta com qualidade da formação de professores dos anos iniciais da educação básica. Conforme destacou Cruz Neto (2010), a entrevista viabiliza a construção de informações sobre um objeto de pesquisa de forma pertinente e integrada ao propósito de investigação. Além disso, o roteiro adotado passou por procedimento prévio de testagem, visando ampliar sua aderência ao objeto desta pesquisa, conforme relatado no Apêndice F.

Em relação ao tratamento e análise dos dados, como já declarado na introdução, optou-se pela hermenêutica como técnica de análise de material qualitativo. Segundo Minayo (2013), a hermenêutica pode ser vista como a arte da compreensão de textos, tomados no seu sentido mais abrangente como formas de comunicação humana (biografias, entrevistas, documento, etc.). Dentro dessa proposta, buscou-se inserir os dados coletados nos conceitos teóricos e trajetórias históricas que contextualizaram o objeto de estudo. Nesse processo, foram utilizadas as etapas sugeridas pela autora consultada, com adaptações para a realidade em foco, a saber:

A) Relatórios de avaliação de cursos in loco produzidos pelo Sinaes:

i) codificação dos relatórios a partir da numeração progressiva de identificação que eles receberam inicialmente, quando da montagem do rol de casos selecionados na amostra;

ii) leitura flutuante, permitindo aproximação aos documentos a serem analisados por meio do levantamento das primeiras impressões sobre o seu conteúdo; 
iii) preparação de uma planilha eletrônica com o código de identificação dos documentos e as variáveis de contexto dos cursos (características das instituições, indicadores de qualidade do Sinaes, etc.), acrescida de colunas identificadoras de unidades de sentido (categorias analíticas e empíricas, bem como seus desdobramentos em indicadores);

iv) classificação dos trechos mais relevantes por unidade de sentido, ao mesmo tempo que se acrescentou as categorias empíricas como desdobramentos, ou não, das categorias analíticas;

v) leitura transversal dos trechos classificados nas colunas, contemplando as categorias analíticas e empíricas, destacando-se convergências, divergências e demais aspectos de cada subconjunto (filtros de acordo com as variáveis de contexto constante da planilha) em relação a sua totalidade. Essa leitura permitiu que as unidades de sentido fossem contrastadas entre si;

vi) análise final, tomada dialeticamente como ponto de partida e de chegada, na qual as leituras flutuante e transversal do material se organizaram no texto apresentado neste relatório. Essa etapa implicou várias idas e vindas ao conjunto dos dados, na sua classificação e no próprio processo de análise.

B) Entrevistas dos coordenadores de cursos de pedagogia do Parfor:

i) transcrição das entrevistas gravadas, com a supressão de repetições ou expressões características da expressão oral, bem como a introdução de referências sobre o que ou de quem se falou, quando necessário dotar o depoimento de maior clareza;

ii) codificação do texto da entrevista com letras representativas das IES responsáveis pelo curso;

iii) leitura flutuante, conforme já indicado anteriormente;

iv) preparação de uma planilha eletrônica com código do texto da entrevista, variáveis de contexto dos cursos e dos coordenadores (formação acadêmica, tempo e tipos de experiências de coordenação, etc.), acrescida de colunas representativas das unidades de sentido, seguida dos demais passos previstos de iv) a vi) do item A.

Como resultado do percurso percorrido na construção e análise do corpus desta pesquisa em torno dos critérios de qualidade do Sinaes e do Parfor para cursos de pedagogia, apresentam-se, nas seções que seguem, os seus principais achados. 


\subsection{CRITÉRIOS DE QUALIDADE USADOS PELO SINAES PARA AVALIAR AS LICENCIATURAS PRESENCIAIS EM PEDAGOGIA}

O sentido de qualidade indicado pelos critérios utilizados pelo Sinaes para avaliar a oferta de cursos de graduação, em geral, e a oferta das licenciaturas em pedagogia, de uma forma específica, pôde ser evidenciado a partir de dois instrumentos básicos: as avaliações in loco de cursos e o CPC. Visando a uma aproximação mais orgânica a eles, partiu-se da caracterização dos indicadores e parâmetros presentes nas avaliações in loco para, em seguida, destacar suas aproximações e afastamentos em relação ao CPC. Ao final, buscou-se sintetizar os aspectos assumidos pelo sistema avaliativo como adequados para a formação de professores da educação infantil e dos anos iniciais da educação básica.

\subsubsection{Indicadores e parâmetros das avaliações in loco}

Os indicadores e parâmetros que formam os critérios para a avaliação in loco dos cursos de graduação adotados pelo Sinaes, inclusive os de pedagogia, estão contidos no Instrumento de Avaliação de Cursos de Graduação Presencial e a Distância (INEP, 2012a). Esse instrumento definiu três dimensões para a aferição da qualidade do curso que participam do ciclo: 1) - organização didático-pedagógica; 2) - corpo docente e tutorial e 3) infraestrutura. Os pesos dessas dimensões são diferenciados entre cursos novos (processos de autorização e reconhecimento) e aqueles já integrantes do ciclo avaliativo (processos de renovação de reconhecimento). No caso das avaliações do ciclo, o peso maior cabe à organização didático-pedagógica (peso 40), seguidas das outras duas com peso 30 cada uma. Entre os indicadores que compõem cada uma das dimensões, não há pesos diferenciados. Em relação à escala de notas aplicadas no processo avaliativo, o Sinaes considera: nota um qualidade inexistente; nota dois - qualidade insuficiente; nota três - qualidade suficiente; nota quatro - qualidade muito boa; e nota cinco - qualidade excelente.

Dos 63 itens que estruturavam o instrumento, apenas $35 \%(\mathrm{n}=22)$ puderam ser considerados indicadores, visto que apenas estes, nos termos assumidos na subseção 2.2, permitiram caracterizar a realidade dos cursos por meio de uma escala de medidas sistematizada. Como quatro deles se aplicaram exclusivamente aos cursos de medicina, restaram, então, 18 itens do referido instrumento que foram considerados como indicadores para as análises aqui realizadas. Os demais itens que compuseram o instrumento de avaliação in loco do Sinaes tiveram a escala de medidas substituída pela análise subjetiva dos avaliadores sobre a realidade, sem que qualquer sistematização desse julgamento pudesse ser 
identificada de forma explícita. Assim, dos 18 indicadores aplicáveis aos cursos de pedagogia pertencentes ao instrumento de avaliação in loco vigente, $83 \%(n=15)$ estavam concentrados na dimensão 2 - corpo docente e tutoria e $17 \%(n=3)$ na dimensão 3 - infraestrutura. Nenhum indicador foi identificado na dimensão 1 - organização didático-pedagógica.

Com base nesse panorama, foi possível observar que, nas avaliações in loco do Sinaes, um curso de pedagogia tem qualidade (nota três ou superior) na dimensão 2 - corpo docente e tutorial, quando:

a) o(a) coordenador(a) possui experiência em cursos a distância maior ou igual a dois anos (apenas aplicável no caso dos cursos a distância);

b) o(a) coordenador(a) possui experiência profissional de magistério superior e de gestão acadêmica que somadas é maior ou igual a quatro anos, sendo, no mínimo, um ano de magistério superior;

c) o regime de trabalho previsto/implantado do(a) coordenador(a) é de tempo parcial ou integral e a relação entre o número de vagas anuais pretendidas/autorizadas e as horas semanais dedicadas à coordenação deve ser menor que 20;

d) a carga horária prevista/implantada para o(a) coordenador(a) do curso é maior ou igual a 15 horas semanais dedicadas totalmente à coordenação;

e) o percentual dos docentes do curso com titulação obtida em programas de pós-graduação stricto sensu é maior ou igual a $30 \%$;

f) o percentual de doutores do curso é maior que $10 \%$;

g) o percentual do corpo docente previsto/efetivo com regime de trabalho de tempo parcial ou integral é maior ou igual a $33 \%$;

h) um contingente maior ou igual a $40 \%$ do corpo docente previsto/efetivo possui experiência profissional (excluída as atividades no magistério superior) de, pelo menos, dois anos em bacharelados/licenciaturas;

i) um contingente maior ou igual a $30 \%$ do corpo docente previsto/efetivo tem, pelo menos, três anos de experiência no exercício da docência na educação básica;

j) um contingente maior ou igual a $40 \%$ do corpo docente previsto/efetivo possui experiência de magistério superior de, pelo menos, três anos para bacharelados/licenciaturas;

k) a média entre o número de docentes do curso (equivalentes $40 \mathrm{~h}$ ) e o número de vagas previstas/implantadas é de um docente para 150 vagas ou menos;

1) pelo menos $50 \%$ dos docentes têm quatro ou mais produções nos últimos três anos; 
m) todos os tutores previstos/efetivos são graduados na área (apenas aplicável no caso dos cursos a distância);

n) o percentual de tutores do curso previstos/efetivos que possui experiência mínima de três anos em cursos a distância é maior ou igual a 50\% (apenas aplicável no caso dos cursos a distância);

o) a relação entre o número de estudantes e o total de docentes mais tutores (presenciais e a distância) previstos/contratados é menor ou igual a 50 (apenas aplicável no caso dos cursos a distância).

No que se refere à dimensão 3 - infraestrutura, o Sinaes assumiu que os cursos de pedagogia tem qualidade (nota três ou superior), quando:

a) o acervo da bibliografia básica, com no mínimo três títulos por unidade curricular, está disponível na proporção média de um exemplar para a faixa de menos de 15 vagas anuais pretendidas/autorizadas, de cada uma das unidades curriculares, de todos os cursos que efetivamente utilizam o acervo, além de estar informatizado e tombado junto ao patrimônio da IES;

b) o acervo da bibliografia complementar possui, pelo menos, três títulos por unidade curricular, com dois exemplares de cada título ou com acesso virtual;

c) há assinatura/acesso de periódicos especializados, indexados e correntes, sob a forma impressa ou virtual, maior ou igual a dez títulos distribuídos entre as principais áreas do curso, a maioria deles com acervo atualizado em relação aos últimos três anos.

Analisando essas duas primeiras dimensões, pareceu haver certa mecanização na definição desses critérios - que os deixaram vazios de significado -, uma vez que não foi possível estabelecer um paralelo entre o grau de qualidade apurada e as oportunidades de aprendizagem viabilizadas por eles aos alunos. Exemplo disso foi a exigência de certa quantidade de número de exemplares de livros da bibliografia básica e complementar no acervo tombado da biblioteca, sem que se estabelecesse uma relação entre o número de alunos matriculados nas disciplinas que fazem uso dos títulos, mas, sim, uma projeção de matrículas. Adicionalmente, pareceu pouco provável que no contexto de uma visita avaliativa seria possível aos avaliadores identificarem que uma dada referência bibliográfica estaria atendendo a mais de uma disciplina, muito menos em cursos diferentes. Além disso, esses critérios não levaram em conta a possibilidade de muitos livros e artigos científicos estarem disponíveis na Internet para download, o que contrariaria a obrigatoriedade de existência de acervo físico em alguns casos. Para não passar em branco exemplos da dimensão corpo docente que remeteram à simples mecanização de parâmetros avaliativos, pôde-se citar, ainda, 
a exigência de experiência para o corpo docente sem garantias de que essa experiência se reverteria, necessariamente, em aperfeiçoamento de sua prática como docente formador.

Por fim, no que se referiu à dimensão 1 - organização didático-pedagógica, que possui maior peso no instrumento de visita utilizado para a avaliação do ciclo, a falta de sistematização de escalas de medidas e, por consequência de indicadores e parâmetros, pôde ser evidenciada a partir dos registros constantes dos próprios instrumentos preenchidos, quando estes assumiram a forma de relatório da avaliação in loco. Nesses relatórios, os critérios de qualidade relativos à dimensão em foco - ou a falta deles - foram sistematizados com base no marco teórico discutido na subseção 2.2 por meio de quatro dimensões: a) concepções de formação docente; b) perfil do pedagogo; c) estrutura do curso; e d) outros aspectos, emergidos principalmente do comportamento dos dados em confrontação com as experiências internacionais, a seguir detalhadas.

\subsubsection{Concepções de formação docente}

A partir dos dados analisados, foi possível observar que as concepções de formação de professores mapeadas nesta pesquisa não foram utilizadas explicitamente pelo Sinaes para distinguir a qualidade das licenciaturas em pedagogia. Tais concepções - agrupadas por Araújo (2009) meio das racionalidades técnicas, crítica e prática, além da perspectiva plural proposta por (Rios, 2010) - foram identificadas de forma indireta em cerca de metade dos relatos analisados, conforme pode ser observado nos trechos transcritos a seguir, que exemplificam tais referências, respectivamente, à racionalidade prática e à racionalidade crítica:

[...] processo reflexivo de construção do conhecimento essencial à formação do aluno (Relatório sobre o curso 8).

[...] os objetivos estão sendo gerados e discutidos através da reflexão crítica, com o intuito de entender e intervir na realidade brasileira (Relatório sobre o curso 14).

De forma mais frequente, apareceram referências à perspectiva plural como concepção de um curso com qualidade, no sentido muito próximo àquele definido por Rios (2010), que alertou para a possível indissociabilidade das dimensões denominadas neste trabalho de racionalidade técnica, racionalidade prática e racionalidade crítica, conforme transcrito: 
[...] formar profissionais reflexivos, críticos e atuantes como cidadãos (Relatório sobre o curso 15$)$.

[...] formar profissionais reflexivos e críticos (Relatório sobre o curso 3).

[...] contribuir para a formação de profissionais altamente qualificados, com visão crítica, criativa e inovadora [...] (Relatório sobre o curso 12).

Porém, não foi possível encontrar nos dados uma tendência de dominância de qualquer uma das abordagens categorizadas como um aspecto determinante para a qualidade do curso, seguindo-se o que foi registrado pelos avaliadores. Além disso, embora na realidade empírica dos cursos de pedagogia se tenha identificado um predomínio de uma concepção de formação mais totalizante, fugindo à visão polarizada das racionalidades técnica, crítica ou prática, discutidas por Araújo (2009), isso não pareceu significar que tal concepção seja considerada como melhor ou pior pelos avaliadores do Sinaes.

Nesse sentido, chamou a atenção que, apesar da intensa discussão teórica sobre concepções de formação do professor e de sua relação direta com a concepção de qualidade desses cursos, tal aspecto e suas categorias não tenham despontado como um indicador relevante para a avaliação da qualidade dos cursos. Os dados evidenciaram que as discussões em torno de princípios orientadores do processo formativo do pedagogo - sejam eles enfeixados em ideias como as de inovação, formação teórica, inserção política, competência técnica, tomadas separadamente ou reunidas por diversos arranjos entre elas - não fizeram parte estrita dos critérios de qualidade presentes no sistema avaliativo. Assim, diante do isomorfismo do Sinaes, a concepção formativa dos cursos terminou por ser pouco destacada pelos avaliadores em suas análises sobre a qualidade dos cursos de pedagogia.

\subsubsection{Perfil do pedagogo}

A partir dos relatórios produzidos pelo Sinaes, referentes às avaliações de cursos de pedagogia in loco, procurou-se identificar como o perfil do egresso repercutiu na atribuição de notas referentes à dimensão organização didático-pedagógica dos cursos avaliados. $\mathrm{O}$ primeiro dado que chamou a atenção foi o fato de que os registros sobre esse aspecto atingiram apenas metade dos relatórios da amostra. $\mathrm{O}$ segundo foi que, quando apareceram os registros sobre perfil, eles pouco evidenciaram as características esperadas para o egresso do curso em foco, conforme exemplos a seguir:

[os alunos] terão o perfil do egresso qualificado para exercer a função de professor (Relatório sobre o curso 13). 
[...] o pedagogo formado [...] é um profissional que atua em várias instâncias da prática educativa, direta ou indiretamente ligadas à organização e aos processos de transmissão e assimilação ativa de saberes e de modos de ação [...] (Relatório sobre o curso 12).

Outra variante encontrada nos relatórios para a descrição do perfil do egresso era a definição conceitual desse perfil, previsto no art. $4 .^{\circ}$ das DCN do curso (BRASIL, 2006b), sem caracterizar a singularidade do projeto pedagógico do curso como presente em trecho do relatório sobre o curso 6: "[...] professor da educação infantil e anos iniciais do ensino fundamental e gestão escolar em espaços escolares e não escolares."

O terceiro dado que chamou a atenção foi que em nenhum dos relatórios da amostra foram encontrados itens relativos ao perfil do pedagogo que pudessem estabelecer conexão com as competências definidas pela Prova Nacional de Concurso para Ingresso na Carreira Docente, estabelecida pela Portaria Normativa n. ${ }^{\circ}$, de 2 de março de 2011 e em elaboração pelo Inep, para subsidiar a admissão de docentes para a educação básica no âmbito dos Estados, do Distrito Federal e dos Municípios (BRASIL, 2011a).

Esse fato, em comparação com a experiência internacional relatada na subseção 2.2.3, destacou a carência brasileira na promoção de uma interconexão entre suas políticas públicas, no que diz respeito à qualidade esperada da ação do professor da educação básica. No exemplo da Austrália, os critérios utilizados para a avaliação de desempenho de docentes da educação básica recém-admitidos são os mesmos utilizados para avaliar os cursos de formação, considerando os seus resultados em torno da formação do perfil especificado. Tal complementaridade pareceu mostrar a harmonia entre esforços que, mesmo empreendidos individualmente, convergiram para um mesmo objetivo, reforçando-se mutuamente.

No caso brasileiro, a prova docente, que nasceu com o objetivo de avaliar competências dos candidatos ao cargo de professor, teve o mérito de explicitar um perfil profissional de professores para a educação infantil e anos iniciais do ensino fundamental. Para tanto, considerou três dimensões, a saber: Dimensão A - Profissão Docente e Cidadania, que congrega competências do professor em torno da compreensão de aspectos culturais, sociais, ambientais, políticos, econômicos e tecnológicos da sociedade e suas interfaces com a educação, atuação em situações do cotidiano escolar com base na legislação vigente e na promoção de ações, no âmbito da comunidade escolar, com vistas à inclusão e ao respeito às diversidades; Dimensão B - Trabalho Pedagógico, que envolve o planejamento do trabalho pedagógico para orientar os processos de ensino e aprendizagem, o uso de estratégias e recursos pedagógicos diversificados para alcançar os objetivos pedagógicos e de 
procedimentos de acompanhamento e avaliação de forma articulada e coerente com as estratégias pedagógicas; e Dimensão C - Domínio dos Conteúdos Curriculares, que engloba a comunicação com coerência e coesão por meio de texto escrito, a compreensão e utilização de conteúdos curriculares, apresentados em diferentes linguagens, o emprego de conhecimento referente aos conteúdos curriculares para resolver situações-problema e a articulação de conhecimentos referentes aos diferentes conteúdos curriculares para analisar fenômenos do mundo natural e social. Nenhuma dessas dimensões, no entanto, inspirou os avaliadores do Sinaes em torno da análise do perfil do egresso associado a elas, mesmo estando em discussão durante o período de realização das visitas.

Ante esse fato, tornou-se prudente ressaltar que a prova em discussão tem um caráter de seletividade para ingresso na carreira docente, funcionando como um concurso público. Dessa forma, não há como desconsiderar que o perfil traçado para a seleção do futuro professor da educação infantil e dos anos iniciais do ensino fundamental das redes públicas de educação básica traz elementos que influenciam diretamente os cursos de formação. Os conhecimentos aferidos pela Prova Docente e, porque não dizer, pelo próprio Enade, terminam por contribuir diretamente no perfil dos professores a serem formados. Apesar disso, a relação entre os três instrumentos (avaliações de curso in loco, Enade e prova docente) no que diz respeito ao perfil do pedagogo ainda não está posta, na medida em que o mesmo órgão que produz os três processos avaliativos não tem explicitado os pontos de afinidade nem de divergência entre eles.

Por fim, constatou-se que as evidências levantadas a partir dos dados coletados pareceram indicar certa ambiguidade na aferição de qualidade trazida pelo Sinaes. Apesar de o perfil do pedagogo não contar com um olhar apurado do avaliador (tendo em vista que não foi descrito/analisado nos relatórios de avaliação constantes da amostra), é a partir dele que se busca a coerência do projeto pedagógico e dos conteúdos curriculares, conforme definição presente nos instrumentos de avaliação in loco de cursos.

\subsubsection{Estrutura do curso}

No que se referiu aos aspectos de qualidade da estruturação de cursos de formação inicial de professores da educação infantil e dos anos iniciais do ensino fundamental, tomouse como referência as orientações presentes nas DCN para formação de professores (BRASIL, 2002), nas DCN da licenciatura em pedagogia (BRASIL, 2006b), bem como o parecer que subsidiou as diretrizes para a formação de professores (BRASIL, 2001). Com base nessas 
referências, identificaram-se dez categorias, em torno das quais se analisou o julgamento de qualidade efetuado pelos avaliadores, a saber: (i) o tratamento do conteúdo curricular; (ii) as práticas de docência e gestão educacional; (iii) as atividades complementares; (iv) o estágio curricular; (v) o tratamento da pesquisa; (vi) as tecnologias de comunicação e informação; (vii) as modalidades de ensino; (viii) o desenvolvimento cultural dos alunos; (ix) a atuação profissional; e (x) o repertório de conhecimentos dos estudantes.

O tratamento do conteúdo curricular foi um dos itens mais observados pelos avaliadores, sendo possível identificar que para um curso atender de maneira suficiente a qualidade apurada pelo Sinaes na organização didático-pedagógica (nota três), ele deve apresentar conteúdos definidos, atualizados e coerentes com objetivos do curso e o perfil do egresso, podendo algumas ementas carecer de revisão, assim como algumas bibliografias necessitarem de ampliação e/ou atualização. A interdisciplinaridade e o desenho curricular que demandem algum tipo de adaptação ou ajuste são aceitos dentro do conceito suficiente. Observou-se, no entanto, que os avaliadores discutiram pouco sobre conteúdos e estratégias de ensino que se enquadrem nesse nível de qualidade.

Numa espécie de conector de negação, como aquele existente na lógica matemática, os relatórios indicaram, ainda, que cursos avaliados com nota dois na organização didáticopedagógica estão relacionados entre aqueles que não atendem aos parâmetros definidos para a nota três. Porém, tal lógica se estabeleceu sem que fosse possível evidenciar os pontos exatos que diferenciam um curso nota três de um curso nota dois. Por exemplo, não se teve esclarecido o que faz uma bibliografia estar desatualizada/atualizada - assumir simplesmente a data de publicação de um documento não parece ser um motivo suficiente para considerá-la ultrapassada, como é o caso do importante documento datado de 1932 e que sintetizou o Manifesto dos Pioneiros da Educação Nova, ainda hoje muito atual. Além desse exemplo, tem-se o caso das ementas e programas de disciplinas se comportam "aquém do referencial mínimo de qualidade", ou o caso da interdisciplinaridade que "não [está] adequada", sem que fosse possível identificar qualquer parâmetro para tais avaliações, conforme evidenciado a seguir a partir da avaliação de cursos nota dois:

[...] bibliografias, ementas e programas das disciplinas aquém do referencial mínimo de qualidade [...] iniciativas de interdisciplinaridade não adequadas (Relatório sobre o curso 12).

[...] bibliografia desatualizada [...] ementas e programas em desacordo com as DCN. [...] não há interdisciplinaridade (Relatório sobre o curso 13). 
Nenhum curso foi considerado como de qualidade excelente (nota cinco) ou qualidade inexistente (nota um) pelos avaliadores. Porém, entre aqueles definidos como que atendem muito bem às exigências do Sinaes na dimensão organização didático-pedagógica (nota quatro), foi possível observar que o perfil dos conteúdos curriculares é muito semelhante àquele definido para o padrão suficiente (nota três), conforme transcrições a seguir:

[...] bibliografia coerente e atualizada, sendo que precisa ser acrescida de variedade de obras (periódicos). (Relatório sobre o curso 8, que obteve nota 4 na Dimensão 1).

[...] conteúdos definidos, atualizados e coerentes com objetivos do curso e perfil do egresso [...] necessidade de revisão de algumas ementas; necessidade de ampliação de bibliografia complementar de algumas disciplinas. (Relatório sobre o curso 5, que obteve nota 4 na Dimensão 1 ).

Assim, tomando por base o item de tratamento dos conteúdos curriculares, mesmo diante de algumas indefinições conceituais, os dados apontaram uma tentativa de separação do perfil de cursos nota três e nota dois na dimensão organização didático-pedagógica. No que se referiu ao perfil dos cursos nota quatro, não foram encontrados elementos que os diferenciassem em relação aos cursos com perfil nota três.

Em relação às práticas de docência e gestão educacional, os relatórios avaliativos indicaram a necessidade de identificá-las como um aspecto particular, distinto tanto das atividades teórico-práticas quanto das atividades complementares, definidas legalmente nas DCN da pedagogia (BRASIL, 2006b). Aparentemente, tanto as atividades complementares quanto as atividades teórico-práticas serviram ao mesmo objetivo de proporcionar vivências ou experiências aos alunos em áreas específicas de seu interesse por meio da iniciação científica (IC), monitoria e extensão, diferenciando-se entre si apenas em função do trabalho de conclusão de curso (TCC) que se insere exclusivamente no quadro das atividades complementares. Já as práticas de docência e gestão educacional, conforme apareceram nos relatórios avaliativos, foram caracterizadas como vivências no âmbito da formação teórica materializando-se como experiências desenvolvidas em torno das disciplinas curriculares.

Nesse sentido, entendendo as práticas de docência e gestão educacional ${ }^{58}$ como uma complementaridade das atividades teóricas, os dados apontam para uma preocupação dos avaliadores nesse aspecto, sendo possível identificar parâmetros mais claros para a diferenciação das notas em relação a ele, a saber: nota dois, cursos que não possuem ou não utilizam no cotidiano acadêmico laboratórios pedagógicos e brinquedoteca; nota três, cursos que apresentam espaços destinados a atividades práticas e os utilizam; nota quatro, cursos que

\footnotetext{
${ }^{58}$ Com base no inciso II do artigo $8 .^{\circ}$ das DCN da licenciatura em pedagogia (BRASIL, 2006b).
} 
contam com espaço de prática e os utilizam a partir de projetos sistematizados, institucionalizados e articulados com o projeto pedagógico e que oportunizam o exercício da prática entre os alunos de forma continuada e articulada aos conteúdos teóricos.

No que se referiu às atividades complementares, observou-se que entre os cursos que receberam nota dois na dimensão de organização didático-pedagógica, os avaliadores apontaram que tais atividades ocorriam no âmbito das disciplinas, sem a individualização prescrita pelas DCN do curso; ou ainda quando a avaliação do TCC não contava com uma análise detalhada ou avaliação séria dos resultados apresentados pelos alunos. Já os cursos com nota três, gozavam de sistematização das atividades complementares, com mecanismos de acompanhamento, tendo sido observado um caso que, mesmo o TCC precisando de algum ajuste, o curso foi enquadrado nesse nível de qualidade. Em relação aos cursos nota quatro, o relato dos avaliadores aproximaram os parâmetros àqueles presentes nos cursos nota três. No entanto, é preciso alertar que, considerando os dados disponíveis, não foi possível identificar análises específicas sobre cada uma das atividades complementares que compõem o projeto pedagógico dos cursos, em geral tomadas como um bloco. De forma pouco consistente, foi possível evidenciar apenas que o TCC e as atividades de extensão foram citados de forma mais frequente nos relatórios, em comparação com a monitoria ou a iniciação científica.

O estágio curricular foi outro item muito presente nas análises dos avaliadores, porém não foram observados parâmetros capazes de diferenciar a qualidade dos cursos nesse aspecto. De forma geral, os dados mostraram uma preocupação com a sistematização do estágio e sua adequação à carga horária definida legalmente, sem que tivessem sido feitas referências ao formato, áreas temáticas ou outros fatores que pudessem indicar uma parametrização da qualidade dos estágios em relação à nota aferida na dimensão didáticopedagógica.

Em relação ao tratamento da pesquisa, os dados analisados apontaram que quando o curso não esclareceu o tratamento da pesquisa, os avaliadores atribuíram nota dois à dimensão de organização didático-pedagógica. Já quando o avaliador analisou o tratamento dado pelo curso à pesquisa e o associou ao TCC ou à iniciação científica, o curso recebeu nota três na dimensão didático-pedagógica. Naqueles casos em que o tratamento da pesquisa foi associado à edição de revistas científicas ou à participação de professores e alunos em projetos de pesquisas/eventos científicos, a nota na dimensão foi quatro. Há que se ressaltar, no entanto, que apenas um pouco mais da metade dos relatórios analisados fizeram referência direta a esse aspecto de qualidade, o que, de certa forma, fragilizou esse esboço de parametrização da 
qualidade dos cursos nesse aspecto, uma vez que nem sempre a atenção do avaliador foi atraída por ele.

No que se referiu à Tecnologia de Comunicação e Informação (TIC), embora o item esteja explicitamente citado nas DCN de formação de professores e nas da licenciatura em pedagogia, menos da metade dos relatórios de avaliação in loco trouxeram a visão dos avaliadores sobre esse aspecto da realidade do curso. Entre os relatórios que fizeram referência às TIC, metade se reportou à falta de acesso dos alunos a computadores, sendo coerentes em atribuir, na dimensão organização didático-pedagógica, nota dois aos cursos que apresentaram essa realidade. Porém, não foi possível identificar um parâmetro para a diferenciação da qualidade dos cursos em relação às TIC para as notas três e quatro. Além disso, as descrições tendem a se restringir aos equipamentos como parte da infraestrutura, sem ampliar a análise para a necessidade de interação dos alunos com as novas mídias, tampouco a introdução de conteúdos curriculares a partir delas, conforme sugeriu o diagnóstico que subsidiou as DCN de formação de professores (BRASIL, 2001).

Sobre o item pertinente à modalidade em que são atendidos os alunos da educação básica (educação de jovens e adultos, educação indígena, educação especial...) apenas um relatório de avaliação analisado trouxe referência a eles. Com isso, aparentemente, os dados indicaram não existir um olhar do Sinaes sobre esse item. Tal afirmativa parece ser válida também em relação aos aspectos sobre desenvolvimento cultural e ao tratamento da atuação profissional do pedagogo em formação. No primeiro caso, as oportunidades de desenvolvimento facilitadas pelo acesso a livros, vídeos, produções culturais de naturezas diversas, entre outras, foram pouco observadas pelos avaliadores (dois casos, apenas). No segundo, experiências trazidas pelo próprio aluno, em suas possíveis vivências como profissionais, na regência de classes, em projetos de escolas da educação básica ou no sistema educacional, não foram objetos de análise para aferição da qualidade do curso, considerando a amostra de relatórios analisada nesta pesquisa.

Sobre o repertório de conhecimentos trazidos pelos estudantes, se constatou, por fim, que tal aspecto foi destacado quando os cursos promoveram ações para o nivelamento dos alunos em áreas como português e matemática, ou para a assistência psicopedagógica quando os discentes apresentavam dificuldades em acompanhar o curso. Nos casos em que essa forma de atenção aos discentes foi identificada, a nota atribuída à dimensão didático-pedagógica foi quatro. Porém, não foi possível qualquer parametrização envolvendo esse item, uma vez que exatamente metade dos cursos que obteve nota quatro nessa mesma dimensão não 
desenvolvia atividades indicativas de preocupação em torno dos conhecimentos trazidos pelos estudantes, as quais tivessem merecido destaque por parte dos avaliadores.

Dessa forma, no conjunto de aspectos analisados nessa seção, apenas em relação às práticas de docência e gestão educacional foi possível mapear parâmetros a partir dos quais seria possível estruturar os critérios de qualidade utilizados pelo Sinaes de forma sistemática. Em relação aos demais itens (tratamento do conteúdo curricular, atividades complementares, estágio curricular, tratamento da pesquisa, tecnologia de comunicação e informação; modalidade de ensino, desenvolvimento cultural, atuação profissional e repertório de conhecimentos dos estudantes), embora tivesse sido possível o delineamento de alguns parâmetros para a aferição da qualidade deles, os dados analisados não apontaram para o estabelecimento de critérios consistentes para a definição da qualidade apurada.

\subsubsection{Outros aspectos: gestão, legalidade, repertório de conhecimentos dos estudantes, parcerias e autoavaliação}

$\mathrm{Na}$ análise dos relatórios de visitas realizadas pelo Sinaes para avaliar a qualidade dos cursos foi possível, ainda, destacar aspectos de qualidade que não foram previamente mapeados no marco teórico - caso da gestão do curso -, bem como outros aspectos evidenciados pela comparação com a experiência internacional desenvolvida na Austrália, a saber: (i) legalidade; (ii) repertório de conhecimento dos estudantes; (iii) parcerias para estágio e (iv) autoavaliação.

No que se referiu à gestão do curso, aspectos relativos à articulação entre as instâncias estratégicas e operacionais da instituição formadora foram observados pelos avaliadores em prol da coerência entre o projeto pedagógico e o plano de desenvolvimento institucional. Além disso, foi possível também observar uma atribuição positiva aos mecanismos de participação dos segmentos discente e docente nas decisões administrativas e técnicas. No entanto, apesar de os citados aspectos estarem contemplados nos relatos dos avaliadores, eles apenas definiram o perfil de curso com qualidade suficiente (nota três), ou a sua negação (nota dois - insuficiente), sem que os demais níveis da escala pudessem ser parametrizados em relação a ele.

Já a comparação do comportamento do Sinaes na avaliação de cursos de formação docente com a experiência australiana, observou-se que, diferentemente do que ocorreu no país estrangeiro, nem todos os requisitos legais foram exigidos, nem se configuraram como uma condição indiscutível para que os cursos sejam qualificados no sistema. Assim, quando a 
avaliação do Sinaes identificou que algum curso não atendeu a alguns dos itens especificados legalmente, isso não foi considerado como parâmetro para que a Dimensão 1 deixasse de atender de forma suficiente a qualidade estabelecida pelo sistema. Exemplo disso foi o relatório sobre o curso 14, no qual os avaliadores constataram que "2.740 (duas mil setecentos e quarentas horas) [são destinadas] ao desenvolvimento de disciplinas teóricas e práticas", quando o mínimo legal exigido é de 2.800 horas e, ainda assim, o curso obteve nota três na dimensão organização didático-pedagógica. Mais ilustrativo ainda foi o relato sobre o curso 6, no qual os avaliadores atribuíram nota quatro à dimensão 1, após afirmar que ele "apresenta certa [grifo nosso] coerência dos conteúdos curriculares com as Diretrizes Curriculares Nacionais". Identificou-se, ainda, que as DCN de formação de professores foram declaradas como parâmetro de legalidade no caso do curso 16, sem que as diferenças de concepção existentes entre essa norma e as DCN da licenciatura em pedagogia tivessem sido declaradas, nem especificadas pelos avaliadores do Sinaes.

Outro importante aspecto existente na avaliação da qualidade dos cursos de formação de professores australianos e que contrastou com o que se levantou no caso do Sinaes foi a preocupação do primeiro com o nível de conhecimentos trazidos pelos alunos: eles exigem como pré-requisito para ingresso no curso que os discentes comprovem desempenho compatível ao alcançados pelos $30 \%$ mais bem classificados em testes nacionais de proficiência em línguas e conhecimentos matemáticos. Quando o curso não utiliza essa barreira na seleção, os australianos exigem a promoção de iniciativas para suprir as carências dos alunos.

Na realidade do Sinaes, o despreparo e/ou a desmotivação dos alunos pareceram ser mais diretamente associados a uma desculpa pela baixa nota do curso na apuração do CPC do que numa obrigação das IES para adotar procedimentos que auxiliassem o aluno em suas dificuldades. Por exemplo, no relatório sobre o curso 6, os avaliadores aceitaram como desculpa para o baixo CPC "defasagens advindas do processo de formação anterior e que precisam ser melhoradas", associadas ao fato de que os "alunos não participam de cursos e oficinas" oferecidos para superar essas dificuldades. Já os avaliadores do curso 3 afirmaram que o calor afastou a presença dos alunos no Enade, justificando a nota aferida no desempenho dos alunos em função da sua baixa motivação para fazer a prova em instalações não climatizadas, escolhidas como local de realização do Exame. Tais desculpas, na perspectiva desta pesquisa, em vez de justificar, pareceram reforçar ainda mais a pouca qualidade do curso. Os dados sugeriram que, além de as IES em foco não selecionarem adequadamente os discentes ou, pelo menos, interferirem proativamente na superaração das 
dificuldades em sua formação básica, ainda argumentaram em função da desmotivação ou carência de conhecimentos prévios dos alunos. Aparentemente, utilizaram as carências dos alunos para justificar uma nota insuficiente no Enade e, por consequência, na apuração do $\mathrm{CPC}$, sem reconhecer aquilo que a instituição deveria desenvolver em prol do desempenho dos professores em formação.

Em síntese, os relatórios apontaram para a possibilidade de as IES utilizarem a falta de motivação e/ou preparo dos alunos em conhecimentos basilares para a sua formação como desculpa para o mau desempenho nas aferições de qualidade feitas pelo Sinaes. Adicionalmente, entre os casos analisados, não houve reconhecimento de quaisquer responsabilidades das IES sobre a seleção dos alunos para ingresso no curso, sobre a falta de motivação deles para a realização do Enade nem sobre a deficiência do curso em desenvolver as competências medidas pelo exame. Além disso, não se observou posicionamento dos avaliadores diante de tal situação, quando elas apareceram.

No que se referiu aos processos autoavaliativos, os relatórios do Sinaes trouxeram esse aspecto como desejável, enquanto no processo australiano ele pode ser visualizado como necessário. A questão da autoavaliação esteve presente em todos os relatórios analisados. Porém, independentemente da nota atribuída ao curso, não houve recomendação expressa pela instalação de Comissão Própria de Avaliação (CPA). Inclusive houve um caso em que, apesar de a CPA ter sido desfeita, a presença de iniciativas autoavaliativas do Núcleo de Referência Docente foi considerada adequada. Além disso, também não foram observados parâmetros em torno dessa institucionalização e resultados dessa ação que pudessem ser revertidos em critérios de qualidade para a avaliação dos cursos.

Por fim, no que se referiu às parcerias para a realização de estágio dos alunos, apenas duas análises contemplaram esse item, sem que houvesse um impacto mais significativo na nota observada dos cursos. Dessa forma, pôde-se sugerir que, diferentemente do que ocorreu na Austrália, o fato de existirem espaços institucionalizados para a realização de estágios não pareceu interferir na medida de qualidade aferida pelo Sinaes para cursos de pedagogia.

\subsubsection{Conceito Preliminar de Cursos e sua relação com a avaliação in loco}

Retomando aqui o contexto apresentado na seção 2.2 deste trabalho, procurou-se detalhar o sentido de complementaridade - trazido pelo ordenamento legal (BRASIL, 2007d) - entre o CPC e as avaliações in loco no âmbito do Sinaes. Nesse contexto, analisaram-se detalhadamente as relações existentes entre os indicadores e os parâmetros presentes nesses 
dois instrumentos avaliativos, as quais, legalmente, vêm permitindo a adoção do CPC como um indicador que seleciona os cursos para receber as visitas in loco.

Para tanto, primeiramente, partiu-se dos esclarecimentos exarados pela Nota Técnica n. ${ }^{\circ}$ 029, de 15 de outubro de 2012 (INEP, 2012b), para descrever os critérios de qualidade do CPC por meio dos seus componentes, conforme segue:

a) Nota de Professores Doutores (peso 0,15) e Nota de Professores Mestres (peso 0,075) esse componente assumiu como critério de qualidade o simples estoque de conhecimento do docente, certificado pelo diploma de mestre ou doutor. A importância e a necessidade do uso desse estoque de conhecimento na realidade do curso (comumente aferida por meio da produção bibliográfica, técnica e artística qualificada) foram desconsideradas no cálculo desse indicador, a despeito da existência de grandes bancos de dados públicos sobre essa produção. Além disso, aspectos como pertinência da área de conhecimento da titulação docente à área do curso, bem como experiência profissional do professor, previstos nos relatórios de visitas in loco, foram negligenciados na geração do CPC. Na mesma linha, aspectos relativos à experiência e formação da coordenação do curso, presentes na avaliação in loco, não foram considerados na vigente fórmula de cálculo do CPC. Registra-se, ainda, que a recente mudança no cálculo do CPC fez com que o peso do título de mestre aumentasse de 5\% para 7,5\%. Em contrapartida, o peso do docente titulado com doutorado, caiu de $20 \%$ para $15 \%$. Essa mudança favoreceu diretamente as IES privadas, conforme sugerido por Bittencourt et al. (2010), ${ }^{59}$ sem que as devidas explicações fossem apontadas na Nota Técnica n. 0 029/2012 (INEP, 2012b).

b) Nota de Professores com Regime de Dedicação Integral ou Parcial (peso 0,075) - o critério de qualidade inerente a esse componente não assumiu a dedicação integral como um degrau mais avançado, em relação à dedicação parcial para a qualidade do curso. De certa forma, esse componente, aparentemente, indicou que o mais importante para fazer um bom curso é o tipo do vínculo que se estabeleceu entre o docente e a instituição, independentemente do tempo que ele dedicou para realizar o trabalho de formação dos alunos na IES. Tal tendência também esteve presente no instrumento de visita in loco, o qual igualmente não fez distinção entre a quantidade de horas dedicadas pelos docentes ao trabalho de formação na IES, tampouco às atividades de pesquisa e extensão. ${ }^{60}$ Assim,

59 As IES privadas possuem uma quantidade proporcionalmente menor de doutores que as IES públicas, beneficiando-se com a redistribuição do peso entre esses itens, realizada pelo Inep.

${ }^{60}$ As atividades de pesquisa e extensão não fazem parte das atribuições de professores em regime parcial, conforme diferença entre os dois regimes de dedicação docente estabelecida pelo CNE no Parecer CNE/CES n. ${ }^{\circ} 121$, de 10 de maio de 2007 (BRASIL, 2007e). 
tanto na visita avaliativa quanto no cálculo do CPC, o tempo integral não foi considerado como potencialmente ampliador da capacidade de o docente atender de forma mais individualizada e qualitativa um maior número de alunos da instituição.

c) Nota de Infraestrutura (peso 0,075) - o CPC afere a qualidade de infraestrutura do curso por meio da percepção dos alunos sobre a quantidade de equipamentos disponíveis para a realização de aulas práticas, apurada durante o Enade. Esse procedimento, a despeito do seu baixo custo de levantamento pelo Inep, pareceu representar uma medida de qualidade pouco útil, restrita ao ponto de vista dos alunos, o qual pode ser tão variado ${ }^{61}$ que dificilmente permitiria uma efetiva agregação do significado das respostas processadas. Além disso, do ponto de vista de orientação do sistema, não foi possível estabelecer o que o Sinaes considerou efetivamente, no âmbito do CPC, como uma estrutura suficiente em termos de biblioteca, salas para aulas teóricas, higiene/limpeza ou acessibilidade. Alguns desses aspectos de infraestrutura, inclusive, foram previstos no instrumento de avaliação de cursos in loco, demonstrando a sua relativa importância para o sistema avaliativo. No entanto, a forma de apuração do CPC não os levou em consideração, marcando mais uma das diferenças entre os dois instrumentos utilizados pelo Sinaes para a avaliação de cursos.

d) Nota da Organização Didático-Pedagógica (peso 0,075) - componente que vem sendo aferido durante o Enade, por meio da percepção dos estudantes em relação à estrutura de um plano de ensino. Tal simplificação em sua medida, quando contrastada com as possibilidades de sua construção discutidas na subseção 3.2.1 deste trabalho, aliada ao peso de sua importância presente no instrumento de avaliação in loco, pareceu colocar em suspeição a qualidade apurada pelo CPC. Considerou-se preocupante o fato de o sistema avaliativo restringir a dimensão de organização didático-pedagógica de um curso à estrutura de um plano de ensino. Não bastasse essa forma inusitada de representar a referida dimensão na fórmula de cálculo do CPC, tal representação foi operacionalizada por meio da simples percepção dos estudantes para mensurar a qualidade do componente em análise, quando, mesmo entre especialistas, há divergência entre concepções ideais para a formação de professores.

e) Nota dos Concluintes no Enade (peso 0,20) - um dos principais componentes para a geração do CPC, as notas de desempenho dos discentes tenderam a agregar pouco na

\footnotetext{
${ }^{61} \mathrm{O}$ ponto de vista do aluno pode oscilar, entre outras possibilidades, desde a sua vontade de fazer sozinho uma atividade que o projeto pedagógico do curso estrutura de forma coletiva, passando pelo seu humor em relação à instituição e indo até à orientação deliberada sobre as respostas a serem dadas em um quesito que responde por $7,5 \%$ do CPC.
} 
mensuração efetiva da qualidade do curso, notadamente no que se referiu à prova de conhecimentos gerais (que corresponde a $25 \%$ da nota gerada), tendo em vista as competências trazidas pelo próprio estudante e suas motivações para fazer a prova. Conforme discutido por Verhine e Dantas (2008), o principal argumento da crítica a essa variável relacionou-se ao fato de que as condições socioeconômicas individuais são um diferencial que influenciam diretamente na nota Enade, independentemente daquilo que o curso agregou. Além disso, quando se comparou esse componente do CPC com o instrumento de avaliação in loco do curso, observou-se que o desempenho dos alunos no Enade não foi utilizado nas visitas avaliativas, mesmo diante da possibilidade de se detalhar os conteúdos trabalhados no curso e sua apreensão pelos alunos.

f) Nota do Indicador de Diferença entre os Desempenhos Observado e Esperado (NIDD) (peso 0,35) - indicador recentemente modificado pelo Inep, com base em uma sofisticada metodologia de ordem estatística, tendo em vista a incorporação da nota do Exame Nacional do Ensino Médio (Enem) em lugar da nota do ingressante do Enade. Há necessidade de uma série histórica para se analisar o impacto das mudanças. Porém, pelo menos conceitualmente, ao considerar a nota do ingressante advinda do Enem, o Sinaes pareceu ter resolvido apenas um problema de custo, economizando os recursos financeiros da aplicação da prova ao grupo de ingressantes. Na análise da nota técnica, não foi possível encontrar elementos que permitissem superar a crítica feita por Verhine e Dantas (2008), cuja base foi o fato de esse indicador comparar o desempenho de grupos diferentes de alunos que possuíam perfis distintos, seja pelas características pessoais, seja pelas transformações socioeconômicas, agregando pouco sobre a qualidade do curso em função da validade de sua medida. Conforme pôde ser depreendido, o cálculo continuou comparando grupos diferentes de alunos. A nota do Enem, segundo informado pela Nota Técnica n. ${ }^{\circ}$ 029/2012 (INEP, 2012b), referiu-se ao Cadastro de Pessoa Física (CPF) do ingressante no curso, e não ao CPF do aluno concluinte, quando aparentemente seria possível comparar os conhecimentos gerais dos concluintes com aqueles trazidos por eles próprios, aproximando-se o item de conhecimentos gerais do Enade a questões do próprio Enem.

Assim, comparando os componentes do CPC com os parâmetros e indicadores utilizados na avaliação in loco de cursos, percebeu-se que, além de fragilidades que ambos têm com instrumentos de medida e julgamento da qualidade da licenciatura em pedagogia, existe ainda certo afastamento na definição dos seus indicadores, notadamente nas dimensões organização didático-pedagógica e infraestrutura, sem que tenha sido possível, a partir dos 
dados analisados, estabelecer qualquer relação dialética entre eles. Talvez por isso se tenha observado uma sinalização diferente sobre a qualidade dos cursos de pedagogia, quando se comparam os resultados aferidos pelo CPC com aqueles apresentados pela avaliação in loco, sem que se tenha resolvido qual das duas medidas representa a qualidade considerada pelo Sinaes.

Para exemplificar essa assertiva, sistematizaram-se os movimentos de subida e descida das notas dos cursos entre os ciclos avaliativos, na Tabela 7. Para tanto, considerou-se a amostra de cursos, cujos relatórios de avaliações in loco foram analisadas nesta pesquisa. Em relação a esses cursos, considerou-se a nota referente a 2008, estabelecida pela visita avaliativa, e a nota gerada para eles com base no CPC 2011. Como esperado em função da análise realizada, houve diferença entre a nota de qualidade apurada para um mesmo curso, a despeito do fato de terem sido atribuídas quase ao mesmo momento, em função do curto lapso temporal entre realização das avaliações in loco referentes ao CPC 2008 e a geração do CPC 2011.

Tabela 7 - Distribuição dos cursos da amostra de relatórios de avaliação in loco, em função da nota aferida em 2008 e da nota no CPC 2011.

\begin{tabular}{c|c|c|c|c}
\hline \multirow{2}{*}{ CPC 2011 } & \multicolumn{4}{|c}{ Nota da avaliação in loco, válida como conceito de curso referente a 2008.} \\
\cline { 2 - 5 } & Cursos com Nota 2 & Cursos com Nota 3 & Cursos com Nota 4 & Total de cursos \\
\hline Total de cursos & 1 & 7 & 4 & 12 \\
Cursos com Nota 1 & - & 1 & - & 1 \\
Cursos com Nota 2 & - & - & 1 & 1 \\
Cursos com Nota 3 & 1 & 6 & 1 & 8 \\
Sem conceito (SC) & - & - & 2 & 2 \\
\hline
\end{tabular}

Fonte: Inep [2013]; amostra de relatórios de avaliação de cursos in loco, analisados nesta pesquisa.

Nota: SC = Sem conceito. Esse registro é gerado quando não há insumo para o cálculo do indicador (tais como nota de ingressantes ou concluintes).

Os números revelaram que, a despeito do pouco tempo decorrido entre a apuração de uma medida e a outra (as visitas foram realizadas entre 2010 e 2011), os cursos que receberam nota quatro na avaliação in loco não mantiveram a nota pelas regras de apuração do CPC 2011. Também chamou a atenção o fato de um curso classificado como de qualidade insuficiente (nota dois) na avaliação in loco ter logrado nota três no CPC quase que ao mesmo tempo. 
Aqui cabe um "parêntese" para entender melhor essa última situação. Compararam-se as notas obtidas por esse curso nos componentes utilizados para gerar a nota no CPC em 2008 e 2011, levando-se em conta os fatores que explicariam como ele melhorou entre um ciclo e outro. O que se identificou foi a melhoria nas notas de professores doutores, professores com dedicação integral e parcial, além das notas geradas em infraestrutura e organização didáticopedagógica (essas duas últimas em função da significativa guinada estabelecida pelos alunos, que passaram a avaliar muito bem a disponibilidade de equipamentos e os planos de ensino do curso). Porém, no que se referiu ao desempenho dos estudantes e a sua repercussão no NIDD houve, ao contrário, um pequeno decréscimo nas notas apuradas entre 2008 e 2011.

Essa situação específica não permitiu afirmar que houve má fé da IES ou intenção deliberada de melhorar o seu CPC por meio de informações cadastradas sobre seu corpo docente no Censo da Educação Superior, tampouco que foram dadas orientações expressas aos alunos sobre a importância de melhorar suas percepções em termos da infraestrutura e da organização didático-pedagógica do curso. Por outro lado, sinalizou a desconexão entre os instrumentos utilizados pelo Sinaes para gerar as notas, seja em função da pouca afinidade entre os indicadores presentes nos instrumentos avaliativos - que mensuram um mesmo aspecto de formas diferentes e sem complementaridade -, seja pela precariedade dos indicadores que compõem o CPC - que permitiu considerar como melhoria da qualidade de um curso os rearranjos de fatores periféricos, sem que a qualidade do produto esperado na formação dos futuros pedagogos tivesse sido alterada positivamente.

Fechando o "parêntese" aberto pela situação analisada, os dados sistematizados pela Tabela 1 permitiram observar, ainda, que seis dos sete cursos da amostra qualificados com nota três na avaliação in loco mantiveram a mesma nota no CPC. No entanto, tal correlação quantitativa não foi acompanhada de um padrão qualitativo que contrabalançasse as desconexões anteriormente apontadas. Essa aparente convergência entre as notas apuradas não foi capaz de superar as dúvidas sobre a interconexão entre os dois instrumentos de medida em função da precariedade, já apontada, dos indicadores utilizados pelos instrumentos avaliativos, aliada ao fato de que eles terminam por medir aspectos diferentes: o Enade, que compõe de forma central a avaliação de cursos viabilizada pelo CPC, tem sido completamente ignorado entre os indicadores utilizados pela avaliação in loco.

Nesse sentido, a partir dos dados evidenciados nesse estudo, conceitos de cursos atribuídos via CPC não pareceram comparáveis aos conceitos de cursos atribuídos via avaliação in loco. Essas medidas fazem uso de indicadores diferentes e, portanto, tendem a apresentar a realidade também de uma forma diferenciada. Ao contrário do que se poderia 
esperar, a análise dos dados sinalizou que os critérios utilizados pela avaliação in loco não aprofundaram aspectos considerados pelo CPC, notadamente em torno dos resultados gerados pelo Enade, tampouco estabeleceram articulações com a proposta pedagógica do curso e seus desdobramentos na estrutura curricular, estágios, atividades complementares, corpo docente e infraestrutura, entre outros. A comparação dos dois processos avaliativos indicou a existência de repetição das mesmas dimensões de análise tanto no CPC quanto na avaliação in loco, tomadas a partir de indicadores e parâmetros em grande parte diferenciados. Como resultados, observaram-se sinalizações também diferenciadas sobre o que é qualidade, complexificando o sistema avaliativo, sem necessariamente estabelecer um significado de qualidade.

\subsubsection{O Enade como indicador de qualidade}

A centralidade do Enade na composição do CPC, demonstrada por meio do conjunto dos pesos referentes aos componentes diretamente advindos do Exame (NIDD, nota do concluinte, nota da infraestrutura e nota da organização didático-pedagógica) justificou a necessidade de um aprofundamento desse componente do Sinaes, no contexto da avaliação de cursos. Dessa forma, nessa seção, o Enade foi observado de forma mais próxima, do ponto de vista do seu conteúdo e de sua repercussão no Sistema Federal de Ensino Superior.

Na opinião de Barreyro (2008) as questões do Enade não permitem a comparabilidade dos resultados entre os cursos avaliados, seja dos cursos em um mesmo ano, seja entre o mesmo curso a cada três anos, porque não utilizam a Teoria de Resposta ao Item (TRI). ${ }^{62}$ Já Verhine e Dantas (2008) apontaram o pequeno número de questões utilizadas para medir o conhecimento e as competências definidas, tanto para o componente geral quanto para o componente específico, como limitações do Exame. Conforme afirmaram os autores, os Resumos Técnicos do Enade, produzidos no ciclo 2004/2006, não possibilitaram identificar a lógica inerente à mensuração do conhecimento que embasou o componente de formação geral. No que se referiu ao componente específico, embora mais difícil de avaliar em função das diferentes áreas, eles consideraram que 30 questões seriam insuficientes para analisar a aprendizagem do discente em todo um campo de conhecimento.

\footnotetext{
62 Araújo, Andrade e Bortolotti (2009) esclareceram que a TRI visa completar lacunas observadas nos testes clássicos, possibilitando fazer comparações entre resultados apresentados por indivíduos, independentemente de fatores econômico-sociais que os diferenciam, quando submetidos a um mesmo teste, bem como comparar indivíduos com características semelhantes, quando submetidos a testes diferentes. Segundo os autores, isso é possível porque a TRI tem como elemento central o item, sem desconsiderar os escores totais do teste aplicado. Com isso, essa forma de mensuração facilita a interpretação da escala gerada, bem como a identificação de informações produzidas, inclusive em relação a itens que não são respondidos.
} 
Os resultados encontrados por estudo realizado por Souza (2013) confirmaram, no caso da pedagogia, a hipótese de Verhine e Dantas (2008) de que as questões do Enade no seu componente específico são insuficientes para avaliar o desempenho dos discentes em relação a todo o conhecimento de uma área do saber. Como exemplo, o referido estudo destacou que alguns conteúdos da pedagogia, como aqueles ligados à Sociologia da Educação, apareceram apenas uma vez nas três edições do Exame, enquanto outros, notadamente aqueles vinculados à prática docente, tais como i) Conteúdos e Metodologias Específicas de História; ii) Ludicidade; e iii) Corporeidade/Motricidade Humana, jamais foram contemplados com questões no Exame.

Em síntese, a análise de Souza (2013) apontou que, no instrumento que mede o desempenho dos estudantes de pedagogia, a frequência de questões relativas aos conteúdos definidos pelo próprio Enade como ligados à formação stricto sensu do pedagogo como professor e como especialista em educação, além de baixa (em torno de $25 \%$ e $10 \%$ respectivamente), está diminuindo no componente específico da docência ao longo das edições de exame (passou de um patamar de quase 32\% em 2005, para 28\% em 2008 até atingir 20\% em 2011). Isso pareceu indicar que o Enade da pedagogia está focalizando conhecimentos por ele classificado como "gerais", que dão a base para a formação do pedagogo, mas que não definem a sua profissionalidade como docente, nem na forma indicada por Gatti (2010) - que assume os conhecimentos ligados aos conteúdos do currículo da educação básica (infantil e fundamental) e às didáticas específicas, metodologias e práticas de ensino como imprescindíveis à sua formação -, nem naquela trazida pelas DCN do curso, que amplia a perspectiva de docência, assumindo também os conteúdos necessários à formação do especialista em educação como complementares à formação do docente.

Considerando o conteúdo específico do Enade, observou-se também a sua relação com os objetos de conhecimento propostos pela prova docente. Nesse aspecto, constatou-se que enquanto o Exame se concentrou em aspectos da formação geral do pedagogo, os eixos dos objetos de conhecimento da prova docente se estruturaram a partir daquilo que as diretrizes de organização do Enade ${ }^{63}$ identificaram como Área Específica da Docência, acrescidas de três tópicos integrantes da área de formação geral. ${ }^{64}$ Nesse sentido, a relação entre os conhecimentos medidos pelo Enade e aqueles propostos pela prova docente na área de

63 Portaria no 225, de 26 de julho de 2011, (BRASIL, 2011e).

64 Políticas Educacionais; Organização e Gestão do Trabalho Pedagógico (que no Enade é chamado de Organização e gestão da escola, Planejamento educacional e Projeto Político-Pedagógico); e Desenvolvimento, Ensino e Aprendizagem, que no Enade envolve os tópicos Psicologia da Educação (aprendizagem e desenvolvimento) e Teorias Pedagógicas. 
pedagogia implicou concepções diferenciadas de docência que podem comprometer uma futura convergência entre os dois processos avaliativos.

Em linhas gerais, os dados disponíveis apontaram para a dificuldade do Enade em contemplar as especificidades da formação do docente para a educação infantil e os anos iniciais do ensino fundamental. Talvez por isso, em função de tais limitações, sua repercussão em termos da contribuição efetiva para a melhoria da qualidade das IES tenha sido baixa, conforme relatos de Rodrigues e Peixoto (2009) e de Oliveira et al. (2013). Por outro lado, mesmo reconhecendo a necessidade de ajustes dos itens do Enade, seja no sentido indicado por Barreyro (2008), seja na aproximação de seu conteúdo às áreas definidas pelo próprio Exame como da docência, compartilhou-se da visão de Verhine e Dantas (2008) de que o Enade é um importante instrumento para a discussão, regulação e ajustes na qualidade da educação superior em geral e dos cursos de pedagogia em particular.

\subsection{O QUE REVELAM AS AVALIAÇÕES DE CURSOS DO SINAES SOBRE A QUALIDADE DA FORMAÇÃO DE PEDAGOGOS NO BRASIL?}

No seu conjunto, os dados analisados pareceram conduzir ao entendimento de que a qualidade da formação do pedagogo no Brasil revelada pelo Sinaes tem padrões pseudodefinidos. Dois foram os achados principais: i) - a avaliação in loco não estabeleceu parâmetros capazes de identificar os perfis de qualidade relativos aos cinco níveis da escala do Sinaes, seja em função do uso de indicadores e parâmetros pouco claros para a valoração (atribuição de notas) da dimensão organização didático-pedagógica, seja pelo uso de critérios de qualidade dissociados de oportunidades de aprendizagens para os alunos, nas dimensões infraestrutura e corpo docente e tutorial; e ii) - não foi possível estabelecer relações entre os critérios utilizados pelo CPC e pelas avaliações in loco para aferir a qualidade das licenciaturas em pedagogia, em função das diferenças no tratamento dos componentes de cada um dos processos, tanto no que se refere aos resultados do Enade, central no primeiro e totalmente desconsiderado no segundo, como também no que se referiu à organização didático-pedagógica e à infraestrutura, reduzidas cada uma, no CPC, a uma questão retirada do Questionário do Estudante que integra o Enade.

No caso das avaliações in loco, o Sinaes até conseguiu diferenciar os cursos de pedagogia avaliados com nota dois, qualidade insuficiente, daqueles avaliados com nota três, qualidade suficiente. Porém, houve pouca clareza sobre o significado específico dos perfis gerados por essas notas: não foi possível definir expressões como "interdisciplinaridade 
adequada", "conteúdo pertinente" ou "referencial de qualidade para ementas e programas de disciplinas". Com isso, os dados não permitiram estabelecer qualquer entendimento sobre o que os avaliadores se referiram quando julgaram o tratamento do conteúdo curricular, as atividades complementares ou o estágio curricular, entre outros aspectos, como suficiente ou insuficiente.

Já no caso do CPC, a mistura de componentes de natureza diversas gerou como resultado um número tão abstrato que pouco contribuiu para sinalizar, por si só, o que o curso trouxe de bom ou ruim. Apesar de os pesos entre os componentes sobrelevar a importância do desempenho discente no Enade, uma mesma nota gerada pelo CPC pode indicar tanto que o curso tem espaço para melhorar as características do seu corpo docente quanto a sua organização didático-pedagógica ou ainda em qualquer outro componente ou combinação de componentes desse indicador de qualidade.

Adicionalmente, observaram-se indefinições no que se referiu à posição do Sinaes em relação à legislação nacional que regula a oferta de cursos de graduação. $\mathrm{O}$ atendimento aos requisitos legais não figurou como um dos componentes do CPC para o cálculo das notas dos cursos. De forma semelhante, os relatórios das avaliações in loco, apesar de trazerem listados os requisitos legais, não deram qualquer tipo de tratamento a possíveis irregularidades identificadas. Tal situação foi assim explicada pelo instrumento de avaliação in loco:

Estes itens [requisitos legais e normativos] são essencialmente regulatórios, por isso não fazem parte do cálculo do conceito da avaliação. Os avaliadores apenas farão o registro do cumprimento ou não do dispositivo legal e normativo por parte da instituição para que o Ministério da Educação, de posse dessa informação, possa tomar as decisões cabíveis (INEP, 2012a, p. 26).

Com isso, ficou subentendido que o Sinaes vem admitindo que um curso de graduação em geral, e de pedagogia em particular, mesmo não obedecendo à legislação, ainda assim poderia ser considerado entre aqueles com perfil de qualidade suficiente, muito boa ou excelente. Aparentemente, é como se as notas resultantes do processo avaliativo não fossem, elas próprias, o principal insumo para a regulação da educação superior no Brasil. Além disso, pontua-se que não foi encontrado o detalhamento de procedimentos utilizados pelo MEC para detectar um curso que não está obedecendo à lei, quando este recebe uma avaliação positiva do Sinaes (seja via CPC, seja via avaliações in loco).

Entre os casos analisados neste estudo, encontrou-se no relatório da avaliação in loco sobre o curso 15 um exemplo concreto dessa realidade. Esse curso recebeu nota três como resultado do processo avaliativo a que foi submetido, embora os avaliadores tenham 
encontrado uma desobediência legal em relação às condições de acesso para pessoas com deficiências e/ou mobilidade reduzida. Diante desse fato, seria esperado algum tipo de procedimento de ajuste de conduta/notificação do curso sobre a necessidade a atendimento à legislação. Porém, não houve registro de qualquer tipo de diligência a esse respeito no sistema responsável pelo gerenciamento de informações de regulação e supervisão da educação superior no País (E-MEC, 2014).

Ainda no campo legal, decorrente das expectativas geradas pelo parecer que subsidiou as DCN de formação de professores (BRASIL, 2001), a qualidade da formação do pedagogo no Brasil revelada pelo Sinaes não aprofundou aspectos em torno do desenvolvimento de aptidões dos egressos para atuar nas modalidades de educação (educação de jovens e adultos, educação especial...), nem analisou os limites e possibilidade dos projetos pedagógicos de atender à expectativa que os pedagogos formados atuem nesses processos educativos específicos. Adicionalmente, sinalizou pouco sobre a questão dos estágios, sobre os mecanismos institucionalizados para sua realização, suas áreas temáticas, atividades desenvolvidas, entre outros aspectos.

Especificamente sobre o perfil do egresso da licenciatura em pedagogia, o Sinaes, por meio do Enade, revelou que os conteúdos considerados por ele como necessários à formação com qualidade do pedagogo não estão circunscritos ao art. 5. ${ }^{\circ}$ das DCN do curso (BRASIL, 2006b), tampouco têm inspiração nos conteúdos sugeridos pela prova docente ou nas experiências internacionais de avaliação da qualidade de cursos de formação de professores. O perfil de formação aferido por meio do exame de desempenho discente para o curso em questão não está focado em conteúdos que definem a profissionalidade do pedagogo na condução de classes da educação infantil e anos iniciais do ensino fundamental, tampouco na gestão de espaços escolares e não escolares, conforme ilustrado pelos resultados apresentados por Souza (2013). Essa realidade, aliada ao peso do NIDD que, em linhas gerais, é calculado a partir da comparação do desempenho dos alunos ingressantes no Enem e aqueles apresentados pelo grupo de concluintes na parte de formação geral do Enade (base para formação de qualquer profissional), pareceu sugerir o entendimento de que um curso de pedagogia de qualidade para o Sinaes tem uma função formativa genérica, sem adentrar nas especificidades da profissão.

Por fim, a análise combinada do CPC e da avaliação in loco permitiu considerar que a qualidade da formação do pedagogo no Brasil não pareceu ser determinada em torno das concepções teóricas de formação docentes. Apesar de conceitualmente haver maior frequência de uma concepção de formação que assume a prática como fato social, associada ao 
desenvolvimento pleno do pedagogo como profissional e cidadão, não foi possível assumir parametrizações em torno dessa concepção. Os dados revelaram apenas preocupações dos avaliadores com as práticas de docência e gestão educacional, sem que discussões epistemológicas em torno dessa prática se revelassem, nem no sentido de polarização teórica sugerida por Araújo (2009), nem no sentido de reciprocidade de perspectivas encontrada em Rios (2010). Há que se reforçar, ainda, que tais preocupações com a prática apareceram circunscritas ao conhecer-na-ação, embora tenham surgido elementos em torno da inovação ou do desenvolvimento do talento artístico profissional, presentes em Schön (2000).

Assim, os dados evidenciaram que o Sinaes não vem oferecendo referências objetivas para a organização didático-pedagógica de cursos de pedagogia no Brasil, mas tem fixado as características requeridas para o corpo de docentes e para a infraestrutura, supostamente, para atender a essa organização didático-pedagógica não parametrizada. Adicionalmente, tem sido capaz de hierarquizar os cursos em torno de seu padrão numérico, sem que seja possível identificar o perfil de qualidade dos cursos em todos os níveis da escala, tornando seus critérios pouco esclarecedores sobre o que se espera de um bom curso de pedagogia no Brasil.

\subsection{CRITÉRIOS DE QUALIDADE PRESENTES NA OFERTA DA LICENCIATURA PRESENCIAL EM PEDAGOGIA DO PARFOR}

O padrão de qualidade para a formação de professores da educação infantil e dos anos iniciais do ensino fundamental, aludido como princípio pelo decreto que dá sustentação ao Parfor (BRASIL, 2009a), assemelhou-se mais a um conjunto de sentidos sobrepostos, do que a um significado representativo daquilo que se espera da oferta de um bom curso presencial de pedagogia. As características que emergiram dos dados reportaram uma diversidade de parâmetros sobre o que se entendeu por qualidade entre os cursos do Parfor, sem que fosse possível observar a predominância de qualquer um deles em torno dos indicadores de projeto pedagógico dos cursos e sua inter-relação com o perfil dos egressos, estágios, atividades complementares, desenvolvimento e organização do curso, tratamento dos conteúdos curriculares e qualidade do corpo docente.

No que concerne à concepção de formação do pedagogo como docente também houve diferenças de percepções dos coordenadores sobre a configuração de um bom curso. Apesar disso, foi possível observar que a maior parte dos entrevistados (mas não a maioria absoluta) associou tal configuração a uma articulação entre teoria e prática, assim expressado em suas falas: 
[Nós temos no curso] numa perspectiva de reflexividade, [...] baseada mais numa racionalidade prática do que numa racionalidade técnica (Coordenador K)

Nós valorizamos a prática, mas a partir da prática nós procuramos oferecer a parte teórica para que tenha aí um equilíbrio entre teoria e prática. Não há valorização de uma ou de outra (Coordenador D).

[Temos] uma visão de que a teoria e a prática são indissociáveis. [...] A gente valoriza muito a questão da formação teórica do aluno, articulada a conhecimentos práticos, mas a concepção teórica aqui é muito bem consolidada (Coordenador N1).

Nesse sentido, tais falas pareceram reforçar a possibilidade da separação da concepção formativa em categorias, conforme apresentadas por Araújo (2009). Chamou, ainda, a atenção o fato de alguns coordenadores terem destacado a importância da formação teórica, fazendo uma espécie de contraponto na associação entre teoria e prática. Inclusive, um dos entrevistados destacou como concepção de formação docente do curso, justamente, a sólida base teórica, numa perspectiva de aproximação à racionalidade técnica ou de conhecer-naação, descrita por Schön (2000), conforme transcrito:

[uma vez] que existem certos conhecimentos que são necessários para a prática profissional, o curso tenta se esmerar na transmissão desses conhecimentos. $\mathrm{Na}$ medida em que ele consegue alcançar esse objetivo, contribui para o que se chama de profissionalização (Coordenador J).

Adicionalmente, esteve presente também nas falas dos coordenadores a concepção de formação docente na perspectiva de racionalidade crítica, nos termos definidos por Araújo (2009), a saber:

[Reforçamos] que a sua atuação em sala de aula [como professor] tem uma dimensão maior que a própria sala de aula. Então, aquilo que ele [desenvolver com] seus alunos [...] pode contribuir para os alunos irem além daquilo que se pensavam... Alfabetização não é só letramento, também é política (Coordenador P).

[Buscamos formar um] profissional crítico transformador. Que não tem receita, mas que observa, analisa e transforma a sociedade sempre para melhor (Coordenador Q).

Embora tais perspectivas, tratadas de forma diferenciada na teoria, não neguem existir uma relação de reciprocidade dialética entre elas, tal fato não pareceu permear a realidade dos cursos de uma forma consistente ou concatenada. A partir dos dados, emergiram ideias que pareceram reger o processo de formação docente no Parfor, sem que se pudesse garantir uma articulação ou consistência entre elas, individualmente, em cada um dos cursos, dentro da perspectiva plural (RIOS, 2010). Com isso, identificou-se um conjunto de sentidos em torno 
da concepção de formação docente, sem que tais sentidos pudessem ser articulados em torno de fundamentos basilares que apontassem, nesse aspecto, um significado da qualidade efetivamente compartilhado pelos cursos do Parfor.

De forma semelhante, na discussão sobre os projetos pedagógico dos cursos (PPC), foram valorizados tanto os formatos especialmente desenhados para atender à demanda da formação de professores em serviço - por meio de projetos inovadores nunca testados como também a reprodução de projetos pedagógicos reconhecidos como de qualidade pelos processos avaliativos do Sinaes. Nesse caso, os sentidos de qualidade colocaram lado a lado projetos experimentais que visavam articular a teoria e a prática, além da pesquisa como elemento de construção do saber docente e da interdisciplinaridade no processo formativo, com projetos testados e aprovados, mesmo que, em tese, menos adequados à proposta de formação de professores em serviços uma vez que não foram originalmente criados para isso. O sentido estrito da qualidade buscada pelo PPC no Parfor, então, pareceu sobrepor, sem a devida articulação, projetos inovadores ainda não avaliados e projetos já testados, mas com espaço, segundo os próprios coordenadores, de serem aperfeiçoados.

Em decorrência dessa realidade, observou-se entre os cursos analisados uma diversidade na definição do perfil do egresso formado pelo curso, bem como a concepção de docência a ele associada entre os diversos projetos. Dessa forma, os dados revelaram que quando os coordenadores assumiram um projeto pedagógico diferente do curso regular (sete casos na amostra de 17 entrevistados), o perfil de formação do egresso revelou-se voltado à atuação na educação infantil e anos iniciais do ensino fundamental, conforme relatado pelos coordenadores:

O foco do nosso curso de pedagogia é a docência dos anos iniciais e educação infantil. (Coordenador A)

[Formamos] pessoas que vão atuar principalmente no ensino [e não] em outros cargos [como os] de gestão ou de supervisão. (Coordenador D)

[Formamos para o] exercício do magistério na educação infantil, nos anos iniciais do ensino fundamental, e na educação de jovens e adultos (Coordenador E).

[No nosso curso,] o professor sai com uma formação integral para atuar na educação infantil e nas séries iniciais com autonomia para tomar decisões (Coordenador F).

Nós somos um curso de licenciatura em pedagogia que tem como eixo principal a docência na educação infantil e nos anos iniciais e abordamos alguns aspectos relacionados à gestão (Coordenador $\mathrm{G}$ ).

A prioridade é trabalhar as habilidades necessárias para essa formação docente para gerar realmente competência e essa mudança na educação (Coordenador M).

[Formamos] o professor para dar aula. Ele não está sendo formado para ser gestor. É para ser professor... [...](Coordenador P). 
Apenas um dos coordenadores, entre aqueles que afirmaram possuir PPC nas turmas do Parfor diferente daquele das demais turmas, revelou que o perfil do egresso do curso agregava a preparação do gestor, e não só o docente. Em uma perspectiva de docência ampliada, esse coordenador destacou que seu curso prepara o egresso "para atuar em séries iniciais, na educação infantil e nos processos de gestão" (Coordenador K).

Os demais coordenadores $(n=9)$, que declararam que as turmas do Parfor seguiram os mesmos projetos pedagógicos do curso regularmente oferecido pela IES, indicaram o perfil do egresso por meio da sua atuação em sala de aula, associada à gestão em espaços escolares e não escolares, conforme explicitaram:

O foco da atuação [dos] alunos [é o trabalho nas] séries iniciais, educação infantil e gestão (Coordenador B).

[Formamos] professores para atuar na educação infantil, ensino fundamental e gestão (Coordenador C).

[Buscamos] uma formação [competente], em termos de atitude, de formação intelectual, de visão da conduta profissional (Coordenador $\mathrm{H}$ ).

O foco é a educação infantil e os anos iniciais, embora a pedagogia tenha no seu plano [também a] gestão [...] (Coordenador I).

O pedagogo que nós formamos [tem] a docência como base. Mas o curso se preocupa e forma também para o apoio escolar (Coordenador J).

[Atuamos] em quatro grandes frentes de trabalho da educação: educação infantil, o ensino fundamental, incluindo EJA, a gestão escolar e a gestão de ambientes não escolar e popular (Coordenador L).

A gente forma aqui para educação infantil, para os anos iniciais e para a gestão escolar (Coordenador N1).

[Formamos] o professor da educação infantil [e fundamental], com possibilidade de atuação em gestão, (Coordenador N2).

[Visamos a] formação de professores para educação infantil, anos iniciais do ensino fundamental; EJA e educação especial, com estágio inclusive, e a gestão escolar (Coordenador Q).

Essas diferenças nas propostas de perfil de atuação dos egressos, evidenciadas pelas falas dos coordenadores, puderam ser associadas, por um lado, à proposta do Parfor de fazer a formação em serviço de professores, mas também à pouca clareza sobre a identidade profissional do pedagogo expressada pelas DCN do curso. Se por um lado, o texto desse documento legal garantiu que a base de formação do pedagogo é a docência, por outro, não pareceu garantir que essa docência fosse aquela identificada por Aguiar et al. (2006) em seu sentido amplo, a qual deve concatenar as duas pontas da formação do pedagogo - professor e especialista em educação. 
As diretrizes da licenciatura em pedagogia foram construídas sob a base de um curso historicamente criado para atender à formação de especialistas em educação, conforme estabeleceu o Decreto-Lei n. ${ }^{\circ} 1.190$, de 4 de abril de 1939, que criou o curso no país (BRASIL, 1939). Porém, na oferta do Parfor Presencial não se garantiu que a formação do docente levasse em consideração a necessidade de conhecimento de gestão da educação em espaços escolares e não escolares. Assim, apesar da proposta da docência ampliada, as diretrizes curriculares foram apropriadas, por parte dos cursos de pedagogia do Parfor, a partir da docência stricto sensu, entendida como ato de ministrar aulas, sem agregar as atividades de organização e gestão de sistemas e instituições formais e não formais de educação.

Tal realidade evidenciada pelos dados da pesquisa pareceu ter reforçado os alertas de Libâneo (2006), Pimenta, Franco e Libâneo (2010), e até mesmo de Rodrigues e Kuenzer (2007) de que a proposta de docência ampliada, sintetizada nas diretrizes da licenciatura em pedagogia, poderia reduzir o curso em questão à docência stricto sensu, esvaziando-o. Alguns coordenadores assim ponderaram sobre essa questão:

O Conselho deliber[ou] uma coisa escandalosa, para fragilizar e fragmentar a formação dos professores. A formação vai sendo precarizada em vez de proporcionar uma solidez no aspecto teórico, de habilidades e valores em cada tipo de formação. Embora esse seja o projeto pedagógico do meu curso, não vou te dizer que ele esteja bem elaborado [...] Por que o curso vai para três frentes de formação? Porque a maldita diretriz foi aprovada e ofereceu isso e muito mais no sentido de fragilizar a formação desses profissionais. O que nós fizemos, a contra gostos, foi adotar essa diretriz que sabiamente, ou perversamente, foi definida. (Coordenador N2).

O que significa ser pedagogo?... Todo o debate da área passa por essa concepção. Eu acredito que não esteja ainda suficientemente claro em termos de área. [...] Só que [evidentemente] os alunos encontram certos limitadores de como o reconhecimento dessa profissão ou dessa formação será [feita] para ocupar alguns cargos. Aí nós entraríamos em outra discussão [...] Quando os alunos me perguntam em gestão e supervisão: 'professora, mas na escola que eu atuo, por exemplo, a legislação municipal, o regimento diz que para ser diretor de escola eu tenho que ter uma graduação e não importa se ela é na área da pedagogia ou não'. Aí cai por terra aquela discussão de que talvez eles sigam fazendo uma especialização na área ou posteriormente [...] Eu não estou indo aqui contra ou a favor de eleição. Não é isso... Mas é essa confusão em torno da identidade da área também faz com que alguns campos de atuação se enfraqueçam, por mais que se fale que alguns lugares, por excelência, são lugares para pedagogos. [...] A opção foi por um foco forte da docência para a educação infantil e uma especialização posterior em gestão e supervisão. [...]. Essa opção foi feita em função das diretrizes [...] (Coordenador A).

Esses fragmentos das falas de coordenadores de cursos de pedagogia do Parfor trouxeram aspectos relevantes que não estão sendo adequadamente discutidos no âmbito da política de formação docente, nem dos processos regulatórios desses cursos, a saber: a organização da formação inicial do docente numa perspectiva continuada; a profissionalidade 
do pedagogo em sua relação com a organização do trabalho escolar; e a própria organização dos cursos de pedagogia em função das discussões anteriores.

A perspectiva de dualidade presente no perfil dos pedagogos formados pelo Parfor pareceu ilustrar uma necessidade de a área ampliar as discussões em torno da formação inicial, integrando-a à formação continuada. Dados presentes em relatórios de organismos internacionais (OCDE, 2011) indicam uma tendência de organização sequenciada da formação docente ao redor do mundo, o que pareceu sugerir uma alternativa à discussão dicotômica estabelecida para o perfil do pedagogo. Exemplos práticos dessa articulação entre formação inicial e continuada também puderam ser observados, no contexto desta pesquisa, em cursos como administração e medicina que mantêm uma identidade, independentemente do perfil diferenciado de atuação profissional assumido por seus egressos.

Conforme relatos, a organização do trabalho escolar também apareceu afetada por essa dualidade ainda presente nos perfis do egresso do curso de pedagogia. Adicionalmente, a inexistência de requisitos formativos para o exercício de atividades administrativopedagógicas no âmbito escolar pareceu enfraquecer os argumentos em prol desses conteúdos apenas nos cursos de pedagogia, ficando as demais licenciaturas fora de sua abordagem. Nesse sentido, os dados sugeriram uma perspectiva de aprofundamento da discussão da docência ampliada no que tange aos seus reflexos não só no processo formativo docente, mas também na qualidade do trabalho escolar.

Nesse sentido, tanto a conexão entre a formação inicial e continuada quanto os impactos formativos na dinâmica da gestão escolar pareceram afetar diretamente a organização didático-pedagógica. Conforme foi possível depreender das falas dos coordenadores, há uma preocupação real e fundamentada de alguns cursos presenciais de pedagogia do Parfor em torno dos reflexos da dualidade do perfil formativo dos seus egressos sobre a qualidade do curso.

Há que se ressaltar, no entanto, que, para outros coordenadores, a perspectiva de docência ampliada e de possíveis dualidades nesse perfil formativo não se reverteu necessariamente como um problema concreto, como deixaram entrever:

As diretrizes tem essa determinação. Toda a nossa reflexão, toda a programação prepara, o colegiado do curso. A gente faz o máximo possível para contemplar as diretrizes. Porque a gente acredita... Todo o esforço do colegiado do curso vai no sentido de formar aquele profissional, atendendo as diretrizes (Coordenador C).

O bom gestor [...] é um bom professor. O bom professor é um bom gestor. Do ponto de vista dos conhecimentos que ele tem nas especificidades por meio das disciplinas e estágios voltados para esse conteúdo. Então, nós entendemos que estamos de certa 
forma com a qualidade necessária para que ele, indo para uma área ou outra, consiga lidar com as especificidades do cotidiano (Coordenador J).

A nossa ênfase é na formação do professor, mas a gestão está inserida nesse contexto e que faz parte da formação do professor. A gente tem conseguido distribuir bem (Coordenador Q).

Grande parte dos coordenadores, porém, não se posicionou ante a possibilidade de a docência ampliada não solucionar adequadamente o perfil do egresso do curso entre o pedagogo-professor e o pedagogo-especialista. Para eles, tal questão foi relacionada a aspectos desconexos do curso, tais como a competência profissional do professor-formador do curso do Parfor como um especialista na sua área de atuação, passando pela atuação dos gestores municipais na liberação dos professores-aprendizes para realizar o curso do Parfor e indo até as práticas de alguns dos alunos como gestores na sua atuação profissional. Todavia, entre aqueles que não se posicionaram em relação à docência ampliada, muitos resumiram a questão a uma dificuldade de tempo para atender à proposta, sem entrar no mérito sobre sua adequação ou não:

Tive dificuldade em trabalhar com essa perspectiva de docência ampliada. Principalmente quando eram três anos. Agora que são quatro anos, isso melhorou um pouco. [...] É muita exigência para tão pouco tempo (Coordenador B).

[Os alunos] são mais preparados para a educação infantil e anos iniciais. Há o estágio de gestão e eles têm uma disciplina de gestão e um estágio. Ali é um tempo curto, embora tenha a disciplina de políticas educacionais e legislação (Coordenador I).

Então, a gente faz uma crítica de que é muita coisa para a gente trabalhar com o nosso aluno: aspectos do desenvolvimento da educação infantil; aspectos das metodologias e dos conteúdos e aspectos da coordenação e gestão e, querendo ou não, terminam entrando os aspectos da supervisão. $\mathrm{O}$ nosso aluno é formado para essas três frentes e o do Parfor também (Coordenador N1).

Em função da diversidade de perfis identificados para a atuação dos egressos, a organização didático-pedagógica dos cursos analisados terminou por refleti-los, sem que fosse possível identificar um sentido único para essa qualidade. Do ponto de vista dos estágios, identificou-se uma variedade de áreas para o seu desenvolvimento, entre as quais sempre estiveram presentes as áreas de educação infantil e ensino fundamental, conforme sugeriram as DCN do curso. Chamou positivamente à atenção, ainda, a possibilidade de estágios específicos nas áreas de educação de adultos e educação especial em um dos cursos observados. Também se destacou na realidade de alguns casos a possibilidade de os estágios na área de gestão se dividirem em espaços escolares e não escolares, enquanto que, em outros, a área de gestão inexistia como opção para o exercício da prática profissional. 
No que se refere às dinâmicas de condução desses estágios, encontrou-se uma grande variedade de organização entre os cursos. Todas elas foram declaradas pelos coordenadores como voltadas à formação com qualidade do pedagogo. As práticas de estágios podiam se refletir: (i) em observações empíricas, seguidas de discussão em sala de aula; (ii) em pesquisa com geração de relatório; (iii) em projeto de aprofundamento teórico e intervenção ou, até mesmo, (iv) em experiência de exercício profissional, conforme previu o inciso IV do art. $8 .^{\circ}$ das DCN do curso.

Já em relação à obrigatoriedade dos estágios, na maior parte dos casos, os coordenadores afirmaram dispensar, nos termos legais, o aluno do estágio naquela área em que ele estava atuando, exigindo a carga horária completa apenas nos casos em que o professor-aprendiz não estava em atuação como gestor ou como professor em turmas de nível diferente. Por outro lado, em pelo menos dois dos modelos de estágio exigiram a efetiva participação dos professores-aprendizes, a despeito da possibilidade de dispensa legal. Como justificativa para essa não dispensa, os coordenadores desses cursos argumentaram que o momento de estágio se configurava oportuno para que o aluno pudesse refletir sobre o trabalho que vinha desenvolvendo no seu cotidiano como professor da educação básica. No entanto, em um desses casos, se exigiram estágios apenas naqueles níveis para os quais os alunos estavam em atuação em sala de aula, dispensando-os dos demais.

Como foi possível depreender, as experiências de estágios ocorreram das formas mais variadas sem que, necessariamente, o aluno tivesse assumido uma sala de aula ou exercido uma atividade vinculada à orientação pedagógica, à direção escolar, bem como ao desenvolvimento de práticas educativas ou de planejamento em ambientes não escolares. Além disso, tais experiências ocorreram tanto sob a supervisão direta de um professor no espaço escolar quanto de forma mais remota com a apresentação de relatórios ou documentos comprobatórios de determinadas atividades. Em alguns casos, as experiências de estágio foram compartilhadas por meio de seminários, nos quais houve apresentação e debate das experiências adquiridas por meio de trabalho de investigação, estudo de caso ou outra atividade. Ressaltou-se, ainda, que, independentemente da forma como os estágios foram tratados entre os cursos da amostra, eles foram defendidos como adequados à concepção de qualidade identificada - formação teórica sólida, voltada para a reflexão crítica e transformadora da prática.

Em termos institucionais, encontraram-se estágios organizados por meio de ações colaborativas dos professores-aprendizes com escolas nas quais atuavam como professor ou em outras escolhidas em acordo com as IES. Nesse aspecto, chamou a atenção a pouca 
incidência de convênios firmados entre as instituições ofertantes dos cursos e os espaços de realização do estágio, independentemente do fato de os alunos serem também professores da educação básica. Mesmo porque, em alguns casos, a situação do aluno-professor não garantiu tranquilidade do curso para a organização das experiências de exercício profissional, tendo em vista a precariedade dos contratos desses discentes com as redes públicas de educação básica, conforme relatou um dos coordenadores:

Eles têm uma semana de intensivo, [momento em que] vão os professores [formadores] acompanhando[-os] para evitar problemas políticos. Os professores que estão em sala de aula não estão deixando os outros [antigos, atuais alunos do Parfor] fazerem o estágio. Então, o último encontro é um grande seminário onde se avalia o trabalho apresentado e as dificuldades encontradas. [Ocorrem] em mesas redondas e palestras para a própria comunidade do município (Coordenador F).

No que se referiu ao tratamento dado aos conteúdos curriculares, as informações prestadas pelos coordenadores confirmaram o diagnóstico apresentado por Gatti (2012) de que os cursos do Parfor pouco inovam. Para a autora, inovação pode ser entendida como a superação das “divisões clássicas entre tópicos e subtópicos disciplinares [...] por uma concepção de ensino mais integradora, e quando a proposta didática se apoia em meios diferenciados de ensino" (GATTI, 2012, p.10). Operacionalmente, tais inovações se materializariam, na visão da autora, por meio de: i) estrutura curricular em módulos temáticos e não módulos disciplinares, ou disciplinas, evitando-se a multiplicação de conteúdos fracionados; ii) metodologias de problematização; iii) utilização de metodologias de caso e incidentes críticos; ou, iv) oficinas com propósitos integradores de conhecimentos e práticas. Considerando essa categorização, apenas foi possível identificar propostas inovadoras em três casos, conforme expressaram:

O currículo integrado é assim, nós não partimos da teoria, para depois ir para a prática. [...] Por exemplo, em vez de a gente ter aquelas disciplinas fragmentadas como história da educação, sociologia, [...] nós estudávamos a nossa história local até chegar lá na Grécia antiga. Então, assim, relacionava a teoria e a prática desde o primeiro semestre e rompia com essa fragmentação da disciplina colocando blocos [...]. (Coordenador B).

Estruturamos em oito blocos, mas agregamos esses blocos no que a gente chama de fundamentos sociológicos da educação; fundamentos filosóficos da educação (fundamentos metodológicos estão aqui); fundamentos psicológicos; fundamentos históricos; fundamentos político-administrativos; disciplinas da área pedagógica pedagogia e didática e os ensinos; planejamento e avaliação; e, áreas conexas (educação especial, etc.). [...] Tem a prática e pesquisa (Coordenador E).

O curso é organizado por eixos e cada eixo tem alguns módulos. [...] No primeiro eixo, de contextualização, [...] nós tivemos um módulo que chamamos de fundamento da educação. Dentro desse módulo, vários professores trabalharam, 
procurando abordar os fundamentos da educação. Procurando estabelecer um diálogo entre os aspectos relacionados à história da educação, sociologia, filosofia, antropologia [...] (Coordenador G).

Os coordenadores também foram questionados sobre a qualidade do curso refletida por meio das atividades [curriculares] complementares (ACC). No entanto, o conjunto dos relatos fez emergir uma concepção de ACC como espécie de apêndice do processo de formação, utilizada como espaço para suprir deficiências de formação da educação básica oficinas de interpretação de texto, desenvolvimento da habilidade de escrita e até mesmo alfabetização digital - ou como a prática inerente à articulação das disciplinas teóricas com a realidade educacional. Em alguns casos, as atividades complementares foram apresentadas inclusive com propósito de aprofundamento teórico - e não prático, como definido nas DCN consistindo em fichamentos de livros, presença em aulas inaugurais e participação em cursos de curta duração, conforme alguns trechos ilustrativos apresentados a seguir:

\footnotetext{
Nós temos uma programação intensa que os alunos interessados podem se inscrever. [Algumas] sem custo, outras não [...] Aula inaugural, abertura do semestre [...] Um pouco isso (Coordenador A).

Participação em eventos, trabalho voluntário na área de educação; leitura de alguns livros indicados pelos professores, filmes que fazem parte do conteúdo. Projetos de extensão, de pesquisa [...] (Coordenador D).

Seminário interno focando questões relativas ao trabalho deles. Qualquer atividade realizada. Seminários, colóquios, semanas [...] (Coordenador N2).

A gente oferece palestras, cursos e semanas de estudos em pedagogia, aula inaugural, [além de] grupos de estudo, de pesquisa e de projeto de extensão [...]. Fora da universidade, os alunos podem fazer cursos. Nem todos os cursos são aceitos, [depende de] com quem ele é feito, onde ele é feito. [...] Pode desenvolver atividades de teatro música. Tudo que envolve atividades acadêmicas e também culturais (Coordenador Q).
}

Tais relatos demonstram, de forma contextualizada, a proposta pouco clara das DCN da licenciatura em pedagogia sobre as ACC e sua relação com as atividades teórico-práticas, bem como na sua relação com as demais práticas previstas no documento legal - estágio e práticas de docência e gestão educacional. Conforme definido no inciso III do art. $7 .^{\circ}$ das referidas diretrizes, as atividades teórico-práticas precisam ser individualizadas e sistematizadas no currículo dos cursos, de forma a integralizar 100 horas, correspondendo às atividades de iniciação científica (IC), de extensão e de monitoria. Embora nas DCN não haja uma posição explícita sobre os objetivos de tais atividades, foi possível entendê-las como uma oportunidade - diferenciada da prática do estágio - para que os alunos pudessem aprofundar conhecimentos em campos específicos da educação, entre outros, educação especial, indígena, 
etc. Além disso, segundo o que está escrito, para cumprir a carga horária prevista para as atividades teórico-práticas deveriam contemplar, obrigatoriamente, os três aspectos previstos (IC, monitoria e extensão), uma vez que o conector utilizado é o “e”, não “ou".

Para melhor visualização dessas disposições legais, sintetizou-se na Figura 3, a seguir, os principais trechos contidos nas DCN do curso sobre esse tema. A partir dela, foi possível entender mais claramente a posição de Gatti (2012), que compreendeu as atividades complementares como atividades integradoras entre a teoria e a prática, mas observou também que sua denominação nos currículos dos cursos de pedagogia Parfor é vaga.

Figura 3 - Transcrição dos arts. $7 .^{\circ}$ e 8..$^{\circ}$ das DCN da licenciatura em pedagogia

\begin{tabular}{|c|c|}
\hline Artigo & Transcrição \\
\hline $\begin{array}{l}\text { Art. } 7^{\circ} \\
\text { Inciso } \\
\text { III }\end{array}$ & $\begin{array}{l}100 \text { horas de atividades teórico-práticas de aprofundamento em áreas específicas de interesse dos } \\
\text { alunos, por meio, da iniciação científica, da extensão e da monitoria. }\end{array}$ \\
\hline $\begin{array}{l}\text { Art. } 8^{\circ} \\
\text { Inciso } \\
\quad \text { II }\end{array}$ & $\begin{array}{l}\text { [a integralização de estudos será efetivada por meio de] práticas de docência e gestão educacional } \\
\text { que ensejem aos licenciandos a observação e acompanhamento, a participação no planejamento, na } \\
\text { execução e na avaliação de aprendizagens, do ensino ou de projetos pedagógicos, tanto em escolas } \\
\text { como em outros ambientes educativos. }\end{array}$ \\
\hline $\begin{array}{l}\text { Art. } 8^{\circ} \\
\text { Inciso } \\
\text { III }\end{array}$ & $\begin{array}{l}\text { [a integralização de estudos será efetivada por meio de] atividades complementares envolvendo o } \\
\text { planejamento e o desenvolvimento progressivo do Trabalho de Curso, atividades de monitoria, de } \\
\text { iniciação científica e de extensão, diretamente orientadas por membro do corpo docente da instituição } \\
\text { de educação superior decorrentes ou articuladas às disciplinas, áreas de conhecimentos, seminários, } \\
\text { eventos científico-culturais, estudos curriculares, de modo a propiciar vivências em algumas } \\
\text { modalidades e experiências, entre outras, e opcionalmente, a educação de pessoas com necessidades } \\
\text { especiais, a educação do campo, a educação indígena, a educação em remanescentes de quilombos, } \\
\text { em organizações não-governamentais, escolares e não-escolares públicas e privadas. }\end{array}$ \\
\hline $\begin{array}{l}\text { Art. } 8^{\circ} \\
\text { Inciso } \\
\text { IV }\end{array}$ & $\begin{array}{l}\text { [a integralização de estudos será efetivada por meio de] estágio curricular a ser realizado, ao longo } \\
\text { do curso, de modo a assegurar aos graduandos experiência de exercício profissional, em ambientes } \\
\text { escolares e não-escolares que ampliem e fortaleçam atitudes éticas, conhecimentos e competências } \\
\text { [na] Educação Infantil e nos anos iniciais do Ensino Fundamental, prioritariamente; nas disciplinas } \\
\text { pedagógicas dos cursos de Ensino Médio, na modalidade Normal; na Educação Profissional na área } \\
\text { de serviços e de apoio escolar; na Educação de Jovens e Adultos; na participação em atividades da } \\
\text { gestão de processos educativos, no planejamento, implementação, coordenaçâo, acompanhamento e } \\
\text { avaliação de atividades e projetos educativos; em reuniões de formação pedagógica. }\end{array}$ \\
\hline
\end{tabular}

Fonte: Resolução CNE/CP n. ${ }^{\circ}$ 01, 15 de maio de 2006 (BRASIL, 2006b).

Mesmo diante dessa pouca clareza das DCN da licenciatura em pedagogia sobre as ACC, elas puderam ser entendidas como uma das possibilidades de integralização curricular, estando associadas às atividades teórico-práticas - monitoria, IC e a extensão, que juntas integram cem horas de curso - e ao TCC -, cuja carga horária não foi previamente estabelecida, mas deve estar contemplada entre as 2.800 horas de atividades formativas definidas para o curso, nos termos do inciso I do art. 8..$^{\circ}$ das DCN da pedagogia (BRASIL, 2006b). Seguindo essa perspectiva de análise, entendeu-se que as atividades complementares 
visam proporcionar, no seu conjunto, vivências em modalidades e experiência educacionais variadas aos alunos e não se confundem com as práticas de docência e gestão educacional.

Práticas de docência e gestão educacional se materializam, então, como um quarto conjunto de práticas - os três primeiros conjuntos de práticas foram denominados de: i) atividades teórico-práticas; ii) estágios; e iii) ACC. Conforme definido no art. 8. ${ }^{\circ}$, inciso II, das DCN da licenciatura da pedagogia, esse quarto conjunto de práticas deve permitir a integralização curricular que propicie "aos licenciandos a observação e acompanhamento, a participação no planejamento, na execução e na avaliação de aprendizagens, do ensino ou de projetos pedagógicos, tanto em escolas como em outros ambientes educativos" (BRASIL, 2006b).

Essa interpretação, no entanto, não se refletiu na realidade encontrada na oferta presencial de pedagogia do Parfor. O que se percebeu foi que as práticas de docência e gestão educacional, assumidas nesta pesquisa como atreladas às disciplinas teóricas como o seu componente prático, foram entendidas como atividades complementares. Por sua vez, entendendo-se as práticas de docência e gestão educacional como atividades complementares, surpreendentemente, estas passaram a se refletir na fala dos coordenadores como detentoras da obrigatoriedade de totalizar carga horária de cem horas. Por consequência, as atividades teórico-práticas originalmente previstas nas DCN do curso, como Monitoria, IC e Extensão, ficaram descaracterizadas, inclusive na sua natureza de possuir carga horária específica e obrigatória voltada ao tratamento de conteúdos específicos do campo da educação. Nesse contexto, confuso, em que uma prática foi tomando o lugar legalmente previsto para outra, o trabalho de conclusão de curso, definido expressamente pelas DCN como atividade complementar, não foi referenciado por parte dos coordenadores em seu relato sobre a qualidade dos cursos coordenados por eles, conforme informaram:

[...] diversas oficinas pedagógicas são computadas como ACC. No início do curso, [os alunos] recebem uma lista com o que pode ser agregado de ACC, [por exemplo:] experiências em conselhos escolares, em espaços não escolares, em gestão [...]. Aí eles são orientados a cumprir 200 horas [dessas atividades] (Coordenador E).

[...] então eu posso estar em sala de aula por 50 horas e colocar 10 horas como atividades complementares: uma visita à escola, uma visita técnica, ou um filme. Ou então, a experiência de algum assentamento. Alguma experiência de espaço não formal. O professor tem a liberdade de criar essa atividade [...] (Coordenador M).

É preciso reconhecer, no entanto, que essa confusão em torno das atividades complementares se deve à forma como o TCC e as atividades de monitoria, de iniciação científica e de extensão foram associados pelo inciso III, art. 8..$^{\circ}$ das Diretrizes da pedagogia 
(BRASIL, 2006b) “às disciplinas, áreas de conhecimentos, seminários, eventos científicoculturais, estudos curriculares de modo a propiciar vivências em algumas modalidades e experiência". Tomadas dessa forma, aparentemente as cem horas de atividades teóricopráticas, exigidas pelas DCN da licenciatura em pedagogia, foram entendidas por alguns dos cursos como práticas de docência e gestão educacional (complementando carga horária teórica das disciplinas teóricas) ou como vivência em algumas modalidades ou experiências (atividades complementares), conforme expresso nas falas anteriormente transcritas e nesta a seguir:

Então cada professor de cada disciplina, de acordo com os critérios préestabelecidos e fixados no projeto pedagógico do curso, vai passar as atividades que eles têm que desenvolver, articulando-as às disciplinas. Além disso, tem ACC que são atividades culturais que também estão especificadas no projeto pedagógico e são acompanhadas por um professor do curso. Eu tenho um professor responsável para cuidar dessas atividades complementares (Coordenador C).

De qualquer forma, essa pouca clareza da norma não foi capaz de explicar como as atividades complementares se reverteram, no contexto de alguns cursos de pedagogia do Parfor, em oficinas ou atividades para a recuperação de deficiência de formação básica dos alunos (português, informática, produção de texto, etc.). Sem se questionar a necessidade ou adequação de tais oficinas, identificou-se apenas o fato de que tal procedimento não pareceu estar formalmente amparado nas DCN do curso, uma vez que não possuem vinculação específica aos núcleos de estudos que definem o currículo previsto no art. $6 .^{\circ}$ das referidas normas (BRASIL, 2006b). Ainda assim, esses conteúdos relativos à formação no ensino médio estão ocupando a carga horária obrigatória de um curso de nível superior, conforme evidenciado por alguns coordenadores:

Outra [atividade] que a gente fez foi [promover] oficinas à medida que percebíamos que era necessário [...]. Então, uma das oficinas que tivemos foi a de informática, tivemos várias de escrita, e agora no final do curso teremos que fazer novamente [...] (Coordenador G).

Eu criei, para atender as atividades complementares dos projetos pedagógicos, oficinas pedagógicas de informática, elaboração de resenhas, resumos, principalmente de pesquisa, cinema na escola, brinquedoteca, jogos didáticos e inglês. [...] Nas atividades complementares, eu faço as oficinas pedagógicas. Que são complementares mesmo. Essa de elaboração de texto... Cinema na escola, jogos didáticos, informática. Então, a gente dá esses complementos, que são na maioria 20 horas a carga horária de cada uma dessas (Coordenador P).

Apenas para ilustrar as possibilidades que poderiam ser assumidas em torno dos conteúdos complementares, que não apenas a recuperação dos alunos em conhecimentos 
próprios da educação básica, destacaram-se as sugestões de Gatti (2012), a saber: oficinas para elaboração de materiais didáticos; oficinas voltadas ao pensamento lógico-matemático; estudos sobre a dimensão ético-política da prática docente; didática e currículo da educação básica, diversificada por área e nível; atividade de experiência social na comunidade do entorno escolar; questões de escolas urbanas, suburbanas e rurais; análise qualitativa da instituição escolar; saber específico da área e seu papel no currículo escolar; desenvolvimento de atividades de planejamento de ensino; planejamento do trabalho escolar; construção e experimentação de projetos de ensino; e diferenciais cognitivos entre crianças e adolescentes.

Em relação ao desenvolvimento e organização do curso, também se encontrou um movimento dialético naquilo que foi considerado como facilitador ou inibidor da qualidade da oferta dos cursos de pedagogia do Parfor Presencial. Embora a questão da experiência prática dos alunos tivesse sido destacada na quase unanimidade das falas dos coordenadores, não se observou consenso sobre o impacto de tal característica dos alunos para a qualidade do curso. Por um lado, a proximidade com a sala de aula foi muito elogiada como oportunidade maior de apropriação dos conteúdos teóricos discutidos. Por outro, não deixou de ser vista como barreira à própria profissionalização do professor-aprendiz, conforme expuseram alguns coordenadores entrevistados:

\footnotetext{
Essas professoras têm contato diário com a sala de aula, com a gestão escolar. Muitas delas já foram diretoras ou são diretoras de escolas, sem ter curso de pedagogia, sem dominar os conteúdos científicos, históricos, filosóficos da pedagogia. [...] É mais fácil incorporar o conteúdo a um professor que não atuou em escolas do que aquele que cristalizou processos e conhecimentos não científicos e do senso comum na prática do seu cotidiano. Aí a dificuldade é maior (Coordenador P).

Os alunos do Parfor são professores que já têm experiência. Algumas experiências que a gente manifesta na prática como portadores de vícios, mas outras também portadoras de virtudes. A gente também não pode desconhecer essa condição (Coordenador K).
}

As repercussões da realidade do aluno com experiência docente se refletiram ainda em cuidados quanto à periodicidade da oferta, à metodologia de trabalho e aos demais aspectos envolvidos na organização do curso. Sobre a periodicidade na oferta, em boa parte dos cursos, as aulas se concentraram nos meses de janeiro e julho, finais de semana e à noite. Outra parte menor de cursos manteve sua rotina regular de oferta de disciplinas, sem que se pudesse constatar o impacto de um ou outro procedimento sobre a evasão ou a reprovação de alunos para que se pudesse considerá-los como adequados, ou não, em relação às diversas realidades presentes no Brasil. 
Contudo, alguns coordenadores de cursos localizados principalmente na Região Norte revelaram que, além de ser necessária a alteração do período da oferta de disciplina, a questão do planejamento do cronograma de aulas apareceu como imprescindível para garantir a presença dos alunos nos dias de aula. Pelo menos um coordenador da Região Norte e um da Região Nordeste apontaram expressamente a necessidade de que as atividades teóricas se limitassem à carga horária presencial prevista: todas as leituras e exercícios propostos deveriam ser realizados exclusivamente no período das aulas, sob a supervisão do professor. No entanto, as repercussões desse procedimento na qualidade da formação de um estudante da educação superior não ficaram claras, tampouco se a permanência dos estudantes no curso seria um indicador de qualidade mais importante do que o desenvolvimento de sua autonomia intelectual propiciada pelos momentos de reflexão individual. Os relatos desses casos pareceram se reportar mais à conveniência dos estudantes do que efetivamente a uma contribuição ao processo de crescimento deles como profissionais, como seguem:

Evitamos fazer trabalhos em casa. Eles fazem em sala de aula com o professor (Coordenador F).

Por isso que eu falei com você, [o professor] tem que ler com o aluno, para que o aluno possa começar a ler. [...] Cada disciplina é uma semana. Nós pedimos para que o professor trabalhe na semana tarefas obrigatórias. Para casa, os alunos não cumprem. [...] Alguns têm muita dificuldade e outros o tempo realmente não dá. Eles precisam ir de barco para chegar as suas casas. Quando chegam é sábado de noite, domingo. [...] Então, a qualidade para mim, envolve tudo isso (Coordenador $\mathrm{P})$.

Destacou-se, no entanto, certo consenso na afirmação de que as deficiências de formação básica apresentadas pelos alunos da pedagogia do Parfor não se distanciavam muito das deficiências apresentadas pelos alunos regulares dos cursos:

[...] Eu fiz algumas avaliações, semelhantes ao Enade, entre alunos do Parfor e do não Parfor. Com isso, nós verificamos que esses alunos [do Parfor] não têm diferenças dos demais. Isso ajudou bastante. A partir daí nós fomos criando mecanismos de trabalhar as defasagens do curso como um todo [...] Como a pesquisa é um levantamento que se faz todo semestre nós conseguimos verificar que não existem diferenças entre os alunos do Parfor para os demais alunos (Coordenador B).

Os problemas de formação básica são idênticos [...] Problemas de escrita, concordância, plágio, todos iguais. Lá e cá. [Parece-me] que isso vai além da especificidade desse curso: envolve condições sociais mais amplas (Coordenador J).

Eu acho que isso não é um privilégio do Parfor pedagogia não. É um privilégio da Universidade. Muitos de nossos alunos não sabem ler. [Quando] digo, não sabem ler, eu falo da leitura interpretativa, da leitura crítica (Coordenador P). 
As principais diferenças reportadas para justificar tratamentos diferenciados entre as turmas do Parfor e as demais foram localizadas no cansaço proveniente de alunos trabalhadores; no tempo de afastamento mais tempo da rotina de estudo; na maior dificuldade no uso da tecnologia da informação; nas responsabilidades familiares mais pesadas; e no menor tempo disponível para participação das atividades extras propostas. Em síntese, puderam-se resumir as diferenças em torno da idade mais avançada dos alunos do Parfor, associada a todas as virtudes e limitações impostas por ela, quando comparadas às dos alunos mais jovens, em maior número dos cursos regulares.

Adicionalmente, pouco se pôde inferir sobre as repercussões do processo de avaliação de aprendizagem na organização das turmas do Parfor em relação às demais turmas do curso. As experiências compartilhadas apresentaram como modus operandi em caso de reprovação, desde a participação do aluno do Parfor em outras turmas do curso regular, passando pela avaliação em várias etapas para evitar a reprovação e indo até a participação do aluno em turmas do Parfor oferecidas pelas IES, podendo inclusive ser em outra área de licenciatura.

Observou-se também certa tendência entre os coordenadores de considerar benéfica a atenção mais próxima que tem sido dada às turmas do Parfor Presencial da pedagogia em termos de repercussão da qualidade da sua formação. No entanto, essa prática foi destacada por apenas alguns dos entrevistados. Com isso, práticas como as de planejamento da oferta das disciplinas, acompanhamento e orientação sobre a atuação metodológica do professor na condução das turmas, bem como a atenção e acompanhamento mais próximo ao aluno, foram observadas apenas em uma pequena parcela dos cursos sob chancela do Parfor.

No que se referiu à qualidade do corpo docente do curso de pedagogia ofertado para alunos atendidos pelo Parfor, observou-se movimento divergente entre os cursos. Nesse aspecto, foram valorizadas tanto a participação dos professores responsáveis pelas turmas do curso regular quanto a seleção e contratação de docentes fora dos quadros da universidade para suprir a demanda por oferta de vagas dentro do Parfor. No caso da contratação de professores, aspectos relativos a sua titulação e à avaliação posteriormente feita pelos alunos foram destacados como indicativos de qualidade. Já no caso de professores do quadro, a sua qualidade foi evidenciada por ter participado do processo de seleção da própria universidade, fazendo parte do seu corpo docente permanente. Em ambos os casos, não ficou muito clara a participação e envolvimento dos docentes em torno do projeto pedagógico do curso como indicativo de qualidade. Além disso, apesar da contratação de professores fora dos quadros das IES para atender às turmas de alunos do Parfor ter sido mais comum entre aquelas instituições com maior número desses alunos, tal procedimento também foi observado nas 
IES com poucos alunos do programa, obedecendo aparentemente a uma necessidade interna de ajuste, do que se configurando, efetivamente, como uma decisão em prol da qualidade da formação dos alunos-professores.

Por fim, destacou-se que aspectos relativos à infraestrutura como indicador de qualidade foram expressos apenas por um dos coordenadores entrevistados. Nesse caso, a biblioteca e os equipamentos de auxílio didático foram citados com aspectos importantes para a formação do discente. Porém, para a maior parte dos coordenadores, aspectos de infraestrutura do curso não mereceram comentários como indicadores de qualidade. A primeira questão do roteiro de entrevista oportunizou aos coordenadores identificarem a partir de sua própria perspectiva os aspectos gerais de qualidade do seu curso. Como resposta a esse questionamento, a maioria reconheceu como indicadores de qualidade aqueles voltados à organização didático-pedagógica e do corpo docente.

Assim, considerando os sentidos de qualidade evidenciados pelos indicadores e parâmetros utilizados pelo Parfor para a sua oferta de curso, além daquele já analisado em relação ao Sinaes, foi possível identificar, no capítulo que se segue, a relação estabelecida entre eles. Para tanto, essa relação foi contextualizada no quadro dos embates, ações e omissões que se articularam em torno dela, delineando o padrão que vem orientando (de fato) a qualidade dos cursos de pedagogia brasileiros. 



\section{QUALIDADE NA FORMAÇÃO DE PROFESSORES: DA PROPOSTA DE UM SISTEMA À REALIDADE DE UMA POLÍTICA}

Neste último capítulo, discutiu-se empiricamente a Política de Qualidade, emergida de forma subjacente às ações do Parfor, na oferta, e do Sinaes na avaliação de cursos de pedagogia. Para tanto, analisou-se, primeiramente, o processo de elaboração e desenvolvimento da política de formação docente, a partir da qual se derivou a questão da qualidade da formação do professor da educação infantil e dos anos iniciais do ensino fundamental (pedagogo). No contexto das discussões ocorridas no plenário do CTC-EB, foi possível evidenciar embates de interesses entre os órgãos internos do MEC, assim como entre a União, estados e municípios, os quais promoveram ações, não ações e omissões que configuraram a política em foco. Por fim, destacaram-se os critérios de qualidade assumidos na oferta de licenciaturas presenciais em pedagogia pelo Parfor e aqueles utilizados pelo Sinaes para avaliar esse tipo de curso, que estabeleceram, no seu conjunto, o padrão de qualidade sinalizado pelo governo para orientar a formação dos professores em questão.

\subsection{EMBATES, (NÃO)AÇÕES E OMISSÕES QUE CONFIGURARAM A POLÍTICA DE QUALIDADE}

A análise das atas de reuniões do CTC-EB permitiu destacar esse fórum como lócus dos principais embates que concorreram para a emergência da Política de Qualidade por meio da relação entre os critérios de qualidade utilizados pelo Parfor e pelo Sinaes nas suas ações em torno da pedagogia. Visando contextualizar tais embates, optou-se por discuti-los a partir de três fases distintas de atuação do Conselho. A primeira - de definição e implantação da política de formação de professores - compreendeu nove reuniões realizadas entre a instalação do CTC-EB, em fevereiro de 2008, até maio de 2009. Essa fase caracterizou-se pelas discussões em torno do sistema de nacional de formação docente, culminando na aprovação da atual Política Nacional de Formação de Profissionais do Magistério da Educação Básica.

A segunda fase - de busca da identidade - compreendeu oito reuniões realizadas entre junho de 2009 e dezembro de 2010, quando finalizou os mandatos dos primeiros conselheiros. Nas atas relativas a essas reuniões, foram registrados os desdobramentos da política de formação na organização do CTC-EB e ao papel a ser exercido pelo Conselho como órgão técnico-consultivo da Capes. E, finalmente, a terceira fase, iniciada após a renovação do CTCEB em novembro de 2011 e indo até a última ata analisada, referente a abril de 2013 
(totalizando oito documentos). Essa última fase foi marcada pelo arrefecimento nas proposições de institucionalização do Conselho, caracterizando-se pela falta de sequência às discussões ou encaminhamentos específicos sobre a formação docente.

Em relação à primeira fase, a instalação do CTC-EB na Capes marcou o início de proposições visando à elaboração de ordenamento legal para amparar as ações do Ministério da Educação voltadas à formação de professores da educação básica. Naquele momento, conforme trecho presente na Ata 1, havia uma expectativa de que "[...] o Conselho TécnicoCientífico da Educação Básica [pudesse] emanar o Sistema Nacional de Formação Docente e, a partir do que existe e está sendo oferecido, indicar um novo caminho a ser seguido.”

Como já referenciado no capítulo 1 , tal expectativa foi criada em função da Lei $n .^{\circ}$ 11.502, de 11 de julho de 2007, que agregou a formação de docentes da educação básica como nova competência da Capes (BRASIL, 2007a), deslanchando a criação de programas na Agência para atender a essa missão. Nesse sentido, a institucionalização do CTC-EB ocorreu em um contexto de expansão das iniciativas da Capes, notadamente aquelas voltadas à ampliação da oferta de licenciaturas para o contingente de professores sem a diplomação mínima exigida pela LDB. ${ }^{65}$ A ideia era estruturar um sistema nacional de formação de professores da educação básica, entendido como o caminho para integração das ações do MEC nesse campo. Tal sistema abrangeria, então, a oferta dos cursos e programas existentes e outros a serem ofertados, de forma a potencializar seus resultados e eliminar esforços em duplicidade.

As pretensões sistêmicas, inclusive, não se restringiam à formação docente. Essas eram tidas como ponto de partida para a integração das ações do Ministério de uma forma geral, uma vez que afetariam a qualidade da educação como um todo. Tal perspectiva assumia como pressuposto que a oferta de cursos de formação docente geraria impacto potencial, desde o Sinaes, na avaliação da qualidade dos cursos de licenciatura, e indo até o Ideb, como termômetro da repercussão da formação inicial e continuada na qualidade da educação básica, conforme indicou o registro da fala do então Ministro da Educação:

[Cabe ao CTC-EB] refletir sobre as diretrizes das licenciaturas e sobre a possibilidade de uma forma de 'alinhamento' ou uma combinação virtuosa de algumas ações do MEC, que hoje estão absolutamente fragmentadas. [...] A Capes fomentará a ampliação das licenciaturas e [de] programas, já estruturados, de formação continuada presencial e a distância do sistema público. [A] isso se chamará Sistema Nacional de Formação. [...] À Capes caberá organizar o fomento

\footnotetext{
$65 \mathrm{Na}$ Tabela 3, disponível na seção 1.1 do capítulo 1 desta tese, pode-se observar com mais detalhes o contingente de quase 600 mil professores que em 2009 não possuíam a qualificação exigida para o exercício da docência.
} 
para atingir a expectativa de aumentar o contingente do professorado, em especial, formado nas universidades públicas. [...] A construção do Sistema Nacional de Educação [começa] com o Sistema Nacional de Formação. [O Ministro] destacou o valor do Sinaes e a reconstrução do Saeb [Sistema de Avaliação da Educação Básica]. [Defendeu] o Ideb, como parte da construção do Sistema Nacional de Educação, que permite que a União apoie as redes mais fragilizadas, equalizando oportunidades (ATA 2).

Porém, tal proposta sistêmica de organização das ações de formação docente no âmbito federal repercutiu colateralmente na necessidade de discutir também as competências compartilhadas pelos entes federados, assim como a relação público-privada, em torno da qualidade e quantidade da oferta dos cursos de licenciatura e de programas de formação continuada. Além disso, a ideia de uma visão sistêmica do processo formativo de professores da educação básica terminou promovendo, ainda, a necessidade de uma reflexão mais ampla sobre as competências partilhadas entre órgãos do próprio Ministério, tendo em vista que estava sob a responsabilidade do CNE a deliberação sobre a organização das licenciaturas, impactando qualquer tipo de ação da Capes voltadas ao seu acompanhamento, mesmo que sob o ponto de vista apenas do fomento (resultados apresentados pelos cursos que receberam recursos públicos, por meio da Capes, para a qualificação de docentes). Tais impactos se materializavam não só no processo de organização acadêmica dos cursos integrantes do plano formativo, como também no próprio processo de gestão de sua qualidade, na medida em que possíveis ações avaliativas da Capes concorreriam com as do Sinaes. Assim, tal perspectiva sistêmica implicaria a necessidade de uma sintonia não só entre as competências de estados, municípios e a União, mas também no equacionamento das disputas entre IES públicas e privadas, bem como em mais diálogo da Capes com o CNE e com o próprio Inep.

Nesse contexto, um conselheiro do CTC-EB comentou, nos termos transcritos registrados nas Atas 2 e 3, que [...]

[...] o sucesso da Capes da pós-graduação [advém] de uma ação consciente, decidida e decisiva do Estado Federal com o apoio da comunidade científica. [Porém,] a Capes da educação básica vai trabalhar com quem ainda não se profissionalizou. [Lembrou ainda que] a ação da Capes agora vai incidir não só na área federal, mas também na estadual, municipal, o que exige adesão e consentimento. Para ele, o Conselho Nacional de Educação e o Sinaes podem se tornar parceiros, ou não. [...] [Alertou sobre] dois constrangimentos que complicam a elaboração do Sistema Nacional de Formação: [...] o CNE, [...] órgão que não é consultivo, é normativo, e [...] os atores que formarão o edital do Sistema Nacional de Formação, pois há a escola, a instituição formadora, a secretaria, estadual e municipal e a universidade [...] (ATA 2).

[sintetizou, então] dois pontos que foram revelados nas apresentações e intervenções que, se não forem enfrentados, limitarão o sistema nacional de formação de profissionais da educação que está sendo pensado: de um lado a relação públicoprivada, $80 \%$ da formação docente está nas mãos do sistema privado, e de outro a 
dimensão federativa, a capacidade de interferência direta da União no âmbito da formação docente que hoje é limitada (ATA 3).

Tendo como pano de fundo os pontos em debate - competência federativa; relação público x privado; e articulação das ações do MEC -, o CTC-EB criou um grupo de trabalho para dar respostas ao problema da carência de formação dos professores da educação básica. Como resultado, foi gerado um primeiro documento, posteriormente discutido por todos os conselheiros, contendo um esboço da base legal, regras de funcionamento, acompanhamento, avaliação e regulação das licenciaturas e demais programas que configurariam o sistema nacional de formação de professores. Esse documento procurou dar respostas aos grupos de interesse que se articulavam sobre o tema, seguindo a dinâmica proposta por Lowi (1972).

Alguns insumos para o grupo de trabalho e para as discussões que se seguiram foram discutidos no plenário do CTC-EB, tais como aqueles que estruturaram o acordo federativo em torno de ações do PAR, bem como dos Arranjos Educativos Estaduais, que mais tarde passaram a ser chamados de Fóruns Estaduais Permanentes de Apoio à Formação Docente. Além desses, interessou ao objeto estudado nesta tese destacar a apresentação sobre a regulação dos cursos de pedagogia feita pela então Coordenação-Geral de Apoio à Formação e Capacitação Docente da Educação Básica (CGDOC/DEB/Capes), visando esclarecer o Conselho sobre o tema. Em uma síntese da apresentação, foram registradas as seguintes conclusões:

a) A supervisão dos cursos de Pedagogia e Normal Superior deve ser analisada à luz da política da avaliação da graduação; b) Que se defina uma política de formação dos professores, construindo as bases para o Sistema Nacional de Formação; c) Necessidade de abrir o processo de elaboração do ENADE à comissão da Pedagogia e às entidades da área. d) Que o tempo de duração do curso de Pedagogia seja de quatro anos; e) Fortalecimento das CPAs - Comissão Própria de Avaliação nas IES. Acrescentou que a avaliação está no Inep e a regulação e a autorização na Sesu. Está disperso. Por isso, a ideia do Sistema que o Ministério está pautando é fundamental e urgente. [...] Ao fim da apresentação, foi mais uma vez aberta a palavra e [um] conselheiro [...] observou que no estatuto [dos cursos a serem ofertados pelo sistema em discussão] deve constar a vocação de formar professores (ATA 2).

Como se observou, a DEB/Capes levou ao CTC-EB preocupações sobre os resultados gerados pelo Sinaes para fazer a regulação da licenciatura em pedagogia, bem como a possibilidade de que essa licenciatura pudesse desviar-se da sua função de formar professores. 
Nessas preocupações, destacaram-se, ainda, referências feitas ao curso normal superior, ${ }^{66} \mathrm{em}$ paralelo ao curso de pedagogia, como possibilidade de formação de docentes da educação infantil e anos iniciais do ensino fundamental, a despeito da limitação legal a tais cursos impostas pelas Diretrizes da pedagogia.

A discussão desse tema pelo CTC-EB era justificada em função dos incisos IV e V do art. 14 do Estatuto da Capes vigente à época, que estabeleciam entre as competências do Conselho "acompanhar a avaliação dos cursos de pedagogia, licenciatura e normal superior nos processos de avaliação conduzidos pelo Inep", além de se manifestar nos seus atos regulatórios. Complementarmente, tal discussão pôde ser também justificada pela perspectiva da permeabilidade, discutida por Marques (1999). Naquele momento, a equipe da Diretoria de Educação Básica da Capes tinha entre seus integrantes alguns dos responsáveis pela implantação do Sinaes, saídos do Inep um pouco antes da adoção dos indicadores de qualidade instituído pela Portaria 40/2007, que detalhou o "decreto ponte" (BRASIL, 2007d). Nesse sentido, considerou-se que entre as motivações para tal apresentação estivesse presente não só uma necessidade de cumprimento de uma competência estatutária, mas também uma visão crítica do trabalho que vinha sendo realizado pelo sistema avaliativo, notadamente no âmbito das licenciaturas foco do trabalho na Capes.

Do ponto de vista acadêmico, a discussão sobre a regulação dos cursos de pedagogia pôde ser inserida, ainda, no contexto dos resultados apresentados pela pesquisa de Gatti (2009) sobre a pouca ênfase dos conteúdos afetos à docência presentes nos currículos desses cursos. Além disso, como já mencionado, os resultados da pesquisa de Souza (2013) indicaram mais recentemente pouca ênfase dos conteúdos diretamente afetos à docência nas questões do Enade, reforçando a pertinência das preocupações então levantadas sobre a regulação da qualidade dos cursos de formação docente baseada no Sinaes.

Em síntese, havia certo questionamento do CTC-EB sobre a capacidade do Sinaes em oferecer respostas para a regulação adequada da qualidade dos cursos de pedagogia. Esse curso, criado no Brasil na década de 1930 para atender à necessidade de especialistas em educação (bacharel), teve o perfil do seu egresso redimensionado pela base docente, a qual alicerçou suas diretrizes curriculares. Talvez por isso, houvesse uma percepção no Conselho

\footnotetext{
${ }^{66}$ Segundo definição do MEC, disponível na home page http://sejaumprofessor.mec.gov.br, o curso normal superior é definido como "um curso de graduação, na modalidade licenciatura. Tem por finalidade formar professores aptos a lecionar na educação infantil e nos primeiros anos do ensino fundamental". Na mesma página, o MEC informa que a licenciatura em pedagogia tem a mesma função do curso superior. Destaca, porém, que os "cursos de pedagogia também formam profissionais para atuarem na gestão do sistema escolar, mas a prioridade é a formação de professores".
} 
de "falta de vocação do curso [de pedagogia] para formar educadores", conforme registrado na Ata 2, justificando a pertinência dessa discussão e as preocupações levantadas.

Infelizmente, a dinâmica estabelecida pelas pautas de reuniões do CTC-EB não favoreceu o aprofundamento sobre tal percepção, tampouco sobre sua relação com as diretrizes curriculares dos cursos de pedagogia ou nos critérios de qualidade do Sinaes, como se visualizou inicialmente nesta pesquisa. O debate no CTC-EB foi mais centrado nos desdobramentos políticos em torno da ideia de um sistema de formação docente do que, propriamente, na discussão teórico-acadêmica sobre a organização dos cursos a serem ofertados ou sobre o acompanhamento da sua qualidade.

Reconheceu-se, no entanto, que no documento-síntese apenso à Ata 4 - contendo as ideias iniciais do CTC-EB para sistema nacional de formação docente - houve uma preocupação com a questão da qualidade das ações de formação, no sentido de [...]

[...] superar a tradicional fragmentação das responsabilidades e ações do setor público na área, buscando garantir uma educação de qualidade para todos [...] e desenvolver propostas e instrumentos de incentivo, acompanhamento e avaliação que promovam a integração e a qualidade das ações de formação inicial e continuada de professores em nível superior, [implicando] definir princípios e fundamentos que sustentem a elaboração de diretrizes para a qualificação dos professores e o direito à formação integral com qualidade (ATA 4, Anexo I, p.7).

Dessa forma, foi possível considerar que mesmo não tendo sido encontradas, nas atas, ações concretas do CTC-EB para garantir a efetiva qualidade da oferta de formação, originalmente, houve uma preocupação de que os programas e cursos fomentados pela Capes fossem acompanhados pelo Conselho. Nesse momento inicial, havia, inclusive, uma crítica velada à capacidade do Sinaes de garantir essa qualidade, uma vez que foi expresso o entendimento de que o crescimento da oferta de cursos por IES privadas ocorria "sem o devido acompanhamento e controle de qualidade, [exigindo] uma atuação mais consistente e abrangente por parte do governo federal, em especial junto aos cursos de formação de professores ali ministrados" (ATA 4, p. 8).

Nesse sentido, a despeito de as diretrizes acadêmicas de orientação, organização e avaliação dos cursos nunca terem sido discutidas ou implementadas pelo CTC-EB, as ideias em torno da necessidade de se discutir a questão da qualidade dos cursos fomentados pela Capes estiveram presentes nos encontros do Conselho. Tanto assim que na minuta de documento legal apensa à Ata 5, o CTC-EB trouxe a qualidade como eixo estruturante da perspectiva sistêmica proposta, de forma que o sistema nacional de formação permitisse 
planejar, ampliar e qualificar sua oferta. Por fim, coroando a concepção do sistema de formação de professores, a minuta definiu expressamente no seu art. 11 (ATA 5, p. 11) que o MEC deveria assegurar coerência entre os cursos ofertados e os processos de avaliação da educação básica e superior com os demais programas do Ministério, com os currículos mínimos da educação básica e com as diretrizes curriculares nacionais dos cursos de licenciatura, levando a uma articulação desejável entre essas ações.

Porém, não houve detalhamento sobre a execução prática de competência tão complexa, subentendendo-se que caberia à Capes a proeminência na condução do sistema em gestação. Esse ponto talvez tenha sido uma inobservância basilar àquilo que Scokpol (2002) chamou de insulamento da burocracia, ou numa tradução livre, nos interesses da burocracia em si, não necessariamente vinculados aos interesses da sociedade civil. A falta de definição sobre a condução desse processo de articulação de ações voltadas à formação de professores entre órgãos do MEC, aparentemente, gerou dúvidas acerca da reorganização das competências institucionais em questão. Não estava descartado o risco de que alguns dos órgãos envolvidos pudessem ser extintos ou esvaziados, fazendo como que o insulamento burocrático se evidenciasse nos interesses específicos desses agentes públicos. Diante desse quadro, ambiguamente, o delineamento da proposta do Sistema Nacional de Formação pareceu ser o início da sua dissolução pelo tencionamento das competências do CTC$\mathrm{EB} /$ Capes em relação às competências do $\mathrm{CNE}$, da Conaes e do próprio Inep, sem que os limites e diferenças tivessem sido devidamente esclarecidos.

Além da questão da divisão interna de competências dentro do MEC, houve ainda a disputa por outros pontos levantados pela proposta de sistema, contida na minuta do documento legal disponibilizado para debate público, a saber: a) a dualidade público-privada na oferta com qualidade dos cursos, que colocou de um lado a preferência da maioria dos membros do CTC-EB pela oferta pública dos cursos e programas e, do outro, a posição da direção da Capes de garantir ambas as ofertas, utilizando-se do argumento de que, independentemente da natureza jurídica das IES, projetos de boa qualidade deveriam ser identificados e fomentados pelos recursos disponíveis para o sistema; b) a questão da modalidade do ensino (presencial ou a distância), na qual se estabeleceu uma tendência no Conselho em prol da prioridade da formação inicial de forma presencial; c) a questão federativa, destacando-se a relação entre estados, municípios e a União em meio à proposta de participação voluntária e colaboração entre eles e a proeminência do MEC na coordenação das ações do sistema e no suprimento de suas deficiências, a fim de evitar a dispersão de esforços (ATA 4, ANEXO I). 
A contribuição de diversos atores ligados a entidades de classe, representações acadêmicas e profissionais voltadas à educação foi intensa ${ }^{67}$ e permitiu visualizar essa política pública em formação dentro da perspectiva trazida por Souza (2006), uma vez que favoreceu os embates em torno de preferências, interesses e ideias dos diversos grupos afetados por ela. Em síntese, tais embates puderam ser assim agrupados: i) questões político-partidárias, emergidas das competências dos entes federados e seus dirigentes locais; ii) interesses dos grupos, notadamente das IES; e iii) interesses dos burocratas, nas figuras do MEC, Capes, CNE e Inep.

Segundo Faria (2003), tal configuração de interesses pode ser denominado "triângulo de ferro" - burocratas, políticos e demais grupos de interesse - que tradicionalmente influencia e termina por formatar as políticas públicas. Além disso, de acordo com o autor, mais recentemente tem sido observada a crescente importância dos especialistas na formatação de políticas públicas, em função do conhecimento técnico para a formatação das soluções para o problema a ser resolvido. No entanto, os dados apontam que o CTC-EB, não obstante o seu caráter técnico-científico, ficou fragilizado como grupo de interesse específico em torno das discussões que estavam sendo travadas: a incipiente organização da Capes nas ações voltadas à formação de professores da educação básica, bem como a inexistência de uma rotina prévia de atuação do conselho nessas atividades, pareceu ter limitado a sua atuação como um grupo de interesses específico.

Adicionalmente, a proposta do sistema de formação, estabelecida na minuta, implicaria mexer com as bases da compartimentalização das ações do MEC em prol da formação docente entre seus órgãos vinculados: Capes, CNE e Inep. Talvez, em função disso, tenha ocorrido certa mobilização interna para frear a proposta original, conforme expressou o registro da presença do presidente do CNE, na plenária do CTC-EB, para apresentar diversos esclarecimentos, bem como "desaconse[lhar] a possível atribuição ao CTC-EB de homologar cursos superiores, que burocratizar[ia] o colegiado" (ATA 6, p. 3). Se implementada, tal competência concorreria com as atribuições do próprio CNE e implicaria a adoção de um sistema avaliativo paralelo ao do Sinaes, específico para as licenciaturas.

\footnotetext{
${ }^{67}$ Segundo informação constante na Ata 6, a síntese com as sugestões contabilizou mais de cem páginas, vindas das mais diferentes entidades, tais como: CNE, Associação Brasileira de Tecnologia Educacional (ABT), Centro de Desenvolvimento e Educação Superior (Cedes), Consórcio das Universidades Comunitárias Gaúchas (Comung), Anfope, Associação Brasileira de Universidades Comunitárias (Abruc), Fórum Nacional dos Pró-Reitores de Graduação (Forgrad). Das 154 contribuições recebidas, 18 foram de instituições de educação superior, 17 de entidades sindicais ou acadêmicas, 9 de Secretarias e Conselhos e 110 de pessoas físicas das mais diferentes procedências.
} 
No seu conjunto, os embates, tanto internos quanto externos, conseguiram abalar o próprio arranjo pensado para o sistema nacional de formação, conforme sintetizado no registro presente na Ata 6:

[...] o Conselho Estadual de [Educação] de São Paulo - CEESP, em sua contribuição, apesar de não ter tido a gentileza de reconhecer a magnanimidade e abertura ao se colocar um Decreto na Internet para ser debatido, levantou, com pertinência, a questão do sistema nacional face ao regime federativo. Para prevenir e evitar questionamentos judiciais sobre a constitucionalidade, ou até ilegalidade, já sinalizados claramente pelo CEESP de que entraria no [Supremo Tribunal Federal] o assunto teria que ser analisado. [...] $\mathrm{O}$ decreto tratava de várias funções, algumas vezes no mesmo dispositivo, o que dava margem a leituras equivocadas. Organizar o sistema federal, tratar da função de fomento no âmbito federal era próprio de um decreto federal e isso estava na forma adequada. Também tratava da adesão dos entes federativos que era facultativa. Nesse sentido a função do decreto seria meramente orientadora. Talvez fosse o caso de se pensar na adesão dos Estados e Municípios alternativamente. [...] Estado era o detentor do monopólio do certificado, assim, a escola privada participava como uma rede privada no interior do sistema público; o sistema organizava a educação nacional e, no caso, tratava-se de um sistema federativo e aí estava o problema do conflito de competências e atribuições. Então era crucial definir os limites; políticas, normalmente são ancoradas em leis e os decretos visam justamente regulamentar alguma coisa que já está garantida na Lei; programas são programas de Governo que podem ou não terminar com ele. [...] a expressão 'nacional' não era imprescindível, pois visava apenas definir a sua dimensão territorial.

Nesse sentido, a proposta de criação de um sistema nacional de formação docente evidenciou disputas entre estados, municípios e União em torno do protagonismo do MEC e seu potencial de interferência na competência e autonomia locais, bem como disputas entre IES públicas e privadas em torno de recursos para a oferta de formação aos professores da educação básica. Adicionalmente, existia ainda um embate implícito entre órgãos do próprio MEC sobre o papel da Capes na condução de um sistema que envolveria todos. Como consequência, apesar de o desejo de criação de um sistema nacional de formação docente estar presente originalmente tanto no discurso dos dirigentes quanto nos documentos e discussões do CTC-EB, as divergências entre os interesses decorrentes da proposta se materializaram como entraves à urgência do MEC em dar respostas ao problema da formação de professores por meio da organização da alocação de recursos, provocando a seguinte posição do Ministro:

[...] até que fosse tomada uma decisão, as reuniões [do CTC-EB] teriam que acontecer quantas [vezes] fossem necessárias, porque o conjunto de contribuições era expressivo e valia a pena se deter em cada uma delas. Contudo, como aconteceu em outros programas estruturais do MEC, que geraram repercussões as mais variadas, não seria diferente com o sistema de formação. Considerou que os constrangimentos de ordem material, de ordem legal, muitas vezes inibiam um 
avanço maior. Para não desperdiçar recursos públicos o que precisavam fazer, e era incontornável fazer, era disciplinar a política de fomento da CAPES em relação à formação inicial e continuada. O orçamento da CAPES triplicou e metade dele, dos 2 bilhões, se destinava à formação de professores. Assim, era preciso ter regras para a utilização desses recursos, teria que ter critérios, fosse ou não editado [o sistema].

A perspectiva de recuo à proposta do sistema federal desenhado provocou reações no CTC-EB, notadamente dos conselheiros que defendiam um protagonismo na atuação da Capes no desenvolvimento do sistema em discussão, conforme fragmento presente na Ata 6, a saber:

O Diretor [...] expressou a sua frustração de pensar que estariam trabalhando em algo menor que Sistema e sua dificuldade de assimilar isso por várias razões, entre elas a atribuição dada ao Conselho pelo Decreto que criou a 'nova' CAPES: "contribuir para a construção do sistema nacional de formação de professores" e todo o trabalho que vinha sendo feito nessa direção; A ideia de Sistema veio de uma percepção das dificuldades educacionais do país: falta de formação inicial, valorização para educação continuada dos professores, péssima qualidade, necessidade de formar professores habilitados. [...] Então, não se podia chamar esse sistema unicamente de público, porque nessas questões o público não separava do privado. O nacional, sem imposição, sendo por adesão, uniria. [...] Além da expectativa das entidades, das instituições e das pessoas que mandaram contribuições que seria malograda, o preocupava correr o risco de recomeçar a discussão e chegar a julho sem concluir. Já que havia a clareza das grandes questões, fez um apelo para que fizessem um esforço concentrado nos próximos dias, acertando as diferenças sobre alguns dos temas centrais, de forma a viabilizar o Decreto, imediatamente, como Sistema Nacional. [...] A posição da conselheira [F. N.] foi de que [...] Apesar de haver o compromisso de criarem o Sistema, não dava para cumpri-lo em 10 dias, sem maturidade. Construiriam, com calma, a agenda com o CNE e com as entidades. Já o Conselheiro [A. C.P. apontou que] a questão do sistema havia sido colocada e discutida longamente, desde a primeira reunião do CTC-EB e não deviam recuar nisso. [...] O representante da SEB [...] avaliou que pela natureza do Conselho, deveriam ter ao mesmo tempo clareza, serenidade e agilidade. Na sua percepção[...] falar de política nacional de formação de professores era muito distinto de falar de sistema nacional de formação de professores, assim como falar em sistema nacional ou falar apenas em sistema eram coisas distintas, mas não antagônicas. [...] Tinham que avançar nessa discussão, principalmente identificando quais seriam os pontos de consenso. [...]. A conselheira [M. M. C.], indignada, interrompeu a fala, para dizer que [...] haviam chegado a um encaminhamento bastante pragmático que respondia a busca de um consenso, de se resolver o problema da regulamentação das ações da CAPES e continuar a discussão do tema do sistema em colaboração com o Conselho Nacional, se surpreendia com as falas dele [representante da SEB] e do Diretor [...] que fechavam de novo as portas, trazendo-os de volta para um impasse. [...] Na visão da Conselheira [S. D.], haviam enveredado por um caminho que não era o melhor nem para eles, e nem para as pessoas que dependiam das decisões do Conselho. Declarou-se extremamente frustrada, foram todos convidados para fazer um Sistema e isso era um momento único, não sabia quando teriam outra oportunidade como essa [...] (ATA 6).

Aqui se observou claramente a divisão do CTC-EB em dois grupos posicionados contra e favor à aprovação do Sistema. No entanto, os mesmos registros que permitiram identificar esses grupos não evidenciaram os motivos que os fizeram seguir entre uma e outra afiliação, tampouco a correlação de forças que se estabeleceram. Foi possível constatar, 
apenas, que a presidência da Capes se manifestou pela urgência de uma decisão, fosse ela qual fosse, em prol de uma solução para a questão orçamentária da Agência, já expressada pelo Ministro. Em síntese, o dirigente máximo da Agência abriu mão de uma disputa em torno de competências institucionais com outros órgãos e defendeu a possibilidade de revisão e aperfeiçoamento da proposta do sistema de formação docente posteriormente.

Nesse contexto, os grupos internos ao MEC delinearam-se como o principal foco de resistência ao sistema que estava sendo proposto. Tal entendimento emergiu da posição trazida por Rocha (2005) sobre o peso da burocracia estatal na definição de políticas públicas, bem como dos dados empíricos, os quais indicaram: i) que a questão público x privado tinha sido encaminhada na proposta do Sistema; ii) que a questão federativa já tinha sido contemplada pela estrutura dos Fóruns Estaduais; e iii) que a proposta do sistema implicava, sobretudo, a proeminência da Capes para a garantia de qualidade dos cursos de formação docente. Dessa forma, nos pontos em que havia possibilidade de embates entre as competências do CTC-EB com o Inep ou com o CNE, ocorreu um recuo nos (re)arranjos organizativos em torno de sistema nacional de formação.

Primeiro, houve um redimensionamento das discussões em torno do papel reservado ao Conselho dentro da política de formação docente, o qual passou a ser apresentado como um aspecto separado da discussão que estava sendo travada para a organização legal e orçamentária do sistema de formação. Com isso, as pretensões de institucionalização do Conselho, como um corpo burocrático dentro da Capes, passaram a ser vistas como menos relevantes e poderiam ser tratadas posteriormente. Segundo, não se aprofundou a divisão de competência da Capes, como protagonista do sistema em formação, em sua interface com competências assumidas pelo Inep na condução do Sinaes, bem como na relação ainda muito confusa entre as competências do CNE e do CTC-EB na definição de diretrizes de organização de cursos de licenciatura. Terceiro, priorizou-se o argumento de urgência do MEC/Capes para a definição do decreto a ser sancionado, visando regular a atuação da Agência e a execução do seu orçamento reservado à formação docente da educação básica, independentemente de se ter, ou não, um sistema de formação docente.

Assim, a despeito dos argumentos a favor do sistema, os quais deslancharam os trabalhos do Conselho, venceu o entendimento "de que não falar em sistema e sim em política [de formação docente] não era um recuo do CTC-EB. [Podia ser visualizado como um] 'considerado' inicial que apontasse para o Sistema Nacional, [representando] um avanço e não de recuo" (ATA 7). Em consequência, perdeu força a definição de uma diretriz acadêmica 
de organização da oferta dos cursos, mecanismos internos de acompanhamento ou padrão de qualidade fora daqueles critérios estabelecidos isomorficamente pelo Sinaes.

Assim, a perspectiva sistêmica foi suprimida nas discussões que se seguiram, corroborando o entendimento de que as decisões que envolvem as relações entre o Estado e a sociedade civil são eminentemente políticas, mesmo quando revestidas de argumentos técnico-científicos. Em lugar do sistema nacional de formação de professores foi sugerida e aprovada a política de formação docente, organizada federativamente por meio dos Fóruns Estaduais e integrada por IES públicas e privadas sem fins lucrativos. No que se referiu à perspectiva de qualidade dos cursos ofertados, foco desta pesquisa, consolidou-se o entendimento de que "a graduação é avaliada pelo Inep" (ATA 25, p. 4). Aspectos específicos sobre cursos de licenciaturas não tiveram espaço para discussões ou novos encaminhamentos - como, por exemplo, as especificidades da formação de professores presentes nos cursos de pedagogia já levantadas, ou mesmo dúvidas sobre a efetividade do Sinaes no suporte à regulação da expansão, com qualidade, dos cursos de formação docente.

O Sinaes e seus parâmetros foram, então, apropriados acriticamente no âmbito da Política Nacional de Formação de Profissionais do Magistério da Educação Básica, Decreto n. ${ }^{\circ} 6.755,29$ de janeiro de 2009 , estabelecendo-se no seu art. $10 .^{\circ}, \S 2 .^{\circ}$, que os programas de formação inicial, apoiados com recursos da Capes, à revelia de qualquer critério específico que pudesse contemplar as IES estaduais e municipais, precisariam, apenas, ter avaliação positiva no Sinaes (BRASIL, 2009a).

No entanto, pôde-se reconhecer que, embora o sistema de formação de professores tenha cedido lugar para a política de formação docente, essa posição foi inicialmente aceita pelo CTC-EB dentro de uma visão de complementaridade. Entendia-se que tal política se constituiria num primeiro passo em busca do sistema articulado de formação inicialmente planejado, o qual poderia vir a ser estabelecido paulatinamente a partir da atuação do CTC-EB naquelas competências estatutárias que lhe cabia. Apesar desse entendimento, os desdobramentos das ações e, principalmente, das não ações do Conselho na condução da política de formação docente foram influenciados por embates entre órgãos do MEC que contribuíram para a emergência da Política de Qualidade, conforme definida nesta pesquisa.

A segunda fase de atuação do CTC-EB - de busca da sua identidade - foi particularmente marcada pela tentativa de resgate da concepção do sistema nacional como uma evolução natural da política de formação vigente, tendo como ponto de partida a busca da identidade do CTC-EB. Em julho de 2009, esse movimento foi retomado, conforme registro presente na Ata 9 de que [...] 
[...] no ano passado [2008] ficaram envolvidos com a criação de um sistema de formação e deixaram de lado a discussão sobre a regulação de quais são as tarefas do CTC. Desse ponto de vista, teriam mesmo de pautar, no nível interno, uma conversa sobre [...] a fragilidade atual do CTC[-EB] por problemas de agenda, da necessidade de estabelecer um calendário de reuniões, de se organizar, da falta de receber documentos que permitam acompanhar o que está sendo executado. Todos os conselheiros se sentiram contemplados com essa posição e passaram a tratar da agenda das próximas reuniões (ATA 9).

Para dar sequência à discussão sobre as tarefas do CTC-EB, houve um realinhamento do trabalho desenvolvido na sua primeira fase de atuação, contemplando três comitês, assim definidos: Comitê 1: Acompanhamento da Política Nacional de Formação de Profissionais do Magistério; Comitê 2: Desenhos Pedagógicos e Avaliação; Comitê 3: Programas e Políticas de Fomento. Numa primeira aproximação, tal disposição pareceu contemplar a essência de atuação do Conselho prevista no Estatuto da Capes. Assim o Colegiado, por um lado, acompanharia os desdobramentos da política e, por outro, tentaria resgatar suas competências estruturantes, ao discutir os desenhos pedagógicos dos cursos, sua avaliação e fomento.

No relato do trabalho desses comitês - ou câmaras como também são referidas nas atas - evidenciou-se o compromisso do Conselho com o aperfeiçoamento da política de formação, notadamente das ações abrangidas pelo Parfor, conforme pode ser observado no extrato constante da Ata 12, quando foi defendida pelo Comitê 1:

[...] há necessidade de participação do CTC-EB no acompanhamento e avaliação do processo de implantação dos fóruns estaduais permanentes, com vistas a conhecer e comparar os diversos formatos e encaminhamentos dados até o momento, com participação direta de dois membros junto à Capes, além de colaborar no processo de avaliação que está sob a responsabilidade da Capes e na construção de instrumentos e de formas específicas de diagnose. Foi observado um conjunto de itens considerados importantes de serem discutidos pelos membros do Conselho: qual o papel da Universidade do Estado na seleção dos professores que serão matriculados nos cursos ofertados, como será esse processo seletivo e a necessidade de validação de inscrições pelas secretarias de educação. Foram considerados pelo grupo: a forma de acesso e seleção dos professores para os cursos ofertados, e em decorrência, o papel da Plataforma Freire, considerado bastante positivo, mas com necessidade de alguma revisão, como, por exemplo, as falhas na emissão de relatórios que são fragmentados, assim como os critérios para a oferta de cursos, a qualidade da formação dos professores, a necessidade do plano de expansão e oferta de formação para professores em exercício e a negociação das metas e cursos com os estados. Considerou-se também que é preciso criar desenhos de cursos específicos, programas especiais para permitir a formação de professores em exercício, e para isso há necessidade de se definir critérios. Entre as conclusões, a necessidade de revisão da plataforma Freire, a garantia de discussão no plano das concepções dos cursos - o campo pedagógico e campo político, a formação continuada e a formação inicial recomendando-se a divisão do Fórum permanente por câmaras temáticas (ATA 12). 
Considerando esse posicionamento, diversos pontos relacionados à qualidade na oferta de cursos e ao trabalho estratégico da Capes foram assumidos como de competência do Conselho, dentre os quais se destacou a necessidade de definir critérios para os desenhos pedagógicos dos cursos ofertados, bem como sua concepção do ponto de vista da formação inicial e continuada. Porém, na prática, o trabalho de organização do CTC-EB por meio dos seus comitês se mostrou pouco efetivo. As pautas estabelecidas para suas reuniões não permitiram desdobramentos dos pontos levantados, tampouco permitiram avanços na sua discussão, muito menos em deliberação ou consulta. O produto do trabalho do CTC-EB nessa segunda fase se configurou, notadamente, em simples propostas de atuação, apesar de constantes iniciativas de diversos conselheiros em avançar na discussão das suas competências em prol de um sistema nacional de formação docente.

Talvez para compensar a falta de encaminhamento nas discussões elencadas pelos conselheiros, diversos assuntos foram levados ao CTC-EB. Porém, tais temas tinham caráter apenas informativo, sem que se tivesse qualquer tipo de consequência. Entre esses temas, destacam-se aqueles relativos à Rede Nacional de Formação Continuada dos profissionais da educação básica, a proposta criação da matriz de referência para o exame nacional de docentes (atual prova de seleção de docente para atuar nas redes públicas de educação básica), ou a criação de uma revista específica da educação básica na Capes, nos moldes da que vem sendo publicada para a pós-graduação. Até mesmo temas diretamente afetos à política de formação docente, tais como o Parfor, a UAB, o Programa Institucional de Bolsas de Iniciação à Docência (Pibid), o Pró-Docência, o Observatório da Educação, o edital do Programa Novos Talentos, o Pró-Letramento, o Programa Gestão da Aprendizagem Escolar (Gestar II) e o Pró-Infantil foram apresentados sem que qualquer gerência do Conselho tivesse sido registrada.

Além disso, em nenhuma das atas de reuniões classificadas como pertencentes à segunda fase de atuação do CTC-EB foram encontrados temas relativos à formação docente que tenham demandado deliberação do Conselho. Nem mesmo quando o assunto apresentado foi o Parfor houve desdobramentos em termos de sua avaliação, do seu desenho pedagógico ou de aspectos relativos ao seu fomento. Além disso, chamou a atenção que programas voltados à formação continuada fossem simplesmente apresentados aos Conselheiros sem que qualquer tipo de relatório ou parecer tivesse sido emitido pelos seus membros.

O caso específico do Programa de Mestrado Profissional em Matemática em Rede Nacional (Profmat) - que vem oferecendo pós-graduação stricto sensu a distância em matemática para professores das redes públicas de educação básica, por meio da UAB em 
parceria com a Sociedade Brasileira de Matemática (SBM), sintetizou o desconforto do Conselho em estar fora de decisões da Capes sobre ações voltadas à educação básica. Conforme registro da Ata 17:

[...] a conselheira [L.A.] propôs uma moção para mostrar o descontentamento do
Colegiado com a oferta do Profmat, que a seu ver, trata-se de um Mestrado
Profissional a distância. Houve uma discussão bastante acirrada sobre o assunto e o
Diretor [da Capes] explicou que a proposta era de 'uso de tecnologia de Educação a
Distância'. A conselheira [S.D.] informou que no site do SBM consta que o Profmat
é um programa de pós-graduação stricto sensu semipresencial. A conselheira [F.N.]
manifestou preocupação quanto à articulação dos dois Conselhos da Capes (CTC-
EB e CTC-ES) e a rápida forma como o Profmat foi aprovado e que o projeto
deveria passar pelo Conselho da Educação Básica. O Diretor concordou, porém
observou que as críticas apresentadas na moção de protesto são amplas, e que
deveria apenas constar a questão do projeto de formação continuada de professor da
rede pública. A conselheira [Z.P.] explicou que como está na CAPES, o curso
assume uma perspectiva de mestrado profissional, mas o curso destina-se à
formação continuada dos professores da rede pública. O curso é para rede
credenciada pelo MEC para oferta de curso na modalidade a distância (ATA 17).

Nas atas analisadas, foram recorrentes os destaques sobre a preocupação dos Conselheiros com a (falta de) atuação do CTC-EB na condução da política de formação, ao mesmo tempo que buscava estabelecer a sua identidade e função específica na Capes. Conforme se pôde observar, na Ata 15, “[...] o Conselheiro [R.L.] lembrou a importância de o Colegiado opinar sobre a programação anual da Capes na área específica de educação básica, o que nem sempre tem acontecido".

Esse registro, aliado a outros presentes nos dados analisados, reportava-se às competências legais atribuídas ao Conselho pelo Estatuto da Capes naquela época (BRASIL, 2007c), entre as quais se destacaram: i) o estabelecimento de parâmetros para avaliar os programas de fomento e os cursos que receberiam recursos financeiros da Agência (art. 14, inciso X); e ii) a manifestação do CTC-EB nos processos de reconhecimento e renovação de reconhecimento de cursos de formação de professores (art. 14, incisos V e VI) (BRASIL, 2007c). Nesse sentido, o colegiado precisaria definir critérios para avaliar o fomento de cursos e programas e, ao mesmo tempo, teria de se pronunciar sobre a regulação da licenciatura, levando-o a utilizar seus próprios critérios para balizar a avaliação realizada pelo Sinaes para manter sua coerência. Com isso, invariavelmente, terminaria por interferir na autonomia de órgãos do MEC diretamente envolvidos nesse processo.

Depreendeu-se, então, que em função da expectativa de atuação do CTC-EB em um sistema nacional de formação de professores, ainda hoje presente no Estatuto da Capes, as iniciativas de avaliação do colegiado terminavam por confundir-se com o estabelecimento dos 
próprios parâmetros de avaliação de cursos de graduação de uma forma geral, a cargo da Comissão Nacional de Avaliação da Educação Superior (Conaes) e que operacionalizam o Sinaes. Essa perspectiva de entendimento foi reforçada pela presença de representantes do Inep e da Secretaria de Regulação da Educação Superior do MEC (Seres) nas reuniões do CTC-EB para apresentar possíveis formas para que tal competência se concretizasse. No entanto, a proposta apresentada foi no sentido de submeter os critérios a serem estabelecidos pelo Conselho àquilo que já estava institucionalizado pelo Sinaes, sem muito espaço para instigar mudanças em seu status quo.

Como pôde ser observado no trecho contido na Ata 14, a proposta trazida pela Seres e pelo Inep igualava o CTC-EB a especialistas organizados em comunidades epistêmicas, no sentido definido por Haas (1992) - portanto, não pertencentes à burocracia estatal -, a partir de uma atuação [...]

[...] semelhante à $\mathrm{OAB}$ nos cursos de Direito e ao Conselho Federal de Biologia nos cursos de Biologia que dão pareceres após a avaliação feita pelo Inep. Não estão previstas manifestações nas autorizações, somente nos reconhecimentos e renovação de reconhecimento. Foi informado que essa é uma disposição que está já escrita à espera de um comando do Conselho para se tornar realidade (Ata 14)

Nesse sentido, embora o CTC-EB/Capes tivesse recuado na estruturação de um sistema de formação, as suas competências legais o impulsionavam em prol da construção desse sistema. Com isso, novamente, as competências do Colegiado estavam no centro dos embates internos da burocracia do MEC, sem que houvesse uma predisposição política para uma discussão mais ampla sobre a organização interna do Ministério em torno da formação docente e da regulação de sua qualidade.

Apesar de o Colegiado, por meio de alguns de seus membros, reforçar a questão da avaliação dos cursos de formação inicial e de programas de formação continuada e da criação de "uma cultura de licenciaturas e de pedagogias que tenham um nível de excelência reconhecido e que possam, positivamente, contaminar outras instituições que as ofereçam" (ATA 16), não havia espaço político para o CTC-EB realizar aquilo que lhe cabia: verificar a efetividade, as condições e os resultados dos cursos de formação dentro da política de formação docente. Dessa forma, a possibilidade de ações do Conselho em prol da definição de uma política de qualidade para a formação de professores foi substituída pela sua não ação, seguindo a dinâmica considerada por Souza (2006) e Muller e Surel (2002) sobre a institucionalização de políticas públicas. 
Os dados deixam entrever que o entendimento de dirigentes da Capes foi no sentido de que o estabelecimento de parâmetros para avaliação de licenciaturas fomentadas pela Agência poderia interferir na divisão de papéis avaliativos partilhados com o Inep, posição anteriormente já evitada. Nesse sentido, conforme ratificou trecho da Ata 16, transcrita a seguir, foi informado [...]

[...] que a Capes avalia pós-graduação, mas quem avalia a graduação é o Inep. Assim, a Capes não pode avaliar as licenciaturas, mas sim programas institucionais de formação [...] pensando nas exigências da [Controladoria Geral da União] CGU, a Capes decidiu contratar, pela Unesco, consultores para verificar se o caminho está correto. Essa ação da Diretoria de Educação Básica, chamada de acompanhamento, [... ocorrerá] no final de outubro e em novembro será elaborado um roteiro [...] os analistas serão divididos para visitar todas as instituições que estão oferecendo cursos pelo Parfor e verificar de que forma esses cursos estão sendo ministrados e quais as dificuldades. Informalmente já foram feitas algumas visitas (ATA 16).

Considerando os posicionamentos constantes desses fragmentos, entendeu-se que a perspectiva de separação de competência entre Capes e Inep levou a primeira a agir autofagicamente em relação ao seu CTC-EB, pois (i) o Conselho deixaria de estabelecer parâmetros avaliativos para balizar a concessão do fomento pela Capes aos cursos de formação inicial de docentes, assumindo o entendimento de que esses já estariam definidos pelo Decreto que instituiu a política de formação de professores, estando circunscritos ao Sinaes; (ii) a avaliação das ações de fomento da Capes - exigida pelos órgãos de controle e prevista no próprio Estatuto da Agência - seria realizada por um processo de acompanhamento realizado por consultores contratados sem vínculo empregatício com a Capes e sem qualquer supervisão do CTC-EB sobre sua atividade; e (iii) os parâmetros de avaliação dos programas de formação continuada - que por sua natureza não são avaliados pelo Sinaes - ficaram fora do contexto de discussão da qualidade no Parfor.

Com isso, entendeu-se que nessa segunda fase de trabalho do CTC-EB ocorreu um esvaziamento das suas funções. Os motivos para essa ocorrência puderam ser encontrados em duas vertentes. A primeira, derivada de análise do próprio Conselho de que ele não consolidou uma sistemática de trabalho "em parte porque também a própria Capes ainda está em fase de consolidação da sua atuação neste novo cenário de atribuições estabelecidas em Lei” (ANEXO I, ATA 17). A segunda, emergida dos dados analisados, de que o cuidado da Capes em não interferir nas ações avaliativas do Inep terminou por cercear a consolidação do Colegiado, levando a Política de Qualidade aqui discutida a se institucionalizar pela inércia do 
CTC-EB em torno da definição do padrão de qualidade dos cursos do Parfor, previsto como princípio pela política de formação docente (BRASIL, 2009a).

Essa falta de ação do Conselho foi comprovada pelo relatório por ele apresentado ao final do terceiro ano de mandato. Nesse relatório, o próprio CTC-EB refletiu sobre suas competências, então previstas nos treze incisos do art. 14 do Anexo I do antigo estatuto da Capes (BRASIL, 2007c), e aquelas efetivamente executadas, conforme documento anexo à Ata 17. Na avaliação do Conselho, apenas duas das treze competências previstas foram cumpridas: os incisos III e XIII, que tratavam, respectivamente, das diretrizes de longo prazo para a formação inicial e continuada e, portanto, refletiram-se na minuta do decreto que instituiu a política de formação e na representação do Colegiado no Conselho Superior da Capes. Nove das treze competências foram consideradas como pouco exploradas pelo CTC$\mathrm{EB}$, destacando-se aquelas referentes aos incisos I, IX e X, que tratavam respectivamente da instalação do sistema nacional de formação de professores, dos critérios e procedimentos para o fomento de pesquisa sobre a formação docente e dos parâmetros para a avaliação de cursos e programas dentro da política de formação. Com referência às duas competências restantes, justamente as que se reportam ao acompanhamento da avaliação conduzida pelo Inep para os cursos licenciatura (inciso V) e ao pronunciamento do conselho sobre a regulação desses cursos (inciso VI), o Colegiado entendeu em seu documento como competências "pouco discutidas".

Adicionalmente, embora conceitualmente as categorias "pouco discutidas" e "pouco exploradas" sejam muitos semelhantes, no contexto do CTC-EB elas se mostraram bastante apropriadas para resumir as ações do conselho em função das suas competências legais. Aparentemente, houve intenção em separar aquilo que chegou a ser discutido, mas foram pouco explorados de forma a se reverter em ações concretas daquilo que não foi discutido diretamente (pouco discutido). Seguindo esse entendimento, chamou a atenção que os pontos “pouco discutidos” se materializassem, de acordo com a classificação do CTC-EB, justamente naquelas competências que representavam áreas de contato entre as ações da Capes e as do Inep/Seres/Conaes/CNE em torno do Sinaes.

Ratificando o pressuposto da não ação como condicionante da emergência política de qualidade para a formação de professores, de forma geral, e da educação infantil e anos iniciais da educação básica, de forma específica, inexistiram registros sobre decisões do CTCEB em torno da qualidade dos cursos oferecidos pelo Parfor durante a terceira fase de trabalho do colegiado. Conforme destacado no início desta seção, do ponto de vista desta pesquisa, 
essa terceira fase de atuação do CTC-EB foi iniciada após o primeiro mandato, quando ocorreu a renovação dos seus membros.

Tal fase foi iniciada após um vácuo temporal no qual o CTC-EB foi tecnicamente desinstalado por quase sete meses, em razão da não nomeação de conselheiros. Em retrospectiva, o primeiro mandato dos seus membros, indicados em 8 de janeiro de 2008, foi prorrogado pela Portaria n. ${ }^{\circ}$, de 4 de janeiro de 2011, até 31 de março de 2011 (BRASIL, 2011c). Porém, apenas em 18/10/2011 os conselheiros escolhidos para essa terceira fase do CTC-EB foram efetivamente nomeados pela Portaria Capes n. ${ }^{\circ}$ 203, de 18 de outubro de 2011 (BRASIL, 2011d).

Adicionalmente, as alterações no Estatuto da Capes, por meio do Decreto n. ${ }^{\circ}$ 7.692, de 2 de março de 2012 (BRASIL, 2012), trouxeram entre outras novidades para o CTC-EB a supressão do incisos VI e X do artigo 14 do Estatuto anterior (BRASIL, 2007c). Com isso, deixou de ser competência do CTC-EB a manifestação em torno de atos de regulação de cursos de licenciatura, bem como a responsabilidade avaliativa sobre os cursos que recebem recursos financeiros da Capes, essa última anteriormente considerada pelo próprio colegiado como um dos eixos centrais da sua atuação (ATA 16).

Assim, ante a atrofia das atribuições do CTC-EB, bem como a descontinuidade na discussão sobre a divisão de competências entre os órgãos do MEC em torno da formação docente, as pretensões de institucionalização das atividades do Conselho foram abaladas. Tanto assim que essa terceira fase de atuação do Colegiado pôde ser caracterizada como um período de contemplação, no qual diversos temas foram discutidos, sem que fosse estabelecida uma linha de articulação entre eles, a saber: o currículo do ensino médio, o Programa Nacional de Acesso ao Ensino Técnico e Emprego (Pronatec), o programa Alfabetização na Idade Certa, o Programa de Intervenção Pedagógica (PIP) de Minas Gerais e a interação das áreas de educação básica com a de pós-graduação na Capes.

É preciso reconhecer, no entanto, que, nas primeiras reuniões do atual CTC-EB, houve a tentativa de resgate das discussões sobre suas competências estatutárias. Porém, no encaminhamento dado pela diretoria da Capes, a organização das três câmaras, originalmente propostas pelo antigo Conselho, apareceram com propósitos diferentes. Em vez de focalizar o acompanhamento da política de formação, sua avaliação e seu fomento, pretendeu-se que as câmaras assumissem como temas (i) Parfor, (ii) Universidade Aberta do Brasil (UAB) e (iii) Programas de Valorização do Magistério. Sem consenso, nem sobre a necessidade de câmaras, nem sobre os temas a serem abordados, foi decidido que em lugar dos comitês seriam "constituídos dois Grupos de Trabalho: um Grupo de Trabalho de Valorização do 
Professor e o Grupo de Trabalho de Acompanhamento dos Programas de Fomento em Andamento na Capes" (ATA 19). Posteriormente seriam encaminhadas para os conselheiros, então recém-nomeados, cópias das sugestões do antigo conselho. Porém, na reunião seguinte, não houve espaço programado na pauta para o relato do trabalho dos grupos, o qual só foi providenciado após solicitação dos conselheiros presentes. Mesmo tendo ocorrido as apresentações pelos dois grupos de trabalho, nenhum dos encaminhamentos apresentados por eles tiveram sequência nas reuniões seguintes.

Assim, no que concerniu ao padrão de qualidade dos cursos e programas fomentados pela Capes no âmbito do Parfor, os embates políticos ocorridos no CTC-EB, notadamente entre os órgãos do próprio MEC, limitaram sua discussão e definição. Como resultado, a qualidade dos cursos oferecidos pelo Parfor terminou modelada pelo uso acrítico dos resultados avaliativos do Sinaes (limitados ao Sistema Federal de Ensino Superior e ao isomorfismo do sistema avaliativo) pela desarticulação entre as ações de formação inicial e continuada, bem como pela inexistência de uma diretriz acadêmica na condução do Parfor.

Considerando esse quadro, foi preciso relembrar que a ampliação da missão institucional da Capes implicou manter suas tradicionais atividades de formação de pessoal avaliação e fomento da pós-graduação stricto sensu e pesquisa - com as novas, ligadas à formação de professores para a educação básica. Como discurso político, procurava-se alinhar essa nova atividade de formação ao "padrão Capes" de atuação, entendido como uma espécie de selo de garantia da qualidade dos cursos destinados aos professores da educação básica, fomentados por meio da Agência.

Entretanto, a nova missão institucional da Capes, aparentemente, concretizou-se por meio de atividades sobrepostas, sem a integração orgânica que se poderia esperar. Se, na ponta da pós-graduação e pesquisa, a avaliação costumou andar junto com o fomento, na ponta da educação básica, as ações que envolveram a avaliação dos cursos e programas fomentados não ficaram claras. Essa leitura pôde ser feita a partir do vigente estatuto da Agência (BRASIL, 2012) - que, no seu art. 2. ${ }^{\circ}$, parágrafos $1 .^{\circ}$ e $2 .^{\circ}$, separou o Conselho Técnico-Científico em educação básica e educação superior, lançando as bases das diferenças em sua atuação institucional. Enquanto o Conselho Técnico-Científico da educação superior (CTC-ES) é articulado às comissões de área de avaliação, as quais influenciam diretamente no trabalho desenvolvido das Diretorias de Avaliação, Relações Internacionais e de Programas e Bolsas no País, o CTC-EB é composto por representantes da sociedade civil ${ }^{68}$, sem atuação

68 Esses representantes caracterizam-se principalmente pela vinculação técnico-acadêmica com a área educacional. 
direta com trabalho das Diretorias de Formação de Professores da Educação Básica, de Educação a Distância, de Avaliação e de Relações Internacionais, membros natos deste último.

No âmbito das atividades relativas à educação superior na Capes, o papel das Comissões de Área de Avaliação ${ }^{69}$ caracterizou-se como central tanto nos processos de avaliação de programas e de cursos novos de pós-graduação stricto sensu quanto na seleção de bolsistas e projetos fomentados pela Agência. Ressaltou-se que, aparentemente, foram os embates, disputas internas e permeabilidade de ideias trazidas pelos especialistas que compõem as Comissões de Áreas que pareceram explicar a dinâmica de atuação da Capes em busca do alargamento das fronteiras do conhecimento científico e tecnológico, bem como revisão de sua atuação, procedimentos e critérios adotados na condução da Política de PósGraduação sempre que necessário. Por outro lado, no âmbito das atividades desenvolvidas em prol da política de formação de professores da educação básica não se observou semelhante papel reservado aos representantes da sociedade civil que participaram do CTC-EB. Além de não representarem necessariamente as licenciaturas, alguns membros pareceram não possuir vinculação acadêmica com elas. Nesse ponto, cabe enfatizar que se entende neste trabalho por áreas de conhecimento próprias das licenciaturas aquelas que discutem o ensinoaprendizagem em disciplinas voltadas aos alunos da educação básica, e não aquelas que discutem conteúdos afetos a bacharelados que têm interface de conhecimento com as licenciaturas, sem adentrar nas especificidades da docência.

Enquanto no CTC-ES se observou a representação de grupos vinculados a áreas de conhecimento que estão realizando a pós-graduação e a pesquisa no País (alunos, universidades e professores-pesquisadores), no CTC-EB inexistiu uma definição específica de ligação representativa entre os seus membros designados com os grupos envolvidos na reflexão e desenvolvimento dos programas de formação de pessoal para a educação básica. Todos eram apenas membros da sociedade civil, sem representação oficial e institucionalizada de qualquer grupo específico. Embora algumas associações de classes e acadêmicas estivessem presentes, a representação propriamente dita dos cursos e das IES não foi observada.

Nessa perspectiva, tal diferença de atuação pareceu se configurar no principal elemento de inflexão entre as novas e velhas ações da Capes, permitindo-se discutir a uniformidade de procedimentos entre as macroações da Agência. Enquanto na esfera da

\footnotetext{
${ }^{69}$ Conjunto de pesquisadores, organizados em áreas de avaliação da Capes sob a gerência de um coordenador de área de avaliação indicado pela comunidade acadêmica em lista tríplice e escolhido pela Capes.
} 
educação superior o papel dos especialistas mostrou-se institucionalizado, permitindo participação por meio de regras claras de representação e formas democráticas de escolha pela comunidade dos programas de pós-graduação que se submetem às ações da Capes, no caso das atividades vinculadas à educação básica não se encontrou organicidade de representação, nem de atuação da sociedade civil.

Enfatizou-se ainda que, historicamente, foi por meio do trabalho das comissões de avaliação que a Capes organizou a política de pós-graduação no Brasil, definindo critérios de qualidade, abrindo espaço para sua revisão e estabelecendo procedimentos para garanti-los. Dessa forma, pôde-se questionar até que ponto os assuntos da educação básica seguiram, na Agência, o mesmo padrão de condução definido para a avaliação e o fomento às atividades associadas à educação superior. Além disso, uma vez que a Capes não fez uso dos seus procedimentos tradicionais de atuação e ante a não ação do CTC-EB anteriormente apurada, não ficou claro quais instrumentos foram utilizados para conduzir a política de formação de profissionais do magistério da educação básica.

A recente intensificação na oferta de cursos de mestrados profissionais em rede para a formação de professores ${ }^{70}$ não pode ser considerada com uma resposta a esse questionamento. Tais cursos seguiram a lógica de avaliação e fomento da pós-graduação. Porém, mesmo considerando sua importância para o processo de formação continuada de docentes da educação básica, tais ações não pareceram se articular com os demais programas de formação continuada dentro do Parfor, nem foram capazes de responder sobre a condução da Agência em torno da qualidade da formação inicial.

Além disso, o novo Estatuto da Capes, reformulado em 2012, manteve no seu inciso V do art. 14 a competência do CTC-EB de acompanhar a avaliação dos cursos de formação inicial de professores, conduzidos pelo Inep (BRASIL, 2012). Porém, os dados presentes nas atas das reuniões do conselho analisadas nesta pesquisa indicaram que os pontos de contato entre as competências institucionais relativas a processos avaliativos conduzidos por Capes e Inep, no âmbito da política de formação de professores, têm proporcionado certa omissão nas ações avaliativas das agências irmãs: i) o Inep, por meio do Sinaes, não avançou em sua missão de implementar o Sistema Nacional de Avaliação da Educação Superior, abraçando de forma mais integrada a avaliação da pós-graduação; ii) a Capes não avançou na sua missão de orientar a política de formação de professores para a educação básica, evitando a adoção de

\footnotetext{
${ }^{70}$ A exemplo do ProfMat - área de matemática, também foram lançados o ProFís (física), ProfLetras (letras) em 2013, além do ProfArtes (Artes) e o ProfHistória (História) em 2014.
} 
critérios que, transpondo a perspectiva de isomorfismo do Sinaes, justificassem o fomento às licenciaturas abrangidas pelo Parfor.

A questão da divisão de tarefas da burocracia interna ao MEC sobre a qualidade dos cursos de formação docente voltados à educação básica mereceu, inclusive, sugestões de intervenções pelo CTC-EB no sentido de que [...]

[...] o MEC tenha uma 'Junta Educacional' ou um 'Conselho Articulador', similar à Junta Financeira, com objetivo de coordenar o trabalho integrado entre o CTC[-EB], Inep, CNE, Conaes, secretarias do MEC, no que se refere à avaliação e regulação dos cursos de Pedagogia e das outras licenciaturas no país (ATA 17).

No que se referiu à divisão de tarefas internas à Capes, o CTC-EB também pontuou que $[\ldots]$

[...] a divisão existente hoje [entre as diretorias da Capes para a] Formação de Professores - presencial e a distância - não faz sentido. Deveria ser Formação Inicial e Formação Continuada. A discussão que se faz necessária tendo em vista o paralelismo existente entre as duas modalidades nas universidades (ATA 17)

Nessa lógica, a atuação em separado das Diretorias de Educação a Distância e da Diretoria de Formação de Professores da Educação Básica poderia estar contribuindo pouco para o amadurecimento dessa política. No caso das atividades tradicionais de formação de pessoal de alto nível dentro da Agência, houve uma complementação no papel das diretorias entre avaliação, fomento/bolsa nacional e fomento/bolsa internacional. Já no caso das ações em prol da formação de professores da educação básica, o que se pôde observar foi a separação de atividades de uma mesma natureza: as duas diretorias executam tarefas parecidas, nas mesmas instituições, separando-se apenas as atividades entre presencial e a distância. Tal separação entre modalidades de ensino pareceu estar na contramão do que o MEC vem estabelecendo, quando suprimiu a Secretaria de Educação a Distância, bem como na utilização de instrumentos únicos para avaliação e regulação da educação superior, que independe da modalidade de ensino.

Adicionalmente, as diversas ações de formação inicial e continuada dentro da Capes e na sua relação com o MEC apareceram pulverizadas em diversos programas e editais, sem que o Parfor, no seu conjunto, fosse efetivamente gerenciado por alguma instância administrativa. Apesar da interface entre os diversos programas conduzidos pela Capes no contexto da Política Nacional de Formação de Profissionais do Magistério da Educação 
Básica, burocraticamente esses programas perpetuaram uma vida independente, sem a coesão interna esperada.

Assim, considerando essa análise, foi possível identificar quatro conjuntos de omissões subjacentes ao Parfor que sinalizaram pontos de interação dele com o Sinaes e com as DCN da licenciatura em pedagogia, reforçando a perspectiva de emergência de uma Política de Qualidade subjacente ao conjunto de suas ações. No seu conjunto, tais omissões terminaram por caracterizar a política evidenciada, contribuindo para reforçar os argumentos em torno de sua existência de fato, notadamente em função dos efeitos gerados por ela.

O primeiro conjunto de omissões contrastou as ações emergenciais de curto prazo, previstas no inciso III do art. 11 da política de formação docente (BRASIL, 2009a), com as de longo prazo, previstas nos incisos IV, VII e IX do art. 3. ${ }^{\circ}$ do mesmo documento legal. A prática das ações da Capes enfatizou a formação emergencial dos professores da educação básica (sentido presente), sem oferecer respostas claras sobre a formação de pessoal para atuar na educação básica (perspectiva de futuro). O Parfor, que envolveu parte das ações da UAB mais o Parfor Presencial e os cursos presenciais de formação continuada, ocupou-se prioritariamente das qualificações dos atuais docentes, no modelo atual de formação. Sobre os futuros docentes e à evolução dos cursos formadores, as ações foram pouco evidenciadas, conforme corroborou o CTC-EB ao destacar a "necessidade de debate pela Capes e pelos órgãos do Ministério da Educação de diretrizes políticas para a Formação de Professores, não centradas em ações emergenciais" (ATA 17).

Essa inconsistência entre a proposta de uma ampla política de formação de professores e a sua caracterização por ações de cunho emergencial, não pareceu gerar consequências imediatas num contexto em que existe demanda reprimida por formação inicial dos atuais professores. $^{71}$ Porém, no longo prazo, tal omissão poderá levar a possíveis prejuízos tendo em vista que: a) a burocracia, em sua disputa por orçamento e prestígio, pode adotar uma visão míope, transformando um programa emergencial em permanente; b) a desarticulação entre as ações de curto e longo prazo pode promover a perpetuação de programas pulverizados e a crescente duplicação de esforços; c) a inexistência de estratégias de longo prazo, voltada à formação dos docentes atuais e futuros, pode estagnar a perspectiva de inovação de uma política recém-nascida.

Um segundo conjunto de omissões que contribuiu para a caracterização da Política de Qualidade se referiu à localização da oferta pública de cursos como um padrão, a priori, de

71 Estatística discutida anteriormente na Tabela 2 e que apontou, em 2009, cerca de $30 \%$ de professores sem a titulação esperada pela LDB (BRASIL, 1996). 
qualidade. Tal perspectiva foi assumida nas orientações constantes nos incisos II e VI do art. 3..$^{\circ}$ e nos arts. $7 .^{\circ}$ e $8 .^{\circ}$ da política de formação docente (BRASIL, 2009a) e pareceu se sustentar no bom desempenho dos cursos de IES públicas no Sinaes. Em relação à pedagogia, os dados do CPC gerados para 2011 (INEP, [2013]) mostraram que daqueles cursos classificados nas faixas quatro ou cinco, $37 \%$ eram oferecidos por IES públicas, contra $29 \%$ das IES privadas. Se fossem observados todos os cursos de licenciatura, a diferença percentual cairia, mas o número de cursos das IES públicas classificados nas faixas quatro e cinco ainda seria maior: $42 \%$, contra $37 \%$ das IES vinculadas ao setor privado.

Apesar de os dados indicarem certa vantagem qualitativa entre os cursos públicos, a redação do inciso II do artigo $9 .^{\circ}$ da política de formação docente, alterada pelo Decreto n. ${ }^{\circ}$ 7.219, de 24 de junho de 2010 (BRASIL, 2010), abriu também a possibilidade de instituições de qualquer categoria administrativa oferecer turmas no Parfor. No que tange à qualidade da oferta dos cursos presenciais de pedagogia do Parfor, contrariando o senso comum, o cruzamento realizado entre os dados fornecidos pela Capes em janeiro de 2012, com os resultados apurados pelo CPC ano-base 2011 destacou a oferta desses cursos pelas IES privadas.

De acordo com os dados sistematizados ${ }^{72}$ na Tabela 8 , a oferta em foco concentrou cerca de $60 \%$ das matrículas de IES privadas nos cursos indicados pelo Sinaes como de muito boa qualidade (CPC 4). No contraponto, das 5.748 matrículas feitas pelas IES federais, 3.400 estavam em curso cuja qualidade apurada pelo Sinaes não foi registrada pela Capes, nem foi passível de identificação por esta pesquisa. Das referidas matrículas em IES federais que puderam ser associadas à qualidade apurada pelo Sinaes, apenas $5 \%$ estavam em cursos com CPC 4. Situação semelhante a das IES federais foi constatada nas IES estaduais, que apresentaram índice de $11 \%$ de alunos do Parfor em cursos presenciais de pedagogia com CPC 4, deixando um contingente de 3.931 discentes, de um total de 5.680, em cursos não associados aos resultados aferidos pelo Sinaes em relação ao CPC 2011.

\footnotetext{
${ }^{72} \mathrm{O}$ cruzamento sistematizado na Tabela 8 sofreu com a precariedade dos dados registrados pela Capes na Plataforma Freire, já apontado no capítulo 1.
} 
Tabela 8 - Distribuição dos alunos do Parfor Presencial matriculados em cursos de pedagogia, primeira licenciatura, por CPC 2011 e categoria administrativa da IES - janeiro/2012 (Brasil).

\begin{tabular}{|c|c|c|c|c|c|c|c|c|c|c|c|c|c|c|}
\hline \multirow{3}{*}{ IES } & \multicolumn{10}{|c|}{ Associados aos resultados do Sinaes } & \multirow{2}{*}{\multicolumn{2}{|c|}{ Não associados ${ }^{(\mathbf{1})}$}} & \multirow{2}{*}{\multicolumn{2}{|c|}{ Total Geral }} \\
\hline & \multicolumn{2}{|c|}{ CPC 2} & \multicolumn{2}{|c|}{ CPC 3} & \multicolumn{2}{|c|}{$\mathrm{CPC} 4$} & \multicolumn{2}{|c|}{$\mathrm{SC}^{(2)}$} & \multicolumn{2}{|c|}{ Subtotal } & & & & \\
\hline & $\mathrm{N}$ & $\%$ & $\mathrm{~N}$ & $\%$ & $\mathrm{~N}$ & $\%$ & $\mathrm{~N}$ & $\%$ & $\mathrm{~N}$ & $\%$ & $\mathrm{~N}$ & $\%$ & $\mathrm{~N}$ & $\%$ \\
\hline Total & 66 & $1 \%$ & 1861 & $36 \%$ & 948 & $18 \%$ & 2.263 & $44 \%$ & 5.138 & $100 \%$ & $\mathbf{7 . 5 7 8}$ & $100 \%$ & 12.716 & $100 \%$ \\
\hline Estadual & & $0 \%$ & 1536 & $88 \%$ & 199 & $11 \%$ & 14 & $1 \%$ & 1.749 & $100 \%$ & 3.931 & $52 \%$ & 5.680 & $45 \%$ \\
\hline Federal & 4 & $0 \%$ & 79 & $3 \%$ & 110 & $5 \%$ & 2.155 & $92 \%$ & 2.348 & $100 \%$ & 3.400 & $45 \%$ & 5.748 & $45 \%$ \\
\hline Privada & 62 & $6 \%$ & 246 & $24 \%$ & 639 & $61 \%$ & 94 & $9 \%$ & 1.041 & $100 \%$ & 247 & $3 \%$ & 1.288 & $10 \%$ \\
\hline
\end{tabular}

Fonte: Diretoria de Formação de Professores da Educação Básica/Capes (Plataforma Freire); Tabela Enade CPC 2011 (INEP, [2013]).

(1) Alunos vinculados aos cursos listados nos dados fornecidos a esta pesquisa pela Capes em janeiro/2012 e que não puderam ser associados aos resultados divulgados pelo CPC 2011. Esse caso refere-se a cursos oferecidos em mais de um campus, uma vez que não foi possível precisar qual sede institucional os alunos do Parfor Presencial de pedagogia estavam vinculados e ao consequente resultado aferido pelo Sinaes.

(2) $\mathrm{SC}=$ Sem conceito. Esse registro é gerado quando não há insumo para o cálculo do indicador (tais como nota de ingressantes ou concluintes) ou para os casos em que não houve ainda o reconhecimento do curso. O CPC é gerado apenas para cursos em processo de renovação de reconhecimento.

Os achados dispostos na Tabela 8 evidenciaram que mais da metade do total geral de alunos matriculados na pedagogia presencial do Parfor em 2012 (7.578) não puderam ser associados aos resultados alcançados por seus respectivos cursos no CPC 2011. Isso ocorreu porque, até 2012 (cerca de três anos após o início do funcionamento do programa), a Plataforma Freire desconsiderava as informações sobre a regulação dos cursos ou do seu código E-MEC, contrariando a expectativa do uso dos resultados avaliativos do Sinaes como requisito para sua oferta pelo Parfor. Nesse sentido, a tentativa desta pesquisa de fazer a associação nominal das listas do Parfor e Sinaes terminou limitada pelo fato de algumas das instituições ofertarem cursos de pedagogia em mais de um campus. Para esses casos, não foi possível identificar onde o aluno do Parfor Presencial estava matriculado (cerca de $70 \%$ dos casos de não associados). Ocorreu, ainda, casos de IES para as quais não foi possível encontrar qualquer curso de pedagogia nos resultados gerados pelo Sinaes, sem que tenha sido possível saber exatamente o porquê dessas ocorrências, mesmo supondo-se que tais cursos ainda não tivessem sido reconhecidos pelo sistema regulatório.

Diante das limitações impostas pela realidade, ainda assim optou-se por realizar a associação manual e apresentá-la conforme apareceram nas bases disponíveis. Entendeu-se que a própria forma precária como tais informações estavam sendo tratadas na Plataforma 
Freire se constituía numa informação valiosa para as análises realizadas neste trabalho, desde que consideradas dentro das limitações impostas pelas condições disponíveis.

Dessa forma, foi possível associar apenas 5.138 alunos dos cursos presenciais de pedagogia (cerca de $40 \%$ do total) aos cursos avaliados pelo Sinaes, a despeito de ser o sistema avaliativo a garantia da qualidade da oferta do Parfor. Considerando os dados disponíveis, foi possível observar, ainda, que: i) $90 \%$ dos alunos matriculados estavam em instituições públicas; ii) quase metade dos alunos do Parfor Presencial de pedagogia que frequentavam IES federais estavam em curso sem conceito (SC) $;^{73}$ e iii) quase $1 / 3$ (um terço) dos alunos matriculados em IES estaduais estavam em cursos de qualidade apenas suficiente. Constatou-se, pois, uma presença expressiva de alunos de pedagogia em cursos SC ou na faixa três do CPC, sem que tivessem sido identificados critérios claros que explicitassem o porquê da oferta de cursos pelo Programa no menor nível de qualidade aceitável, no caso das estaduais, ou sem qualidade atestada pelo Sinaes, no caso das federais.

Um terceiro conjunto de omissões do Parfor que contribuiu para caracterizar o que se chamou nesta pesquisa de Política de Qualidade pôde ser observado do ponto de vista específico do curso de pedagogia. O Parfor, e dentro dele o Parfor Presencial, assumiu uma visão pouco clara sobre a natureza desse curso como uma licenciatura. O inciso I do art. $7 .^{\circ}$ da política de formação docente (BRASIL, 2009a) pareceu diferenciá-lo dos demais cursos de formação de professores, contradizendo suas diretrizes curriculares que o definem exclusivamente como um curso de licenciatura. Essa imprecisão conceitual sobre a natureza do curso de pedagogia trazida no texto que regula a política de formação de professores pareceu ilustrar os embates acadêmicos em torno da base docente nas DCN do curso, bem como as preocupações expressadas no CTC-EB (ATA 2) sobre a possibilidade de a pedagogia seguir sua história de formação de especialistas em educação, e não necessariamente de professores. Porém, tais preocupações foram insuficientes para uma posição proativa em torno da qualidade dos cursos ofertados, reforçando a configuração da Política de Qualidade por meio da não ação da Capes na garantia do padrão de qualidade aludido na política de formação docente.

Por fim, o quarto conjunto de omissões que caracterizou a Política de Qualidade discutida neste trabalho referiu-se ao papel reservado aos Fóruns Estaduais Permanentes de Apoio à Formação Docente. Como já discutido, a criação desses Fóruns visou dar cumprimento aos objetivos da política de formação de docentes para a educação básica e teve

\footnotetext{
${ }^{73}$ Esses casos estão concentrados em duas instituições federais do Pará com processo de reconhecimento de curso em andamento no momento da apuração do CPC.
} 
por finalidade concretizar o regime de colaboração entre a União, os estados, o Distrito Federal e os municípios, por meio de planos estratégicos de formação inicial e continuada dos profissionais do magistério para as redes públicas da educação em suas respectivas Unidades da Federação. Porém, apesar de sua natureza colegiada e complexa, as decisões, sintetizadas no plano estratégico, vêm sendo submetidas ao MEC/Capes, sem que o processo avaliativo desse plano tenha sido definido pelo CTC-EB.

Considerando esse fato, destacaram-se três aspectos que contradizem o papel desse Fórum como entidade responsável por cumprir os objetivos da política de formação docente, nos termos do seu art. 4. (BRASIL, 2009a). Primeiro, os objetivos da política de formação de profissionais do magistério também podem ser cumpridos por meio de ações e programas específicos do Ministério da Educação, independentemente das ações previstas pelo Fórum no seu plano estratégico. Segundo, os Fóruns podem funcionar à revelia de secretarias estaduais de educação, mesmo estando definido o titular da referida pasta como seu presidente. Terceiro, a responsabilidade pela submissão dos documentos para a oferta de um dado curso não cabe ao Fórum, mas, sim, às IES. Nesse sentido, considerando esses aspectos que caracterizam a atuação dos Fóruns, não está claro o seu o papel na Política Nacional de Formação de Profissionais do Magistério da Educação Básica, o qual pudesse fazer dele um elo efetivo na organização das ações dentro da política de formação de docentes.

Sintetizando as evidências apontadas pelos dados analisados nessa seção, a perspectiva de qualidade da oferta de cursos presenciais de pedagogia do Parfor foi marcada por diversos embates, omissões e (não) ações que contribuíram para analisar a Política de Qualidade conforme proposto neste estudo. Os embates congregaram desde a questão das competências federativas, passando pela discussão entre a oferta pública versus privada e indo até as disputas em torno das competências avaliativas vinculadas à formação docentes no âmbito da burocracia do MEC. As omissões envolveram questões atinentes à perspectiva de longo prazo do Plano, ao cuidado em torno dos cursos oferecidos pelas IES públicas, à natureza complexa do curso de pedagogia e à atuação dos Fóruns Estaduais. Já as (não) ações se reportaram à inércia do poder público diante das repercussões da emergência do padrão de qualidade, estabelecido de forma não planejada, para a formação de professores da educação infantil e dos anos iniciais do ensino fundamental, conforme apurado na seção que segue. 


\subsection{PADRÃO DE QUALIDADE SINALIZADO PELO GOVERNO BRASILEIRO PARA A LICENCIATURA EM PEDAGOGIA}

O padrão de qualidade identificado nesta pesquisa para a formação de professores da educação infantil e dos anos iniciais do ensino fundamental no Brasil decorreu do pressuposto de que o vácuo da atuação governamental nesse campo fez emergir relações entre os critérios de qualidade utilizados pelo Sinaes para avaliar os cursos presenciais de pedagogia e aqueles assumidos pelo Parfor na sua dinâmica de oferta desses cursos. Como resultado, estabeleceuse, a partir dessa relação, um conjunto de orientações emanadas do governo brasileiro para a oferta com qualidade de cursos em análise.

Considerando o movimento encontrado na realidade empírica e a perspectiva epistemológica do hiperempirismo dialético, essa relação pôde ser caracterizada como ambígua. O conceito de ambiguidade dialética, trazido por Gurvitch (1987), permitiu considerar como ambivalentes situações que apontam sentidos diferentes, numa alusão à própria complexidade da natureza humana. No caso da Política de Qualidade, a ambivalência verificada entre critérios de qualidade para a oferta e avaliação com qualidade dos cursos de pedagogia foi entendida como imprecisões reais acerca daquilo que promove a adequada formação do professor da educação infantil e dos anos iniciais do ensino fundamental, conforme sintetizada, como segue:

a) Concepção de formação docente - os dados analisados evidenciaram, de forma difusa, parâmetros em torno de uma adequada concepção de formação de professores. Enquanto no Sinaes houve uma perspectiva de valorização da concepção de formação docente plural, conforme definida por Rios (2010), no Parfor houve o predomínio de referências à racionalidade prática, na acepção trazida por Araújo (2009). No entanto, pelo lado do Sinaes, observações sobre a concepção de formação de professores não integraram formalmente os instrumentos avaliativos, sendo apenas consideradas pelos avaliadores sensíveis a tal aspecto. Com isso, não puderam ser consideradas como um critério efetivo de avaliação da qualidade dos cursos de pedagogia pela baixa incidência entre os relatórios de avaliação in loco analisados. Já pelo lado do Parfor, as referências encontradas sobre a racionalidade prática foram contrabalançadas por ponderações sobre seus limites como proposta formativa, as quais permitiram reflexões dos coordenadores de forma a incorporar aspectos considerados positivos naquilo que foi definido como racionalidade crítica e técnica. Essa combinação de elementos visualizada nos dados do Parfor permitiria aproximá-lo, no conjunto dos cursos, de uma concepção plural para a 
formação de professores da educação infantil e dos anos iniciais do ensino fundamental, considerando a ideia de reciprocidade subjacente à separação da concepção formativa de professores entre as racionalidades técnica, prática e crítica. Todavia, as referências encontradas nas falas dos coordenadores foram demasiadamente dispersas para que, tomados os cursos individualmente, a concepção formativa plural caracterizasse o Parfor.

b) Perfil do egresso - as relações estabelecidas pelo Parfor e pelo Sinaes, mediadas pelas DCN da licenciatura em pedagogia, colocaram em destaque dois tipos de perfis profissionais de egressos do curso em foco: 1) o pedagogo numa versão ampliada, congregando os perfis de especialista/gestor em educação e o de professor da educação infantil e dos anos iniciais do ensino fundamental; e 2) o pedagogo professor, voltado prioritariamente às atividades de regência de classe. O primeiro tipo, como discutido na subseção 1.4.2, foi proposto como uma forma de superar a dicotomia entre o bacharelado e a licenciatura do curso de graduação em pedagogia, tendo a docência como elementochave do processo formativo. Nesse sentido, as DCN do curso garantiram a base docente como regra de formação do curso, mas deixaram entrever a possibilidade de que conteúdos ligados à gestão educacional em espaços escolares e não escolares se tornassem acessórios, notadamente no contexto no qual: i) não há sintonia entre o esforço necessário ao aprofundamento de conteúdos ligados à gestão e à realidade que permitam o exercício de cargos de direção ou coordenação em escolas ou sistemas educacionais independentemente do domínio desses conteúdos; ii) há uma efetiva carência de docentes formados para atuação estrita em sala de aula; e iii) inexiste a possibilidade legal de organização da formação em nível superior para o magistério da educação infantil e dos anos iniciais do ensino fundamental fora das diretrizes do curso de pedagogia. Com isso, o perfil do pedagogo formado no Parfor pode ser tanto voltado à regência de classe quanto à articulação da regência de classe com a gestão educacional. Já do ponto de vista do Sinaes, nem as avaliações in loco de cursos, nem o exame de desempenho discente foram capazes de apontar em qual dos dois sentidos identificados no perfil de formação do pedagogo se guiou o seu padrão de qualidade. O instrumento de avaliação in loco de curso pouco esclareceu sobre os parâmetros utilizados pelos avaliadores nesse item. Na mesma linha de imprecisão, o Enade tem-se concentrado em conteúdos voltados à formação geral, sem garantir o espaço esperado para aprofundar conteúdos específicos da docência e, principalmente, daqueles ligados à formação do especialista/gestor em educação, conforme pontuou Souza (2013). 
c) Desenvolvimento e organização do curso - os cursos do Parfor praticamente se dividiram entre aqueles que, em função das especificidades dos alunos-trabalhadores, criaram estruturas especiais para atender à periodicidade da oferta, à metodologia de trabalho e aos demais aspectos envolvidos na organização do curso e aqueles que deram aos alunos do Parfor o mesmo tratamento conferido aos demais alunos das IES. Observou-se, ainda, que apenas parte dos cursos desenvolveu práticas de planejamento da oferta das disciplinas, acompanhamento e orientação sobre a atuação metodológica do professor na condução das turmas, bem como a atenção e o acompanhamento mais próximo ao aluno para atender a carências específicas de alunos trabalhadores formados em serviço. Sobre esse aspecto, chamou a atenção o procedimento utilizado por alguns cursos das regiões Norte e Nordeste de dispensar os alunos das turmas do Parfor de atividades de leitura e de trabalhos analíticos individuais em torno de temas abordados no curso. No que se referiu ao Sinaes, não foram encontradas referências a indicadores e parâmetros sobre práticas desejáveis para o desenvolvimento e organização dos cursos. No que se referiu à inovação dos conteúdos curriculares, seguindo a definição de Gatti (2012), nem os cursos do Parfor, nem os critérios de qualidade presentes no Sinaes foram capazes de contemplá-la.

d) Estágio - esse componente curricular pouco foi contemplado em termos de parâmetros para a aferição de sua qualidade tanto em relação aos critérios presentes na oferta do Parfor quanto em relação às avaliações in loco do Sinaes, referentes a cursos presenciais de pedagogia. No caso do Parfor, constatou-se uma diversidade de arranjos entre áreas temáticas para a sua realização, sem que fosse possível identificar qual deles ofereceu significado concreto à qualidade na oferta do curso. Aliado a esse aspecto, identificou-se, ainda, uma diversidade ${ }^{74}$ de dinâmicas na condução dos estágios, sem que se pudesse estabelecer qualquer balizamento em torno da sua qualidade. Também os indicadores e parâmetros do Sinaes sobre a qualidade dos estágios não foram capazes de superar as imprecisões citadas: o CPC e o Conceito Enade não contemplaram a organização do estágio, e o instrumento de avaliação in loco contemplou apenas a observação do cumprimento, ou não, da carga horária obrigatória prevista.

\footnotetext{
${ }^{74}$ Como destacado na seção 3.3, os estágios no Parfor podem ocorrer por meio de observações empíricas, seguidas de discussão em sala de aula, passando por pesquisa com geração de relatório de aprofundamento teórico e intervenção e indo até à experiência de exercício profissional propriamente dita. Essa dinâmica tanto pode ser conduzida por meio da supervisão direta ou remota do professor-formador, com dispensa ou não do professor-aprendiz na área que ele atua, como também de áreas previstas no curso de formação, mas nas quais ele não atua.
} 
e) Atividades complementares - nesse aspecto de qualidade dos cursos presenciais de pedagogia, nem os critérios de qualidade utilizados pelo Parfor, nem aqueles presentes no Sinaes, conseguiram superar as (in)definições presentes nas DCN do curso. No Parfor, em específico, a grande quantidade de referências a atividades práticas presentes no documento legal (atividades complementares, atividades teórico-práticas e práticas de docência e de gestão educacional) levou a uma confusão conceitual entre a regra prevista e prática assumida nos cursos. Como consequência, evidenciou-se um comportamento disperso em relação a tais práticas, destacando-se certa tendência dos cursos em utilizar o espaço reservado às atividades complementares - associada no âmbito das diretrizes a momentos de aprofundamentos em campos específicos como educação especial e indígena, entre outras - para promover atividades corretivas das deficiências de formação básica, experiências culturais e no uso das TIC pelos alunos. Do ponto de vista do Sinaes, considerando os dados disponíveis, não foi possível realizar análises tão minuciosas acerca daquilo que se configurou como parâmetro de qualidade em relação às atividades complementares. No entanto, foi possível evidenciar o olhar mais aguçado dos avaliadores para o TCC e para as atividades de extensão. Destacaram-se, ainda, indefinições nos padrões de qualidade para os cursos de pedagogia tanto no Parfor quanto no Sinaes, no que se referiu ao desenvolvimento das atividades de iniciação científica, pesquisa e extensão em IES.

f) Corpo docente - o Sinaes define a adequação do corpo docente de um curso por meio da vinculação institucional, tempo semanal dedicado às atividades nas IES, titulação acadêmica e experiência profissional. No Parfor, tais critérios foram ressignificados de acordo com a necessidade dos cursos atenderem à demanda crescente por vagas, necessárias à expansão do plano formativo. Diferentemente do Sinaes, no Parfor, os processos de seleção de professores externos aos quadros da IES para atuar em suas turmas, bem como a realização de avaliações sobre a atuação deles, independentemente da vinculação com a instituição e do tempo dedicado (parcial ou integral), foram associados a características de qualidade do corpo docente.

g) Infraestrutura - no Parfor, aspectos relativos à infraestrutura dos cursos não mereceram comentários dos coordenadores entrevistados, permitindo considerar que, entre os cursos do Plano, esse indicador pode contribuir pouco para diferenciar a qualidade deles. Aparentemente, a infraestrutura tornou-se apenas um elemento básico para $o$ desenvolvimento das atividades formativas. Uma vez atendida, a infraestrutura passou meio despercebida. Com isso, inferiu-se a possibilidade de que essa dimensão não seria 
capaz, por si só, de ampliar a distância da qualidade entre os cursos. Já do ponto de vista do Sinaes, a dimensão infraestrutura congregou indicadores variados, sem, contudo, reportar-se a aspectos concretos da qualidade do curso. No caso do CPC, o indicador de qualidade da infraestrutura referiu-se exclusivamente ao item da percepção dos alunos sobre a disponibilidade de equipamentos para aulas práticas. No caso dos instrumentos de avaliação in loco, diz respeito a uma concentração de itens, muitos deles desconectados da organização didático-pedagógica, conforme analisado na seção 3.1.

Adicionalmente, encontrou-se uma imprecisão basilar na definição de curso assumida por Parfor e Sinaes. Enquanto que para o Plano foi comum encontrar a oferta de turmas fora do município da sua sede sem que essa oferta se individualizasse como um curso diferente, para o sistema avaliativo, conforme definido no Decreto n. ${ }^{\circ} 5.773$, de 9 de maio de 2006, qualquer configuração de turma oferecida fora da sede deve ser considerada como um curso específico, mesmo que oferecido pela mesma IES (BRASIL, 2006a). Inclusive nos casos em que a turma do Parfor se estabeleceu no mesmo município da sede do curso, foi comum encontrar coordenadores de cursos exclusivos das turmas do Parfor e com a atuação diferenciada do coordenador das demais turmas do curso ou, até mesmo, a implementação de projeto pedagógico diferenciado para as turmas do Parfor, assim como a contratação de corpo docente próprio para atendê-las.

Tal situação ambivalente do Parfor, na qual turmas assumem a configuração de um curso específico, não tem sido admitida nas regras oficiais. Também a potencialidade de conflito dessa situação com as regras de regulação do Sistema Federal de Ensino Superior não foram tratadas. O sistema informatizado que controla o Parfor - Plataforma Freire - vinha controlando, apenas, os municípios beneficiados com as vagas para a formação docente, sem reportar qual curso sede foi o responsável pela vaga. Tal omissão só foi parcialmente resolvida a partir dos registros das novas ofertas de 2013, quando se passou a exigir a vinculação formal das turmas do Parfor aos cursos regularmente reconhecidos para as novas ofertas. Porém, tal exigência solucionou apenas parte do problema - o da formalização. Considerando a necessidade de ampliar a capacidade das IES em atender, além da sua demanda regular, à demanda de formação dos professores das redes estaduais e municipais de educação básica, o Parfor vem fomentando a contratação de professores-formadores fora dos quadros institucionais, bem como os deslocamentos necessários ao desenvolvimento das atividades formativas fora da sede do curso. Com isso, mesmo controlando a responsabilidade dos cursos sobre as turmas, não pareceu ser razoável considerar que a qualidade apurada pelos instrumentos avaliativos do Sinaes possa ser transferida para os arranjos em torno da 
organização didático-pedagógica, da infraestrutura e do corpo docente, criados na oferta de algumas turmas do Parfor. Não há mecanismos que atestem que turmas de um curso, ofertada em condições diferentes daquelas que ensejaram a geração de nota pelo Sinaes, tenham qualidade equivalente.

No caso do Parfor foi possível apurar, a partir da amostra analisada e dos condicionantes destacados, que existem cursos que ofereceram turmas fora de sede sem configurá-las como cursos distintos, como rege a legislação. Além disso, há muitos casos de turmas que possuem de fato o formato de um curso diferente daquele que as originaram por possuírem coordenadores, projetos pedagógicos e/ou corpo docente diferenciados. Por fim, efetivamente, existem turmas do Parfor dentro de cursos regulares oferecidos pelas IES, conforme sugerem as regras de regulação da educação superior prevista na Portaria 40/2007 (BRASIL, 2007d) e que, portanto, estariam contempladas pelos resultados avaliativos do Sinaes para os seus respectivos cursos por estarem integradas organicamente a ele.

Essa realidade permitiu considerar que o efetivo alcance de qualidade dos critérios do Sinaes sobre a oferta do Parfor não tem sido linear como defendida pela Direção da Capes nas discussões sobre o tema, travadas no âmbito do CTC-EB. Os dados empíricos evidenciaram a existência de algumas turmas que, pela dinâmica da proposta de oferta do Parfor, podem não ser alcançadas pelo sistema avaliativo. Entre outros exemplos que ilustram esse entendimento, estão as declarações do Coordenador P que informou "[não saber ao certo] se os alunos do Parfor realizariam as provas do Enade juntamente com os demais alunos do curso" e a do Coordenador G, que deixou entrever que a turma do Parfor se configurou como um curso experimental, com única edição e, portanto, alcançado pelas regras regulatórias de forma limitada.

Além disso, a ideia de que o Sinaes seria capaz de garantir um padrão de qualidade para a oferta de cursos pelo Parfor pareceu ceder lugar a uma perspectiva individual e nuançada de sentidos para a qualidade da sua oferta. Os critérios de qualidade destacados nas turmas do Parfor pouco representaram aqueles identificados nos relatórios do Sinaes sobre a avaliação in loco de cursos. Em verdade, os dados apontaram que quando os critérios se mostraram similares, tal concatenação ocorreu mais em função da ausência de parâmetros de ambos os critérios sobre o significado da qualidade na formação do professor da educação infantil e dos anos iniciais do ensino fundamental do que propriamente pela concordância em torno deles.

Dessa forma, a comparação entre os critérios de qualidade do Parfor e do Sinaes em torno de cursos presenciais de pedagogia evidenciaram relações dialeticamente ambíguas, 
possivelmente decorrentes da tensão entre a rigidez dos indicadores isomórficos e pouco representativos assumidos pelo Sinaes e a força concreta da realidade na qual o Parfor se inseriu. Conforme explicou Gurvitch (1987, p.195), “as totalidades humanas em marcha, em seus movimentos de totalização ou de destotalização, implicam uma grande parte de ambiguidade; esta se exacerba até chegar à ambivalência entre estruturas e organizações". No caso em estudo, o processo de totalização inerente à visão sistêmica do Parfor, Sinaes e DCN da pedagogia como um todo integrado na Política de Qualidade permitiu visualizar as ambiguidades estabelecidas entre os critérios de qualidade dos dois primeiros, mediados pelo último, como ponto de partida que deu estrutura ao fenômeno em foco. Além disso, as ambiguidades identificadas entre os critérios de qualidade do Parfor e do Sinaes em torno dos cursos de pedagogia pareceram estabelecer um movimento de exacerbação dos critérios de qualidade trazido pelos componentes de forma a torná-los ambivalentes e, portanto, imprecisos.

Explicando teoricamente a relação dialética da ambiguidade, Gurvitch (1987) sugeriu que ela, além de se configurar como ponto de partida de uma totalidade, pode servir também como obstáculo ao seu equilíbrio, não se constituindo como uma presença indispensável à manutenção do sistema considerado. Transpondo essa ideia para a Política de Qualidade, aparentemente, ao mesmo tempo que as imprecisões listadas anteriormente deram forma ao fenômeno, parecem contribuir para o seu desequilíbrio, desarticulando o significado do que representa um bom curso de pedagogia no contexto brasileiro, seja pela inexatidão de critérios, seja pela limitada repercussão da qualidade representada pelo Sinaes no dia a dia do Parfor (cursos presenciais de pedagogia).

O conjunto de dados disponíveis sobre a realidade dos cursos presenciais de pedagogia do Parfor, quando inserido no contexto da regulação exercida pelo Sinaes, ilustrou a baixa legitimidade dos critérios de qualidade do sistema avaliativo. Dos 17 coordenadores entrevistados, quase um terço deles (seis coordenadores) declararam expressamente não utilizar os resultados exarados pelo Sinaes, notadamente por meio do Enade. Dos onze restantes, apenas três assumiram ter realizado ajustes em seus projetos pedagógicos ou abordagens de conteúdos curriculares. Os outros oito indicaram a possibilidade de uso das informações geradas pelo sistema avaliativo sobre o curso, mas teceram críticas em relação aos limites trazidos por seus resultados. Com isso, a micorregulação baseada no Sinaes foi baixa na amostra analisada, favorecendo uma diversidade de sentidos para a qualidade do Parfor, também catalisada pela ausência de parâmetros estabelecidos pela Capes/CTC-EB em torno de um "padrão de qualidade". 
Nas IES estaduais, foi localizada a maior parte dos casos identificados de não uso dos resultados do Sinaes na dinâmica dos cursos. Essa situação foi mais frequente quando o coordenador do curso de pedagogia do Parfor não era o mesmo do curso regular ou os projetos pedagógicos eram diferentes daqueles das demais turmas. Além disso, no caso das IES estaduais, o não uso dos resultados avaliativos externos pareceu estar associado a certa indiferença institucional, provocada provavelmente pela falta de repercussão do conteúdo regulatório federal no cotidiano dos cursos, conforme expressado nas falas a seguir destacadas:

No que eu tenho conhecimento, houve uma divulgação interna [dos resultados do Sinaes]. Não tenho uma informação muito mais precisa sobre isso (Coordenador F).

Com relação ao Enade, o Sinaes, a gente tem algumas discussões, mas elas são muito poucas. Que eu tenha participado não foram tantas. (Coordenador K).

A [IES] tem uma política de avaliação institucional, mas eu não sou [...] Eu não faço parte dessas discussões maiores (Coordenador M).

Por outro lado, não se pôde atribuir o não uso dos resultados do Sinaes entre os cursos chancelados pelo Parfor apenas em razão de sua categoria administrativa. Mesmo entre aqueles coordenadores que assumiram algum tipo de uso dos resultados do Sinaes, observouse pouca aderência aos critérios do sistema avaliativo. Talvez essa baixa aderência esteja vinculada à pouca participação da comunidade universitária na definição dos referidos critérios (legitimação política), conforme esclareceram alguns coordenadores:

A discussão [sobre os resultados do Sinaes] fica mais em torno das principais deficiências apontadas pela prova [do Enade]. [Tem mais o sentido de] informe para tomar conhecimento, do que alterar o projeto... Isso por um lado, para mim, é bom. Por outro, mantém a contradição. Ao final e ao cabo, não traz consequências para gerir o curso, levando em consideração essa avaliação. [Quando você adere,] vai abandonando os propósitos originais do curso e fixando sua atenção na avaliação de larga escala como é o caso do Enade. [Então,] você começa a alterar [suas próprias ideias e projetos] para o curso. Isso para mim é bastante perverso. É um movimento inverso ao que a gente, do ponto de vista discursivo, defende. Mas acontece... Então, quando o Enade tem suas provas e nós temos o resultado, o colegiado dos cursos se mobiliza para verificar quais são as falhas, do ponto de vista do Enade, para fazer as correções internas (Coordenador J).

Quanto ao Enade, eu acho que a proposta é boa, mas acho que ainda nós não conseguimos acertar. Acredito que a proposta é interessante, mas não pode ser aquela coisa pontual, [...] Eu percebo que precisamos, nós professores das universidades públicas brasileiras, nos apropriar do Enade para trabalhar melhor junto aos nossos alunos (Coordenador P).

É claro que nós olhamos a prova, analisamos [... ] Comentamos que são colocados aspectos que não são necessariamente enfatizados no próprio currículo de formação. [Essa prova] não considera as especificidades dos currículos de cada região, de cada 
universidade [...] Os processos de avaliação que vão ocorrendo por dentro das universidades [são mais importantes] (Coordenador G).

Outro aspecto que chamou a atenção no tratamento dado por cursos de pedagogia do Parfor aos resultados advindos do Sinaes foi a perspectiva de preparação específica de alunos para a realização do Enade. Essa possibilidade se evidenciou em dois cursos da amostra de categoria administrativa privada, os quais sinalizaram a preparação do formando para realizar a prova do Enade, sem se reverter, efetivamente, em melhoria dos currículos ou práticas pedagógicas:

\begin{abstract}
A gente vai manter o que vem fazendo. Ou seja, resumidamente, trabalhar as questões do Enade nas disciplinas tanto na avaliação continuada, quanto na avaliação final. [...] Uma coisa que a gente levantou e não fechou ainda é, por exemplo, fazer uma espécie de simulado, naqueles mesmos moldes [do Enade]. Essa sugestão veio dos alunos egressos. A gente veria o tempo para responder, e se acostumaria com o formato da prova. Porque uma coisa é trabalhar as questões isoladamente, outra é juntar e ter uma situação dessa (Coordenador C).
\end{abstract}

$\mathrm{Na}$ [IES] tem essa preocupação. Eles criaram agora um tal de provão [...] para o treinamento [dos alunos] (Coordenador B).

Os dados destacaram ainda que, para boa parte das IES, os resultados do Sinaes, notadamente do Enade, foram considerados como mais um dos insumos, entre aqueles disponíveis às IES, para pensar e repensar os conteúdos e currículos. Nesse sentido, essa reflexão não se fez de forma descontextualizada, sendo os resultados do processo avaliativo externo um dos pontos para se pensar a melhoria do curso, sem que, no entanto, fossem tomados como padrão da qualidade a ser buscada:

$\mathrm{Na}$ semana de planejamento a gente pega o resultado, avalia as questões nas quais o grupo não foi tão bem. Mas quando o grupo não vai tão bem, foi por conta dos alunos que fizeram boicote [...] Mas é a natureza de como a questão foi elaborada. Isso a gente faz no começo do ano. Nós não somos escravos do Enade. [...] Os alunos têm feito a prova com aquele embasamento que a gente tem dado nas aulas. Não tem nenhuma preocupação específica de formar ninguém para o Enade. [...] A prova, por si só, não é sinal para mudar o nosso rumo de formação (Coordenador N2).

Então há uma discussão permanente. [Em] vários momentos do primeiro semestre e [...] do segundo semestre nós nos reunimos para discutir como será a avaliação ou o instrumento a ser modificado e encaminhado à comissão interna de avaliação. Ou, no retorno dos dados, como trabalhar com esses dados. [...] Agora nós viemos de estudo de dois anos do nosso currículo novo, que emergiram sugestões [para implantá-lo] já no segundo semestre. Isso vem de conversas com os alunos, de estudos, entrevistas, dessas avaliações para fazer as alterações necessárias. Por exemplo, nós percebemos que vários egressos do curso de pedagogia acabam assumindo coordenações ou, até mesmo, direções de escolas de educação infantil. Esse fator foi importante para nós trabalharmos nos currículos (Coordenador I). 
A gente leva em consideração alguns aspectos, mas o que eu quero dizer é que isso, uma avaliação externa, não serve de parâmetro [...] Ela acaba registrando um olhar para que a universidade seja de excelência [segundo] alguns precedentes, quando eu acho que na verdade a avaliação é importante para uma autoavaliação daquilo que a gente vem fazendo [...] (Coordenador $\mathrm{G})$.

Nesse sentido, observou-se que apesar de a condução da política de formação de professores indicar o Sinaes como a possível fonte da garantia da qualidade dos cursos, suas orientações pareceram não impactar a organização ou o planejamento didático-pedagógico de grande parte dos cursos de pedagogia oferecidos pelo Parfor. No entanto, a despeito da pouca aderência aos critérios do Sinaes, a interação com eles no dia a dia dos cursos geraram uma concepção de qualidade, que pareceu permear a Política de Qualidade, conforme mais bem detalhado na subseção a seguir.

\subsubsection{Concepção de qualidade}

A discussão teórica presente no capítulo 2 desta tese assumiu o conceito de qualidade na educação superior como amorfo, sem forma pré-estruturada, mas que ganhou contornos a partir de critérios definidos pelo contexto histórico-social no qual o objeto está inserido. Numa visão linear do fenômeno da qualidade, poder-se-ia pensar que esse entendimento decorreria de uma visão indutiva, na qual, primeiro, se operacionalizaria a qualidade por meio de critérios de oferta e avaliação de cursos, para depois se identificar os princípios que estariam por trás deles (concepção de qualidade). Tal visão se contraporia, portanto, àquela presente nos trabalhos de Harvey e Green (1993), Morosini (2001), Dias Sobrinho (2008a) e outras contribuições apresentadas pela revisão de Bertolin (2007), que trouxeram referências de concepções de qualidade racionalmente categorizadas, a partir das quais seria possível definir o seu significado na realidade da educação superior. No entanto, ao contrário de contrapor-se à literatura, o conceito de qualidade assumido neste trabalho apenas dialetizou a relação entre os princípios orientadores e o significado que o conceito assume em cada contexto histórico.

Para ilustrar essa perspectiva dialética da relação entre qualidade, como significado em si, e concepção de qualidade, como orientações gerais para a definição desse significado, encontrou-se no Sinaes o exemplo que alertou sobre a possível inexistência de caminho unidirecional entre eles. Em geral, a literatura tendeu a classificar os princípios orientadores do referido sistema avaliativo dentro de uma concepção social ou emancipatória de qualidade (RISTOFF; GIOLLO, 2006; BARREYRO; ROTHEN, 2008). Porém, o que se observou no 
processo de seu desenvolvimento foram críticas no sentido de que tal concepção estaria sendo descaracterizada pelos desdobramentos do Sinaes dentro de uma visão ranqueadora e mercadológica de qualidade (BARREYRO, 2008; DIAS SOBRINHO, 2008b; POLIDORI, 2009). Partindo desse exemplo do Sinaes, questionou-se o entendimento de que concepções de qualidade balizariam linearmente, de forma racional e ajustada, a concretização (significado) da qualidade na realidade empírica.

Outra questão que se apresentou em relação às concepções de qualidade da educação superior foi a tendência de a literatura revisada contrapor categorias identificadoras dessas concepções. $\mathrm{Na}$ análise das contribuições teóricas discutidas na seção 2.1 deste trabalho, considerou-se que as diferentes visões sistematizadas por elas não pareceram gozar, necessariamente, de uma relação de polarização. Aparentemente, tais concepções trouxeram a possibilidade de identificar dimensões/faces da qualidade, que poderiam atuar de forma complementar, ou não, no uso operacional do conceito e, portanto, no significado efetivamente assumido por ele, seja na estruturação da oferta de cursos de nível superior, seja nos seus processos avaliativos.

Considerando essas ideias, propôs-se o entendimento de que quando se pensa, planeja ou discute qualidade da educação superior, nenhuma das suas possíveis concepções - também entendidas como sentidos que multifacetam o conceito na sua totalidade - estão previamente afastadas ou incluídas na apropriação da ideia de qualidade na realidade concreta. Pelo que se pôde considerar, essas concepções pareceram concorrer igualmente, apresentando mais ou menos força conforme se desenrolam os embates e interações entre aqueles diretamente envolvidos nos seus resultados práticos, sem que fosse possível assumir um lado permanentemente vencedor. A dinâmica da educação superior, visualizada como um sistema, pareceu ressignificar o que se assumiu por qualidade a cada contexto histórico.

Dentro dessa perspectiva, foi possível construir uma visão dialética da concepção de qualidade presente na política em foco. Como contexto, encontrou-se, de um lado, o fato de que indivíduos assumiram o papel de docentes da educação infantil e dos anos iniciais do ensino fundamental, sem partilhar do corpo teórico, legal, ético e estético que define o pedagogo como profissional diplomado e, do outro, um sistema avaliativo isomórfico sem uma orientação prévia que balizasse a construção da oferta de um curso com qualidade. Inserida nesse contexto, a ideia de qualidade em questão tomou forma por meio dos conhecimentos, habilidades e atitudes presentes no perfil profissional dos egressos, conforme explicitaram os coordenadores entrevistados. Para eles, qualidade da educação superior significa: 
Oferecer ao aluno bases teóricas e práticas nas quais possam atuar com competência. Trabalhar não só a parte teórica, mas também uma parte prática que possam oferecer uma atuação com competência no mercado de trabalho. Na educação, na escola, na sala de aula, na gestão escolar, na orientação, na supervisão, na direção. Enfim, em todas as formações que o curso de pedagogia proporciona (Coordenador D).

[...] quantidade de conhecimento incorporado pelo estudante [...]. Existem certos conhecimentos que são necessários para a prática profissional [...]. Na medida em que [o curso] consegue alcançar esse objetivo, ele contribui para o que se chama de 'profissionalização' (Coordenador J).

[...] uma plena formação de professor, [vinculada a] atitudes, conhecimentos, habilidade [e a uma] ética profissional, acoplada à questão do trabalho. (Coordenador L).

Possibilitar o pleno desenvolvimento de sua formação, possibilitando aspectos acadêmicos e culturais [...] (Coordenador N2).

[não só oferecer] biblioteca, mas também disponibilizar ao professor espaço para ele produzir, criar, construir (Coordenador $\mathrm{P}$ ).

A partir da contribuição de Dias Sobrinho (2008a), essa significação de qualidade presente nas falas dos coordenadores poderia ser vinculada ao credenciamento profissionalização - para o emprego e, por consequência, ser rotulada como oriunda de uma perspectiva de qualidade advinda do mercado, conforme segue:

A formação de qualidade é aquela que permite ao indivíduo ter um pensamento adequado ao mundo em que vivemos. O que exige uma flexibilidade, uma perspectiva de inovação de alguém que quer sempre se renovar naquilo que pensa e naquilo que faz (Coordenador $\mathrm{H}$ ).

Porém, há que se ponderar que o significado expressado no âmbito do Parfor, ao contrário de negar a possibilidade de atuação ético-social do egresso, fez emergir uma visão complementar entre a formação teórico-prática para o desempenho profissional e a perspectiva de atuação cidadã do pedagogo formado pelo Parfor, conforme detalhado pelos coordenadores:

A gente tem que estar preocupado com uma formação sólida, que realmente sirva às demandas da sociedade [...] No nosso caso, principalmente da educação básica (Coordenador C).

[Qualidade é que] o aluno que aprenda [...] Que saiba discernir o problema que está no texto, o problema que está em uma discussão. Que consiga discutir aquilo que está lendo e ao mesmo tempo consiga se posicionar. E não se posicionar com o senso comum ou com militância. Se posicionar [sobre o] conteúdo, categoria de análise e apropriação dos autores (Coordenador F).

Qualidade é uma qualidade política, teórica, prática, metodológica que envolve um posicionamento problematizador frente a determinadas questões. (Coordenador $\mathrm{G}$ ) 
Nesse sentido, depreendeu-se que a concepção de qualidade presente nos relatos analisados destacou não só a questão da profissionalização dos professores-aprendizes, como também o importante papel social a ser desempenhado por eles quando do desenvolvimento do seu trabalho. Essa perspectiva pareceu refletir o valor de que a aquisição de competências para a atuação profissional no mercado de trabalho não descarta uma postura crítica, corroborando o entendimento de Libâneo (2008) sobre características de um programa adequado para a formação de docentes. Considerando esses dados, foi possível depreender que a preocupação técnica no processo de formação dos pedagogos no Parfor Presencial não apareceu dissociada de uma postura engajada socialmente.

Reforçando esse entendimento, quando os coordenadores foram perguntados sobre a concepção de qualidade na formação trazida pelo curso, as respostas deixaram entrever que a ênfase técnica levaria à construção da melhoria da educação básica, por meio da ressignificação da prática dos professores em formação, conforme trechos destacados a seguir:

[É importante a] formação teórica, mas voltada sempre para a construção ideal da educação brasileira. Ou seja, a relação teoria e prática. Isso tudo tendo em vista a possibilidade [de os sujeitos transformarem] a realidade em que vivem [...] uma visão crítica, uma visão reflexiva capaz de fazer [com] que esse aluno se situe no contexto maior, na realidade onde ele vive, onde ele trabalha [...] Essencialmente para formá-los dentro de uma perspectiva de uma educação que tenha sentido para as pessoas (Coordenador I).

Por outro lado, para nós professores, é interessante porque eles contam as suas vivências em sala de aula, então nós buscamos essas reflexões para essa práxis dele. (Coordenador M).

Uma visão de que a teoria e a prática são indissociáveis. Existe essa articulação teórica e prática e a gente valoriza muito a questão da formação teórica do aluno, articulada a conhecimentos práticos, mas a concepção teórica aqui é muito bem consolidada. (Coordenador N1).

Dessa forma, a ressignificação da prática foi apresentada de forma a permitir desenvolver, complementarmente, competências profissionais para o mercado de trabalhos e ao mesmo tempo permitir a reflexão crítica da realidade, no sentido de uma perspectiva de pluralidade presente na análise de Rios (2010). Os dados indicaram, ainda, que a preocupação com a prática, expressada pelos coordenadores no processo de formação dos docentes, apareceu vinculada ao desenvolvimento de habilidades profissionais inseridas no quadro teórico-científico já construído (o qual não era dominado pelos professores-aprendizes), e não necessariamente ao avanço das fronteiras desse conhecimento (inovação), conforme sugerido 
por Schön (2000) em sua tese de reflexão-na-ação. Nas suas falas, os coordenadores afirmaram que [...]

[...] o nosso grande desafio é repensar esse cotidiano da escola com as alunas. Então, os professores tem que fazer o caminho inverso: considerar as experiências que as alunas trazem do cotidiano da escola, para que essas reflexões tenham sentido e essa prática pedagógica seja reinventada [...] A intenção dos professores é que seja permanente a relação teoria e prática (Coordenador A).

Mas que, diferente de alguns cursos e da própria proposta do Parfor que ficam exigindo procedimentos inovadores, novos materiais. Diferente dessa concepção, digamos empreendedora, o curso tem clareza de que há elementos científicos, filosóficos que estão vinculados há área de pedagogia que não são dominados por esses estudantes que, embora estejam nas redes não tiveram uma formação inicial em pedagogia. [Esses conhecimentos] não são dominados por eles (Coordenador J).

Os alunos do Parfor já vêm com uma prática. Isso é bom e às vezes não é tão bom. No começo, eles pensam que como eles já tinham prática, já tinham tudo. À medida que eles vão verificando que essa prática pode ser melhor, que existem formas e jeitos melhores de fazer, eles vão compreendendo [novas formas de atuar]. (Coordenador K)

Por outro lado, não se pôde negar que a dinamicidade do contexto da educação básica, bem como o desafio imposto por realidades diversas e que fazem parte do cotidiano dos professores em formação termine por criar, por si só - sem o planejamento prévio ou deliberado por parte do curso -, oportunidades de se refletir-na-ação e de despertar o talento artístico-profissional, aludido Schön (2000). Inclusive, a própria prática docente desses professores-aprendizes passou justamente por essa construção de caminhos para lidar com questões cotidianas para as quais, embora pudessem existir respostas teóricas prontas, demandaram deles uma ação criativa pelo não acesso ao conhecimento teórico já sistematizado. Reforçam essa possibilidade alguns relatos dos coordenadores de curso ao afirmarem que a discussão das vivências dos estudantes esteve sempre presente na metodologia do trabalho de formação, visando [...]

[...] trabalhar com o aluno essa veia de pesquisador porque vai a uma escola, detecta um problema, pensa, reflete junto com o grupo e tenta desenvolver uma proposta de intervenção. Então a gente recebe por essas disciplinas, pelas falas dos professores. [Os alunos] vão amadurecendo essa capacidade investigativa, de elaboração de material (Coordenador E).

Que [o aluno] possa atuar na educação básica com novas teorias a frente dessas novas discussões sobre educação brasileira. Que ele possa fazer realmente isso. Tenha uma nova prática a partir dessa reflexão (Coordenador M).

Além disso, ainda que a discussão feita pelos coordenadores em torno da sua compreensão de qualidade os levasse a associá-la à avaliação e à regulação da educação 
superior, essa perspectiva pareceu corroborar o entendimento construído no marco teórico desta pesquisa de que o conceito de qualidade na educação superior pressupõe uma articulação sistêmica entre os indicadores que caracterizam a realidade, a sua valorização ou julgamento (avaliação) e as ações decorrentes do quadro refletido da realidade (regulação).

Assim, para parte dos entrevistados, falar em qualidade da educação superior no Brasil passa pela profissionalização do professor, mas também conduz à diferenciação entre IES públicas e privadas em torno da qualidade envolvida no processo dessa formação. Do ponto de vista de alguns coordenadores, existe uma ficção de que não há compromisso das IES privadas com o processo formativo de seus alunos. Conforme afirmaram,

[...] tem um componente que é muito presente, que ainda está muito vivo: a questão do público e privado. Eu sou de uma IES privada, eu não tenho dúvida que aquilo que a gente oferece é um curso de qualidade. Então eu acho que de uma forma geral, as pessoas têm uma visão muito restrita (Coordenador C).

[...] sempre teve um conceito que a universidade pública é quem tem uma formação de qualidade. As IES privadas são colocadas como se [seus] cursos não tivessem qualidade. Eu não concordo. Eu acho que isso não é verdade (Coordenador D).

Já do ponto de vista explicitamente colocado por, pelo menos, dois coordenadores de IES estaduais ouvidos, pensar em qualidade da educação superior no Brasil tende a reforçar a superioridade da oferta pública ante a oferta privada, conforme se observou nas transcrições a seguir:

Eu vejo [a qualidade] sob a perspectiva da universidade pública e da particular. A
qualidade da formação na faculdade particular é uma coisa, na pública é outra [na
pública é melhor] (Coordenador M).
A gente mexe com pontos que vão além da vontade de formar um bom professor,
principalmente quando se refere ao ensino superior particular. O que a gente vê em
alguns casos é uma massificação de formação sem preocupação com a formação
sólida e crítica do professor. Tenho acompanhado o número de alunos por sala de
aula que a rede particular coloca: há precarização da formação do professor
(Coordenador N1).

Destacou-se que essa discussão polarizada sobre o público e o privado na oferta de qualidade apareceu não só nas falas dos coordenadores, mas também nos embates políticos discutidos na seção anterior. Porém, do ponto de vista da elaboração de um conceito de qualidade centrado em critérios, não foram encontrados argumentos dos coordenadores que, fora do senso comum, apresentassem características objetivas sobre a qualidade de cursos, as quais pudessem corroborar ou refutar a sua associação com a categoria administrativa da IES. 
Além do aspecto público versus privado na qualidade dos cursos, nas falas dos coordenadores apareceram também reflexões sobre o caráter ranqueador associado à noção de qualidade da educação superior no Brasil. Nessa perspectiva, as reflexões trouxeram algumas ponderações sobre indicadores do Sinaes, conforme segue:

\footnotetext{
Quando se fala em qualidade, acaba-se reduzindo muito essa questão aos índices. [...] Então, me parece um pouco desconfortável o esvaziamento dessa discussão, que torna tudo muito simplista em torno de índices (Coordenador A).

Está muito relacionado com as próprias avaliações propostas pelo MEC. O Sinaes. Qualidade é aquilo que tem 4 ou 5 no Enade. Não teve [essa nota], não tem qualidade [...] Nem sempre os números dizem tudo (Coordenador B).

Quando você atrela a qualidade a ranqueamento, escala, a número, isso me assusta. $\mathrm{Eu}$ acho que a educação deve promover o homem na sua integralidade, nas suas possibilidades educacionais (Coordenador E).
}

Em síntese, as discussões dos entrevistados em torno da concepção de qualidade da educação superior destacaram, como seu core, aspectos voltados ao compromisso éticoprofissional-social do egresso formado. Nesse sentido, e ante o aparente silêncio do Sinaes em torno de uma concepção de qualidade para cursos de formação de professores, de forma geral, e de pedagogia de forma específica, a concepção de qualidade que permeou a relação em estudo pareceu evidenciar uma perspectiva de articulação da teoria acadêmica com a prática profissional do professor-aprendiz, em torno de uma atuação transformadora na educação básica, em um sentido muito próximo àquele trazido legalmente pelos incisos I e II do art. $2 .^{\circ}$ do decreto que estruturou a política de formação de professores (BRASIL, 2009a).

No entanto, o processo de apropriação dessa ideia na realidade da Política de Qualidade deixou entrever dúvidas sobre a sua capacidade de gerar, de fato, aquilo que se desejou como princípio orientador. Tal questionamento se fez possível tendo em vista que a concepção de qualidade evidenciada se reportou ao domínio, pelos pedagogos em formação, de conhecimentos teóricos e práticos para a sua emancipação e o desenvolvimento econômico e social da nação, mas não orientou quais conhecimentos teóricos e práticos contribuem para o resultado esperado.

Os critérios de qualidade presentes nas práticas do Parfor e do Sinaes indicaram que os conhecimentos teóricos podem se reportar tanto aos conteúdos relativos à docência stricto sensu (definidos no âmbito do Sinaes/Enade como aqueles pertinentes aos conteúdos a serem ministrados aos alunos da educação infantil e dos anos iniciais do ensino fundamental e suas didáticas), acompanhados, ou não, daqueles que se referem mais diretamente aos conhecimentos de gestão de sistemas e de espaços escolares e não escolares. Entre uma e 
outra possibilidade de conteúdos teóricos, também não ficou clara a medida desejável daqueles conhecimentos que podem ser enquadrados como fundamentos (tanto para a docência, quanto para a gestão), bem como os que definem o atendimento às demandas de educação especial, de jovens e adultos, indígena, etc. No que se referiu aos conhecimentos práticos, os critérios que operacionalizaram a concepção de qualidade da relação em estudo também não foram capazes de balizá-los. As práticas articuladoras da teoria com a realidade, tanto no âmbito do Sinaes quanto no âmbito do Parfor, foram as mais variadas possíveis. Assim, a concepção de qualidade encontrada, aparentemente não se reverteu em orientações que pudessem materializar o seu significado na realidade da política em foco.

Conforme demonstrado, o padrão de qualidade emergido das relações entre os critérios de qualidade do Parfor e do Sinaes para as licenciaturas presenciais de pedagogia mostrou-se pouco capaz de garantir a utilização de parâmetros de ação minimamente compartilhados pelos cursos. Sob a égide do Sinaes, tal padrão se apoiou em critérios que não identificaram adequadamente os parâmetros utilizados na aferição da qualidade dos cursos em questão. Sob a égide do Parfor, foram tantos os sentidos possíveis para o que se considerou como qualidade na oferta dos cursos investigados, que a síntese resultante mostrou-se tão imprecisa quanto os pseudocritérios encontrados no Sinaes. No seu conjunto, os critérios de qualidade evidenciados não se reportaram aos princípios orientadores da política de formação docente, àqueles verbalizados (ou desejados) pelos coordenadores de curso, seja em função de (in)definições presentes nas DCN da licenciatura de pedagogia, seja pelas imprecisões que permearam os critérios de qualidade do Sinaes. Nesse sentido, a despeito dos princípios presentes no texto da política de formação docente e daqueles idealmente declarados pelos coordenadores de cursos do Parfor, pareceu que, na dinâmica dos cursos, tal concepção não se materializou, efetivamente, como significado da ação deles.

Assim, foi possível considerar a existência de um processo dialético de construção/reconstrução do significado de qualidade, o qual refutou uma visão linear e unidirecional entre a concepção de qualidade e a sua efetivação na realidade empírica. Os dados empíricos corroboraram a perspectiva teórica considerada nesta pesquisa de que são os critérios de qualidade, ao operacionalizar ações reais, que terminam por definir o efetivo significado do termo. Tal entendimento, no entanto, não negou a existência de ideia ou concepção abstrata de qualidade que agregue grupos de interesse em torno de si, tampouco que esta seja apresentada como ponto de partida para a materialização da qualidade desejada na realidade. Os achados apenas alertaram para o fato de esse caminho pode não ser linear. Eles sugeriram que a concepção de qualidade depende do contexto em que ela se faz. A 
simples presença dessas ideias ou ideais pareceu não garantir, por si só, a sua repercussão tal e qual desejada na realidade. 


\section{CONSIDERAÇÕES FINAIS}

Esta pesquisa investigou a relação estabelecida entre os critérios de qualidade presentes na oferta de licenciaturas em pedagogia do Parfor e aqueles utilizados pelo Sinaes para avaliar os cursos de pedagoga em geral. Ao longo da investigação discutiram-se as possibilidades de entendimento e configurações de políticas públicas, bem como sua articulação com os conceitos de Estado e sociedade civil. Para tanto, as políticas públicas foram entendidas, não só por meio de documentos legais, ações coordenadas ou previsão de recursos financeiros nos orçamentos públicos, mas também pelas não ações de governos, moldadas pelos embates entre os atores afetados por elas. Dessa forma, foi possível associar a relação investigada ao padrão de qualidade emanado como política pública, de fato, voltada à adequada formação de professores da educação infantil e dos anos iniciais do ensino fundamental.

As discussões teórico-empíricas que apontaram como pressuposto a existência dessa política foram ratificadas pelos dados analisados. Esses dados evidenciaram que disputas em torno das competências da Capes e do seu CTC-EB na condução das ações de formação inicial de docentes da educação básica vincularam o padrão de qualidade previsto como princípio no Parfor aos critérios de qualidade do Sinaes. No entanto, os arranjos necessários à expansão da oferta de cursos de formação inicial pelo Parfor, aliados aos limites formais da abrangência do Sinaes - circunscrita ao Sistema Federal de Ensino Superior -, não permitiram que esse sistema avaliativo respondesse sozinho pela qualidade dos cursos em questão. Como resultado, observou-se que os critérios presentes nas avaliações do Sinaes, vis-à-vis aqueles efetivamente utilizados pelo Parfor para os cursos presenciais de pedagogia manifestam explicitamente uma relação de ambiguidade, difundindo, de forma latente, um padrão de qualidade impreciso para a formação inicial de professores da educação infantil e dos anos iniciais do ensino fundamental.

Como foi possível constatar, da parte do Sinaes, a qualidade garantida para os cursos de pedagogia baseou-se em pseudocritérios. Por um lado, não foi capaz de revelar os perfis de qualidade desses cursos em relação aos cinco níveis previstos na sua escala de medida, nem a ideia do que se espera de um bom curso de pedagogia no Brasil. Adicionalmente, não foi amplamente reconhecido como o padrão de qualidade a ser seguido, como denotou o baixo uso de alguns dos seus resultados entre os cursos de graduação em geral (RODRIGUES; PEIXOTO, 2009; OLIVEIRA et al., 2013) e de pedagogia do Parfor em específico (discutido na seção 4.2 desta tese). Completando esse quadro, os dados analisados na seção 3.2 
evidenciaram que o Sinaes também não foi capaz de garantir, no caso da pedagogia, coesão interna entre dois dos seus principais instrumentos de avaliação de curso: as visitas avaliativas e o CPC. Ante as limitações encontradas nos critérios estabelecidos pelo sistema avaliativo e a baixa afiliação dos cursos de pedagogia a eles, os dados apontaram para falta de clareza sobre o que, em essência, é um curso de pedagogia com qualidade para o Sinaes.

No que se referiu à qualidade refletida na dinâmica dos cursos de pedagogia do Parfor, identificou-se uma diversidade de propostas de organização desses cursos, sem que fosse possível caracterizar um padrão de qualidade compartilhado por todos Adicionalmente, três (in)definições localizadas nas DCN do curso em questão pareceram contribuir, ao lado das limitações já apontadas sobre o Sinaes, para tal diversidade.

A primeira referiu-se ao perfil do pedagogo. Na aprovação desse documento legal, aparentemente, havia o entendimento de que o curso de pedagogia contemplaria, em essência, a docência na educação infantil e nos anos iniciais do ensino fundamental, atrelada aos conteúdos relativos à gestão de espaços escolares, não escolares e de sistemas educacionais. Porém, as DCN da licenciatura em pedagogia não pareceram ter se mostrado capazes de garantir que conteúdos ligados à formação do especialista em educação fossem igualmente contemplados no processo de formação pedagogo pelo Parfor, dentro do sentido ampliado de docência trazido por ela. Nesse sentido, considerando as especificidades do plano de formação, uma parcela significativa dos cursos enfatizou apenas o eixo de conteúdos, práticas e demais componentes curriculares diretamente afetos à regência de classe, sem que se pudesse estabelecer ao certo o que o Parfor, no seu conjunto, entendeu como padrão de qualidade relativo ao perfil dos pedagogos formados.

A segunda (in)definição presente nas DCN do curso referiu-se às atividades complementares. Legalmente, essas atividades foram definidas como monitoria, iniciação científica, trabalho de conclusão de cursos e atividades de extensão, assumindo um papel de aprofundamento de estudos em temas como educação especial ou de jovens e adultos, entre outras. Porém, numa espécie de ciclo de confusões em função de definições pouco precisas sobre o que a norma chamou de "atividades teórico-práticas" e "práticas de docência e gestão educacional", as atividades complementares passaram a ser entendidas nos cursos presenciais de pedagogia do Parfor como: (1) atividades teóricas (fichamentos, resenhas, etc.); (2) oportunidade de aprimoramento em conteúdos básicos (produção de texto, microinformática, leitura e interpretação, etc.); (3) componente prático das disciplinas teóricas; ou até mesmo (4) da forma que fora originalmente declarado nas diretrizes do curso (monitoria, iniciação científica, trabalho de conclusão de cursos e atividades de extensão). 
A terceira (in)definição referiu-se ao estágio obrigatório. O vácuo da norma em torno de balizamentos para o desenvolvimento dessa prática formativa permitiu arranjos dos mais variados entre os cursos do Parfor. Em apenas alguns casos de cursos do Parfor os estágios efetivamente se configuraram como espaço para experienciar o exercício profissional em pelo menos um dos campos de atuação do pedagogo.

Em virtude dos limites do Sinaes, da diversidade de propostas de organização dos cursos de Pedagogia do Parfor e das indefinições das DCN, identificou-se pouca clareza no que essas políticas assumem, no seu conjunto, como qualidade para a formação de professores da educação infantil e dos anos iniciais do ensino fundamental. Conforme sugeriram as análises teóricas e empíricas realizadas, no seu conjunto, essas políticas vêm orientando, pela inércia, a formação de professores da educação infantil e dos anos iniciais do ensino fundamental, sem apontar os parâmetros que devem balizar o significado de um bom curso nessa área.

No que se refere à concepção de qualidade por trás do padrão encontrado, os dados evidenciam uma definição para ela, mesmo que de forma relativizada. Legalmente, a política de formação docente (BRASIL, 2009a) estabeleceu como concepção de qualidade para os cursos ofertados no âmbito do Parfor, a articulação entre o conhecimento científico organizado e os desafios inerentes ao contexto profissional do professor-aprendiz, com vistas a sua atuação criticamente transformadora na educação básica. Essa concepção foi ratificada pelos coordenadores de cursos de pedagogia do Parfor, conforme dados analisados na subseção 4.2.1, que corroboraram essa concepção de qualidade como o domínio de conhecimentos teóricos e práticos pelos pedagogos em formação, voltados à emancipação dos sujeitos e ao desenvolvimento econômico e social da nação. Porém, os critérios de qualidade presentes na realidade dos cursos demonstraram que o aludido domínio de conhecimentos se materializou tanto na perspectiva do exercício do magistério em turmas da educação infantil e dos anos iniciais do ensino fundamental quanto na perspectiva de docência ampliada, discutida por Aguiar et al. (2006). ${ }^{75}$ Não bastasse o desdobramento basilar dessa diferença de entendimento sobre a docência, as próprias imprecisões sobre a configuração das práticas do curso, aí incluídos os estágios, permitiram dialetizar o real papel da concepção de qualidade destacada pela política de formação docente. Aparentemente, a falta de critérios de qualidade claros vem dificultando que tal concepção se materialize na realidade concreta.

\footnotetext{
${ }^{75}$ As DCN do curso, mesmo elaboradas sobre a perspectiva da docência ampliada, não vedaram a possibilidade de que a docência como exercício profissional em sala de aula organizasse os cursos, mantendo, ambiguamente, a convivência de ambos os sentidos.
} 
No delineamento metodológico da pesquisa, optou-se pela abordagem qualitativa para uma interpretação mais ampla do objeto estudado, concordando-se com Drenth (1984) de que tal abordagem seria capaz de gerar descrições mais detalhadas da realidade empírica, bem como o desenvolvimento dos conceitos e ideias buscados. Por outro lado, se reconheceu que a abordagem qualitativa não está isenta de buscar uma verdade pré-existente nos dados - e por isso mesmo absoluta e descontextualizada. Para minimizar tais limitações, buscou-se nos procedimentos operatórios do hiperempirismo dialético analisar a realidade emergida dos dados como produto da ação humana, e, nesse sentido, livre de ser uma determinação total e definitiva.

Para que tal aproximação entre as bases epistemológicas da pesquisa e o caminho metodológico escolhido pudesse ser viabilizada, assumiu-se o entendimento de Minayo (2013) de que a hermenêutica permitiria correspondência entre a dialética, como ideia, e os instrumentos operativos de pesquisa como realidade concreta. Conforme ressaltou a autora, essa técnica de tratamento do material qualitativo trabalha com a comunicação humana pressupondo que nem tudo na vida social é transparente e inteligível. Para ela, as palavras comunicam mais do que a intenção imediata de quem as emite, exigindo do pesquisador uma permanente aproximação da realidade histórica, que contextualiza e fundamenta a compreensão com vistas a uma aproximação do fato concreto, ou repercussões da realidade, e não apenas daquilo que foi declarado no texto.

Contudo, mesmo diante desses cuidados, não foi possível negar que a abordagem qualitativa trouxe, em si mesma, limites ao resultado que evidencia. Conforme seguiu esclarecendo Minayo (2013), existem múltiplas possibilidades de interpretação de uma realidade, as quais sinalizam que a sua compreensão não é um processo mecânico. Para a autora, "a leitura de qualquer realidade constitui um exercício reflexivo sobre a liberdade humana" (MINAYO, 2013, p. 331). Por isso, não se pôde afastar o risco de que algum aspecto presente na realidade tivesse sido omitido nas análises ou se mostrado mais evidente do que os dados permitiram assumir.

No entanto, Minayo (2013) reforçou que a hermenêutica visa complementarmente: i) esclarecer o contexto dos diferentes atores e das propostas que produzem; ii) identificar a racionalidade existente na linguagem que se utiliza como veículo para estabelecer a comunicação; iii) colocar os fatos no contexto dos atores; iv) julgar e tomar posições sobre o que houve; e iv) produzir um relato de forma que os diferentes atores se sintam contemplados. Nesse sentido, no caso deste trabalho, tais objetivos metodológicos terminaram por se reverter, respectivamente, na identificação de diferentes instâncias e seus interesses em torno 
da Política de Qualidade; na identificação de fóruns institucionalizados para a comunicação desses interesses; no contexto de embates entre grupos de interesses, comunidades epistêmicas, políticos e burocratas diretamente afetados pela Política de Qualidade; e na posição, relatada ao longo deste trabalho, que os embates, ações e omissões que concretizaram a Política de Qualidade favoreceram uma relação de ambiguidade entre os critérios de qualidade do Parfor e do Sinaes para cursos de pedagogia, resultando em balizamentos imprecisos sobre o que configura um bom curso para a formação inicial de professores da educação infantil e dos anos iniciais do ensino fundamental.

Ademais, considerando que tal ambiguidade hermeneuticamente identificada nos dados se constitui como uma categoria metodológica carregada de sentido, foi preciso tecer, ainda, comentários a respeito de suas implicações para a política em análise. Como bem lembrou Gurvitch (1987), o movimento do real provocado pelas ambiguidades pode tanto estruturar quanto desequilibrar um sistema. No caso da Política de Qualidade, a ambiguidade identificada entre os critérios de qualidade do Parfor e do Sinaes, mediados pelas DCN da licenciatura em pedagogia, foi entendida como base de impulsão para os seus próximos movimentos.

Nesse sentido, reconhecendo que os sistemas estruturados por meio de ações humanas e suas respectivas reações estão em constante processo de mudança, foi possível sugerir algumas reflexões que poderiam ajudar a tornar menos impreciso o padrão de qualidade para a formação de professores da educação infantil e dos anos iniciais do ensino fundamental, a saber:

i. Sob a perspectiva do Parfor - reflexões sobre os conteúdos considerados imprescindíveis ao conceito de docência trazido pelas DCN da licenciatura em pedagogia, balizando os desdobramentos da base docente nos currículos dos cursos oferecidos sob sua chancela. A perspectiva aventada por Scheibe e Aguiar (1999) de que o núcleo de estudos básicos, associada a parte diversificada ou de aprofundamento, por si só, organizaria a estrutura curricular do curso em questão não foi encontrada no contexto da Política de Qualidade. Assim, a perspectiva de igualdade no trato dos conteúdos relativos às ciências da educação, ao contexto não escolar e aqueles relacionados ao contexto da educação básica, apenas deslocou a dicotomia então estabelecida entre o especialista em educação e o professor, para a dicotomia entre o pedagogo-generalista (com formação menos aprofundada nas didáticas e nos conteúdos a serem ensinados na educação básica, mas que, em contrapartida, pôde construir conhecimentos sobre gestão de espaços escolares e 
não escolares) e o pedagogo-professor (que se aprofundou nos conteúdos da educação básica e suas didáticas, mas sem ter oportunidade de exercitar, como, por exemplo, nos estágios, os tópicos afetos ao trabalho de especialista em educação). No contraponto entre uma dimensão e outra da organização dos conteúdos curriculares dos cursos de pedagogia oferecidos pelo Parfor, haveria a oportunidade de o Programa articular sua oferta à organização da formação docente, incorporando de forma sistematizada os estudos pósgraduados, numa perspectiva de formação continuada. Além disso, existiria espaço legal para que o Parfor estruturasse um balizamento sobre as características dos estágios nos seus cursos, as áreas temáticas para sua ocorrência, bem como sua relação com as demais práticas previstas para o curso. No conjunto dessas reflexões, seria possível ainda ao Parfor oferecer balizamentos aos seus cursos sobre a necessidade de superação de deficiências na formação básica do aluno, minimizando as disputas desse tempo formativo com aquele necessário ao aprofundamento profissional em educação indígena, educação especial, educação de jovens e adultos, etc. Por fim, seria necessário o reconhecimento dos limites da contribuição do Sinaes no processo de avaliação da qualidade das turmas do Parfor, quando organizadas por meio de projeto pedagógico e corpo docente diferenciado das demais turmas do curso.

ii. Sob a perspectiva do Sinaes - reflexões sobre a pertinência em se manter o Enade da pedagogia centrado naqueles conteúdos classificados pelo próprio Exame como de formação geral, os quais não adentraram em temas diretamente vinculados à profissionalidade do pedagogo (conteúdos a serem ministrados na educação básica e suas didáticas, bem como aqueles ligados à gestão de espaços escolares e não escolares). Adicionalmente, haveria espaços para uma reflexão mais aprofundada sobre indicadores e parâmetros de qualidade dos cursos tanto no instrumento de avaliação in loco quanto nos indicadores que geram o CPC, os quais precisariam contemplar, ainda, um modelo de legitimação política pela comunidade universitária.

Como se percebeu, tais sugestões de reflexão se restringiram propositadamente a uma perspectiva de organização interna do Parfor e do Sinaes, respectivamente, no âmbito da Capes e do Inep. Nesse caso, visualizou-se que a definição de diretrizes acadêmicas pelo Parfor para os seus cursos e o aprofundamento dos ajustes nos instrumentos avaliativos do Sinaes já seriam capazes de estabelecer de forma mais clara o padrão de qualidade da política em foco.

Porém, essa visão restrita do movimento da Política de Qualidade poderia ser ampliada. Para tanto, haveria necessidade de abertura de espaço político interinstitucional 
para reflexões que adentrassem na esfera de competência dos órgãos do MEC. Nesse contexto, um importante ponto seria a articulação das ações do Inep e da Capes, bem como do CNE, da Conaes e do CTC-EB, em torno da qualidade da educação superior, de uma forma geral, e da qualidade da formação inicial de professores, de forma específica. Observou-se neste trabalho que a interpenetração de competência entre os órgãos públicos citados terminou afastando processos naturalmente relacionados. De um lado, a educação superior foi separada entre a graduação e a pós-graduação quando da realização dos processos avaliativos de sua qualidade. Do outro, a política de formação docente foi dividida entre as ações avaliativas de fomento aos cursos de formação e a avaliação da qualidade dos cursos propriamente dita, desarticulando a perspectiva de construção de um sistema nacional de formação de professores, bem como o estabelecimento de diretrizes de longo prazo para a formação inicial e continuada dos profissionais do magistério da educação básica. Considerando ser necessária a construção de pontes para a integração desses referidos processos que estão sob a coordenação geral do MEC, identificaram-se três aspectos nos quais poderiam ocorrer a aproximações entre eles.

$\mathrm{O}$ primeiro refere-se às visitas avaliativas. A despeito das críticas ao processo de avaliação conduzido pela Capes, presente em autores como Horta e Moraes (2005) e Sguissardi (2006), há que se destacar que, diferentemente do que vem ocorrendo no Sinaes, na avaliação da pós-graduação os instrumentos da visita servem apenas indiretamente ao processo de avaliação. No caso da pós-graduação, a experiência vivenciada no cotidiano da Capes permitiu afirmar que as visitas vêm sendo utilizadas, em geral, nos processos de acompanhamento anuais, em auditoria ou conferência in loco de aspectos pouco esclarecidos nos relatórios preenchidos anualmente pelos cursos de pós-graduação. As visitas também têm tido um papel de suporte e orientação aos cursos, quando por eles solicitados ou a partir de indicação de comissão de área de avaliação. Em alguns casos, as visitas e os relatórios delas decorrentes foram utilizados para subsidiar decisões das comissões de área durante as avaliações trienais, mas o conceito final não foi definido por eles. Nesse sentido, o conceito de avaliação não tende a ficar atrelado à percepção dos especialistas que visitam o curso, diminuindo a possibilidade de contágios e de comprometimento da lisura do processo sob a perspectiva do avaliador visitante.

Adicionalmente, o processo de avaliação da pós-graduação tem permitido contrabalançar o tempo e os custos envolvidos com as visitas, restringindo sua utilização a casos identificados qualitativamente como necessários (a partir da análise das áreas, e não por meio de cortes gerados automaticamente por indicadores de qualidade abstratos e pouco 
significativos), ao tempo em que vem garantindo isonomia de procedimentos avaliativos entre os cursos, diferentemente do que vem ocorrendo com o Sinaes, quando parte dos cursos tem suas notas geradas por meio de visitas e parte não. Assim, o modelo de visitas utilizado na avaliação da pós-graduação, além de contribuir para modelar a subjetividade das avaliações in loco, pareceu mostrar-se útil também para resolver a questão logística de se basear um processo avaliativo do porte e abrangência do Sinaes a partir de visitas a cursos e instituições espalhados por todo território nacional.

O segundo aspecto foi localizado no tratamento dado aos indicadores de qualidade e sua relação com as notas dos cursos. Essa diferença tem sido bastante clara na avaliação da pós-graduação, ajudando na estruturação de diagnósticos para a tomada de decisões sobre os cursos e (por que não dizer) pelos cursos. A Avaliação da Capes faz uso dos Cadernos de Indicadores ${ }^{76}$ e das Planilhas Específicas, ${ }^{77}$ material que traz os indicadores de qualidade dos programas de pós-graduação para subsidiar os avaliadores no preenchimento das fichas individuais de avaliação de cada um dos programas de pós-graduação. Nesse caso, os indicadores de qualidade orientam a definição das notas dos itens e quesitos avaliados, gerando um conceito final de avaliação e, ao mesmo tempo, um relatório detalhado sobre pontos fortes e fracos do curso. Como resultado, tal relatório ou Ficha de Avaliação, como é denominado, vem permitindo tanto o processo de regulação nacional ("nota" do curso) quanto os subsídios aos processos microrregulatórios de gestão da qualidade, conforme necessidade, possibilidade, ponderações e decisões das próprias instituições.

Já no caso do Sinaes, indicadores de qualidade e nota de avaliação se confundem, sem que seja realizada uma análise dos avaliadores sobre o que as medidas apuradas indicam para o curso ou para a área de conhecimento da qual ele faz parte. Com isso, existe certo automatismo que faz indicadores equivalerem a conceitos. Verhine e Dantas (2008) esclarecem que a adoção desse procedimento decorreu de certa utilidade operacional e prática do Inep. Assim, ao utilizar os indicadores de qualidade, o referido órgão não teria mais a necessidade de realizar as avaliações in loco, trocando as visitas dos avaliadores a todas as instituições de educação superior, bem como aquelas destinadas aos cursos de graduação, pelo trabalho fácil e ágil do processamento dos indicadores via computador.

No entanto, comparando os dois processos de avaliação da educação superior existentes no Brasil, pôde-se apontar que, no caso dos cursos de graduação, a utilização em

\footnotetext{
${ }^{76}$ Gerados para cada Programa, visando subsidiar uma análise qualitativa de sua realidade.

${ }^{77}$ Relatório de comparação quantitativa dos cursos, a partir dos indicadores mais importantes para o processo avaliativo.
} 
larga escala dos indicadores de qualidade como conceito de avaliação pareceu levar a uma extrema simplificação e limitação do processo avaliativo, oferecendo pouco subsídio a cursos e instituições para promoverem as mudanças necessárias. Além disso, não tem permitido destacar aspectos que requeiram mais atenção para manter ou ampliar sua qualidade.

A diferença estabelecida pela Avaliação da Capes entre indicadores de qualidade e notas avaliativas vem trazendo algumas vantagens quando comparada ao tratamento unívoco dado pelo Sinaes a esses aspetos: a) todos os cursos de pós-graduação de uma mesma natureza (acadêmico x profissionais) são avaliados pelo mesmo conjunto de indicadores, havendo critérios específicos para cada área de conhecimento; b) as fichas de avaliação são preenchidas de forma qualitativa pelos avaliadores individualmente e, como não poderia deixar de ser, subjetivamente. Porém, a nota de cada item que compõe os quesitos ou dimensões das fichas de avaliação possui um critério previamente definido e divulgado no "Documento de Área". ${ }^{78}$ Além disso, a dimensão mais subjetiva de todas, identificada como "proposta do curso", não impacta a nota aferida, sendo utilizada basicamente como componente formativo; c) os avaliadores, reunidos em um mesmo tempo e espaço, fazem parte de uma Comissão de Área o que permite que troquem experiências e parâmetros de medida para o preenchimento das fichas relativas aos cursos de uma área de conhecimento específica - com isso, os avaliadores podem comparar o resultado de cada um dos cursos no conjunto da área, ajustando e dando contorno mais equitativo à subjetividade inerente ao enquadramento dos indicadores de qualidade apurados na escala de avaliação; e d) o Conselho Técnico Científico da Educação Superior (CTC-ES) da Capes promove um novo balizamento dos conceitos de avaliação produzidos pelas comissões de área, tendo como referência, principalmente, os indicadores de desempenho ou resultado (produção acadêmica e corpo discente), numa tentativa de evitar leniência intra-área, principalmente na avaliação dos cursos identificados na escala de notas como seis e sete.

Dessa forma, a separação do processo de avaliação do processo de visitas, aliada à separação dos indicadores de qualidade das notas avaliativas adotadas na pós-graduação, tem viabilizado a produção de Fichas de Avaliação para todos os cursos, não apenas para aqueles que foram visitados. Tais fichas trazem, além do conceito de avaliação, um diagnóstico que referencia a qualidade do Sistema e pode fortalecer decisões a serem tomadas tanto em âmbito nacional quanto local. Há que se destacar ainda que, em função do número de cursos de

\footnotetext{
78 Texto produzido pela Comissão de Área de Avaliação da Capes, que contempla em linhas gerais um balanço do processo de avaliação e sua relação com o desenvolvimento científico em cada campo do conhecimento considerado. Costumam explicitar os principais desafios e padrões de qualidade considerados como necessários para que se promova o contínuo desenvolvimento de determinada área de avaliação.
} 
graduação, o trabalho desempenhado por comissões de avaliação precisa ser adequadamente suprido de informações devidamente tratadas, evitando-se que o avaliador realize manualmente cálculos para gerar as suas análises, como ocorre com alguma frequência na pós-graduação.

O terceiro ponto de aproximação entre os processos em questão poderia ser buscado na discussão em torno do conceito de docência e da articulação entre as DCN da licenciatura em pedagogia e as DCN para a formação de professores, bem como no seu desdobramento nos procedimentos operacionais de oferta e avaliação de curso de licenciatura. Os dados evidenciaram que essas diretrizes precisariam incorporar uma definição clara do conceito de docência (seja ela ampliada ou não). Além disso, seria indicada a análise sobre a repercussão desse conceito de docência na formação de especialistas em educação e gestores de espaços escolares e não escolares. Na realidade concreta, qualquer professor, inclusive aquele que não possui formação no contexto da docência ampliada, está assumindo encargos de coordenação pedagógica e direção escolar, entre outros, sem a exigência de conhecimentos profissionais especializados. Nesse sentido, refletir, do ponto de vista legal, sobre o conceito de docência e a sua repercussão no cotidiano escolar, nos sistemas educativos e nos espaços não escolares para todas as licenciaturas e não apenas para a pedagogia emergiu como relevante no contexto dos resultados encontrados nesta pesquisa. Adicionalmente, essa discussão poderia permitir, ainda, organizar a formação continuada, não apenas para os cursos de iniciação à docência do Parfor, como também para os demais em operação no Brasil.

Por fim, tornou-se necessário enfatizar a perspectiva trazida pelo hiperempirismo dialético segundo a qual os fenômenos humanos não podem ser considerados como prontos e acabados. Nesse sentido, as reflexões sugeridas não se configuram como caminhos únicos, tampouco permanentes, na busca do equilíbrio da Política de Qualidade aqui estudada. Porém, entendeu-se que tais reflexões podem contribuir com o estabelecimento de padrões mais precisos para a formação de professores da educação infantil e dos anos iniciais do ensino fundamental. 


\section{REFERÊNCIAS}

ABREU JÚNIOR, Nelson de. Sistema(s) de avaliação da educação superior brasileira Cadernos Cedes, Campinas, v. 29, n. 78, p. 257-269, maio/ago. 2009.

AFONSO, Almerindo Janela. Ensaio sobre accountability no ensino superior em Portugal (1976-2013): discursos, formas parcelares e modelo atual. In: SOUSA, José Vieira (Org.). Educação superior: cenários, impasses, propostas. Campinas: Autores Associados, 2013. p. 13-59. (Coleção Políticas Públicas de Educação).

AGUIAR, Márcia Ângela da Silva et al. Diretrizes curriculares do curso de pedagogia no Brasil: disputas de projetos no campo da formação do profissional da educação. Educação \& Sociedade, Campinas, v.27, n. 96, p. 819-842, out. 2006.

.; MELO, Márcia Maria de Oliveira. Pedagogia e as diretrizes curriculares do curso de pedagogia: polêmicas e controvérsias. Revista Linhas Críticas, Brasília, v. 11, n. 20, p. 119138, jan./jun. 2005.

ALVES, Amélia Regina; TAMAYO, Álvaro. Sistema de avaliação do treinamento da Telebrás - SAT. Revista de Administração, São Paulo, v. 28, n. 4, p. 73-80, out./dez. 1993.

ANDRADE, Luciane Sá de. Formação de professores em nível médio na modalidade a distância: a experiência do Proformação. Campinas, S. P. Autores Associados, 2011. 310 p. (Coleção Políticas Públicas de Educação).

ANTUNES, Ricardo. Adeus ao trabalho? Ensaio sobre as metamorfoses e a centralidade do mundo do trabalho. São Paulo: Cortez, Cap. 1, p. 13-38. 1995.

ARAÚJO, Eutalia Aparecida Candido de; ANDRADE, Dalton Francisco de; BORTOLOTTI, Silvana Ligia Vincenzi. Teoria da Resposta ao Item. Revista da Escola de Enfermagem da USP [online], São Paulo, v. 43, número especial, p. 1000-1008, dez. 2009.

ARAÚJO, Viviane Patricia Colloca. A multiculturalidade nas políticas educacionais e a formação de professores: Brasil e Portugal. 2009. 436 p. Tese (Doutorado em Educação) -. Universidade Federal de São Carlos, São Carlos, 2009.

ARGYRIS, Chris; SCHÖN, Donald. Organizational Learning: a theory of action perspective. Reading MA: Addison-Wesley, 1978, 356 p.

AUSTRÁLIA. Ministerial Council for Education, Early Childhood Development and Youth Affairs. (MCEECDYA). Accreditation of initial teacher education programs in Australia: Standards and Procedures. Melbourne, (Updated december 2012), 2011. 24 p. Disponível em: $<$ http://www.aitsl.edu.au/docs/default-source/default-documentlibrary/accreditation_of_initial_teacher_education_file> Acesso em: 23 out. 2013.

Accreditation of initial teacher education programs in Australia: Guide to the accreditation process. Melbourne, 2013. 42 p. Disponível em: 
<http://www.aitsl.edu.au/docs/default-source/initial-teacher-education-

resources/guide_to_the_accreditation_process_file.pdf > Acesso em 23 out. 2013.

BABBIE, Earl. Métodos de pesquisas. Minas Gerais: UFMG, 1995. 519 p.

BANCO de Teses: sistema de consulta a base de dados da Capes sobre teses e dissertações defendidas no Brasil. http://capesdw.capes.gov.br/capesdw/.

BARRETTO, Elba Siqueira de Sá. A avaliação na educação básica entre dois modelos.

Educação \& Sociedade, Campinas, ano XXII, n. 75, p. 48-66, ago. 2001.

BARREYRO, Gladys Beatriz. De exames, rankings e mídia. Avaliação (Campinas), Sorocaba, v. 13, n. 3, p. 863-868, nov. 2008.

.; ROTHEN, José Carlos. "Sinaes” contraditórios: considerações sobre a elaboração e implantação do sistema nacional de avaliação da educação superior Educação \& Sociedade, Campinas, v. 27, n. 96, p. 955-977, out. 2006.

. Para uma história da avaliação da educação superior brasileira: análise dos

documentos do PARU, CNRES, GERES E PAIUB. Avaliação (Campinas), Sorocaba, v. 13, n. 1, p. 131-152, mar. 2008.

BARROSO, João. O Estado, a educação e a regulação das políticas públicas. Educação \& Sociedade, Campinas, v. 26, n. 92, p. 725-751, out. 2005.

. O Estado e a educação: a regulação transnacional, a regulação nacional e a regulação local. In: BARROSO, João (Org.). A regulação das políticas públicas de educação: espaço, dinâmicas e actores. Coimbra: Educa; UI\&DCE, 2006, p. 41-70.

BERTOLIN, Julio César Godoy. Avaliação da qualidade do sistema de educação superior brasileiro em tempos de mercantilização - Período 1994-2003. 2007. 282 f. Tese (Doutorado em Educação) - Universidade do Rio Grande do Sul, Porto Alegre, 2007.

BITTENCOURT, Hélio Radke et al. Mudanças nos pesos do CPC e seu impacto nos resultados de avaliação em universidades federais e privadas. Avaliação (Campinas), Sorocaba, SP, v. 15, n. 3, p. 147-166, nov. 2010.

BONNEFOY, Juan Cristóbal; ARMIJO, Marianela. Indicadores de desempeño en el sector público. Chile: Instituto Latinoamericano y del Caribe de Planificación Económica y Social ILPES. Serie Manuales 45. 2005. 106 p.

BOSCHETTI, Ivanete. Avaliação de políticas, programas e projetos sociais. In: CFESS/ABEPSS. Serviço Social: Direitos Sociais e Competências Profissionais. Brasília: CFESS, ABEPSS, 2009. p. 575-593. 


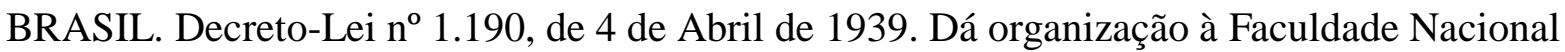
de Filosofia. Diário Oficial da União, Rio de Janeiro, 06 Abr. 1939. Seção 1, p.7929. Disponível em < http://www2.camara.leg.br/ >. Acesso em Acesso em: 16 nov. 2011.

MPV no 150/1990 (MEDIDA PROVISÓRIA), de 15 de março de 1990. Dispõe sobre a organização da Presidência da República e dos Ministérios, e dá outras providências. Diário Oficial [da] República Federativa do Brasil, Brasília, DF, 16 mar. 1990. Disponível em: < http://legislacao.planalto.gov.br/legisla/legislacao.nsf/8b6939f8b38f377 a03256ca200686171/65c50d34eaaad557032569fa0067c5b0?OpenDocument>. Acesso em: 16 jun. 2010. (Convertida na Lei ${ }^{\circ} 8.028$, de 12 de abril de 1990).

Lei ${ }^{\circ}$ 8.405, de 9 de janeiro de 1992. Autoriza o Poder Executivo a instituir como fundação pública a Coordenação de Aperfeiçoamento de Pessoal de Nível Superior (Capes) e dá outras providências. Diário Oficial [da] República Federativa do Brasil, Brasília, DF, 10 jan. 1992. Disponível em: <http://www.planalto.gov.br >. Acesso em: 16 jun. 2010.

Lei $\mathrm{n}^{\circ}$ 9.131, de 24 de novembro de 1995. Altera dispositivos da Lei n. ${ }^{\circ} 4.024$, de 20 de dezembro de 1961, e dá outras providências. Diário Oficial [da] República Federativa do Brasil, Brasília, DF, 25 nov. 1995. Disponível em: <http://www.planalto.gov.br>. Acesso em: 20 fev. 2011.

Lei n ${ }^{\circ}$ 9.394, de 20 de dezembro de 1996. Institui as diretrizes e bases da educação nacional. Diário Oficial [da] República Federativa do Brasil, Brasília, DF, 20 dez. 1996. Disponível em <http://www.planalto.gov.br >. Acesso em: 16 jun. 2012.

Lei n ${ }^{\circ} \mathbf{1 0 . 8 6 1}$, de 14 de abril de 2004. Institui o Sistema Nacional de Avaliação da Educação Superior - Sinaes e dá outras providências. Diário Oficial [da] República Federativa do Brasil, Brasília, DF, 15 abr. 2004a. Disponível em: <http://www.planalto.gov.br >. Acesso em: 20 maio. 2012.

Lei $\mathrm{n}^{\mathrm{o}}$ 11.502, de 11 de julho de 2007. Modifica as competências e a estrutura organizacional da fundação Coordenação de Aperfeiçoamento de Pessoal de Nível Superior CAPES, de que trata a Lei n ${ }^{\circ} 8.405$, de 9 de janeiro de 1992. Diário Oficial [da] República Federativa do Brasil, Brasília, DF, 12 jul. 2007a. Disponível em: <http://www.planalto.gov.br>. Acesso em: 7 dez. 2011.

Decreto no 3.276, de 6 de dezembro de 1999. Dispõe sobre a formação em nível superior de professores para atuar na educação básica, e dá outras providências. Diário Oficial [da] República Federativa do Brasil, Brasília, DF, 7 dez. 1999a. Disponível em: <http://www.planalto.gov.br >. Acesso em: 20 mar. 2012.

Decreto $n^{\circ} 3.554$, de 7 de agosto de 2000. Dá nova redação ao $\S 2 .^{\circ}$ do art. $3 .^{\circ}$ do Decreto no 3.276, de 6 de dezembro de 1999, que dispõe sobre a formação em nível superior de professores para atuar na educação básica, e dá outras providências. Diário Oficial [da] República Federativa do Brasil, Brasília, DF, 8 ago. 2000. Disponível em: <http://www.planalto.gov.br >. Acesso em: 20 mar. 2012. 
Decreto $\mathrm{n}^{\mathbf{0}} \mathbf{5 . 7 7 3}$, de 9 de maio de 2006. Dispõe sobre o exercício das funções de regulação, supervisão e avaliação de instituições de educação superior e cursos superiores de graduação e seqüenciais no sistema federal de ensino. Diário Oficial [da] República Federativa do Brasil, Brasília, DF, 10 maio. 2006a. Disponível em:

<http://www.planalto.gov.br >. Acesso em: 16 jun. 2012.

Decreto $n^{\circ}$ 6.094, de 24 de abril de 2007. Dispõe sobre a implementação do Plano de Metas Compromisso Todos pela Educação (Compromisso). Diário Oficial [da] República Federativa do Brasil, Brasília, DF, 25 abr. 2007b. Disponível em:

<http://www.planalto.gov.br >. Acesso em: 16 jun. 2012.

Decreto $^{\circ}$ 6.316, de 20 de dezembro de 2007. Aprova o Estatuto e o quadro demonstrativo dos cargos em comissão da Coordenação de Aperfeiçoamento de Pessoal de Nível Superior - Capes e dá outras providências (Revogado pelo Decreto ${ }^{\circ}$ 7.692/2012). Diário Oficial [da] República Federativa do Brasil, Brasília, DF, 21 dez. 2007c. Disponível em: <http://www.planalto.gov.br >. Acesso em: 19 jul. 2013.

Decreto ${ }^{\circ}$ 6.755, de 29 de janeiro de 2009. Institui a Política Nacional de Formação de Profissionais do Magistério da Educação Básica, disciplina a atuação da CAPES no fomento a programas de formação inicial e continuada e dá outras providências. Diário Oficial [da] República Federativa do Brasil, Brasília, DF, 30 jan. 2009a. Disponível em: <http://www.planalto.gov.br >. Acesso em: 16 jun. 2012.

Decreto $\mathrm{n}^{\circ} 7.219$, de 24 de junho de 2010. Dispõe sobre o Programa Institucional de Bolsa de Iniciação à Docência - PIBID e dá outras providências. Diário Oficial [da] República Federativa do Brasil, Brasília, DF, 25 jun. 2010. Disponível em: <http://www.planalto.gov.br >. Acesso em: 16 nov. 2011.

Decreto $\mathrm{n}^{\circ}$ 7.692, de 2 de março de 2012. Aprova o Estatuto e o Quadro Demonstrativo dos Cargos em Comissão da Coordenação de Aperfeiçoamento de Pessoal de Nível Superior - CAPES, e remaneja cargos em comissão. Diário Oficial [da] República Federativa do Brasil, Brasília, DF, 3 mar. 2012. Disponível em:

<http://www.planalto.gov.br >. Acesso em: 5 jan. 2014.

Ministério da Educação. Portaria Normativa no 40, de 12 de dezembro de 2007. Institui o e-MEC, sistema eletrônico de fluxo de trabalho e gerenciamento de informações relativas aos processos de regulação, avaliação e supervisão da educação superior no sistema federal de educação, e o Cadastro e-MEC de Instituições e Cursos Superiores e consolida disposições sobre indicadores de qualidade, banco de avaliadores (Basis) e o Exame Nacional de Desempenho de Estudantes (Enade) e outras disposições. Diário Oficial [da] República Federativa do Brasil, Brasília, DF, 13 dez. 2007d (republicada de forma consolidada em 29 dez. 2010). Disponível em: 〈http:// meclegis.mec.gov.br >. Acesso em: 20 maio. 2012.

Ministério da Educação. Portaria Normativa ${ }^{\circ}$ 4, de 5 de agosto de 2008.

Regulamenta a aplicação do conceito preliminar de cursos superiores - CPC, para fins dos processos de renovação de reconhecimento respectivos, no âmbito do ciclo avaliativo do Sinaes instaurado pela Portaria Normativa n 40, de 2007. Diário Oficial [da] República Federativa do Brasil, Brasília, DF, 06 ago. 2008. Disponível em: <http:// meclegis.mec.gov.br >. Acesso em: 20 maio. 2012. 
Ministério da Educação. Portaria Normativa $n^{\circ}$ 9, de 30 de junho de 2009. Institui o Plano Nacional de Formação dos Professores da Educação Básica no âmbito do Ministério da Educação. Diário Oficial [da] República Federativa do Brasil, Brasília, DF, 01 jul. 2009b. Disponível em: <http:// meclegis.mec.gov.br >. Acesso em: 16 jun. 2010.

Ministério da Educação. Portaria $n^{0} 883$, de 16 de setembro de 2009. Estabelece as diretrizes nacionais para o funcionamento dos Fóruns Estaduais Permanentes de Apoio à Formação Docente, criados pelo Decreto nº 6.755, de 29 de Janeiro de 2009. Diário Oficial [da] República Federativa do Brasil, Brasília, DF, 17 set. 2009c. Disponível em: <http://meclegis.mec.gov.br>. Acesso em: 16 jun. 2012.

Ministério da Educação. Portaria normativa no 3, de 2 de março de 2011. Institui a Prova Nacional de Concurso para o Ingresso na Carreira Docente. Diário Oficial da União. Brasília, DF, 03 mar. 2011a. Seção 1, p. 9.

Ministério da Educação. Portaria n ${ }^{\circ}$ 1.087, de 10 de agosto de 2011. Institui o Comitê Gestor da Política Nacional de Formação Inicial e Continuada de Profissionais da Educação Básica e define suas diretrizes gerais. Diário Oficial da União. Brasília, DF, 11 ago. 2011b. Seção 1, p. 20.

Ministério da Educação. Coordenação de Aperfeiçoamento de Pessoal de Nível Superior. Portaria $\mathrm{n}^{\circ} 1$, de 4 de janeiro de 2011. Prorroga mandato dos membros do Conselho Técnico-Científico da Educação Básica da Capes (CTC-EB). Diário Oficial da União. Brasília, DF, 07 jan. 2011c. Seção 1, p. 12.

Ministério da Educação. Coordenação de Aperfeiçoamento de Pessoal de Nível Superior. Portaria $\mathrm{n}^{\circ}$ 203, de 18 de outubro de 2011. Designa membros do Conselho TécnicoCientífico da Educação Básica da CAPES (CTC-EB). Diário Oficial da União. Brasília, DF, 20 out. 2011d. Seção 1, p. 20.

Ministério da Educação. Instituto Anísio Teixeira. Portaria Inep no 225, de 26 de julho de 2011. Brasília, DF, 27 jul. 2011e. Disponível em: <http://download.inep.gov.br/educacao_superior/enade/legislacao/2011/diretrizes/ diretrizes_pedagogia_n_225.pdf>. Acesso em: 12 dez. 2012.

Ministério da Educação. Conselho Nacional de Educação. Resolução CNE/CP n ${ }^{\circ}$, de 30 de setembro de 1999, que institui Diretrizes Gerais para os Institutos Superiores de Educação. Diário Oficial [da] República Federativa do Brasil, Brasília, DF, 7 out. 1999b. Disponível em: <http:// meclegis.mec.gov.br >. Acesso em 8 out. 2011.

Ministério da Educação. Conselho Nacional de Educação. Resolução CNE/CP n 1, de 18 de fevereiro de 2002, que institui Diretrizes Curriculares Nacionais para a Formação de Professores da Educação Básica, em nível superior, curso de licenciatura, de graduação plena. Brasília, DF, 19 fev. 2002. Disponível em: <http:// meclegis.mec.gov.br >. Acesso em 8 out. 2011.

Ministério da Educação. Conselho Nacional de Educação. Resolução CNE/CP no 2, de 27 de agosto de 2004, que adia o prazo previsto no art. 15 da Resolução CNE/CP 1/2002, 
que institui Diretrizes Curriculares Nacionais para a Formação de Professores da Educação Básica, em nível superior, curso de licenciatura, de graduação. Brasília, DF, 28 ago. 2004b. Disponível em: <http:// meclegis.mec.gov.br >. Acesso em 8 out. 2011.

Ministério da Educação. Conselho Nacional de Educação. Resolução CNE/CP no 1, de 17 de novembro de 2005, que altera a Resolução CNE/CP n ${ }^{\circ}$ 1/2002, que institui Diretrizes Curriculares Nacionais para a Formação de Professores da Educação Básica, em nível superior, curso de Licenciatura de graduação plena. Brasília, DF, 18 nov. 2005. Disponível em: <http:// meclegis.mec.gov.br >. Acesso em 8 out. 2011.

Ministério da Educação. Conselho Nacional de Educação. Resolução CNE/CP no 1, de 15 de maio de 2006, que institui Diretrizes Curriculares Nacionais para o Curso de Graduação em pedagogia, licenciatura. Brasília, DF, 16 maio. 2006b. Disponível em: <http:// meclegis.mec.gov.br >. Acesso em 8 out. 2011.

Ministério da Educação. Conselho Nacional de Educação. Parecer CNE/CP no 9/2001, de 9 de maio de 2001. Diretrizes Curriculares Nacionais para a Formação de Professores da Educação Básica, em nível superior, curso de licenciatura, de graduação plena. Brasília, DF, 10 maio. 2001. Disponível em: < http://portal.mec.gov.br/cne /arquivos/pdf/009.pdf>. Acesso em 3 jun. 2014.

Ministério da Educação. Conselho Nacional de Educação. Parecer CNE/CES no 121/2007, de 10 de maio de 2007. Reexame do Parecer $n^{\circ} 37 / 2007$, que dispõe sobre o art. 52 da Lei $n^{\circ}$. 9.394/1996 e institui orientações para o seu atendimento, tendo em vista consulta do CRUB e da SESu/MEC. Brasília, DF, 11 maio. 2007e. Disponível em: < http://portal.mec.gov.br/cne/arquivos/pdf/2007/ pces121_07.pdf>. Acesso em 3 jun. 2014.

Ministério da Educação. Secretaria Executiva. Comitê Gestor da Política Nacional de Formação Inicial e Continuada de Profissionais da Educação Básica. Resolução no ${ }^{1}$, de 17 de agosto de 2011. Diário Oficial da União. Brasília, DF, 20 set. 2011f. Seção 1, p. 15.

Ministério da Administração e Reforma do Estado. Programa de Modernização do Poder Executivo Federal Brasileiro. Brasília: MARE, 1998. 70p. (Cadernos MARE da Reforma do Estado, 16). Disponível em: <http://www.planejamento.gov.br/secretarias/upload/ Arquivos/publicacao/seges/PUB_Seges_Mare_caderno16.PDF>. Acesso em: 12 dez. 2012.

BRÍGIDO, Raimundo Vossio. Certificação e normalização de competências: origens, conceitos e práticas. Boletim Técnico do SENAC, Rio de Janeiro, v. 27, n. 1, p. 3-15, jan./abr. 2001.

BURLAMAQUI, Marco Guilherme Bravo. Avaliação e qualidade na educação superior: tendências na literatura e algumas implicações para o sistema de avaliação brasileiro. Estudos em Avaliação Educacional, São Paulo, v. 19, n. 39, jan./abr. 2008.

CABRITO, Belmiro Gil. Avaliar a qualidade em educação: avaliar o quê? Avaliar como? Avaliar para quê? Cadernos Cedes, Campinas, v. 29, n. 78, p. 178-200, maio/ago. 2009. 
CÁNOVAS, Cecilio Nieto. Gurvitch (1894-1965). Madrid: Ediciones Del Orto.1997, 93 p. (Coleção Biblioteca Filosófica).

CAPES (Fundação Coordenação de Aperfeiçoamento de Pessoal de Nível Superior). Plano Nacional de Formação dos Professores da Educação Básica - Parfor Presencial. Manual Operativo. Brasília, DF, 27 ago.2014. Disponível em < http://www.capes.gov.br/images/ stories/ download/ legislacao/ 2782014-MANUAL-OPERATIVO-PARFOR.pdf. Acesso em: 10 dez. 2014.

CARVAJAL, Alicia L.; VILLARREAL, Ninfa Maricela Villegas. La práctica en la formación inicial de profesores de educación primaria: consideraciones múltiples. In: FLORES, Etelvina Sandoval; BLUM-MARTINEZ, Rebecca; ANDREWS Ian Harold. (Orgs.). Desafíos y posibilidades en la formación de maestros. Una perspectiva desde América del Norte / Etelvina Sandoval Flores. México: UPN, 2009. p. 183-208.

CRUZ NETO, Otávio. O trabalho de Campo como descoberta e criação. In: MINAYO, Maria Cecília de Souza (Orgs.). Pesquisa social: teoria, método e criatividade. 14.ed. Petrópolis: Vozes, 2010. (Capítulos 3).

DELORS, Jacques (Org.). Educação, tesouro a descobrir. Relatório para a Unesco da Comissão Internacional sobre Educação para o século XXI. UNESCO/Edições ASA/Cortez, 1997. 288 p. (Edição brasileira).

DIAS, Rosanne Evangelista; LOPES, Alice Casimiro. Competências na formação de professores no Brasil: o que (não) há de novo. Educação \& Sociedade: Campinas, v. 24, n. 85, dez. 2003, p. 1155-1177.

DIAS SOBRINHO, José. Avaliação da educação superior: avaliação regulação e emancipação. Avaliação (Campinas), Sorocaba, v. 8, n. 2, p. 31-47, mar. 2003.

Acreditação da educação superior. In: SEMINÁRIO INTERNACIONAL DE AVALIAÇÃO DA EDUCAÇÃ̃O SUPERIOR, 1. 2008. Brasília. Anais Eletrônicos... Brasília: MEC, 2008a. Disponível em: <http://portal.mec.gov.br/index.php?option =com_content $\&$ view=article \&id=15305:seminario-internacional-de-avaliacao-da-educacaosuperior-2008\&catid=323:orgaos-vinculados\&Itemid=1075>. Acesso em: 24 maio. 2012.

Qualidade, avaliação: do Sinaes a índices. Avaliação (Campinas), Sorocaba, v. 13, n. 3, p. 817-825, nov. 2008b.

DOURADO, Luiz Fernandes; OLIVEIRA, João Ferreira de. A qualidade da educação: perspectivas e desafios. Cadernos Cedes, Campinas v. 29, n. 78, p. 201-215, maio/ago. 2009.

DRENTH, Pieter Johan Diederik. Research in work and organizational psychology: principles and methods. Handbook of work and organizational psychology. New York: McGrawHill. p. 13-51, 1984. 
DUTRA, Marina Laura. Avaliação de treinamento. Tecnologia Educacional, Rio de Janeiro, v. 13, n. 57, p. 14-26, mar./abr. 1984.

DYE, Thomas. Understanding public police. New Jersey : Pearson, 2012, 14 ed. 384 p.

E-MEC: permite que o cidadão acesse o cadastro de cursos e IES no MEC, bem como informações sobre atos regulatórios, processos e ocorrências no âmbito do Ministério da Educação. http://www.emec.mec.gov.br.

FARIA, Carlos Aurélio Pimenta de. Ideias, conhecimento e políticas públicas: um inventário sucinto das principais vertentes analíticas recentes. Revista Brasileira de Ciências Sociais, São Paulo, v. 18, n. 51, p.21-29, fev.2003.

FLEURY, Maria Tereza Leme; FLEURY, Afonso. Construindo o conceito de competência. Revista de Administração Contemporânea, Rio de Janeiro, v. 5, p. 183-196, 2001. Edição Especial.

FONSECA, Marília. Políticas públicas para a qualidade da educação brasileira: entre o utilitarismo econômico e a responsabilidade social. Cadernos Cedes, Campinas, v. 29, n. 78, p. 153-177, maio/ago. 2009.

. Regulação da educação brasileira e seus efeitos na gestão da educação superior. In: CONGRESSOS IBERO-LUSO-BRASILEIRO DE POLÍTICA E ADMINISTRAÇÃO DA EDUCAÇÃO, I. 2010, Elvas, Portugual; Cáceres e Mérida, Espanha. Anais Eletrônicos... Elvas, Portugual; Cáceres e Mérida, Espanha: Fepae (Portugal)/Feae (Espanha)/Anpae (Brasil)., 2010. Disponível:

<http://www.anpae.org.br/iberolusobrasileiro2010/cdrom/86.pdf>. Acesso em: 13 dez. 2012.

FONTANELLA, Bruno José Barcellos et al. Amostragem em pesquisas qualitativas: proposta de procedimentos para constatar saturação teórica Cadernos de Saúde Pública, Rio de Janeiro, v. 27, n. 2, p. 389-394, fev. 2011.

.; RICAS, Janete; TURATO, Egberto Ribeiro. Amostragem por saturação em pesquisas qualitativas em saúde: contribuições teóricas. Cadernos de Saúde Pública, Rio de Janeiro, v. 24, n. 1, p.17-27, jan. 2008.

FRANCO, Maria Amélia Santoro; LIBÂNEO, José Carlos; PIMENTA, Selma Garrido. Elementos para a formulação de diretrizes curriculares para cursos de pedagogia. Cadernos de Pesquisa, São Paulo, v. 37, n. 130, p. 63-97, jan./abr. 2007.

FREITAS, Katia; CHACON, Fabio ; GIRLING, Robert Henriques. Políticas de educação e formação de educadores: uma relação necessária. Revista FAEEBA, Salvador, v. 21, n. 38, p. 105-113, jul./dez. 2012.

FREIRE, Paulo. Política e educação: ensaios. São Paulo, Cortez, 2001, 5. ed. 57p. 
FREY, Klaus. Políticas públicas: um debate conceitual e reflexões referentes à prática da análise de políticas públicas no Brasil. Planejamento e Políticas Públicas, Brasília, n. 21, p.211-259, jun. 2000.

GADOTTI, Moacir. Concepção dialética da educação: um estudo introdutório. 14. ed. São Paulo: Cortez. 2003. 182p.

GARVIN, David. Competing on the eight dimensions of quality. Harvard Business Review, Boston, v. 65, n. 6, nov./dec. 1987.

GATTI, Bernardete A. Formação de professores para o ensino fundamental: estudo de currículos das licenciaturas em pedagogia, língua portuguesa, matemática e ciências biológicas / Bernardete A. Gatti; Marina Muniz R. Nunes (Orgs.). São Paulo: FCC/DPE, 2009. 158 p. (Coleção Textos FCC, 29)

Formação de professores no Brasil: características e problemas. Educação \& Sociedade, Campinas, v. 31, n. 113, p. 1355-1379, out./dez. 2010.

Documento contendo análises pedagógico-curriculares para os cursos de licenciatura vinculados às áreas de artes, biologia, história, língua portuguesa, matemática e pedagogia no âmbito da UAB e Parfor. Brasília, 2012. 54p. (Produto 2 apresentado à Unesco, referente ao Projeto 914BRZ1001.3 - Capes - Fortalecimento da capacidade institucional com vistas ao incremento da educação básica, como resultado de Consultoria ao referido Projeto)

GIL, Antonio Carlos. Métodos e técnicas de pesquisa social. 5. ed. São Paulo: Atlas, 1999. $306 \mathrm{p}$.

GIROUX, Henry. Os professores como intelectuais: rumo a uma pedagogia crítica da aprendizagem. Porto Alegre: Artes Médicas, 1997. 270 p.

GOOGLE Acadêmico: sistema de pesquisa de artigos acadêmicos. Disponível em: <http://scholar.google.com.br/>. Acesso em: 13 dez. 2012.

GOMES, Paulo. A evolução do conceito de qualidade: dos bens manufacturados aos serviços de informação. Cadernos BAD, Lisboa, n. 2, p. 6-18, 2004.

GRAMSCI, Antonio. Concepção dialética da história. Rio de Janeiro: Civilização Brasileira, 1966, 337 p.

Os intelectuais e a organização da cultura. 4. ed. Rio de Janeiro: Civilização Brasileira, 1982. $241 \mathrm{p}$.

GURVITCH, Georges. Dialética e sociologia. São Paulo: Vértice, 1987. 239 p.

HAAS, Peter. Introduction: epistemic communities and international policy coordination. International Organization, Cambridge, v. 46, n.1, p. 1-35, inverno/1992. 
HARVEY, David. A condição pós-moderna: uma pesquisa sobre a origem da mudança cultural. São Paulo: Loyola, 1992. 349 p.

HARVEY, Lee; GREEN, Diana. Defining quality. Assessment \& Evaluation in Higher Education, London, v. 18, issue 1, p. 9-26, apr. 1993.

; WILLIAMS, James: Fifteen years of quality in higher education. Quality in Higher

Education, London, v. 16, n. 1, p.3-36, apr. 2010.

HIRATA, Helena. Da polarização das qualificações ao modelo de competência. In:

FERRETI, Celso et al. (Orgs.). Novas tecnologias, trabalho e educação: um debate multidisciplinar. Petrópolis: Vozes, 1994. p. 124-138.

HORTA, José Silvério Baía; MORAES, Maria Célia Marcondes de. O sistema Capes de avaliação da pós-graduação: da área de educação à grande área de ciências humanas. Revista Brasileira de Educação. Rio de Janeiro, n. 30, p. 95-116, set./dez. 2005.

HORTALE, Virginia Alonso; MOREIRA, Carlos Otávio F.; KOIFMAN, Lilian. Avaliação da qualidade da formação: contribuição à discussão na área da saúde coletiva. Ciência \& Saúde Coletiva, Rio de Janeiro, v. 9, n. 4, p. 997-1002, 2004.

INEP (Instituto Nacional de Estudos e Pesquisas Educacionais Anísio Teixeira). Sinopse Estatística da Educação Superior 1995. [1996?]. Disponível em: <http://www.inep.gov.br〉. Acesso em: 20 maio. 2012.

. Educação para todos: avaliação da década. Brasília: MEC/Inep, 2000. 210p.

(Síntese do I Seminário Nacional sobre Educação para Todos - Brasília, 10 e 11/6/1999)

.2008_enade_cpc_decomposto_23_05_2011.[2009?a]. Disponível em:

<http://portal.inep.gov.br/planilhas-enade>. Acesso em: 4 ago. 2013.

. Sinopse Estatística do Professor da Educação Básica 2009. [2009?b]. Disponível em: <http://www.inep.gov.br>. Acesso em: 20 maio. 2012.

Instrumento de avaliação de cursos de graduação presencial e a distância. Brasília, fevereiro de 2012a. Disponível em: 〈http://www.inep.gov.br>. Acesso em: 20 maio. 2012.

. Nota Técnica n. ${ }^{\circ}$ 029, de 15 de outubro de 2012b. Disponível em: <http://www.inep.gov.br>. Acesso em: 12 dez. 2012.

. Tabela_Enade_CPC_2011_retificado_08_12_13.[2013].Disponível em: <http://portal.inep.gov.br/planilhas-enade>. Acesso em: 04.ago. 2013.

Sinopse Estatística da Educação Superior 2013.[2014]. Disponível em: <http://www.inep.gov.br>. Acesso em: 20 maio. 2012. 
JANNUZZI, Paulo. Indicadores sociais no Brasil: conceitos, medidas e aplicações. 3 ed. Campinas: Alínea; Campinas: PUC, 2004.

Considerações sobre o uso, mau uso e abuso dos indicadores sociais na formulação e avaliação de políticas públicas municipais. Revista do Serviço Público, Brasília, abr./jun. 2005.

JOBERT, Bruno; MULLER, Pierre. L'Etat en action: politiques publiques et corporatismes. Paris : Presses Universitaires de France, 1987, 238 p.

JURAN, Joseph. How to think about quality. In: JURAN, Joseph; GODFREY, A. Blanton. Jurans quality handbook. 5 ed. New York: McGraw-Hill, 1999. (section two).

LEITÃO, Jaqueline. Clima organizacional na transferência de treinamento. Revista de Administração, São Paulo, v. 31, n. 3, p.53-62, jul./set. 1996.

LIBÂNEO, José Carlos. Diretrizes curriculares da pedagogia: imprecisões teóricas e concepção estreita da formação profissional de educadores. Educação \& Sociedade, Campinas, v. 27, n. 96, Especial, p. 843-876, out. 2006.

Reflexividade e formação de professores: outras oscilações do pensamento pedagógico brasileiro? In: PIMENTA, Selma Garrido; GHEDIN, Evandro (Orgs.). Professor reflexivo no Brasil: gênese e crítica de um conceito. São Paulo: Cortez, 2008. p. 53-79.

LIMA, Suzana Maria; BORGES-ANDRADE, Jairo Eduardo; VIEIRA, Solange Batista. Cursos de curta duração e desempenho em instituições de pesquisa agrícola. Revista de Administração, São Paulo, v. 24, n. 2, p. 36-46, abr./jun. 1989.

LOWI, Theodor. American business, public policy, case studies and political theory. World Politics, v. 16, p. 677-715, jul./ago.1964.

Four systems of policy, politics, and choice. Public Administration Review. New York, v. 32, p. 298-310, jul./ago. 1972.

MARQUES, Eduardo. Os mecanismos relacionais. Revista Brasileira de Ciências Sociais. São Paulo, v. 14 n. 41, p. 45-67, out. 1999.

. Notas críticas à literatura sobre Estado, políticas estatais e atores políticos. Revista Brasileira de Informação Bibliográfica em Ciências Sociais, Rio de Janeiro, n. 43, p. 67102, jan. / dez. 1997.

MAUÉS, Olgaíses. A política de avaliação da educação superior e os desafios da implementação do Sinaes. In: REUNIÃO ANUAL DA ANPED, 30. 2007. Anais Eletrônicos... Disponível em: $<$ http://www.anped.org.br/app/webroot/reunioes/30ra/>. Acesso em: 23 maio. 2012. 
MELLO, Guiomar Namo de. Políticas públicas de educação. Estudos Avançados, São Paulo, v. 5, n.13, p. 7-47, set./dez. 1991.

MENEGHEL, Stela; ROBL, Fabiane; SILVA, Tatiana. A relação entre avaliação e regulação na Educação Superior: elementos para o debate. Educar. Curitiba, n. 28, p. 89-106, 2006.

MINAYO, Maria Cecília de Souza. Construção de indicadores qualitativos para avaliação de mudanças. Revista Brasileira de Educação Médica. Rio de Janeiro, v. 33, n.1, Suplemento 1, p. 83-91, 2009.

. O desafio do conhecimento: pesquisa qualitativa em saúde. 13. ed. São Paulo: Hucitec Editora, 2013. 407p.

MOROSINI, Marília Costa. Qualidade da educação universitária: isomorfismo, diversidade e equidade. Interface, Botucatu, v. 5, n. 9, p. 89-102, 2001.

Qualidade na educação superior: tendências do século. Est. Aval. Educ. São Paulo, v. 20, n. 43, p. 165-186, maio/ago. 2009.

MULLER, Pierre. Las políticas públicas. Bogotá: Universidad Externado de Colombia, 2002, 200 p.

.; SUREL, Yves. A análise das políticas públicas. Pelotas: Educat, 2002. 156p.

NEDER, Maria Lucia. Avaliação na educação a distância: significações para definição de percursos. In: PRETI, Oreste (Org.). Educação a Distância: inícios e indícios de um percurso. Cuiabá: UFMT/NEAD/IE, 1996. p. 75-91.

OCDE. Goverance in transition: public management reforms in OECD countries. Paris: Organization for Economic Co-operation and Development. 1995, 171 p.

. Building a high-quality teaching profession: lessons from around the world. Paris: OECD Publishing, 2011, 65 p.

OLIVEIRA, Ana Paula Matos et al. Políticas de avaliação e regulação da educação superior brasileira: percepções de coordenadores de licenciaturas no Distrito Federal. Avaliação (Campinas), Sorocaba, v. 18, n. 3, p. 629-655, nov. 2013.

OLIVEIRA-CASTRO, Gardênia. Um modelo integrado de avaliação do impacto do treinamento: IMPACT. 1999. 262 f. Tese (Doutorado em Psicologia) - Instituto de Psicologia, Universidade de Brasília, Brasília, 1999.

OLIVEIRA, Dalila Andrade et al.Transformações na organização do processo de trabalho docente e o sofrimento do professor. Rede Estrado. [200-?] Disponível em: <http://www.redeestrado.org/web/archivos/publicaciones/10.pdf >. Acesso em: 3 dez. 2014. 
PANTOJA, Maria Julia; LIMA, Suzana Maria. B.; BORGES-ANDRADE, Jairo Eduardo. Avaliação de impacto de treinamento na área de reabilitação: preditores individuais e situacionais. Revista de Administração, São Paulo, v. 36, n. 2, p.46-56, abr./jun. 2001.

PEREIRA. Júlio Emílio Diniz. As licenciaturas e as novas políticas educacionais para a formação docente. Educação \& Sociedade, Campinas, v. 20, n. 68, p. 109-125, dez. 1999.

PIMENTA, Selma Garrido; FRANCO, Maria Amélia Santoro; LIBÂNEO, José Carlos. Pedagogia, formação de professores - e agora? Problemas decorrentes das diretrizes curriculares nacionais para os cursos de pedagogia. In: DALBEN, Ângela Imaculada Loureiro de Freitas et al. (Orgs.). Convergências e tensões no campo da formação e do trabalho docente, Belo Horizonte: Autêntica, 2010. p. 831-852 (Didática e prática de ensino).

POLIDORI, Marlis Morosini. Políticas de avaliação da educação superior brasileira: provão, Sinaes, IDD, CPC, IGC e... outros índices. Avaliação, Campinas, v. 14, n. 2, p. 267-290, jul. 2009.

PORTAL da Transparência: permite que o cidadão acompanhe como o dinheiro público está sendo utilizado e ajude a fiscalizar. Disponível em: 〈http://www.portaltransparencia.gov.br〉. Acesso em: 13 dez. 2012.

RAGO, Luzia Margareth; MOREIRA, Eduardo. O que é taylorismo. São Paulo: Brasiliense, 1984. p. 7-55. (Coleção Primeiros Passos, n. 112)

RIOS, Terezinha. Compreender e ensinar: por uma docência da melhor qualidade. 8. ed. São Paulo: Cortez, 2010. 158p.

RISTOFF, Dilvo; GIOLO, Jaime. O Sinaes como sistema. Revista Brasileira de PósGraduação, Brasília, v. 3, n. 6, p. 193-213, dez. 2006.

ROCHA, Carlos Vasconcelos. Neoinstitucionalismo como modelo de análise para as políticas públicas: Algumas observações. Civitas. Porto Alegre, v. 5, n. 1, p. 11-28, jan./jun. 2005.

RODRIGUES, Viviane Aparecida; PEIXOTO, Maria do Carmo de Lacerda. Enade: considerações sobre o primeiro ciclo de avaliação dos estudantes de graduação em uma universidade federal. In: REUNIÃO ANUAL DA ANPED, 32. 2009. Anais Eletrônicos... Disponível em: < http://www.anped.org.br/app/webroot/reunioes/32ra/>. Acesso em: 23 maio. 2012.

RODRIGUES, Marli de Fátima; KUENZER, Acácia Zeneida. As diretrizes curriculares para o curso de pedagogia: uma expressão da epistemologia da prática. Olhar de professor, Ponta Grossa, v. 10, n. 1, p. 35-62, 2007.

RUA, Maria das Graças. Desmistificando o problema: uma rápida introdução ao estudo dos indicadores. Brasília: Escola Nacional de Administração Pública, Brasília, 2004. 
SACRISTÁN, José Gimeno. Tendências investigativas na formação de professores. In: PIMENTA, Selma Garrido; GHEDIN, Evandro (Orgs.). Professor reflexivo no Brasil: gênese e crítica de um conceito. São Paulo: Cortez, 2008. p. 81-87.

SÁNCHEZ, Rebecca M.; GUTIERREZ-GOMEZ, Cathy Calidad en la formación de docentes: enseñanza para la diversidad en la era de la estandarización. In: FLORES, Etelvina Sandoval; BLUM-MARTINEZ, Rebecca; ANDREWS, Ian Harold. (Orgs.). Desafíos y posibilidades en la formación de maestros. Una perspectiva desde América del Norte / Etelvina Sandoval Flores. México: UPN, 2009. p. 137-155.

SCHEIBE, Leda; AGUIAR, Márcia Ângela. Formação de profissionais da educação no Brasil: o curso de pedagogia em questão. Educação \& Sociedade, ano XX, n. 68, dez.1999, p. 220-238.

SCHEIBE, Leda. Diretrizes curriculares para o curso de pedagogia: trajetória longa e inconclusa. Cadernos de Pesquisa. 2007, v. 37, n.130, p. 43-62.

SCHÖN, Donald. Educando o profissional reflexivo: um novo design para o ensino e a aprendizagem. Porto Alegre: Artmed, 2000. 256p. (tradução: Roberto Cataldo Costa)

SCRIVEN, Michael. The methodology of evaluation. In: TYLER, Ralph; GAGNE, Robert; SCRIVEN, Michel. Perspectives of curriculum evaluation. Chicago: Rand McNally and Company, 1967. p. 39- 83. (Aera Monograph Series on Curriculum Evaluation).

SGUISSARDI, Valdemar. A avaliação defensiva no "modelo Capes de avaliação" - É possível conciliar avaliação educativa com processos de regulação e controle do Estado? Perspectiva, Florianópolis, v. 24, n. 1, p. 49-88, jan./jun. 2006.

SKOCPOL, Theda. Bringing the State back in: Strategies of analysis in current research. In: EVANS, P.; RUESCHMEYER, D.; SCOKPOL, T. Bringing the state back in. Cambridge: Cambridge University Press, 2002 (edição eletrônica).

SILVA, Maria Abádia da. Qualidade social da educação pública: algumas aproximações. Cadernos Cedes, Campinas, v. 29, n. 78, p. 216-226, maio/ago. 2009.

SOBRAL, Fernanda A. da Fonseca. Educação para a competitividade ou para a cidadania social? Perspectiva, São Paulo, v. 14, n.1, p. 3-11, jan./mar. 2000.

SOLIGO, Valdecir. Indicadores: conceito e complexidade do mensurar em estudos de fenômenos sociais. Estudos em Avaliação Educacional, São Paulo, v. 23, n. 52, p. 12-25, mai./ago. 2012.

SOUSA, José Vieira de. O ensino superior privado no Distrito Federal: uma análise de sua recente expansão: 1995-2001. 2003. 293 f. Tese (Doutorado em Sociologia) - Universidade de Brasília, Brasília, 2003. 
Restrição do público e estímulo à iniciativa privada: tendência histórica no ensino superior brasileiro. In: SILVA, Maria Abádia da; SILVA, Ronalda A. (Orgs.). A idéia de universidade: rumos e desafios. Brasília: Líber Livro, 2006, p. 139-178.

Qualidade na educação superior: lugar e sentido na relação público-privado.

Cadernos Cedes, Campinas, v. 29, n. 78, p. 242-256, maio/ago. 2009.

Educação superior no Distrito Federal: consensos, conflitos e transformações na configuração de um campo. Brasília: Líber Livro, 2013 (Coleção Políticas Públicas de Educação).

SOUZA, Celina. Políticas públicas: uma revisão da literatura. Sociologias, Porto Alegre, ano 8, n. 16, p. 20-45, jul./dez. 2006

SOUZA, Valdinei Costa. Qualidade dos cursos de pedagogia: sinais do Enade sobre a base docente. In: REUNIÃO ANUAL DA ANPED, 36. 2013. Anais Eletrônicos... Disponível em: < http://www.anped.org.br/app/webroot/reunioes/36ra/>. Acesso em: 23 fev. 2014.

Política de formação de professores para a educação básica: a questão da

igualdade. Revista Brasileira de Educação, Rio de Janeiro, v. 19, n. 58, p. 629-653, jul./set. 2014.

STREBEL, Paul. Breakpoints: como as empresas exploram mudanças radicais nos negócios. São Paulo: Atlas, 1993. 249 p.

UNESCO. Declaração mundial sobre educação para todos: satisfação das necessidades básicas de aprendizagem. Jomtien, 1990. Disponível em:

<http://unesdoc.unesco.org/images/0008/000862/086291por.pdf>. Acesso em: 16 jun.2010.

Declaração de Nova Delhi sobre educação para todos. Nova Dehli, 6 de dezembro de 1993. Disponível em: <http://unesdoc.unesco.org/images/0013/001393/139393por.pdf〉. Acesso em: 16 jun.2012

Educação para todos - O compromisso de Dakar. Dakar, Senegal, 2000.

Disponível em: <http://unesdoc.unesco.org/images/0012/001275/127509porb.pdf>. Acesso em: 16 jun.2012.

VARGAS, Miramar. Treinamento e desenvolvimento: reflexões sobre os seus métodos. Revista de Administração, São Paulo, v. 31, n. 2, p.126-136, abr./jun. 1996.

VERHINE, Robert; DANTAS, Lys. O Enade: reflexões a partir da completude do ciclo 2004 - 2006. In: SEMINÁRIO INTERNACIONAL DE AVALIAÇÃO DA EDUCAÇÃO

SUPERIOR, 1. 2008, Brasília. Anais Eletrônicos... Brasília: MEC, 2008. Disponível em: $<$ http://portal.mec.gov.br/index.php?option=com_content\&view=article\&id=15305 :seminario-internacional-de-avaliacao-da-educacao-superior-2008\&catid=323: orgaosvinculados\&Itemid=1075> . Acesso em: 24 maio. 2012. 
WERKEMA, Maria Cristina Catarino. As ferramentas da qualidade no gerenciamento de processos. Belo Horizonte: Fundação Christiano Ottoni; Escola de Engenharia da UFMG, 1995. 128 p. (Série Ferramentas da Qualidade).

ZARIFIAN, Philippe. A gestão da e pela competência. In: SEMINÁRIO INTERNACIONAL EDUCAÇÃO PROFISSIONAL, TRABALHO E COMPETÊNCIAS, 1. Rio de Janeiro, 1996. Anais... Rio de Janeiro: Centro Internacional para a Educação, Trabalho e Transferência de Tecnologia, 1996. $9 \mathrm{f}$. 
APÊNDICE A - Justificativa da escolha do método de pesquisa

Esta pesquisa teve como foco investigar a relação estabelecida entre os critérios de qualidade existentes na oferta de licenciaturas presenciais em pedagogia do Parfor e aqueles utilizados pelo Sinaes para avaliar esse tipo de curso. Adicionalmente, evidências teóricoempíricas apontaram que, subjacente a essa relação, delineou-se (de fato) uma Política de Qualidade para a Formação Inicial de Professores da Educação Infantil e dos Anos Iniciais do Ensino Fundamental (Política de Qualidade), estabelecendo de forma não planejada um padrão de qualidade para os cursos em questão.

Apesar de a relação investigada, tomada de forma isolada, ser aparentemente capaz de produzir conhecimento sobre indicadores e parâmetros de qualidade para cursos de pedagogia, entendeu-se que limitar o produto desta pesquisa a uma realidade fragmentada não seria relevante. Nesse sentido, identificou-se como desafio escolher um método que desse suporte epistemológico ao diálogo entre a manifestação explícita e a latente do fenômeno investigado, oferecendo as bases para a sua análise. Para tanto, optou-se por discutir a escolha do método da pesquisa, inserindo essa discussão no contexto mais amplo das mudanças pelas quais o mundo vem passando desde o final do século passado e que vem apresentando novos fundamentos para as análises dos fenômenos sociais.

Em Castells (1999), obteve-se uma descrição de como o atual ambiente social tem sido marcado por uma compressão da noção de espaço-tempo, em função das novas tecnologias de gestão, transporte, informação e comunicação. De acordo com o autor, a comunicação instantânea nas redes sociais via computador e celular, entre outras, aliadas ao o barateamento e velocidade dos meios de transporte foram responsáveis pelo movimento que tem deixado o mundo cada vez mais integrado. Em linhas gerais, as fronteiras e os limites impostos pela distância às interações entre as pessoas, à conexão de fatos e à repercussão de movimentos econômicos, políticos e sociais foram redimensionadas e diminuídas. Com isso, pôde-se considerar que tem havido uma aparente transição do comportamento humano de uma perspectiva analógica para a digital, desafiando análises sociais em ambientes multitarefa, inclusive aquela desenvolvida nesta pesquisa.

Além disso, no campo político-ideológico, a queda do muro de Berlim em 1989 marcou o fim de um período caracterizado pela Guerra Fria entre americanos e soviéticos, a qual polarizou o mundo entre dois extremos. O breve século XX, analisado por Hobsbawm (1995), trouxe muitas lutas étnico-religiosas e disputas econômicas que ainda hoje não foram solucionadas. Por outro lado, aparentemente despertou a humanidade para a possibilidade de 
reconciliação de ideais e valores antagônicos em uma perspectiva de terceira via ${ }^{79}$ (GIDDENS, 1999), nem melhor nem pior que as tradicionais vertentes socialista e liberal, apenas distinta por não polarizar as diferenças, mas, sim, por reconciliar propostas de desenvolvimento econômico-social.

Considerando essa realidade complexa e em plena construção, procurou-se no método de pesquisa, as bases para a construção de um conhecimento relevante e confiável. Conforme orientou Gatti (2001, p. 80), “o conhecimento advindo das pesquisas parece ter necessidade de carregar em si certo tipo de abrangência, nível de consistência e foco de impacto, aderência ao real, tocando em pontos críticos concretos". Nesse processo, a discussão sobre o método de investigação e a sua inserção no debate do problema de estudo, bem como na construção da pergunta de pesquisa e da busca por sua resposta, evidenciaram a necessidade de uma reflexão sobre o conflito das perspectivas epistemológicas entre as ciências sociais e as ciências naturais.

Conforme asseverou Santos (1989), as discussões sobre a separação entre as perspectivas de fazer ciências se refletem na ruptura entre o homem e a natureza, a partir da qual decorrem outras como aquelas entre sujeito/objeto; singular/universal; mental/material; valor/fato; público/privado, quantitativo/qualitativo etc. Numa redução do pensamento do autor, foi possível associar às ciências que estudam a natureza a análise de sistemas fechados, cuja estrutura de relação entre os elementos caracterizam-se mais prontamente pela linearidade, seguindo uma lógica que pode ser identificada como constante. Já as que estudam as relações sociais estão mais próximas aos fenômenos que se constrói e se reconstrói a cada momento, exigindo do pesquisador mais sensibilidade em relação a essa menor constância, independentemente do caráter provisório ou evolucionista do conhecimento científico.

Sobre as possíveis visões de ciência que refletem no método científico, Gatti (2001) analisou a discussão travada na área de educação durante a década de 1980. Nessa época, pesquisadores analisavam questões teórico-metodológicas e ressaltavam contraposição entre posturas epistemológicas, métodos e técnicas que fazem parte do processo de investigação científica, desembocando na dicotomia, oposição ou polarização entre modelos quantitativos e qualitativos. A autora ressaltou, porém, que [...]

79 Corrente socialdemocrática defendida por Antony Giddens, sociólogo inglês que ganhou projeção por ter influenciado o governo do trabalhista Tony Blair na Inglaterra e inspirado outros ao redor do mundo, como os governos dos presidentes Luís Inácio Lula da Silva (2003-2010) e Dilma Rousseff (2011-). Posicionada entre liberais e socialistas, essa corrente tenta reconciliar uma política econômica conservadora e uma política social progressista. 
[...] os conceitos de quantidade e qualidade não são totalmente dissociados, na medida em que de um lado a quantidade é uma interpretação, uma tradução, um significado que é atribuído à grandeza com que um fenômeno se manifesta (portanto é uma qualificação dessa grandeza) e, de outro, ela precisa ser interpretada qualitativamente, pois sem relação a algum referencial não tem significação em si (GATTI, 2001, p. 74).

Desse argumento, decorreu o entendimento de que aspectos inicialmente colocados como dicotômicos, polarizados ou contraditórios podem guardar outras relações que não só a exclusão mútua. Assim, ao se refletir sobre o método de pesquisa, procurou-se a particularidade e o contexto do estudo, de forma a ser possível ponderar e fazer escolhas sobre caminhos, crenças, possibilidades de análises e concepções de ciência.

Tal reflexão teve aderência à realidade trazida pelo objeto pesquisado uma vez que aspectos inerentes à formação do pedagogo foram mais comumente encontrados na literatura de forma distinta ou em oposição, tais como: a) acumulação do capital x educação de qualidade; b) racionalidades de formação do professor para a sociedade do século XXI: técnica $\mathrm{x}$ prática $\mathrm{x}$ crítica $^{80}$; c) diretrizes legais para a proposta curricular do curso de pedagogia $\mathrm{x}$ instrumentos de medidas do Sinaes $\mathrm{x}$ concepções de qualidade dos cursos nas IES; d) pedagogo especialista $\mathrm{x}$ pedagogo professor; e) avaliação formativa $\mathrm{x}$ avaliação somativa, entre outros. Por outro lado, esses mesmos aspectos que parecem se contradizer, por vezes, assumem uma perspectiva complementar ou, até mesmo, de reciprocidade, ampliando a compreensão e interpretação da questão em estudo. Nesse sentido, entendeu-se que reforçar contradições poderia levar a polarizações e que tais polarizações poderiam encobrir a totalidade das relações existentes entre os elementos do fenômeno.

Assumiu-se, então, a necessidade de escolher um método de investigação que fosse capaz de viabilizar a discussão dessas relações complexas, bem como o movimento entre o entendido e o subentendido identificado no objeto de pesquisa, dentro do contexto social ideologicamente menos dicotômico. Entre os caminhos possíveis, encontrou-se no hiperempirismo dialético (ou realismo dialético) proposto por Gurvitch (1987), uma estrutura conceitual que pareceu contribuir com a proposta deste estudo de captar e analisar argumentos apresentados como excludentes, sem compromisso de ratificá-los como tal.

Conforme asseverou Gurvitch (1987), para que o movimento da realidade seja analisado sem reducionismos e simplificação excessiva, deve-se observar a possibilidade da ocorrência dos procedimentos operatórios que a dialética permite. Segundo o autor, não é a simples contradição, buscada em relações polarizadas dos fenômenos humanos, que garante o

${ }^{80}$ As discussões teóricas que embasam esses conceitos foram encontradas principalmente em Araújo (2009). 
estudo do movimento dialético real. Conforme seguiu afirmando, as análises da realidade por meio de relações permanentemente contraditórias, ao contrário de captar o referido movimento, podem engessá-las/mumificá-las ${ }^{81}$. Como alternativa, propôs o uso de cinco procedimentos operatórios para realizar essas análises, a saber:

a) complementaridade dialética: sinalizando que a contrariedade entre elementos pode ser só aparente, podendo ser desvelada pela simples junção de aspectos diversos de um mesmo fenômeno que o caracterizam em sua totalidade, pela compensação (posições intermediárias de características opostas), ou pelo encaixe de aspectos que se completam, hora em uma direção, hora em direção contrária;

b) implicação dialética múltipla: sinalizando interseções e pontos de afinidade entre elementos contrários;

c) ambiguidade dialética: expressando a validade de aspectos ambíguos do fenômeno social, tendo em vista a própria natureza humana;

d) polarização dialética: expressando contradições entre elementos do fenômeno, cujo método hiperempirista dialético tende a analisar por meio das demais relações dialéticas consideradas;

e) reciprocidade de perspectivas: sinalizando que alguns aspectos de um fenômeno não admitem separação ou categorização, fazendo parte de uma totalidade.

Para Gurvitch (1987), a liberdade humana e a sua capacidade de fazer a história impede que posições definitivas sejam adotadas em torno dos fenômenos sociais. Por isso, propôs manter o olhar crítico sobre a realidade, considerando sempre o homem como o elemento chave dos fenômenos sociais e o pivô do seu movimento e dinamismo. Em síntese, assumiu que os fenômenos humanos são tão complexos quanto a própria natureza do seu agente criador, sugerindo que o exercício de investigar a realidade social se abra a todas as suas possibilidades de organização.

No entanto, Gurvitch (1987) advertiu que a sua proposta de análise da realidade, como qualquer outra tentativa de se analisar os fenômenos em sua totalidade, "nada mais faz do que preparar os quadros para a explicação" (p. 210). Ressaltou que o método proposto não é capaz, por si só, de explicar um fenômeno por meio de causalidade singular ou leis. Em linhas gerais, seu propósito foi identificar e analisar o fenômeno, preparando as bases para uma explicação sobre os motivos que o fazem se comportar, naquele contexto, de uma forma e não de outra.

\footnotetext{
${ }^{81}$ Linguagem figurada utilizada por Gurvitch (1987) numa alusão àquilo que é fixo, não se move.
} 
Conforme destacou Schwartzman (1964), não cabem no sistema analítico proposto por Gurvitch instrumentos que poderiam ser englobados como de análise multivariacional ${ }^{82}$, que reduzem o campo sociológico a um espaço de variáveis no qual se busca estabelecer a harmonia entre a realidade empírica e as hipóteses teóricas previamente levantadas. O próprio autor do hiperempirismo dialético admitiu isso ao recusar, de certa forma, a redução dos fenômenos sociais a um simples conjunto de variáveis, desconectado do contexto que faz parte.

Por outro lado, ainda conforme Schwartzman (1964), as análises que envolvem variáveis permitem o exame sistemático e a proposição de possibilidades lógicas de combinação entre elas. Para tanto, limitam tais possibilidades através proposições que decorrem da teoria (hipóteses), as quais são testadas empiricamente com análises de tipo estatístico. Nesse processo, as análises oferecem bases para a intersubjetividade no trabalho cientifico, para a acumulação de conhecimentos e para reformulações ou ampliações teóricas.

Diante desse argumento, encontrou-se nas ideias de Gurvitch (1987) a defesa de um exercício constante de olhar ao mesmo tempo para o fenômeno como uma totalidade, e para o conjunto de elementos que o constitui como sistemas menores, formados por outros elementos que possuem a sua própria totalidade sistêmica. Em síntese, o hiperempirismo dialético, em vez de polarizar em relação às análises multivariacionais destacadas por Schwartzman (1964), pareceu complementá-las, desafiando-as a abrirem-se ao improvável, a analisarem criticamente a estabilidade, bem como a demolirem artificialidades, parcialidades e cristalizações decorrentes de uma visão reduzida da realidade.

A perspectiva dialética em foco aparentemente não negou o dado captado operacionalmente na realidade empírica (reduzida a um conjunto de variáveis ou aspectos passíveis de serem medidos), mas propôs um olhar mais abrangente no desenvolvimento do estudo, que implicou detalhar e descrever a realidade de forma a ampliar as possibilidades de resposta à questão de pesquisa, abrindo-se às possíveis alternativas que os dados podem trazer. Conforme destacou Cánovas (1997), o sistema de Gurvitch é de integração de elementos que são, em si mesmos, sistemas ou totalidades. Com isso, o hiperempirismo dialético inspirou nesse trabalho a tentativa de evitar simplificações e reducionismos, mesmo ante a necessidade de "recortar" a realidade para estudo. De certa forma, esse método propôs

\footnotetext{
${ }^{82}$ O conceito de análise multivariacional não foi definido por Schwartzman (1964), tendo sido considerado nesta análise como aquelas que envolvem as relações entre três ou mais variáveis (conceitos utilizados para captar a realidade de uma forma aproximada, operacionalizando conceitos abstratos, a partir de características concretas que variam conforme a realidade se apresente).
} 
que o elemento ou parte estudada fosse encarado como um fenômeno social total, desafiando a análise às possibilidades dialéticas a ele inerentes.

Dessa forma, a tentativa de uso dos princípios do hiperempirismo dialético nesta pesquisa pretendeu contemplar a análise da realidade em movimento - explicitada a partir do objeto, interpretada pelo sujeito e compreendida na relação sujeito e objeto - questionando simplificações arbitrárias e verdades que desconsideram a totalidade ou a inserção das partes no todo. Foi com base nessa orientação epistemológica que se buscou desenvolver as análises sobre a relação que se estabelece entre os critérios de qualidade assumidos pelo Parfor na oferta de cursos de pedagogia e aqueles presentes nas avaliações do Sinaes nas desse tipo de curso, bem como nos demais movimentos subjacentes a ela.

Por fim, emergiu desta justificativa de escolha do hiperempirismo dialético como orientação epistemológica da pesquisa, a questão da importância acadêmica do seu autor. A busca da produção dos autores brasileiros que se referenciam nas obras de Georges Gurvitch, permitiu localizar notadamente no campo do direito (sociologia jurídica) a principal influência de seu pensamento em pesquisas recentes - tese da pluralidade nas fontes do direito de forma a não contrapor o direito positivo e o normativo, mas a considerá-los como parte de uma realidade total. Como lembrou Jean-Christophe (2001), apesar de Gurvitch poder ser considerado como uma referência para os interessados em sociologia no período do póssegunda grande guerra, há que se reconhecer que ele foi relegado a certo esquecimento nesse campo, notadamente após sua morte na década de 1960.

Também é dessa década as discussões feitas por Schwartzman (1964) sobre a marginalidade do pensamento de Georges Gurvitch, atestada, segundo ele, pela falta de referências a esse autor na literatura sociológica internacional, além da sua ausência ou influência em publicações tão importantes como os Archives Européennes de Sociologie ou a Revue Française de Sociologie. Como explicações para essa situação, Schwartzman (1964) apontou: (i) a opção epistemológica da moderna sociologia científica de adotar "teorias de alcance médio", enquanto a proposta de Gurvitch era a elaboração de sistemas globais; (ii) a perspectiva do autor em considerar a ciência social como distinta das ciências naturais, enquanto a sociologia moderna tende a considerar que epistemologicamente ambas são iguais e devem partilhar do mesmo status; e (iii) o fato de que, nas ideias de Gurvitch, a filosofia da liberdade é extremamente cara fazendo com que elas entrem em conflito direto com os postulados da sociologia científica, a qual busca expressar o conhecimento por meio de leis ou relações [imutáveis] entre variáveis, enquanto o autor em foco entendia que os fenômenos 
sociais são determinados pela história e que a realidade social está em permanente transformação.

Nesse sentido, para Schwartzman (1964, não paginado) [...]

[...] a sociologia gurvitchiana pode se dar ao luxo, assim, de pretender ser ao mesmo tempo suficientemente científica para despir-se dos dogmatismos e simplificações inerentes a toda ideologia que tenha vigência social, e suficientemente geral e globalizante para satisfazer às necessidades de sistema de seus adeptos. A consequência, entretanto, é que ela se torna demasiado científica para os que necessitam de uma ideologia, e demasiado ideológica para quem busca ciência.

Outra maneira de colocar as divergências entre uma orientação como a de Gurvitch e as de tipo científico, ou empiricista, é que a primeira seria mais histórica, mais adequada à apreensão das estruturas concretas, enquanto que a segunda trabalharia somente com aspectos isolados, parciais, abstratos, dos fenômenos humanos, e, assim, jamais conseguiria "morder" suficientemente o real. Ainda mais que a sociologia científica trabalharia na busca de fenômenos estáticos, invariantes, enquanto que Gurvitch introduziria, muito mais ricamente, a dimensão de tempo e movimento, dada a sua preocupação dialética.

Desse entendimento, depreendeu-se que Schwartzman (1964) não negou que muitos pensadores sociais, preocupados com a formulação de "leis" gerais sobre o comportamento social, negligenciam a necessidade de contextualização do fenômeno estudado. Todavia, destacou que a real contextualização do fenômeno só seria possível quando a ele se aplicassem uma série de conhecimentos parciais, com características de abstração e intemporalidade. Tal conclusão do autor, embora dentro de uma perspectiva de contestação às ideias de Gurvitch, em verdade, pareceram esclarecer a proposta hiperempirista, na medida em que reforçou o estudo das partes do fenômeno para se chegar ao todo, enquanto Gurvitch assumiu que o todo é mais do que a simples soma das partes.

Por fim, se reconheceu que a proposta de aproximação entre perspectivas polarizadas que permeia o sistema proposto por Gurvitch é de difícil compreensão em um mundo quase sempre dividido entre dois lados: qualitativo x quantitativo; liberal x socialista; burguês $\mathrm{x}$ proletário; ideologia x ciência; público x privado etc. Inclusive, essa falta de defesa de um dos lados da "realidade" talvez seja o ponto que justifique o esquecimento do autor. No entanto, ao gosto hiperempirista, a não aceitação da existência de uma realidade estática, simplória e dual e por consequência, da defesa de apenas um dos lados, pode ser também o motivo para justificar o resgate de suas ideias. No caso desta pesquisa, assumiu-se essa segunda opção.

\section{Referências}

CÁNOVAS, Cecilio Nieto. Gurvitch (1894-1965). Madrid: Ediciones Del Orto.1997, 93 p. (Coleção: Biblioteca Filosófica). 
CASTELLS, Manuel. A sociedade em rede. A era da informação: economia, sociedade cultura; v.1. São Paulo: Paz e Terra, 1999. 617 p.

GATTI, Bernardete A. Implicações e Perspectivas da pesquisa educacional no Brasil contemporâneo. Cadernos de Pesquisa, São Paulo, n. 113, jul./2001, p. 65-81.

GIDDENS, Antony. A terceira via: reflexões sobre o impasse político atual e o futuro da social-democracia. Rio de Janeiro: Editora Record, 1999. 173 p.

GURVITCH, Georges. Dialética e sociologia. São Paulo: Vértice, 1987. 239 p.

HOBSBAWM, Eric, Era dos extremos: o breve século XX : 1914-1991. São Paulo:

Companhia das Letras, 1995. 598 p.

JEAN-CHRISTOPHE, Marcel. Georges Gurvitch: les raisons d'un succès. Cahiers internationaux de sociologie, 2001/1, n. 110, p. 97-119.

SANTOS, Boaventura de Sousa. Introdução a uma ciência pós-moderna. Rio de Janeiro, Graal, 1989.

SCHWARTZMAN, Simon. Introdução ao pensamento de Georges Gurvitch. (Introdução dezembro, 1964). Não paginado. Disponível em < http://www.schwartzman.org.br/simon/ gurvitch.htm>. Acesso em: 02 Dez. 2012 
APÊNDICE B - Carta de apresentação aos Coordenadores(as) do Curso de pedagogia do Parfor Presencial (amostra definitiva de pesquisa)

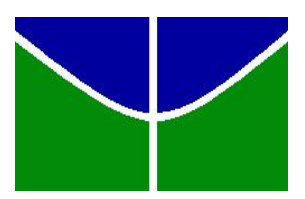

Brasília, XXXXXX.

Aos Srs.(as)

Coordenadores(as) do Curso de pedagogia do Parfor Presencial

Prezado(a) Senhor(a),

1. Apresentamos a V. Sa. Valdinei Costa Souza, aluna regularmente matriculada no curso de doutorado do Programa de Pós-Graduação em Educação da Universidade de Brasília.

2. Atualmente, essa aluna está realizando coleta de dados para sua pesquisa que tem por objetivo analisar a Política de Qualidade para a Formação Inicial de Docentes da Educação Infantil e dos anos Iniciais do Ensino Fundamental no Brasil, sob o ângulo das relações que se estabelecem entre os critérios de qualidade assumidos pelo Parfor na oferta e pelo Sinaes na avaliação de licenciaturas presenciais de pedagogia.

3. Em função desta proposta, o curso do Parfor Presencial coordenado por V. Sa. foi escolhido de forma aleatória, sendo de fundamental importância entrevistá-lo para discutir aspectos sobre a repercussão dos resultados divulgados pelo Sistema Nacional de Avaliação da Educação Superior (Sinaes) nesse curso, bem como as características de qualidade assumidas por ele na sua estruturação. Dessa forma, solicitamos a sua colaboração no sentido de conceder, aproximadamente, 40 (quarenta) minutos de sua agenda de trabalho para a realização da entrevista.

4.

Adiantamos que todos os dados fornecidos serão confidenciais, e que nenhum participante será identificado em qualquer comunicação ou publicação futura. Todavia, os resultados da pesquisa serão colocados à disposição dos interessados, tão logo o trabalho esteja concluído.

5. Ressaltando a importância de sua contribuição para o estudo, agradecemos antecipadamente e colocamo-nos à disposição para quaisquer esclarecimentos.

Atenciosamente,

\author{
Professor Dr. José Vieira de Sousa \\ Orientador \\ Matrícula UnB XXXXXX \\ Telefone: XXXXXX
}



APÊNDICE C - Termo de consentimento livre e esclarecido (Coordenador)

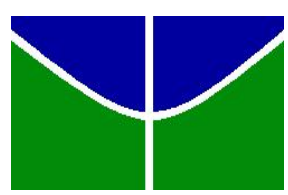

TERMO DE CONSENTIMENTO LIVRE E ESCLARECIDO

\author{
Autora da pesquisa: Valdinei Costa Souza Matrícula XXXXXX \\ Doutoranda do Programa de Pós-Graduação em Educação/UnB
}

$\mathrm{Eu}$, interlocutor(a)

da pesquisa abaixo assinado, declaro que fui informado(a), de forma clara e objetiva, acerca da pesquisa de doutorado que tem por objetivo analisar a Política de Qualidade para a Formação Inicial de Docentes da Educação Infantil e dos anos Iniciais do Ensino Fundamental no Brasil, sob o ângulo das relações que se estabelecem entre os critérios de qualidade assumidos pelo Parfor na oferta e pelo Sinaes na avaliação de licenciaturas presenciais de pedagogia. Afirmo que tenho pleno conhecimento de que, nessa pesquisa, serão realizados, além dessa entrevista, os seguintes procedimentos de coleta de dados: análise de possíveis relatórios, indicadores e conceitos divulgados pelo Sistema Nacional de Avaliação da Educação Superior (Sinaes) sobre o curso vinculado ao Plano Nacional de Formação de Professores, modalidade presencial, que eu coordeno. Estou ciente de que não é obrigatória a minha participação nesse estudo, caso me sinta constrangido(a), antes ou durante a realização do trabalho, e de que os materiais utilizados para a coleta das informações serão destruídos após o registro dos dados. Declaro que tenho ciência de que a pesquisadora manterá em caráter confidencial todas as respostas que comprometam a minha privacidade e que tenho conhecimento de que, caso solicite, receberei informações atualizadas durante o estudo, ainda que isto possa afetar a minha vontade de continuar dele participando. Por isso, autorizo a gravação da entrevista e sua utilização para a pesquisa, desde que minha identidade permaneça resguardada e não seja utilizada em prejuízo da(s) pessoa(s) envolvida(s) e/ou da instituição.

Declaro, ainda, que me foi esclarecido(a) que essas informações poderão ser obtidas por intermédio de Valdinei Costa Souza (telefone $\mathbf{X X X X X X}$ ou do e-mail $\mathbf{X X X X X X}$ ) e que o resultado da pesquisa somente será divulgado com objetivo científico-acadêmico, mantendose em sigilo a minha identidade e meu vínculo institucional. Por fim, afirmo estar ciente de que a minha participação nesse estudo é voluntária e poderei desistir a qualquer momento, não havendo previsão de gastos ou remuneração. E por estar de pleno acordo com os termos ajustados e mencionados neste documento, assino o presente instrumento em duas (duas) vias de igual teor e forma, para um só efeito.

de de

\title{
Interlocutor(a) da pesquisa
}

Valdinei Costa Souza

Responsável pela pesquisa 

APÊNDICE D - Roteiro definitivo de entrevista

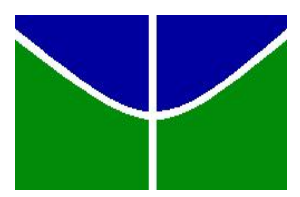

\section{I - APRESENTAÇÃO}

-Agradecimento pela concessão da entrevista.

-Orientação sobre o TERMO DE CONSENTIMENTO LIVRE E ESCLARECIDO

-Informação sobre o objeto da pesquisa: relações entre Parfor e Sinaes em torno dos critérios de qualidade assumidos pelos Programas para a oferta e avaliação de cursos presenciais de pedagogia

\section{II - DADOS DO(A) COORDENADOR(A)}

i. Tempo na função:

ii. Tempo de trabalho na IES:

iii. Maior título de formação acadêmica:
a. Área:
b. Ano de obtenção:
c. Instituição:
d. Informações adicionais sobre a formação acadêmica (caso não seja na área de educação):

iv. Síntese da experiência profissional em cursos de Pedagogia

v. Síntese da experiência profissional em relação ao Sinaes:

\section{III - DADOS DO CURSO}

vi. Trajetória recente do projeto pedagógico do curso até fazer parte do Parfor Presencial:

vii. Aspectos institucionais das turmas do Parfor Presencial em relação às demais:

viii. Identificação do curso nos resultados divulgados pelo Sinaes (MUNICÍPIO E NOTA): 


\section{IV - PERGUNTAS}

BLOCO 1 - A qualidade assumida pelo curso na formação de professores da educação infantil e dos anos iniciais do ensino fundamental

1. Quais os principais aspectos que ilustram a qualidade do curso coordenado por você?

2. A seguir, citarei alguns aspectos da qualidade da dimensão organização didáticopedagógica. Por favor, analise a qualidade do curso sob sua coordenação em relação a eles

a) Diferenças entre o projeto pedagógico das turma(s) oferecidas pelo Parfor, em relação ao curso regular.

b) Perfil do pedagogo formado na(s) turma(s) do Parfor.

c) Conteúdos disciplinares para atender ao perfil do egresso do Parfor.

d) Estágio curricular na(s) turma(s) do Parfor

e) Atividades complementares

3. Agradeceria se o(a) senhor(a) sintetizasse a concepção de formação assumida pelo curso para a profissionalização o professor da educação básica.

4. Em sua compreensão, de que forma os embates em torno da formação do docente e do especialista em educação afetam a política de formação de professores?

BLOCO 2 - Concepção de qualidade e repercussões da avaliação da educação superior na oferta do curso

5. Para o senhor(a), de uma forma geral, o que é qualidade da educação superior?

6. Hoje, no Brasil, quando se fala sobre qualidade da educação superior o que isso significa?

7. Como os resultados do Enade de pedagogia e da avaliação de cursos têm sido usados nesse curso?

8. Segundo sua compreensão, quais são os principais usos dos resultados das avaliações realizadas pelo Sinaes na instituição como um todo?

9. Existe algum comentário que você gostaria de fazer a respeito do que foi tratado nesta entrevista? 
APÊNDICE E - Solicitação de dados ao Inep

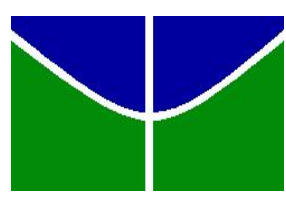

Brasília, 18 de setembro de 2013.

Ilma. Sra. XXXXXXXXX

Diretora de Avaliação da Educação Superior (DAES)

Instituto Nacional de Estudos e Pesquisa Educacionais Anísio Teixeira (Inep)

Prezada Senhora,

1. Sou Valdinei Costa Souza, aluna regularmente matriculada no curso de doutorado do Programa de Pós-Graduação em Educação da Universidade de Brasília, desenvolvendo a pesquisa "QUALIDADE NA EDUCAÇÃO SUPERIOR: perspectivas e desafios na avaliação dos cursos presenciais de pedagogia do Parfor à luz da vertente regulatória do Sinaes" (título provisório), sob a orientação do Prof. Dr. José Vieira de Sousa.

2. A pesquisa tem por objetivo analisar a Política de Qualidade para a Formação Inicial de Docentes da Educação Infantil e dos anos Iniciais do Ensino Fundamental no Brasil, sob o ângulo das relações que se estabelecem entre os critérios de qualidade assumidos pelo Parfor na oferta e pelo Sinaes na avaliação de licenciaturas presenciais de pedagogia.

3. Em função desta proposta, solicitamos a disponibilização dos relatórios de avaliação "in loco" das instituições listadas no Anexo A. Os dados serão tratados de forma sigilosa e atenderão exclusivamente aos propósitos da referida pesquisa de doutoramento. Nesse sentido, adiantamos que todos os dados fornecidos serão confidenciais, e que nenhuma instituição será identificada em qualquer comunicação ou publicação futura.

Atenciosamente,

\author{
Valdinei Costa Souza \\ Matrícula Doutorado em Educação/UnB XXXXXX \\ Endereço: $\mathbf{X X X X X X}$ \\ E-mail: $\mathbf{X X X X X X}$ \\ Tels. XXXXXX
}



APÊNDICE F - Pré-teste do roteiro piloto de entrevista

O pré-teste do roteiro de entrevista aplicado no estudo de campo teve como objetivo analisar a capacidade de o instrumento proposto oferecer respostas à pergunta de pesquisa. Nesse sentido, verificou se os itens que o compuseram atendiam às diretrizes de análise explicitadas e às categorias analíticas levantadas, bem como se estavam livres de questões ambíguas, ou ainda, que resultassem em constrangimentos para os respondentes.

Para tanto, procurou-se respeitar as discussões e balizamentos teóricos adotados, ao mesmo tempo que não se desejou fixá-los como ponto de chegada, mas apenas garanti-los como ponto de partida. Dentro desta perspectiva, esse processo não se assemelhou àqueles usualmente presentes em pesquisas quantitativas de validar a capacidade de o instrumento mensurar a realidade por meio de processos estatísticos: valeu-se prioritariamente de uma análise sobre a possibilidade de as respostas obtidas por ele oferecer uma perspectiva de análise hermenêutica da realidade.

\section{Coleta de dados para o pré-teste}

A versão piloto do roteiro de entrevista dos coordenadores (Apêndice $H$ ) foi construída a partir do referencial teórico presente neste estudo. Ela se constituiu de 08 perguntas abertas, formuladas para atender às definições preliminares de diretrizes e respectivas categorias de análise da pesquisa. Todas as questões guardaram relação com as construções teóricas realizadas, exceção feita à de número 8, que serviu apenas ao propósito de captar alguma sugestão dos entrevistados ou aspecto não contemplado nas questões anteriores, conforme expressado na Tabela A.

Tabela A - Correspondência entre as diretrizes e categorias de análise e o roteiro piloto de entrevista

\begin{tabular}{l|l|c}
\hline \multicolumn{1}{c}{ Diretrizes de análise } & \multicolumn{1}{c}{ Categorias analíticas } & Id. Questões \\
\hline $\begin{array}{l}\text { (Não)ações, omissões e embates da Política de } \\
\text { Qualidade. }\end{array}$ & Avaliação da educação superior & 4 \\
\cline { 2 - 2 } $\begin{array}{l}\text { Critérios de qualidade para a oferta e regulação } \\
\text { dos cursos de pedagogia. }\end{array}$ & Base docente & 7 \\
\cline { 2 - 2 } $\begin{array}{l}\text { Conceito e concepções de qualidade na educação } \\
\text { superior. }\end{array}$ & Corpo Docente & \\
\cline { 2 - 3 } & Infraestrutura & \\
\cline { 2 - 3 } & Conceito de qualidade & 1 \\
\hline
\end{tabular}

Fonte: Elaboração da autora com base na versão piloto do roteiro de entrevista.

$\mathrm{Na}$ Tabela A, as diretrizes de análise representam as tessituras teóricas construídas na primeira parte da pesquisa. Já as categorias analíticas, conforme orientado por Minayo (2013), 
procurou destacar os principais conceitos advindos da referida construção teórica. Essas categorias se materializaram nas ideias centrais e nas posturas a serem buscadas na análise dos dados empíricos, sem desconsiderar que outras categorias, identificadas como empíricas, poderiam emergir dessa análise piloto. Observou-se, então, se os itens do roteiro para préteste de entrevista seriam capazes de gerar interconexões entre as categorias analíticas e empíricas, reservando o processo de interpretação dos dados para aqueles que seriam posteriormente coletados pelo roteiro definitivo.

Esse roteiro piloto foi aplicado em uma amostra de coordenadores, selecionada com base nos seguintes critérios intencionais: representação de cada uma das dependências administrativas consideradas (estadual, federal e privada); presença das duas regiões onde estão mais concentrados os cursos (Nordeste e Sudeste); diferentes unidades da federação; e, concordância do coordenador em participar da entrevista. De acordo com Babbie (1995), escolher intencionalmente uma amostra é popular, fácil e oferece baixo custo, adequando-se à proposta de pré-teste do instrumento de coleta. Por isso, como base nesses critérios foram entrevistados três coordenadores de cursos de pedagogia do Parfor, sendo dois da região Nordeste - um de IES federal e outro de IES estadual - e um coordenador da região Sudeste de IES privada.

A aplicação do instrumento piloto de entrevista foi realizada com os coordenadores de forma remota, por meio de conferência web. Na realização dessas entrevistas, alguns cuidados formais foram observados para manter uma relação amistosa e de confiança com o entrevistado, quais sejam: apresentação formal da pesquisadora, da sua vinculação institucional com a UnB e a Capes, bem como da proposta da pesquisa e dos motivos da escolha do entrevistado. Procurou-se, ainda, empreender uma conversa inicial reforçando as informações sobre a pesquisa e a pesquisadora, além de se garantir o esclarecimento de dúvidas, o anonimato sobre os dados informados. Tais cuidados foram formalizados por meio de termo de consentimento livre e esclarecido (Apêndice C).

\section{Análise Piloto (pré-teste)}

Seguindo o quadro de correspondência disposto anteriormente na Tabela A, buscou-se discutir se os dados levantados pelas questões do roteiro piloto permitiam realizar as discussões sugeridas pelas diretrizes de análise. Inicialmente, foram analisados os dados levantados pelas questões 1,2 e 3 frente à diretriz que analisou a qualidade da educação 
superior. Tendo como referência essa diretriz, esperava-se que os dados permitissem discutir temas como: avaliação, critérios de qualidade e regulação da educação superior. Havia, ainda, a expectativa de que as questões pudessem levar os entrevistados a analisar o uso dos resultados proporcionados pelos resultados das avaliações do Sinaes no contexto do curso, da IES e do Parfor.

Em relação à questão 1, todos os entrevistaram analisaram a qualidade do curso sob sua responsabilidade e não a concepção de qualidade da educação superior. Embora a questão buscasse uma "concepção" de qualidade de uma forma geral, aparentemente, por ser a primeira questão e o contexto da entrevista favorecesse a discussão sobre a realidade do curso, os coordenadores participantes do piloto entenderam o questionamento a partir do seu curso, de uma forma restrita. Um deles declarou expressamente que falaria da qualidade do seu curso e completou que "todas [as alunas e mais um único aluno do sexo masculino] falam muito bem [do que era oferecido]" (Entrevistado 3, piloto). Dessa forma, ao contrário do que se esperava, a questão 1 não trouxe como resposta uma concepção de qualidade da educação superior, mas sim aspectos específicos da qualidade do curso, repetindo o foco de outras questões do roteiro. Além disso, essa experiência implicou numa reorganização dos itens na versão definitiva, partindo-se primeiro da realidade do curso, para depois discutir o conceito de qualidade de uma forma mais geral.

Em relação às questões 2 e 3 do instrumento piloto, houve uma adequação entre as respostas oferecidas pelos entrevistados e os dados necessários à discussão dos usos dos resultados da avaliação cursos de pedagogia. Na sequência, passou-se a observar a possibilidade das questões 5 e 6 atenderem a discussão sobre os critérios de qualidade para a oferta e regulação dos cursos de pedagogia.

Em relação à questão 5, o termo "a serem trabalhados", que remeteria a uma questão propositiva, de autoanálise frente a uma concepção mais ampla de critérios de qualidade, foi apropriada pelos respondentes como se tivesse sido utilizada a palavra "trabalhados". Além disso, as respostas à questão 5 foram muito próximas àquelas trazidas pela questão 6, sugerindo a necessidade de uma nova estrutura para o item em análise.

No que se referiu especificamente à questão 6, o detalhamento na alíneas "b" e "c" pareceu ter reforçado os aspectos positivos, já declarados sobre a qualificação do corpo docente do curso e da estrutura de salas e laboratórios, levantados pela questão 5, ao passo que, no item "a", os aspectos didático-pedagógicos discutidos na literatura - que poderiam evidenciar diferenças ou similaridades na oferta do curso - tiveram pouco espaço de aprofundamento. 
Por fim, considerou-se as condições das questões 4 e 7 , do roteiro dos coordenadores oferecerem subsídios para discutir as (não)ações, omissões e embates da Política de Qualidade. Observou-se que:

- A questão 4 propôs discutir as finalidades da avaliação da educação superior. Porém, apenas um dos coordenadores assumiu essa linha na sua resposta, enquanto outro disse que era pessimista em relação à avaliação e que o resultado dela não reflete a qualidade do curso, tendo afirmado, inclusive, que a avaliação de nada serve, apesar de anteriormente ter expressado haver algum tipo de reflexão institucional sobre seus resultados. O terceiro coordenador confundiu a avaliação institucional com a avaliação da aprendizagem na educação superior. Tais resultados alertaram sobre a pertinência de se buscar embates conceituais de formulação da política, na realidade empírica do coordenador de curso.

- A questão 7 reforçou novamente a preocupação de se buscar os embates conceituais que permearam a emergência da Política de Qualidade no contexto do curso: com exceção de uma das coordenadoras que acompanhou o processo de aprovação das DCN da licenciatura em pedagogia, as demais respostas indicam que o conceito "base docente" não está devidamente esclarecido, passando longe da sua proposta de formação do pedagogo para superar a dicotomia entre o perfil do egresso entre o professor e o especialista em educação. Entretanto, como tal questão foi bastante discutida teoricamente e afeta diretamente a forma de organização dos cursos do Parfor, procurou-se explicitar melhor seu significado dentro da discussão dos critérios de qualidade do curso.

Adicionalmente, considerou-se que as questões 4 e 7 centraram-se na tentativa de capturar embates em torno da finalidade da avaliação e da base docente sem, no entanto, ter sinalizações empíricas de que tais embates se reverteram em pontos de disputa no âmbito do Parfor, como os foram, respectivamente, no âmbito do Sinaes e das DCN da licenciatura em pedagogia. Nesse sentido, insistiu-se na discussão da base docente e dos propósitos avaliativos, respectivamente, como aspecto de qualidade dos cursos do Parfor e da própria concepção de qualidade e usos dos resultados avaliativos. Não se fechou as portas para que tais embates pudessem emergir das entrevistas dos coordenadores do Parfor, mas passou-se a considerar que tais dados seriam mais claros nas Atas das reuniões do CTC-EB, o que permitiria discutir melhor a diretriz de análise em foco. 
Assim, tomando-se os resultados apresentados pela aplicação piloto dos instrumentos do estudo de campo, os roteiros de entrevistas definitivos foram reelaborados, conforme sistematizado na Tabela B.

Tabela B - Correspondência entre questões do instrumento definitivo de coleta de dados do estudo de campo e abordagem teórica da pesquisa

\begin{tabular}{l|l|c}
\hline \multicolumn{1}{c|}{ Diretrizes de análise } & \multicolumn{1}{c}{ Categorias analíticas } & \multirow{2}{*}{ Id. Questões } \\
\hline \multirow{2}{*}{$\begin{array}{l}\text { (Não) ações, omissões e embates da Política de } \\
\text { Qualidade }\end{array}$} & Embates & - \\
\cline { 2 - 3 } & (Não) ações & - \\
\cline { 2 - 2 } $\begin{array}{l}\text { Critérios de qualidade para oferta e regulação dos } \\
\text { cursos de pedagogia }\end{array}$ & Organização didático-pedagógica & \multirow{2}{*}{$1,2,3$ e 4} \\
\cline { 2 - 3 } & Corpo Docente & 5,6 \\
\cline { 2 - 3 } $\begin{array}{l}\text { Conceito e Concepções de qualidade na educação } \\
\text { superior }\end{array}$ & Infraestrutura & 7,8 \\
\cline { 2 - 3 } & Uso dos resultados da avaliação & 5 \\
\hline
\end{tabular}

Fonte: Elaboração da autora com base na versão definitiva do roteiro de entrevista

O roteiro final, como produto do pré-teste do roteiro de entrevista, foi disponibilizado no Apêndice D deste trabalho, tendo atendido aos propósitos e discussões orientadas pela pergunta de pesquisa, conforme resultados apresentados neste relatório. 

APÊNDICE G - Coleta piloto de dados: Carta de apresentação aos coordenadores curso de pedagogia Parfor Presencial

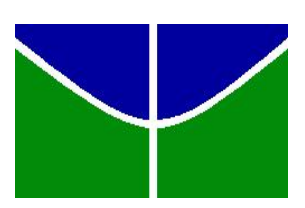

Brasília, 24 de julho de 2013.

Aos Srs.(as)

Coordenadores(as) do Curso de pedagogia do Parfor Presencial

Prezado(a) Senhor(a),

1. Apresentamos a V. Sa. Valdinei Costa Souza, aluna regularmente matriculada no curso de doutorado do Programa de Pós-Graduação em Educação da Universidade de Brasília.

2. Atualmente, essa aluna está realizando teste no instrumento de coleta de dados para sua pesquisa que tem por objetivo analisar a Política de Qualidade para a Formação Inicial de Docentes para a Educação Infantil e Anos Iniciais do Ensino Fundamental no Brasil, sob o ângulo das relações que se estabelecem entre os critérios de qualidade assumidos pelo Parfor na oferta e pelo Sinaes na avaliação de licenciaturas presenciais de pedagogia.

3. Em função desta proposta, o curso do Parfor Presencial coordenado por V. Sa. foi escolhido de forma aleatória, sendo de fundamental importância entrevistar-lhe para discutir aspectos sobre a repercussão dos resultados divulgados pelo Sistema Nacional de Avaliação da Educação Superior (Sinaes) nesse curso, bem como as características de qualidade assumidas por ele na sua estruturação. Dessa forma, solicitamos a sua colaboração no sentido de conceder, aproximadamente, 40 (quarenta) minutos de sua agenda de trabalho para a realização da entrevista.

4. Adiantamos que todos os dados fornecidos serão confidenciais, e que nenhum participante será identificado em qualquer comunicação ou publicação futura. Todavia, os resultados da pesquisa serão colocados à disposição dos interessados, tão logo o trabalho esteja concluído.

5. Ressaltando a importância de sua contribuição para o estudo, agradecemos antecipadamente e colocamo-nos à disposição para quaisquer esclarecimentos.

Atenciosamente,

\author{
Professor Dr. José Vieira de Sousa \\ Orientador \\ Matrícula UnB xxxxx \\ Telefone: $\mathrm{xxxxx}$
}



APÊNDICE H - Instrumentos piloto de coleta de dados

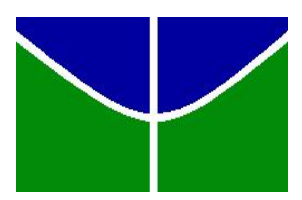

\section{I - APRESENTAÇÃO}

1. Agradecimento pela concessão da entrevista.

2. Orientação sobre o TERMO DE CONSENTIMENTO LIVRE E ESCLARECIDO

3. Informação sobre o objeto da pesquisa: relações entre Parfor e Sinaes em torno dos critérios de qualidade assumidos pelos Programas para a oferta e avaliação de cursos presenciais de pedagogia

\section{II - DADOS DO(A) COORDENADOR(A)}

i. Tempo na função:

ii. Tempo de trabalho na IES:

iii. Maior título de formação acadêmica:
a. Área:
b. Ano de obtenção:
c. Instituição:
d. Informações adicionais sobre a formação acadêmica (caso não seja na área de educação):

iv. Síntese da experiência profissional em cursos de Pedagogia

v. Síntese da experiência profissional em relação ao Sinaes:

\section{III - DADOS DO CURSO}

vi. Trajetória recente do projeto pedagógico do curso até fazer parte do Parfor Presencial:

vii. Aspectos institucionais das turmas do Parfor Presencial em relação às demais:

viii. Código do curso no MEC: 


\section{IV - PERGUNTAS}

BLOCO 1 - Repercussões da avaliação de qualidade da educação superior na oferta do curso

1. Como coordenador(a) de um curso pertencente ao Parfor Presencial, como você concebe a qualidade da educação superior no Brasil?

2. Como os resultados do Enade de pedagogia e da avaliação de cursos têm sido usados nesse curso?

3. Segundo sua compreensão, quais são os principais usos dos resultados das avaliações realizadas pelo Sinaes na instituição como um todo?

4. Em sua opinião, a avaliação da educação superior no Brasil visa atender quais finalidades?

BLOCO 2 - A qualidade assumida pelo curso na formação de professores da educação infantil e dos anos iniciais do ensino fundamental

5. Em sua compreensão, quais são os principais critérios a serem trabalhados visando à qualidade do curso sob sua coordenação?

6. Como o(a) senhor(a) situa a qualidade do curso sob sua coordenação em relação aos seguintes elementos?

6.1 Organização didático pedagógica (perfil do pedagogo, distribuição dos conteúdos na proposta curricular do curso, estágio curricular etc.)

6.4 Perfil do corpo docente

6.5 Infraestrutura

6.6. Outros elementos que julgue relevantes

7. De que forma a base docente definida pelas DCN da licenciatura em pedagogia está sendo atendida no projeto pedagógico desse curso?

8. Existe algum comentário que você gostaria de fazer a respeito do que foi tratado nesta entrevista? 
APÊNDICE I - Plano de Trabalho (Doutorado Sanduíche)

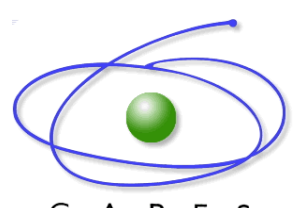

C A P E S

\title{
PROGRAMA INSTITUCIONAL DE DESENVOLVIMENTO DE RECURSOS HUMANOS (PIDRH/Capes)
}

\author{
ESTÁGIO DE DOUTORADO
}

Critérios de qualidade para cursos de pedagogia: uma análise das avaliações in loco do Sinaes

\section{Identificação}

Valdinei Costa Souza

Curso: Doutorado em Educação (matrícula UnB: xx/xxxxxxx)

Analista em Ciência e Tecnologia/Capes (matrícula Siape: xxxxxxx)

\section{Instituição de origem}

Universidade de Brasília

Programa de Pós-Graduação em Educação

Linha de Pesquisa Políticas Públicas e Gestão da Educação

Orientador: Prof. Dr. José Vieira de Sousa

\section{Instituição de destino}

Fundação Carlos Chagas

Departamento de Pesquisas Educacionais

Linha de Pesquisa Políticas e Práticas da Educação Básica e Formação de Professores

Orientadora do estágio: Profa. Dra. Bernardete Angelina Gatti

\section{Breve contextualização da pesquisa na qual se insere o estágio}

A pesquisa de doutoramento que está sendo desenvolvida assume que o Plano Nacional de Formação de Professores da Educação Básica (Parfor) e o Sistema Nacional de Avaliação da Educação Superior (Sinaes) ao contribuírem, respectivamente, para a oferta com qualidade de cursos de licenciatura e para subsidiar a sua regulação parecem emergir como uma espécie de síntese em prol da adequada formação inicial de professores da educação básica brasileira. Por outro lado, apesar da concepção de qualidade das licenciaturas assumida pelo Parfor e pelo Sinaes ter no seu centro as orientações emanadas das Diretrizes Curriculares Nacionais (DCN), os princípios que garantem a convergência entre essas concepções de qualidade não estão claros. Entre outros fatores que podem concorrer para o descompasso entre tais concepções, pode-se citar: i) que o conceito de qualidade é polissêmico e pode fazer emergir vários significados ou entendimentos, conforme a realidade de cada Programa; ii) que existem cursos do Parfor que não são legalmente obrigados a participar do Sinaes, uma vez que não 
fazem parte do Sistema Federal de Ensino Superior; iii) que o Sinaes privilegia aspectos gerais de qualidade entre as áreas de conhecimento para a elaboração dos seus instrumentos e critérios de avaliação, remetendo parâmetros específicos da qualidade em cada área de curso às respectivas DCN; e iv) que o sentido de orientação geral das DCN pode não ser capaz de regular conteúdos específicos da formação do aluno-professor que podem interessar diretamente ao Parfor.

Observando esse quadro, identificou-se como relevante analisar a política de qualidade para a formação inicial de docentes para a educação básica no Brasil, a partir da seguinte pergunta norteadora: que relação se estabelece entre os critérios de qualidade utilizados pelo Sinaes para subsidiar a regulação dos cursos de pedagogia e aqueles assumidos pelo Parfor na oferta de licenciaturas presenciais para a formação de professores da educação infantil e dos anos iniciais do ensino fundamental?

Para responder a essa pergunta de pesquisa, estabeleceu-se como objetivo geral analisar a política de qualidade para a formação inicial de docentes para a educação infantil e anos iniciais do ensino fundamental no Brasil, sob o ângulo das relações que se estabelecem entre os critérios de qualidade assumidos pelo Parfor na oferta e pelo Sinaes na avaliação de licenciaturas presenciais de pedagogia.

Para o alcance desse objetivo geral, foram definidos os seguintes objetivos específicos:

1. Analisar como os embates de concepções sobre a avaliação e regulação da educação superior e sobre a base docente apresentam-se no contexto dos cursos presenciais de pedagogia do Parfor.

2. Analisar o uso dos resultados aferidos pelo Sinaes sobre sua qualidade pelos cursos presenciais de pedagogia do Parfor.

3. Comparar os critérios de qualidade assumidos pelos cursos presenciais de pedagogia do Parfor na sua estruturação com os indicadores de qualidade utilizados pelo Sinaes para avaliá-los.

Para tanto, o processo de coleta de dados considerará a realização de:

a) Estudo de campo: aplicação de roteiro semiestruturado de entrevista a uma amostra de coordenadores de pedagogia no Parfor Presencial.

b) Pesquisa documental: relatórios e documentos divulgados pelo Sinaes sobre a qualidade desses cursos investigados; atas das reuniões do Conselho Técnico Científico da Educação Básica da Capes (CTC-EB).

Porém, para a realização das análises previstas nos objetivos específicos, dever-se-á identificar os critérios de qualidade do Sinaes presentes no instrumento de avaliação in loco. 
Tais critérios não estão previamente definidos, nem na literatura, nem na legislação, sendo necessário um estudo prévio para identificar como as DCN de pedagogia se materializam nas avaliações realizadas. Esta lacuna constitui-se, pois, no cerne da justificativa para a presente proposta de estágio de doutorado.

\section{Objetivo do estágio}

Analisar os critérios de qualidade do Sinaes para avaliar in loco os cursos de pedagogia, considerando a base docente, as concepções de formação de professores e as DCN das licenciaturas.

\section{Justificativa para a escolha da instituição de destino}

Produção acadêmica consolidada e relevante no campo das políticas públicas de formação de professores que oferece o suporte complementar necessário ao desenvolvimento da tese de doutorado.

\section{Descrição das atividades a serem desenvolvidas}

A - Planejamento do trabalho: levantamento dos dados, identificação da base teórica, definição metodológica da análise;

B - identificação dos critérios de qualidade do Sinaes para avaliação de cursos de pedagogia;

C - identificação das perspectivas teóricas em que estão embasados esses critérios;

D - análise da convergência dos critérios com os documentos legais;

E - análise dos limites e potencialidades do instrumento utilizado pelo Sinaes para avaliar a qualidade dos cursos de pedagogia.

Para a realização dessas atividades, prevê-se a necessidade de realização de cinco encontros presenciais a serem distribuídos durante os meses previstos para o desenvolvimento do estágio.

\section{Período do estágio}

Início: 12 de agosto de 2013

Fim: 12 de fevereiro de 2014 



\section{APÊNDICE J - Relatório de Atividades (Doutorado Sanduíche)}

\section{F. Fundeģäc Carlos chagas}

Como parte do processo para obtenção do título de Doutor em Educação no Programa de PósGraduação em Educação da Universidade de Brasília, realizou-se estágio de doutorado (sanduiche) na Fundação Carlos Chagas, no período de 12/08/2013 a 12/02/2014. Nesse estágio, sob orientação da Profa. Dra. Bernardete Angelina Gatti, buscou-se analisar os critérios de qualidade do Sinaes para avaliar in loco os cursos de pedagogia. Para tanto, ocorreram quatro encontros mensais, a seguir sintetizados:

Primeiro Encontro: 02/09/2013. Objetivo: realizar planejamento das atividades de pesquisa/DOUTORADO SANDUICHE

1. Agendamento das datas dos próximos encontros.

2. Discussão teórica/metodológica do estudo a ser realizado

3. Discussão da população de pesquisa

4. Definição da estrutura da primeira etapa da pesquisa, identificada como marco teórico preliminar para a análise dos dados.

5. Definição da amostra de pesquisa e anuência para início da coleta dos dados.

6. Definição do envio de versão do marco teórico preliminar até dois dias antes do próximo encontro presencial previsto.

Segundo Encontro: 09/10/2013 -11/10/2013. Objetivo: discutir o primeiro documento contendo o marco teórico da pesquisa.

1. Comentários e orientações sobre o marco teórico da pesquisa proposta.

2. Indicações de referências bibliográficas que precisarão ser analisadas.

3. Planejamento das atividades a serem desenvolvidas durante o mês: ajustes/complementação do marco teórico e coleta de dados.

4. Definição do envio da 2. ${ }^{\text {a }}$ versão do marco teórico, ampliando com procedimentos metodológicos, até dois dias antes do próximo encontro presencial previsto.

Terceiro Encontro: 04/11/2013. Objetivo: discutir o segundo documento contendo o marco teórico e metodológico da pesquisa

1. Comentários e orientações sobre a 2. ${ }^{a}$ versão do marco teórico-metodológico.

2. Orientações metodológicas sobre coleta e tratamento dos dados.

3. Discussão inicial sobre as categorias para análise dos dados.

4. Envio da versão preliminar do relatório final, com ajustes indicados e análise preliminar de dados.

Quarto Encontro 16/12/2013. Objetivo: discutir o terceiro documento contendo análise de dados e ajustes solicitados na parte teórica.

1. Comentários e orientações sobre a versão preliminar do relatório final.

2. Discussão sobre a análise de dados.

3. Encaminhamentos para o fechamento do Estágio: envio por correio eletrônico da versão definitiva do relatório final.

4. Após a análise foi exarado parecer entregue à Capes para a conclusão o Estágio de Doutorado (sanduíche). 